\title{
A REPREZENTÁCIÓVÁLTÁS MINT PROBLÉMAMEGOLDÁSI STRATÉGIA TANÍTHATÓSÁGÁRÓL
}

Doktori (Ph.D.) értekezés

\author{
NAGY ÖRS
}

Témavezető

Dr. KosZTOLÁNYi JÓZSEF

egyetemi docens

MatematikA- És SzÁmítástudománYok DokTORI Iskola

Szegedi Tudományegyetem

TERMÉSZETTUDOMÁNYI ÉS INFORMATIKAI KAR

Bolyai INTÉZET

2017

SZEGED 


\section{Tartalomjegyzék}

Jelmagyarázat $\quad 3$

1. Bevezetés 4

1.1. A témaválasztás indoklása . . . . . . . . . . . . . . . . 4

1.2. A kutatás célja . . . . . . . . . . . . . . . . . . 5 5

2. A kutatás elméleti háttere $\quad 6$

2.1. A matematikatanítás célrendszere . . . . . . . . . . . . . . 6

2.2. A problémamegoldó gondolkodás . . . . . . . . . . . . . . . . 7

2.3. A matematikai gondolkodás természete . . . . . . . . . . . . . . 11

2.4. A problémamegoldó képesség fejlesztése . . . . . . . . . . . . . . . 15

2.5. Kutatási elözmények . . . . . . . . . . . . . . . . . . 17

3. A kutatás anyaga és módszere $\quad 19$

3.1. Az elömérés . . . . . . . . . . . . . . . . . . . . . . . . 19

3.1.1. Az előteszt célja . . . . . . . . . . . . . . . . . . . . . . . 19

3.1.2. Az előmérés módszere . . . . . . . . . . . . . . . . . 20

3.1.3. A feladatok megoldása és értékelése . . . . . . . . . . . . . . . . 20

3.2. A fejlesztés céljai és módszere . . . . . . . . . . . . . . . . . . 30

3.2.1. A fejlesztés céljai . . . . . . . . . . . . . . . . 30

3.2.2. A fejlesztés módszere . . . . . . . . . . . . . . . . . 31

4. A fejlesztés folyamata és értékelése 32

4.1. Algebrai problémák geometriai reprezentációi . . . . . . . . . . . . . . 33

4.1.1. Szintetikus geometria . . . . . . . . . . . . . . 33

4.1.2. Koordinátageometria . . . . . . . . . . . . . . . 50

4.1.3. Trigonometria . . . . . . . . . . . . . . . 70

4.2. Geometriai problémák - algebrai eszközök . . . . . . . . . . . . 76

4.2.1. A Descartes-féle koordináta-rendszer felhasználása . . . . . . . . . . 76

4.2.2. A Gauss-féle komplex számsík alkalmazása . . . . . . . . . . . . . . 84

4.3. Alkalmas függvény keresése . . . . . . . . . . . . . . . . . . . . 98

4.3.1. Elemi függvények tulajdonságainak felhasználása . . . . . . . . . . 98

4.3.2. A matematikai analízis elemeinek alkalmazása . . . . . . . . . . . . 110 
5. Az utómérés anyaga és értékelése $\quad 119$

5.1. A mérés célja és módszere . . . . . . . . . . . . . . . . . . . . . . 119

5.2. A feladatok megoldása és értékelése . . . . . . . . . . . . . . . . . . . 119

5.3. A mérések statisztikai összehasonlítása . . . . . . . . . . . . . . . 125

6. Végkövetkeztetések 128

6.1. A hipotézisek igazolása . . . . . . . . . . . . . . . . . . . . . 128

6.2. Továbblépési lehetöségek . . . . . . . . . . . . . . . . . . . . . 129

Köszönetnyilvánítás $\quad 130$

$\begin{array}{ll}\text { Összefoglalás } & 131\end{array}$

$\begin{array}{ll}\text { Summary } & 137\end{array}$

$\begin{array}{ll}\text { Irodalomjegyzék } & 142\end{array}$

$\begin{array}{ll}\text { Publikációs jegyzék } & 146\end{array}$ 


\section{Jelmagyarázat}

\begin{tabular}{|c|c|}
\hline Szimbólum & Jelentése, neve \\
\hline $\mathbb{N}$ & Természetes számok halmaza \\
\hline $\mathbb{N}^{*}$ & Pozitív természetes számok halmaza \\
\hline $\mathbb{Z}$ & Egész számok halmaza \\
\hline $\mathbb{Z}_{+}$ & Pozitív egész számok halmaza \\
\hline $\mathbb{Z}_{-}$ & Negatív egész számok halmaza \\
\hline $\mathbb{Q}$ & Racionális számok halmaza \\
\hline $\mathbb{Q}_{+}$ & Pozitív racionális számok halmaza \\
\hline $\mathbb{R}$ & Valós számok halmaza \\
\hline $\mathbb{R}_{+}$ & Pozitív valós számok halmaza \\
\hline $\mathbb{C}$ & Komplex számok halmaza \\
\hline $\mid$ & Abszolút érték; halmaz elemszáma; vektor hossza \\
\hline\|\| & Vektor normája \\
\hline [ ] & Egész rész \\
\hline\{\} & Törtrész \\
\hline$(;)$ & Nyílt intervallum; pont vagy vektor koordinátái \\
\hline$[;]$ & Zárt intervallum \\
\hline$[; ;)$ & Balról zárt, jobbról nyílt intervallum \\
\hline$(;]$ & Balról nyílt, jobbról zárt intervallum \\
\hline$\approx$ & Közelítőleg egyenlő \\
\hline$:=$ & Definíció egyenlőség \\
\hline$\equiv$ & Egybevágóság, kongruencia \\
\hline $\log _{a}$ & $a$ alapú logaritmus \\
\hline $\ln$ & Természetes (e alapú) logaritmus \\
\hline $\lg$ & Tízes alapú logaritmus \\
\hline$C_{n}^{k}$ & Binomiális együttható \\
\hline$f: A \rightarrow B$ & Függvény értelmezési tartománnyal és értékkészlettel \\
\hline $\operatorname{Im} f$ & Függvény képhalmaza: $\{f(x) \mid x \in A\}$ \\
\hline $\overrightarrow{A B}$ & $A B$ vektor \\
\hline$[A B]$ & $A B$ szakasz, mint ponthalmaz \\
\hline$A B$ & {$[A B]$ hossza vagy $A B$ egyenes } \\
\hline$d(P, e)$ & a $P$ pont távolsága az $e$ egyenestől \\
\hline $\begin{array}{l}m_{e} \\
{[A B C]}\end{array}$ & $\begin{array}{l}\text { az } e \text { egyenes iránytényezője, meredeksége } \\
A B C \text { törött vonal, mint ponthalmaz }\end{array}$ \\
\hline$\widehat{A B C}$ & $A B C$ szög, mint ponthalmaz \\
\hline$m(\widehat{A B C})$ & az $\widehat{A B C}$ mértéke \\
\hline$A B C_{\triangle}$ & ABC háromszög, mint ponthalmaz \\
\hline$K_{A B C_{\triangle}}$ & az ABC háromszög kerülete \\
\hline$s$ & háromszög félkerülete \\
\hline$T_{A B C_{\triangle}}$ & az ABC háromszög területe \\
\hline$m_{A B}$ & az $A B$ oldalhoz tartozó magasságvonal \\
\hline$s_{A B}$ & az $A B$ oldalhoz tartozó súlyvonal vagy oldalfelezö \\
\hline$C(O, r)$ & origó középpontú, egység sugarú kör \\
\hline
\end{tabular}




\section{1. fejezet}

\section{Bevezetés}

\subsection{A témaválasztás indoklása}

Heurisztikus problémamegoldási stratégiákról másodéves cserediákként Szegeden hallottam elöször. Noha a matematikatanítás legfontosabb célja a gondolkodásra nevelés, amely problémamegoldás és a matematika felfedeztető módon való tanításával valósítható meg, melynek elérésében óriási szerepet játszik az általános heurisztikus eljárások ismerete, a romániai közoktatásban az általános problémamegoldási eljárások explicit, de sajnos néha még implicit tanítása is meglehetősen háttérbe szorul. Ennek egyik fö oka minden bizonnyal a közismerten gyors tempójú, a tanulókat túlságosan korán absztrahálni kényszerítő általános román matematikatanítási hagyomány, amelyen változtatni a korábban szinte egyáltalán nem létező, ma már a matematika szaktantárgyak mellett föllelhető egyféléves Matematika tanításának módszertana kurzus, illetve a néhány éve beindított Matematikadidaktika mesterszak formájában éledező, de meglehetősen hiányos tanárképzés sem igazán képes.

Pólya György és Alan H. Schoenfeld munkáira akkori tanárom, későbbi témavezetőm, Kosztolányi József tanár úr hívta föl a figyelmemet. Pólya témába vágó alapműveit [25], [26], [27], majd Schoenfeld [29], [30] és Kosztolányi [17] kutatásainak eredményeit áttanulmányozva, érdekesnek tűnt egy hazai felmérés elvégzése, így kezdő középiskolai tanárként 10-11. osztályos tanulók problémamegoldási képességének felmérésébe, illetve fejlesztésébe kezdtem.

Kosztolányi egyetemi hallgatókkal végzett kutatásából kiderül, hogy egyes heurisztikák jobban, mások kevésbé fejleszthetők. Kevésbé, vagy legalábbis lassabban, nehezebben alakítható ki például a problémák különböző irányból való tudatos megközelítésének gondolata, a problémának az eredeti kontextustól eltérö, más területen való megoldása: például algebrai feladat geometriai úton való megoldása, vagy fordítva. Kosztolányi ezt azzal magyarázza, hogy a diákokban nagyon erős az algebrai problémák tipikus algoritmussal történő algebrai megoldásának reflexe, és ez elnyomja a vizuális problémareprezentáció, a grafikus megoldás gondolatát, stratégiai jellegü ötletét [17].

Egyrészt ez a megfigyelés sarkallt arra, hogy olyan problémák révén, amelyek sikeres megoldása az eredeti megfogalmazás kontextusától eltérő, más területeken való okoskodást igényel, a reprezentációváltás mint problémamegoldási stratégia taníthatóságával foglalkozzak. Másrészt úgy gondolom, hogy a matematika különböző területeinek együtt 
láttatása, összekapcsolása szemléletformáló hatással van a diákokra, ezért indokoltnak tartom úgy a tanórákon, mint szakkörökön szintetizáló jellegü problémák tárgyalását.

A diákoknak az első foglalkozássorozat alatt tanúsított érdeklődésén felbuzdulva, az azóta eltelt öt év során, lényegében azonos fejlesztési tananyaggal, hasonló jellegü szakköröket tartottam még két alkalommal: elöször ugyancsak 10-11. osztályos tanulóknak, majd II., illetve III. éves matematika szakos egyetemi hallgatóknak. Az eredeti mérések anyagát mindkét alkalommal meghagyva, a foglalkozások előtt és után, újra bemenő és kimenő méréseket végeztem.

\subsection{A kutatás célja}

Jelen dolgozatban a problémamegoldási folyamat elméleti megközelítései és a témába vágó korábbi kutatások áttekintése után, az általam végzett mérések összehasonlító elemzésével, illetve a mérések között lezajlott fejlesztő tevékenységsorozat bemutatásával foglalkozom.

A kutatás során a következő céljaim voltak:

1. a matematikai gondolkodás, problémamegoldás elméleti hátterének áttekintése

2. a diákok problémamegoldási képességének mérése; ezen belül hangsúlyosan:

- vizuális problémareprezentáció-készítési, elemzési és a problémamegoldási folyamatban való sikeres alkalmazási képesség mérése

- a transzformációelv mint általános heurisztikus eljárás alkalmazási képességének mérése

- tananyagrész-összekapcsoló, -szintetizáló képesség mérése

3. célzottan a fenti képességeket fejlesztő tananyag kidolgozása és alkalmazása

4. a fejlesztés elején fölállított hipotéziseim igazolása:

- megfelelő tananyaggal a diákok problémamegoldó képessége fejleszthető:

- a diákok tananyagrész-összekapcsoló, -szintetizáló képessége fejleszthető

- a diákok vizuális problémareprezentáció-készítési és transzformációelv alkalmazási képessége fejleszthető

- a problémamegoldási heurisztikák explicit tanítása révén a diákoknak a problémamegoldás során felhasználható eszköztára bővíthető 


\section{2. fejezet}

\section{A kutatás elméleti háttere}

\subsection{A matematikatanítás célrendszere}

A XX. század második felétől kezdődően fokozott érdeklődés mutatkozik a matematika tanításával és tanulásával foglalkozó kutatások iránt. Ezek egy része a tanítási tartalmakkal és módszerekkel, másik része a tanítás céljával foglalkozik.

A tantárgyi követelmények kidolgozásában jelentős elörelépést jelentett a minden tantárgy számára használható, Bloom [4] által kidolgozott taxonómia, amely a tanítási célok három vetületét különbözteti meg:

- kognitív (tudati) célok: ismeret, megértés, alkalmazás, elemzés (analízis), egybefogás (szintézis), értékelés

- affektív (érzelmi) célok: befogadás, válaszadás, értékek kialakítása, értékrendszer kialakítása, az értékrendszer belső jellemképző erővé alakítása - világnézet kialakítása

- pszichomotorikus (mozgásos) célok: utánzás, manipulálás, artikuláció, automatizálás

A Bloom-féle taxonómia alapján Zech [39] a matematikatanítás kognitív célrendszerét a következőképpen határozta meg:

- megértés

- tényállás ismerete

- tartalmi és formai eljárások birtoklása

- analízis (elemzés) és egyszerü alkalmazások

- szintézis (egybefogás) és önálló problémamegoldás

- értékelés

Jelen dolgozatban közvetlenül a tanulók szintetizáló- és önálló problémamegoldó képességének mérésével és fejlesztésével foglalkozom. E képesség aktív megléte természetesen feltételezi, és maga után vonja a többi terület birtoklását is. 
A 70-es évektől kezdve a figyelem a könnyen müveletesíthető kognitív célokról tudatosan az affektív területek felé is fordult. Egyre több kutatás foglalkozott a matematikához való hozzáállás, a matematika iránti érdeklődés, motiváltság és a matematika, mint tiszta, illetve alkalmazott tudomány értékelésének vizsgálatával.

Wittmann [37] a matematikatanítás következő affektív célrendszerét adja meg [3]:

- a matematika okozta öröm, érdeklődés és pozitív hozzáállás fejlesztése

- önbizalommal végzett önálló tanulói munka

- közös munkára való készség, abban való öröm lelése; másoknak adott segítség, másoktól való tanulás

- céltudatos, lelkes, koncentráltan végzett munka; törekvés a megértésre

- a matematikában szellemi ösztönzés és megelégedettség találása

- sikeres matematikai alkotómunka végén öröm és büszkeség érzése

- a matematika relevanciájának és harmóniájának felismerése, megértése; a társadalom által elfogadott értékelés méltányolása

- a matematikai fogalmak viszonylagos tisztaságának és a matematikai ismeretek viszonylagos bizonyosságának méltányolása, értékelése

- egy matematikai objektum, megfontolás, elv szépségének értékelése

A matematikatanításnak elsősorban az elemi szakaszában jelentősebb szerepet játszó, de a teljes oktatási, tanulási folyamatot befolyásoló pszichomotorikus céljai Ambrus [3] szerint a feladatok megoldásainak tiszta, világos, áttekinthető rögzítése, a körző, vonalzó és egyéb eszközök ügyes használata, szabadkézi rajz- és vázlatkészítés, modellek készítése, számoló- és számítógépek alkalmas kezelése.

\subsection{A problémamegoldó gondolkodás}

\section{A probléma fogalma}

Problémának nevezzük a szó legáltalánosabb értelmében azt a helyzetet, amelyben bizonyos célt el akarunk érni, de a cél elérésének útja számunkra ismeretlen [18].

A matematikaoktatásban probléma alatt olyan feladatot értünk, amely megoldásához szükséges eszköz ismeretlen, vagy több ismert eszköz újszerü kombinált alkalmazására van szükség, és ez nem nyilvánvaló a feladatmegoldó számára [5], [7]. Ugyanakkor, ha egy probléma megoldása gondot okoz valakinek, attól még ugyanaz a probléma egyszerünek, akár rutinfeladatnak tünhet egy másik embernek, tehát egy feladat probléma volta szubjektív jellegü. Evvel a relatív megközelítéssel egyezik Schoenfeld problémaértelmezése is, mely szerint az, hogy egy feladat probléma-e vagy sem, nem magának a feladatnak a lényegi sajátossága, sokkal inkább az egyén és a feladat közötti kapcsolat jellemzője. Ezt alátámasztják a diákok körében végzett korábbi kutatások [31], [17] és a jelenlegi kísérlet során szerzett tapasztalataim is. 


\section{A problémamegoldás folyamata}

Fisher [10] szerint a hatékony problémamegoldáshoz szükség van néhány alapvető készségre, illetve stratégiára. A legegyszerübb stratégia a Megértés-Tervezés-MegoldásÉrtékelés folyamata:

1. Megértés. Mindenekelőtt nagyon fontos a probléma megértése, saját szavakkal való megfogalmazása.

2. Tervezés. A végrehajtandó cselekvés megtervezése, amelyhez rendszerezett gondolkodásra van szükség. A tervezésben segít, ha a problémamegoldó rendelkezik bizonyos tapasztalattal hasonló típusú feladatokról, és sikerül felidézni legalább egyet és annak megoldását, vagy ha a problémamegoldó készíteni tud egy modellt a feladatról.

3. Megoldás. A probléma megoldása az előzetes terv alapján.

4. Értékelés. A probléma és a talált megoldás felülvizsgálata.

A problémamegoldás folyamatára vonatkozó javaslatait, útmutatásait Pólya [25] a következö négy fö csoportba osztotta:

1. A feladat megértése

2. Tervkészítés

3. Tervünk végrehajtása

4. A megoldás vizsgálata

\section{Heurisztikus eljárások}

Ugyanakkor Pólya [25] részletesen tárgyalja a problémamegoldási folyamat során különösen hasznos úgynevezett általános heurisztikákat. Ezek olyan eljárások, amelyek függetlenek a vizsgálódások konkrét tárgyától, és mindenféle feladatra alkalmazhatóak; céljuk a felfedezés és feltalálás módszereinek és szabályainak tanulmányozása. A heurisztikus stratégiák ismerete lényeges segítség a probléma megértése és a megoldás keresése során, de önmagukban természetesen nem garantálják azt.

Néhány, a matematikaproblémák megoldása során hasznosítható heurisztikus elv [3]:

- Analógiákban való gondolkodás

- Visszavezetés ismert problémára

- Invarianciaelv

- Esetmegkülönböztetés

- Optimalitás elve

- Sajátos-, illetve határesetek vizsgálata

- Szimmetriaelv

- Transzformációelv 
Schoenfeld [30] a kutatásai alapján kiegészítette, konkrétabbá, jobban használhatóbbá tette Pólya modelljét, ugyanakkor kiemelte a kognitív folyamatokról való aktív és tudatos gondolkodás, azaz a metakognitív elemek fontosságát is. Emellett rámutatott a kezdő, illetve a rutinos problémamegoldók módszerei közötti eltérésre: a kezdő problémamegoldókhoz képest a gyakorlottabbak több időt töltenek a megértés fázisával, a probléma elemzésével, többféle, új reprezentáció alkotásával.

A problémamegoldási folyamat szempontjából Schoenfeld a következő négy területet tartja fontosnak [17]:

1. Eredetek, források

A problémamegoldó azon ismeretei, amelyek a problémamegoldás során rendelkezésére állnak (müködőképes tudás):

- az adott területre vonatkozó intuíciók, informális ismeretek

- tények

- algoritmikus eljárások

- rutin, nem algoritmikus eljárások

- az adott témára vonatkozó megegyezések; elfogadott állítások, szabályok

2. Heurisztikák

Ismeretlen vagy nem standard problémák megoldását elösegítő stratégiák, technikák; a hatékony és eredményes problémamegoldás szabályai:

- ábra készítése, megfelelő jelölés bevezetése

- kapcsolódó problémák felhasználása

- a probléma átfogalmazása, fordított irányú okoskodás

- ellenőrző eljárások

3. Kontroll

Az egész problémamegoldási folyamatra kiható globális döntés, amely a megfelelő stratégia, illetve ismeret kiválasztására és alkalmazására vonatkozik:

- tervezés

- a terv ellenőrzése, értékelése, hatékonyságának mérlegelése

- döntés

- tudatos metakognitív tevékenységek

4. Meggyőződések

A problémamegoldó saját matematikai világa. Az egyén viselkedésének, magatartásának, tevékenységének (nem szükségszerüen tudatos) meghatározó tényezői:

- az egyén saját magáról alkotott véleménye

- az egyénnek a környezetről alkotott véleménye

- az egyénnek a tantárgyról, a tananyagról, a témáról alkotott véleménye

- az egyénnek a matematikáról alkotott véleménye 


\section{Metakognitív elemek}

A problémamegoldási folyamatot lépésekre bontva, figyelembe véve annak úgy a kognitív, mint a metakognitív aspektusát, adja meg Lester [19] a problémamegoldás egy modelljét [24]:

1. Orientáció: stratégiai viselkedés a probléma megértésére és értékelésére

Elemei: felfogási stratégiák, az információk elemzése, kezdeti és közbelső reprezentációk, a nehézség és sikeresség esélyeinek értékelése

Metakognitív mozzanatok: keresem a kulcsszavakat; keresek ehhez hasonló problémát

2. Szervezés: a viselkedés tervezése és választás a tevékenységek között

Elemei: célok azonosítása, globális és lokális tervezés

Metakognitív mozzanatok: azt gondolom, hogy ezt kell keresni, ez segíteni fog; ez nem müködik, mást kell keresnem

3. Végrehajtás: a viselkedés szabályozása a terv érdekében

Elemei: a terv kis lépéseinek végrehajtása, felügyelete, odafigyelés a pontosságra, sebességre, eleganciára

Metakognitív mozzanatok: ezt meg tudom csinálni; jobb lenne lassabban haladnom; ez túl bonyolult, óvatosan kell végrehajtanom a lépéseket; ez a módszer nem müködik, mást kell keresnem

4. Igazolás: a döntések és a végrehajtás eredményének értékelése

Elemei: az orientáció, szervezés és végrehajtás lépésének folyamatos vizsgálata, ellenörzése

Metakognitív mozzanatok: nem voltam elég óvatos, jobban kellene ellenőriznem a lépéseket; nem vagyok biztos benne, hogy értem a feladatot, újra kell olvasnom; ez az eredmény hibásnak tünik, ellenőriznem kell; azt gondoltam, hogy ez a módszer müködni fog, de úgy látom, mégsem

\section{Gondolkodási fázisok és müveletek}

Kissé más szemszögből közelít a problémamegoldási folyamat vizsgálatához Lénárd [18]. Az általa végzett kísérletek során a problémamegoldás lépésekre való bontása helyett, részletesen tanulmányozta a problémamegoldási folyamat szerkezetét, elemezte annak makro- és mikrostruktúráját.

A makrostruktúrát bizonyos gondolkodási fázisok alkotják, míg a mikrostruktúra gondolkodási műveletekből áll. Amíg a gondolkodási fázisok az egész gondolkodási folyamat alapján állapíthatók meg, addig a gondolkodási müveletek felismeréséhez elég egy-két gondolkodási lépést vizsgálni.

Lénárd [18] kilenc gondolkodási fázist sorol fel: ténymegállapítás, a probléma módosítása, megoldási javaslat, kritika, mellékes mozzanatok, csodálkozás-tetszés, bosszankodás, kételkedés, a munka feladása. Ezek mind jelen vannak a problémamegoldási folyamatban, sorrendjük természetesen függ a megoldótól és a megoldandó problémától, és egyes fázisok többször is előfordulhatnak. Ugyanakkor az említett érzelmek, mint a kételkedés vagy a bosszankodás, nem tevékenységek, hanem az egyes tevékenységek ve- 
lejárói. Kiváltják egy tevékenység beindulását, végigkísérik azt, vagy csupán a tevékenység befejezésekor jelennek meg.

A problémamegoldási folyamat mikrostruktúráját a gondolkodási müveletek alkotják. Lénárd [18] tizenegy gondolkodási müveletet sorol fel, melyek egymásba fonódva, rétegződve jelennek meg a problémamegoldási folyamatban: analízis, szintézis, absztrahálás, összehasonlítás, absztrahált adatok összehasonlítása, összefüggések felsorolása, kiegészítés, általánosítás, konkretizálás, rendezés, analógia.

\section{Ciklikus modell}

Wilson 2.1. ábrán látható diagramja [36] mutatja talán a legszemléletesebben a problémamegoldási folyamat ciklikus szerkezetét, amelynek központi eleme az irányító, szabályozó kontrolltevékenység.

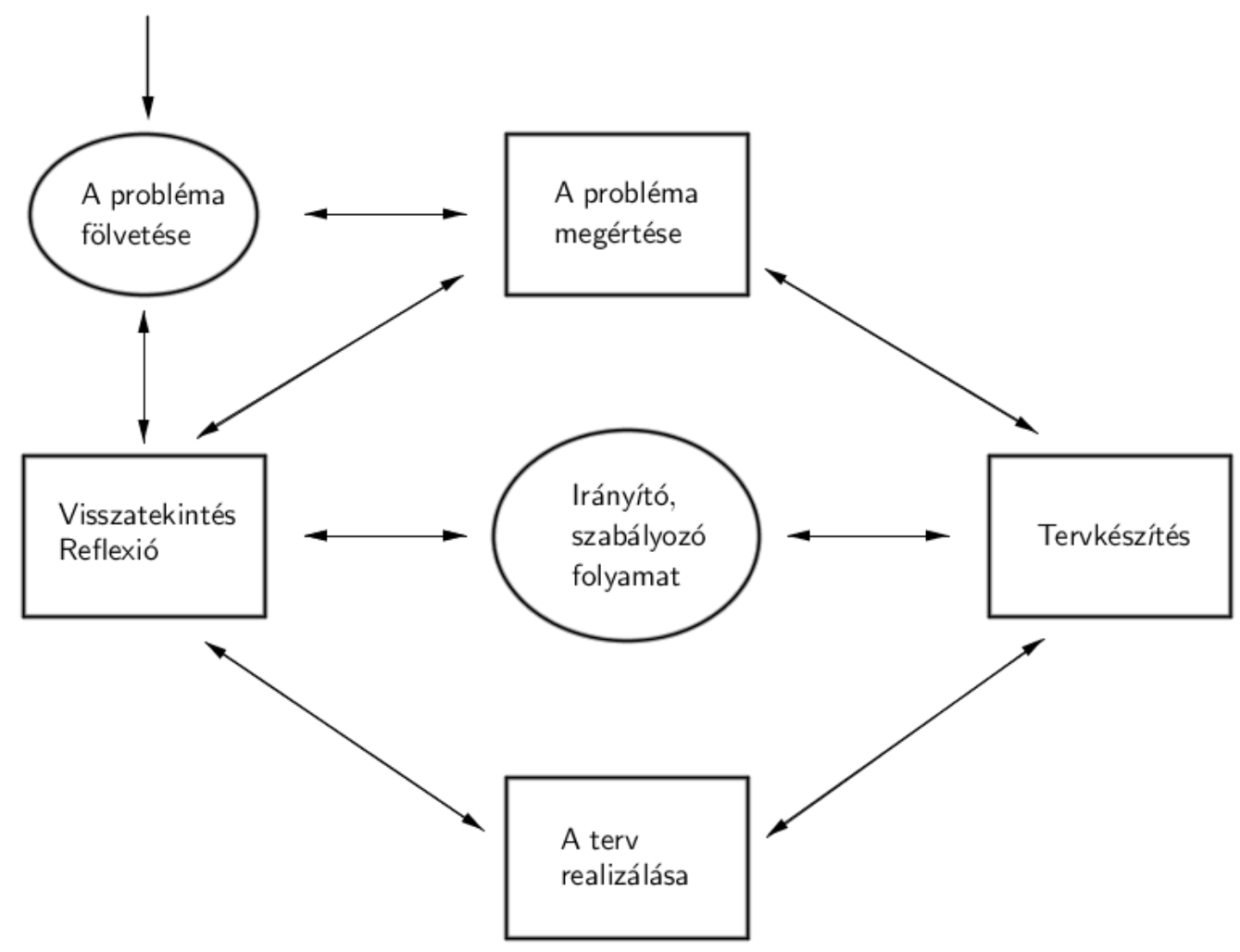

2.1. ábra. A problémamegoldás ciklikus folyamata

\subsection{A matematikai gondolkodás természete}

A problémamegoldó képesség fejlesztési lehetőségeinek számbavétele előtt, még szükséges az eddig vázolt problémamegoldási folyamatot végigkísérő gondolkodás természetének megértése is.

Devlin [8] szerint matematikai gondolkodásra minden ember genetikailag ugyanúgy képes, mint a beszéd elsajátítására, viszont nem ugyanolyan absztrakciós szinten. Nyilvánvaló, hogy mindenki képes olyan dolgokról gondolkodni, amelyek éppen nincsenek 
jelen a környezetében, vagy el tud képzelni egy tárgyat leírás alapján. Sőt, nem létező, kitalált dolgokról is tudunk gondolkodni. Viszont nem ugyanolyan szintü absztrakt gondolkodásról van szó, ha a szomszéd szobában levő, éppen nem látható asztalról gondolkodunk, vagy amikor matematikai fogalmakkal operálunk. Az elvont gondolkodásnak Devlin négy szintjét különbözteti meg [8]:

1. szintü absztrakció: az emberi környezetben jelen levő objektumokról való gondolkodás, ezek képzeletbeli elmozdítása

2. szintü absztrakció: ismert, de az adott pillanatban a közvetlen környezetünkben nem érzékelhető objektumokról való gondolkodás

3. szintü absztrakció: olyan képzeletbeli objektumokról való gondolkodás, amelyekről csak olvastunk, hallottunk, de sosem láttunk (pl. pegazus)

4. szintü absztrakció: matematikai objektumokkal végzett müveletek, matematikai gondolkodás

Azoknak, akiknek valóban nehézséget okoz a matematika, általában problémás az absztrakció legmagasabb szintjén gondolkodni. Ezért nekik általában sokkal könnyebb megoldani egy mindennapi élethelyzeten alapuló problémát, mint egy olyat, aminek a megoldása nagyobb mértékü elvonatkoztatást igényel. Viszont az egyre absztraktabb gondolkodás elsajátítása megfelelő módszerekkel általában fejleszthető [8].

\section{Külső és belső reprezentációk}

A matematikai fogalmakkal és elvekkel való operáláshoz elengedhetetlen azok valamilyen módon való reprezentálása. A szakirodalom [15] külső (tárgyi, vizuális és szimbolikus), illetve belső (mentális) reprezentációkat különböztet meg, melyek között szoros kapcsolat van. Ezenfelül a belső reprezentációk között is kapcsolat áll fenn, amely az ismeretek egy hálózatát adja. Ezen kapcsolatok mennyisége és minősége, a struktúra stabilitása teszi lehetővé a matematikai fogalmakkal és eljárásokkal való eredményes munkát [13], [21]. A megfelelő belső reprezentációk kialakítása érdekében, a szimbolikus reprezentációk kialakítása előtt, nagy hangsúlyt kell fektetni a tárgyi és képi külső reprezentációkra [2]. Ugyanakkor a matematikai gondolkodás sokkal hatékonyabb, ha a problémamegoldó egynél több reprezentációt használ párhuzamosan, és azokat összekapcsolja [9], [12]. Két ötlet közötti kapcsolat ugyanis csak akkor jön létre, ha ezek belső reprezentációi aktivizált állapotban egyszerre vannak jelen a munkamemóriában [1]. Ez az egyidejüség növeli a rugalmasságot, és rámutat a kapcsolatok rendkívül fontosságára. A matematika ereje éppen a reprezentációk közötti kapcsolatokban és a különböző objektumok reprezentációktól független tulajdonságaiban rejlik.

\section{Vizuális reprezentációk}

A matematikai struktúrák leírásában, elemzésében és a problémamegoldási folyamatban hasznos eszköz a vizualizáció. Mivel a vizuális gondolkodás nem korlátozódik a geometriai szituációkra, az elemi matematika sok problémája vizsgálható úgy analitikus, mind vizuális úton. 
Több kutató is arról számol be, hogy a képi szemléltetés segíti a gyengébb képességü diákokat a sikeres problémamegoldásban, hiszen míg geometriai környezetben alkalmaznak vagy kitalálnak bizonyos eljárásokat, addig algebrai környezetben ritkábban [9]. Másrészt viszont a problémahelyzet képi, vizuális szemléltetése, éppen konkrétsága miatt, gyakran korlátozott értékü. Presmeg [28] rámutat, hogy főleg kisgyerekek képesek létrehozni valamilyen vizuális képzetet, ám ez gyakran jóval kevesebb elemet tartalmaz, mint egy teljes reprezentáció, így az nem alkalmazható a problémamegoldás során. Mindemellett mivel a vizuális gondolkodásmód (akár globális vagy lokális, dinamikus vagy statikus) nem tisztán analitikus, még helyes vizuális reprezentáció esetén is szükséges az illető probléma lépésről lépésre haladó analitikus bizonyítása [9]. Éppen ezért rá kell nevelni a tanulókat a vizualitáson alapuló teljes elemző gondolkodásra, azaz a helyes vizuális gondolkodásmódra.

\section{Kritikai és kreatív gondolkodás}

Az elmúlt időszakban több nemzetközi kutatás foglalkozott az emberi agy bal, illetve jobb féltekéjének vizsgálatával. Hámori [16] megállapítja, hogy az emberek többségénél az egyes agyféltekékre dominánsan jellemzőek az alábbi tulajdonságok:

\begin{tabular}{l|l}
\multicolumn{1}{c|}{ Bal félteke } & \multicolumn{1}{c}{ Jobb félteke } \\
\hline - beszéd-, nyelvorientált & - néma, látó, térmanipuláló \\
- szekvenciális, digitális & - egyidejü, analóg \\
- logikus, analitikus & - szintetikus, holisztikus \\
- algebrikus & - geometrikus \\
- intelligens & - ösztönös \\
- konvergens & - divergens \\
- következtető & - kreatív \\
- racionális & - irracionális \\
- absztrakt & - tárgycentrikus \\
- realisztikus, objektív & - impulzív, szubjektív \\
- humorérzék hiánya & - humorérzék megléte \\
- irányított & - szabad \\
- időérzék megléte & - időtlen
\end{tabular}

Míg a nyugati kultúrákban inkább a verbális nyelv, az ésszerü, racionális, logikus gondolkodás, az elemzés hangsúlyozása a jellemző, addig a hagyományos keleti gondolkodás intuitív, meditatív, mitikus, nyugati értelemben néha irracionális [2].

Paivio [23] információfeldolgozó kódelmélete szerint mindenki két különböző módon (vizuálisan, illetve verbálisan) rögzíti az információkat. Ennek alapján Wachsmuth [35] kétféle matematikai gondolkodásmódról beszél.

\begin{tabular}{l|l}
\multicolumn{1}{c|}{ L-modus } & \multicolumn{1}{c}{ R-modus } \\
\hline - részletekre való figyelés & - részletek összerakása, átlátása \\
- rendszerezett gondolkodás & - (szabad) asszociációk \\
- lineáris gondolkodás & - időtől független, téri gondolkodás \\
- szavak, szimbólumok általi megértés & - szemléletesség általi megértés \\
- szeriális információfeldolgozás & - párhuzamos információfeldolgozás \\
- konvergens (tudatos) gondolkodás & - divergens (intuitív) gondolkodás
\end{tabular}


$\mathrm{Az}$ eredményes problémamegoldáshoz a fenti két gondolkodásmód ötvözése, kölcsönhatása szükséges, hiszen intuitív okoskodás nélkül, kizárólag logikus gondolkodással majdhogynem lehetetlen olyan célt elérni, amelyről semmit sem tudunk, ugyanakkor a divergens gondolkodásból származó ötletek megfelelő analizálásában a racionális bal agyfélteke a meghatározó. Mindezek alapján kijelenthető [20], hogy a problémamegoldás, mint gondolkodás, olyan komplex kognitív folyamat, amelyben egyenrangúan fontos és meghatározó szerepet játszik a meglévő tudás átszervezését irányító kritikai, és az új tudás megszerzését irányító kreatív gondolkodás. Ezt szemlélteti a 2.2. ábrán a problémamegoldás komplex kognitív modellje [33]. A kritikus gondolkodás három komponense az analizálás (elemzés), kiértékelés (feltárás) és az összefüggések keresése. A kreatív gondolkodás is három összetevőre bontható: a szintézis (összegzés), kidolgozás (felfedezés) és az összefüggések felismerése. Az intuitív, megérzésen alapuló okoskodás nélkülözhetetlen a keresési, tervkészítési fázisban, amikor valamilyen heurisztikus stratégia alkalmazására van szükség a tantárgyi tudáshiány (pl. algoritmikus ismeret) áthidalása érdekében. Ezzel szemben a racionális, kritikus gondolkodás a már meglévő tudás (pl. felismert algoritmus) alkalmazását, kisebb módosítását igénylö problémaszituációkban dominánsabb. Természetesen a gondolkodás e két aspektusa mellett az eredményes problémamegoldás meghatározó tényezői a meglévő tantárgyi tudás, a probléma iránti elkötelezettség (kellő motiváció) és a problémamegoldó metakognitív tudása. (2.2. ábra)

\begin{tabular}{|c|c|c|c|c|c|c|}
\hline \multicolumn{7}{|c|}{ A problémamegoldó gondolkodás } \\
\hline \multirow{3}{*}{ 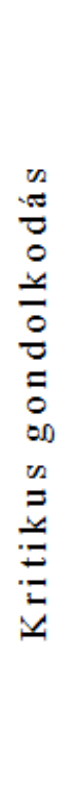 } & \multicolumn{3}{|c|}{\begin{tabular}{ll} 
& \multicolumn{1}{c}{ Analízis } \\
- & sémafelismerés \\
- & osztályba sorolás \\
- & feltételezések felismerése
\end{tabular}} & \multicolumn{2}{|c|}{\begin{tabular}{ll} 
& \multicolumn{1}{c}{ Szintézis } \\
- & analógiás gondolkodás \\
- & összefoglalás és rendszerezés \\
- & hipotézisalkotás
\end{tabular}} & \multirow{3}{*}{ 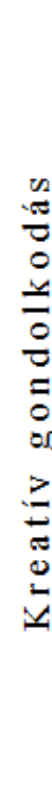 } \\
\hline & \multicolumn{3}{|c|}{$\begin{array}{l}\quad \text { Kiértékelés (feltárás) } \\
\text { - } \quad \text { releváns ismeretek számbavétele } \\
\text { - } \quad \text { kritériumok meghatározása, } \\
\text { azok prioritásának megadása } \\
\text { - } \quad \text { téves következtetések } \\
\text { felismerése } \\
\text { - } \quad \text { igazolás, ellenőrzés }\end{array}$} & \multicolumn{2}{|c|}{$\begin{array}{l}\quad \text { Kidolgozás (felfedezés) } \\
\text { - a meglévő ismeretek kibővítése, } \\
\text { kiterjesztése } \\
\text { - a meglévő tudás módosítása, } \\
\text { konkretizálása } \\
\text { - új fogalmi kategóriák } \\
\text { létrehozása }\end{array}$} & \\
\hline & \multicolumn{3}{|c|}{\begin{tabular}{ll} 
& \multicolumn{1}{c}{ Összefüggések keresése } \\
- & Összehasonlitás \\
- & logikus gondolkodás \\
- & induktív és deduktív \\
következtetések
\end{tabular}} & \multicolumn{2}{|c|}{$\begin{array}{ll} & \text { Összefüggések felismerése } \\
\text { - } & \text { eredeti gondolkodás } \\
\text { - } & \text { rugalmas gondolkodás } \\
\text { - } & \text { intuíció } \\
\text { - } & \text { heurisztikus gondolkodás }\end{array}$} & \\
\hline \multicolumn{3}{|c|}{ Meglévő tantárgyi tudás } & \multirow{2}{*}{\multicolumn{2}{|c|}{$\begin{array}{l}\text { A probléma iránti } \\
\text { elköteleződés }\end{array}$}} & \multirow{2}{*}{\multicolumn{2}{|c|}{ Metakognitív tudás }} \\
\hline & $\begin{array}{l}\text { etek } \\
\text { ratív) }\end{array}$ & $\begin{array}{c}\text { Képességek } \\
\text { (procedurális) }\end{array}$ & & & & \\
\hline
\end{tabular}

2.2. ábra. A problémamegoldás komplex kognitív modellje 


\subsection{A problémamegoldó képesség fejlesztése}

A matematikai problémamegoldó képesség fejlesztésével foglalkozó kutatások általában a tanári munkára vonatkozó javaslatokat (mit kell tudnia és tennie a fejlesztő tanárnak), illetve a diákok kognitív és metakognitív tevékenységére vonatkozó ajánlásokat fogalmaznak meg, ugyanakkor kitérnek az affektív tanítási célok eléréséhez szükséges feltételekre is.

\section{A kognitív képességek fejlesztése}

Dreyfus [9] szerint a flexibilis és sokoldalú problémamegoldó gondolkodás kialakítása érdekében kiemelten fontosak:

- az analógiákban való gondolkodás

- az egyes objektumok struktúráját legjobban szemléltető reprezentációk használata

- a vizuális gondolkodás

- a gondolatmenetek megfordítása

Claus [5] - Wittmannra [37] hivatkozva - a problémamegoldási képesség fejlesztése érdekében az alábbi feltételeket sorolja fel:

- ismeretszerzés felfedeztető tanítás és tanulás révén

- a tanulók divergens gondolkodásra való ösztönzése (ugyanannak a problémának több irányból történő megközelítése, többféle megfogalmazása; a matematika különböző területeinek összekapcsolása; a módszerek ötvözése)

- automatizált gondolatmenetek háttérbe szorítása

- nyitott problémák vizsgálata (többféle kérdésfeltevés; apró kutatási lehetőségek)

- a tanulók önálló problémafelvetésre való ösztönzése

- olyan nyelvi környezet kialakítása, amelyben a tanulók kifejezhetik gondolataikat

- intuitív indoklások, sejtések ösztönzése; a kicsi, de önálló lépések fontosságának tudatosítása egy bemutatott gondolatmenettel szemben

- heurisztikus stratégiák tanítása

- konstruktív magatartás kialakítása a hibákkal szemben

- diszkussziók, reflexiók, argumentációk ösztönzése 


\section{A metakogníció és kontroll fejlesztése}

Az eredményesebb problémamegoldás érdekében nem elég csupán a különböző kognitív képességek fejlesztése, szükséges a problémamegoldó gondolkodását végigkísérö metakognitív és kontrolltevékenység tudatosítása is [11], melyek központi eleme a problémamegoldó önmagával folytatott párbeszéde. Ez általában saját magának folyamatosan feltett kérdések sorozatából áll, amelyeket a tanítási, fejlesztési fázisban általában megkapnak a diákok, és segítségükre van a problémamegoldási folyamat során [25], [30], [17], [24].

Emellett elengedhetetlenül fontos a diákok önellenőrzésre nevelése [11]. Lényeges, hogy a tanuló ki tudja értékelni saját tevékenységét, tudja eldönteni az aktuális gondolat vagy lépéssorozat helyességét, esetleg annak elvetését. A kontrolltevékenység tudatosítása ugyancsak önkérdező módszerrel alakítható ki.

\section{Az affektív célok elérése}

A tanítás affektív céljainak elérése érdekében a kutatók a tanítási-tanulási módot vizsgálták [14]. Fontos, hogy a tanulók aktívan vegyenek részt a gondolkodási folyamatban, a probléma jelentsen kihívást számukra.

Skinner [32] kétféle - belső, ill. külső - motivációról beszél. Tartós, akár egész életen át tartó motiváltság csak maga a cselekmény végzése adta belső megerősítés (önbecsülés, büszkeség, elismerés) által érhetö el. Ezt a kognitív motivációelméletek is megerösítik, melyek szerint maga a tanulási folyamat kell ösztönzőleg hasson az egyénre.

Ennek elérése érdekében szükséges a megfelelő önbizalom kialakítása, amely Wittmann [37] szerint a hibákhoz való pozitív hozzáállás, a tanulók kérdések feltevésére való ösztönzése, és föleg nyitott problémák tanulmányozása során szerzett tapasztalatokon alapuló felfedeztetés, divergens gondolkodásra való nevelés által valósítható meg.

\section{Módszertani javaslatok}

Schoenfeld [29] kitért a tanári munkának a problémamegoldási folyamatban fellelhető három aspektusára (demonstratív, moderátor és edző szerep), valamint módszertani javaslatokat fogalmaz meg a foglalkozások szervezésével kapcsolatban [17].

A foglalkozást vezető tanár szerepei:

- Demonstratív szerep. A tanárnak demonstrálnia kell az egyes stratégiák alkalmazásának lehetőségeit, hatékonyságát, buktatóit, a teljes problémamegoldási folyamatot, ráirányítva a figyelmet a kritikusabb lépésekre.

- Moderátor szerep. A tanárnak a diákok javaslataira, kérdéseire reagálva irányítgatnia kell azokat. Nagyon hasznos lehet néhány zsákutcába vezető gondolatot együtt végigkövetni.

- Edző szerep: Többféleképpen megközelíthető és megoldható problémák esetén a tanárnak ki kell emelnie a legegyszerúbb, legcélszerübb utat, módszert. 
A foglalkozások szervezésével kapcsolatos javaslatok:

- A kizárólagosan tanár által bemutatott feladatmegoldások a foglalkozás idejének legfeljebb 10\%-át foglalják le.

- Mindig legyen házi feladat, melyeket a foglalkozások keretében a diákok javaslatai, megoldásai alapján alaposan, elemző módon meg kell beszélni.

- Egy adott stratégia tárgyalásához mindig legyen bevezető, irányadó probléma. Ez lehetőleg szép, érdekes, izgalmas probléma legyen.

- Új problémák esetén javasolt a diákokat 3-4 fôs csoportba osztani, és bizonyos ideig hagyni a csoportokat a problémán dolgozni. A tanulók között így kialakuló külső párbeszéd ösztönzi és fejleszti az önálló problémamegoldás során nagyon hasznos belső dialógust.

- A problémák közös megbeszélése során előbb a csoportok eredményei, a diákok gondolatai jelenjenek meg, a tanár lehetőleg ebből építkezzen (moderátor szerep).

\subsection{Kutatási előzmények}

A problémamegoldási képesség vizsgálatával foglalkozó szakdidaktikai kutatások száma jelentős, ám többségük csupán annak valamilyen szempontok alapján történő mérésére tér ki, nem társul hozzájuk fejlesztő foglalkozássorozat [38]. Ugyanakkor a különböző nemzetközi mérések hatására, túlnyomó többségük elemi osztályos vagy nagyobb általános iskolás tanulók szöveges feladat megoldási [34], illetve azokhoz tartozó vizuális reprezentáció készítési [6] képességet tanulmányoz, esetleg életszerű matematikai problémahelyzetek [22] megoldási képességével foglalkozik. Kevesebb azonban a középiskolás diákok, esetleg egyetemi hallgatók körében végzett, kifejezetten belső matematikai problémamegoldásra fókuszáló mérésekről és fejlesztő foglalkozásokról beszámoló eredmény, és még ritkább a heurisztikus problémamegoldási stratégiák effektív tanítására vonatkozó - közép-kelet európai - kutatás.

Schoenfeld [29] kutatásaira alapozva Kosztolányi [17] tanárjelöltek problémamegoldási képességének fejleszthetőségét vizsgálta. Kutatásának két fö célja volt. Egyrészt heurisztikus problémamegoldási stratégiák, technikák, eszközök tanítása a matematika különböző területeihez tartozó problémákon keresztül, másrészt a matematikai felfedezés, kutatás módszertani súlypontjainak bemutatása nyitott kérdések, problémák segítségével. Az elvégzett mérések alapján Kosztolányi arra a következtetésre jutott, hogy a stratégiák, technikák bizonyos mértékig taníthatók, hiszen a résztvevő hallgatók stratégiai eszköztára összességében fejlödött. Ugyanakkor a kutatásból az is kiderül, hogy míg egyes stratégiák (sajátos esetek tanulmányozása, vizsgálódás kevesebb változóval) nagyobb mértékben, addig mások (vizuális reprezentáció alkotása, transzformációelv alkalmazása) kevésbé fejleszthetők. Kosztolányi szerint ez azzal magyarázható, hogy míg az első két esetben a problémák jellege sugallja az alkalmazandó stratégiát, addig az utóbbiakban nem, mivel pl. az algebrai problémák tipikus algoritmussal történő analitikus megoldásának reflexe erös a diákokban, ez elnyomja a vizuális problémareprezentáció, a grafikus megoldás gondolatát, stratégiai jellegü ötletét [17]. 
Tanító és matematikatanár szakos föiskolai hallgatók körében végzett kutatásai alapján hasonló következtetésre jutott Pintér [24] is. A különböző problémamegoldási stratégiák explicit tanítására és problémaalkotásra vonatkozó fejlesztő kurzust követő mérésen a hallgatók minden területen jobban teljesítettek, mint a kurzus elején, azonban a geometriai konstrukciók algebrai összefüggéssé fordítása terén kisebb fejlődés figyelhető meg, mint más stratégiák alkalmazása esetén.

Többek között ezek a megfigyelések sarkalltak arra, hogy olyan problémák megoldásának taníthatóságával foglalkozzak, amelyek sikeres megoldása az eredeti megfogalmazás kontextusától eltérő, más területeken való okoskodást, más reprezentációban való gondolkodást igényel. Célom egyrészt a vizuális problémareprezentációk készítésének, elemzésének és a problémamegoldási folyamatban való sikeres alkalmazási képességének fejlesztése, másrészt a diákok szintetizáló, a különböző tananyagrészek összekapcsolására vonatkozó képességének mérése és fejlesztése volt. Úgy gondolom, hogy az ilyen jellegü problémákkal való foglalkozás nagymértékben hozzájárul a diákok divergens gondolkodásmódjának kialakításához, valamint a matematikáról alkotott képük gazdagodásához, kiszélesedéséhez. 


\section{3. fejezet}

\section{A kutatás anyaga és módszere}

2011, majd 2013 tavaszán három hónapon keresztül 10-11. osztályos tanulók, valamint II. és III. éves matematika szakos egyetemi hallgatók problémamegoldási képességeit vizsgáltam. A kutatás elő- és utóméréses kísérleti módszerrel valósult meg, melyek között heti rendszerességgel fejlesztő foglalkozások zajlottak. A fejlesztés pontos céljának és anyagának meghatározása érdekében a diákok először egy előtesztelésen vettek részt.

\subsection{Az előmérés}

Az előtesztet 33 líceumi és 26 egyetemi diák írta meg, de csak annak - a matematika iránt jobban érdeklődő - 23 középiskolás tanulónak és 24 egyetemi hallgatónak az eredményeivel foglalkozom, akik az utómérésen is jelen voltak. Tehát összesen 47 diák teljesítményét tanulmányozom.

\subsubsection{Az elöteszt célja}

Célom annak fölmérése volt, hogy a kísérletben részt vevő diákok

- milyen általános problémamegoldási heurisztikákat ismernek,

- mennyire tudják a matematika különböző területeiről származó tudásukat a feladatmegoldás során mozgósítani, képesek-e a különböző jellegü ötleteiket ötvözni,

- bizonyos problémák esetén próbálkoznak-e a feladat kijelentésétől eltérő, más reprezentációkban való okoskodással,

- problémamegoldás közben milyen metakognitív gondolatok jelennek meg, illetve milyen érzelmek játszódnak le bennük, és mennyire tudják ezeket közölni.

A felmérésnek egy másik célja a középiskolás és egyetemista csoport eredményeinek az összehasonlítása, az esetleges különbségekre való rávilágítás. 


\subsubsection{Az előmérés módszere}

A felmérésen részt vevő 47 diáknak 90 perc alatt 3 nem szokványos, versenyfeladatnak tekinthető problémát kellett megoldania.

Mivel a teljes problémamegoldási folyamat minden vetületére kíváncsi voltam, a teszt elején a következő szempontokra hívtam fel a figyelmüket:

- A lapot függőlegesen kettéválasztva bal oldalra a feladatok megoldását, jobb oldalra a gondolataikat, érzéseiket írják le.

- Bármelyik probléma megoldásával kezdhetik, de mindegyik megoldását részletesen írják le.

- Minden feladathoz annyi megoldást adjanak, amennyit csak tudnak.

- Ha valamelyik feladattal nem boldogulnak, írják le a megfigyeléseiket, sejtéseiket.

- Még akkor is hagyjanak a lapon minden észrevételt, ötletet, ha utólag esetleg kiderül róla, hogy használhatatlan vagy hibás.

\subsubsection{A feladatok megoldása és értékelése}

\section{Feladatok}

1. Határozd meg az $\left\{\begin{array}{l}x+y+z=3 \\ x^{2}+y^{2}+z^{2}=3\end{array}\right.$ egyenletrendszer valós megoldásait!

2. Bizonyítsd be, hogy bármilyen $a, b, c>0$ esetén

$$
\sqrt{a^{2}-a b+b^{2}}+\sqrt{a^{2}-a c+c^{2}} \geq \sqrt{b^{2}+b c+c^{2}} .
$$

3. Egy lakatlan szigeten miután a kalózok felhúzták a zendülőket az $(A)$ akasztófára, a következő módon ásták el kincseiket: Kimérték a távolságot az akasztófától az $(F)$ forrásig, majd jobbra fordultak, és ugyanannyit léptek, mint $A$-tól $F$-ig, majd itt kijelölték a $K_{1}$ pontot. Hasonlóan, az akasztófától a $(B)$ barlangig lépkedtek, balra fordultak, majd ugyanannyit léptek, mint $A$-tól $B$-ig, és kijelölték a $K_{2}$ pontot. Végül a $\left[K_{1} K_{2}\right]$ felezőpontjánál elásták a kincset. Húsz év múlva a kapitány visszatért, hogy magával vigye a kincseket. Nagy meglepetésére az akasztófát sehol sem találta. Megtalálhatja-e a kincseket?

\section{Megoldások}

1. feladat. Határozd meg az $\left\{\begin{array}{l}x+y+z=3 \\ x^{2}+y^{2}+z^{2}=3\end{array}\right.$ egyenletrendszer valós megoldásait!

1. megoldás. Látható, hogy a feladatban két egyenlet és három ismeretlen szerepel, de más ötlet nem lévén, a legkézenfekvőbbnek mégis az tünik, hogy fejezzük ki az első egyenletből valamelyik ismeretlent a másik kettő függvényében, majd helyettesítsük be a második egyenletbe, és foglalkozzunk az így kapott kétismeretlenes egyenlettel. A létrejövő egyenlet másodfokú lesz, így az egyik ismeretlen szerint rendezve 
a tagokat, könnyedén vizsgálhatjuk a megoldásokat a diszkrimináns segítségével. A diszkrimináns természetesen csak a harmadik (eddig különösebb szerepet nem játszó) ismeretlentől fog függni.

Tehát $z=3-x-y$-t behelyettesítve a második egyenletbe, kapjuk, hogy

$$
\begin{gathered}
x^{2}+y^{2}+9-6 x-6 y+x^{2}+y^{2}+2 x y=3, \\
2 x^{2}+2 y^{2}+2 x y-6 x-6 y+6=0, \\
x^{2}+(y-3) x+y^{2}-3 y+3=0 .
\end{gathered}
$$

Ekkor $\Delta=(y-3)^{2}-4\left(y^{2}-3 y+3\right)=-3 y^{2}+6 y-3=-3 \cdot(y-1)^{2} \leq 0$, így valós megoldás csak $\Delta=0$ esetén van, ahonnan következik, hogy $y=1$. Innen viszont rögtön következik, hogy $x=1$ és $z=1$. Tehát $M=\{(1,1,1)\}$.

2. megoldás. Lényegileg az előző megoldást hatjuk végre, ha az egyik ismeretlent paraméternek tekintjük (pl. legyen $z=\lambda, \lambda \in \mathbb{R}$ ), majd megoldjuk a két egyenletből álló kétismeretlenes paraméteres szimmetrikus egyenletrendszert. Ekkor

$$
\left\{\begin{array} { l } 
{ x + y = 3 - \lambda } \\
{ x ^ { 2 } + y ^ { 2 } = 3 - \lambda ^ { 2 } }
\end{array} \Longleftrightarrow \left\{\begin{array} { l } 
{ s = 3 - \lambda } \\
{ s ^ { 2 } - 2 p = 3 - \lambda ^ { 2 } }
\end{array} \Longleftrightarrow \left\{\begin{array}{l}
s=3-\lambda \\
p=\lambda^{2}-3 \lambda+3
\end{array},\right.\right.\right.
$$

ahol $s:=x+y$ és $p:=x y$, és a keresett $x, y$ értékek a $t^{2}-s t+p=0$ egyenlet megoldásai. Látható, hogy ismét a

$$
t^{2}-(3-\lambda) t+\lambda^{2}-3 \lambda+3=0
$$

egyenlethez jutottunk, melynek csak $\Delta=0$ esetén van megoldása. Ekkor $\lambda=1$, ahonnan $t_{1,2}=1$, azaz $x=y=z=1$. Tehát $M=\{(1,1,1)\}$.

3. megoldás. Ez a megoldás lényegesen különböző az előző két megoldási módszertől. Gondolkodhatunk úgy is, hogy mivel csak két egyenlet van és három ismeretlen, ezért elönyös lenne például olyan $x, y, z$-től függö teljes négyzeteket kialakítani, melyek összege éppen 0. Ekkor mivel a négyzetek mind nemnegatívak, ezért a megjelenő kifejezések értéke mind nulla kell legyen, ahonnan már könnyen meghatározhatók a keresett értékek.

Ennek érdekében vonjuk ki a második egyenletből az első egyenlet kétszeresét, majd rendezzük balra az egyenletet, és alakítsuk ki teljes négyzeteket. Ekkor

$$
x^{2}+y^{2}+z^{2}-2 x-2 y-2 z=3-6 \Longleftrightarrow(x-1)^{2}+(y-1)^{2}+(z-1)^{2}=0,
$$

ahonnan $x=y=z=1$. Visszahelyettesítéssel ellenőrizhető, hogy $M=\{(1,1,1)\}$.

Megjegyzés. Fontos megjegyezni, hogy mivel a két egyenlet kivonásakor nem ekvivalens lépést hajtottunk végre, a kapott megoldásjelölteket mindenképpen ellenőrizni kell. Ennek elmulasztása hamis megoldáshoz vezethet. Például az $\left\{\begin{array}{l}x+y+z=2 \\ x^{2}+y^{2}+z^{2}=1\end{array}\right.$ egyenletrendszer második egyenletéből kivonva az első egyenlet kétszeresét, ugyancsak az $(x-1)^{2}+(y-1)^{2}+(z-1)^{2}=0$ egyenlethez jutunk, ahonnan $x=y=z=1$, de ezek nem megoldásai az eredeti egyenletrendszernek. 
4. megoldás. Az egyenletek bal oldalán három valós érték összege, illetve négyzetösszege jelenik meg. Erről eszünkbe juthatnak a számtani és négyzetes közepek, valamint az azok közötti egyenlőtlenség. Mindez tisztábban látszik, ha az egyenletrendszert a következő alakba írjuk:

$$
\frac{x+y+z}{3}=\frac{x^{2}+y^{2}+z^{2}}{3}=1 .
$$

Egyenlőtlenséget olyankor érdemes egyenlet megoldásába behozni, ha az egyenlet előáll az illető egyenlőtlenség sajátos eseteként (határeseteként). Mivel

$$
1=\frac{x+y+z}{3} \leq \sqrt{\frac{x^{2}+y^{2}+z^{2}}{3}}=1,
$$

ezért a közepekben megjelenő három érték megegyezik, ahonnan $x=y=z=1$, tehát $M=\{(1,1,1)\}$.

5. megoldás. Legyenek $x, y$ és $z$ a $t^{3}+b t^{2}+c t+d=0, b, c, d \in \mathbb{R}$ harmadfokú polinomiális egyenlet megoldásai.

Mivel $x^{2}+y^{2}+z^{2}=(x+y+z)^{2}-2(x y+y z+z x)$, ezért $x y+y z+z x=3$. Ekkor a Viète-összefüggések alapján $x+y+z=-b=3$, ahonnan $b=-3$, és $x y+y z+z x=c$, tehát $c=3$, így a $t^{3}-3 t^{2}+3 t+d=0$ egyenlethez jutunk, és keressük annak megoldásait.

Mivel az

$$
f: \mathbb{R} \rightarrow \mathbb{R}, \quad f(t)=t^{3}-3 t^{2}+3 t+d
$$

harmadfokú polinomfüggvény

$$
f^{\prime}(t)=3 t^{2}-6 t+3=3(t-1)^{2}, \quad t \in \mathbb{R}
$$

deriváltfüggvényének csak egy zérushelye van, ezért az $f$ függvény zérushelyei mind egyformák, hiszen, ha nem lennének mind egyformák, akkor a deriváltfüggvénynek két zérushelye kellene legyen.

Így a $t_{0}=1$ háromszoros gyöke az $f(t)=0$ egyenletnek, ahonnan kapjuk, hogy $t^{3}-3 t^{2}+3 t-1=0$, tehát $x=y=z=1$.

6. megoldás. Alkalmazzuk a Cauchy - Bunyakovszkij - Schwarz - egyenlőtlenséget a

$$
\overrightarrow{v_{1}}=(1,1,1) \quad \text { és } \quad \overrightarrow{v_{2}}=(x, y, z)
$$

vektorokra. Ekkor

$$
\left|\overrightarrow{v_{1}} \cdot \overrightarrow{v_{2}}\right| \leq\left\|\overrightarrow{v_{1}}\right\| \cdot\left\|\overrightarrow{v_{2}}\right\|
$$

ahonnan

$$
3=|1 \cdot x+1 \cdot y+1 \cdot z| \leq \sqrt{1^{2}+1^{2}+1^{2}} \cdot \sqrt{x^{2}+y^{2}+z^{2}}=\sqrt{3} \cdot \sqrt{3}=3,
$$

és egyenlőség pontosan akkor áll fenn, ha $\frac{x}{1}=\frac{y}{1}=\frac{z}{1}$, ahonnan $x=y=z=1$. 
7. megoldás. Nézzük a feladatot geometriai szemszögből! A második egyenlet tekinthető egy origó középpontú $\sqrt{3}$ sugarú gömb egyenletének. Az első egyenlet egy sík egyenlete. A sík a gömböt vagy nem metszi (nincs megoldás), vagy érinti (1 megoldás), vagy egy körben metszi (végtelen sok megoldás). Mivel a gömb origó középpontú, ezért a síknak az origótól való távolsága elárulja, hogy a három eset közül melyik áll fenn. Jelöljük a síkot $\alpha$-val, a gömb sugarát pedig $R$-rel $(R=\sqrt{3})$. Mivel

$$
d(O, \alpha)=\frac{|1 \cdot 0+1 \cdot 0+1 \cdot 0-3|}{\sqrt{1^{2}+1^{2}+1^{2}}}=\frac{3}{\sqrt{3}}=\sqrt{3}=R,
$$

ezért a sík érinti a gömböt, így a rendszernek csak egy megoldása van: az érintési pont koordinátái. Ez kiszámítható (lásd az első két megoldást), vagy kitalálható, és mivel csak egy metszéspont van, azért ez az egyetlen megoldás. Tehát $M=\{(1,1,1)\}$.

Megjegyzés. Az utolsó megoldás előnye, hogy rávilágít az ilyen típusú egyenletrendszerek megoldásainak struktúrájára, megmutatja, hogy milyen esetekben hány megoldása van a rendszernek. Kevésbé látványosan ugyan, de a korábbi megoldási módszerekből is következtetni lehet a megoldások számára. Az első két megoldási mód esetén, ha a diszkrimináns értéke negatív, akkor nincs megoldás, ha viszont pozitív, akkor végtelen sok van, melyek paraméteresen jelentkeznek. A nevezetes közepek közötti egyenlőtlenség alkalmazásakor, ha szigorú az egyenlőtlenség, akkor végtelen sok megoldás van, míg ha hamis állításhoz jutunk, akkor nincs megoldása a rendszernek.

Célom az első feladattal annak vizsgálata volt, hogy a jól ismert lineáris, illetve arra visszavezethető egyenletrendszerek megoldási módszerein kívül, a diákok rendelkezésére áll-e más megoldási módszer, technika, amely nem standard egyenletrendszerek megoldásakor használható lehet. Konkrétan: eszükbe jut-e teljes négyzetek kialakítása (7-8. osztályban a rövidített számítási képletek tanulásakor többismeretlenes egyenletek megoldása során már találkozhattak hasonló ötlettel), esetleg a nevezetes középértékek közötti, vagy más egyenlőtlenség (Cauchy) felhasználása. Igaz, az utóbbi években a négyzetes középérték már nem kötelező iskolai tananyag, így a középiskolások egy részének eszébe sem juthatott. Néhány éve ugyancsak nem tananyag az analitikus térmértan, így a geometriai jellegű megoldás is csak az egyetemisták stratégiai eszköztárában szerepelhetet.

Meglepetésemre a 23 középiskolai tanulóból csak 3 oldotta meg tökéletesen a feladatot, és érdekes, hogy mind különbözőképpen: egy diák az 1., egy a 3. és egy a 4. megoldási módszerrel. Még 10 tanuló közölte, hogy az $(1,1,1)$ megoldása a rendszernek, és próbálta, de nem tudta bizonyítani, hogy más megoldás nincs.

„Észrevettem, hogy $x=y=z=1$ jó. Megpróbálom igazolni, hogy más megoldás nincs ... Valami rövidített számítási képletet kellene kialakítani ... Vagy esetleg reductio ad absurdummal bizonyítani, hogy ez az egyetlen megoldás?"

A többi 10 diák néhány lépésnyi alakítgatás után vagy feladta, vagy hibás indoklással arra a következtetésre jutott, hogy a megoldás az $(1,1,1)$, és esetleg más megoldás létezése fel sem merült bennük.

„,Hogy lehet 2 egyenletből 3 ismeretlent meghatározni? ... Ki kellene emelni valamit... Kapcsolatot kellene teremtsek a két egyenlet között ... Ezt a feladatot nem lehet megoldani, mert eggyel kevesebb egyenlet van, mint ismeretlen."

Az egyetemisták közül 8 hallgató oldotta meg jól a feladatot, egyikőjük 2 módszerrel is. A 8 hallgatóból 1 gondolkodott geometriai módon, sikerrel. 
„,Rájöttem, hogy $x=y=z=1$ megoldás, s gondolom ez az egyedüli. Az egyenleteket látva eszembe jutnak a számtani és négyzetes közepek és az azok közötti egyenlőtlenség. ... Teljes négyzetek kialakításával is megy, sőt még egyszerübb is."

„,Megpróbálom kétismeretlenessé alakítani az egyenletet, ezért z-t paraméternek tekintem, és mindkét egyenletben jobbra viszem. Kifejezem az első egyenletből x-et, majd behelyettesítem a második egyenletbe, és azt megoldom, mint másodfokú egyenletet."

Rajtuk kívül 9 diák sejtette meg a megoldást, de nem sikerült bizonyítania az unicitását, közülük 2 elrontotta a számolást. Még 2 hallgató próbálkozott geometriai indoklással, sikertelenül. A többi 5 diák néhány lépésnyi algebrai átalakítás után feladta a gondolkodást.

„Azért, hogy csökkenjen az ismeretlenek száma, az egyiket kifejezhetjük, és behelyettesíthetjük a másik egyenletbe ... vagy négyzetre emelem az első egyenletet, és kivonom belöle a másodikat ... de így vegyes szorzatok is lesznek ... lehet, hogy könnyebb lenne ha a feladat geometria jelentését használnák, vagyis, hogy az egyik egy gömb egyenlete, a másik meg egy síké, a kettő keresztmetszete pedig egy kör ... de lehet pont is, ha csak érinti ... de nem jön ki semmi."

„,Viète-féle összefüggések kellenének? ..."

„,Jó volna, ha lenne még egy feltételünk. ... Egyenletrendszerek megoldását 11. osztályban tanultuk. ... Próbálkozom a mátrix, illetve determinánsos módszerrel, hogy ellenőrizzem, hogy az egyenletrendszer kompatíbilis-e, de erre nem tudom felírni."

,Ezt a feladatot még nem láttam. Az első gondolatom az, hogy két egyenlet van és három ismeretlen, tehát tuti valamilyen csellel kell megoldani, de semmi ötletem sincs."

Az eredményeket az alábbi táblázat foglalja össze.

\begin{tabular}{l|c|c} 
& Középiskolás tanuló & Egyetemi hallgató \\
\hline Teljes, helyes megoldás & $3 / 23 \approx 13 \%$ & $8 / 24 \approx 33,34 \%$ \\
\hline \hline Jó sejtés bizonyítás nélkül & $10 / 23 \approx 43,5 \%$ & $9 / 24 \approx 37,5 \%$ \\
\hline Geometriai gondolat & $0 / 23 \approx 0 \%$ & $3 / 24 \approx 12,5 \%$ \\
\hline \hline Hibás megoldás & $10 / 23 \approx 43,5 \%$ & $7 / 24 \approx 29,16 \%$
\end{tabular}

2. feladat. Bizonyítsd be, hogy bármilyen $a, b, c>0$ esetén

$$
\sqrt{a^{2}-a b+b^{2}}+\sqrt{a^{2}-a c+c^{2}} \geq \sqrt{b^{2}+b c+c^{2}} .
$$

1. megoldás. Első gondolatunk a gyökök kiküszöbölése lehet. Ez két négyzetre emeléssel érhető el, utána a tagok megfelelő csoportosításával megpróbáljuk igazolni az egyenlőtlenséget. A megfelelő feltételeket szem előtt tartva, négyzetre emelve az egyenlőtlenséget, kapjuk, hogy

$$
2 \sqrt{a^{2}-a b+b^{2}} \sqrt{a^{2}-a c+c^{2}} \geq a b+a c+b c-2 a^{2} .
$$

Ha a jobb oldal negatív, akkor végeztünk, különben újra négyzetre kell emelni, majd a tagok némi átrendezésével kapjuk, hogy

$$
a^{2} b^{2}+a^{2} c^{2}+b^{2} c^{2}+2 a^{2} b c-2 a b^{2} c-2 a b c^{2} \geq 0 \Longleftrightarrow(a b+a c-b c)^{2} \geq 0,
$$

ami nyilvánvalóan igaz. 
2. megoldás. Tekintsük az egyenlőtlenség bal oldalát, mint $a$-tól függő $b$-ben és $c$-ben paraméteres kifejezést. Legyen ekkor

$$
f: \mathbb{R}_{+} \rightarrow \mathbb{R}, \quad f(x)=\sqrt{x^{2}-b x+b^{2}}+\sqrt{x^{2}-c x+c^{2}}, \quad b, c>0 \text { paraméterek. }
$$

Matematikai analízisbeli eszközökkel igazolható, hogy a függvény minimumhelye $x_{0}=\frac{b c}{b+c}$, melyet visszahelyettesítve a függvény minimumát kapjuk, ami éppen $\sqrt{b^{2}+b c+c^{2}}$. Tehát $f(x) \geq \sqrt{b^{2}+b c+c^{2}}, \forall x>0$ esetén, ahonnan

$$
\sqrt{a^{2}-a b+b^{2}}+\sqrt{a^{2}-a c+c^{2}} \geq \sqrt{b^{2}+b c+c^{2}}, \forall a, b, c>0 \text { esetén. }
$$

3. megoldás. Ha jól megfigyeljük a gyökök alatti kifejezéseket, észrevehető, hogy mindhárom esetben két változó négyzete és azok szorzata szerepel. Eszünkbe juthat a koszinusztétel: $z^{2}=x^{2}+y^{2}-2 x y \cos \gamma$

Az első gyök alatti $a^{2}+b^{2}-a b$ alakot akkor kapunk, ha az illető szög koszinusza $\frac{1}{2}$, azaz ha a szög mértéke $60^{\circ}$. Így geometriailag könnyen ábrázolható mindhárom kifejezés, hiszen a jobb oldalon $120^{\circ}$-os szög van elrejtve.

Tehát mindhárom négyzetgyök egy-egy szakasz hosszát jelöli, és bizonyítani kell, hogy két szakasz hossza nem kisebb egy harmadik szakasz hosszánál. Ilyesmi a háromszög-egyenlőtlenségben fordul elő, tehát egy olyan ábrát kell készíteni, amelyen a bizonyítandó egyenlőtlenségben szereplő négyzetgyökök egy háromszög oldalhosszaiként jelennek meg.

Szerkesszük meg az $A O B$ és $A O C$ háromszögeket úgy, hogy $O A=a, O B=b$, $O C=c$ és $m(\widehat{A O B})=m(\widehat{A O C})=60^{\circ}$, valamint $B$ és $C$ az $O A$-hoz viszonyítva ellentétes félsíkban legyen (3.1. ábra).

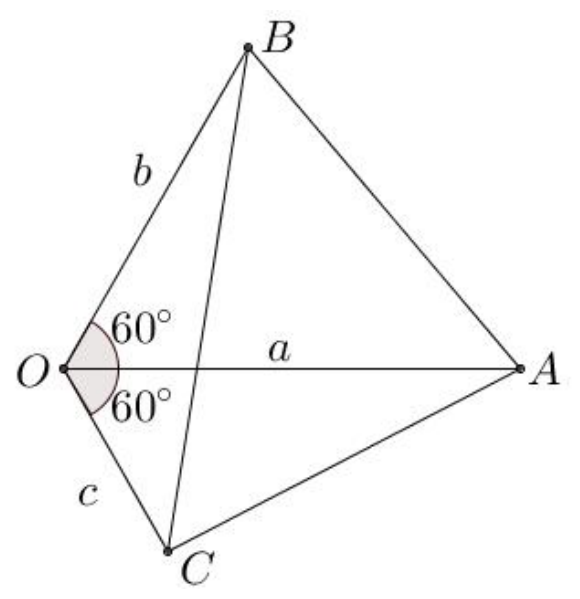

3.1. ábra. A feladat geometriai modellje

A koszinusztétel alapján

$$
A B=\sqrt{a^{2}-a b+b^{2}}, A C=\sqrt{a^{2}-a c+c^{2}} \text { és } B C=\sqrt{b^{2}+b c+c^{2}} .
$$

Az $A B C_{\triangle}$-ben a háromszög-egyenlőtlenség alapján $A B+A C \geq B C$, vagyis

$$
\sqrt{a^{2}-a b+b^{2}}+\sqrt{a^{2}-a c+c^{2}} \geq \sqrt{b^{2}+b c+c^{2}} .
$$


A második feladat esetén arra voltam kíváncsi, hogy a diákoknak eszükbe jut-e egy algebrai probléma esetén a geometriai úton való próbálkozás. Észreveszik-e, hogy a gyökkifejezések szakaszhosszként reprezentálhatók, így tulajdonképpen két szakasz összhosszáról kell kimutatniuk, hogy nem kisebb, mint egy harmadik szakasz hossza. És ha eddig eljutnak, sikerül-e olyan ábrát készíteni, amelyről már könnyen leolvasható a háromszögegyenlőtlenség.

A 23 középiskolai tanulóból 4 diáknak fordult meg a fejében, hogy az egyenlötlenség esetleg geometriailag is interpretálható, közülük hárman megtalálták a megfelelő modellt, és tökéletesen meg is oldották a feladatot. A többiek algebrai úton próbálkoztak, és általában egyszeri négyzetreemelés után abbahagyták a számításokat. Érdekes, hogy hasonló formájú (gyökkif. + gyökkif. = gyökkif.) irracionális egyenletekkel 10. osztályban foglalkoztak, így tudhatták, hogy egyszeri négyzetreemeléssel nem tüntethetők el a gyökök, mégis leálltak ezután. Ebből arra következtetek, hogy a megjelenő sok tag kezelése fölülmúlta a munkakapacitásukat.

„A koszinusztétel jobb oldalához hasonlítanak a gyök alatti kifejezések. ... Egy háromszögben két oldal hossza nagyobb vagy egyenlő a harmadikéval."

„Eszembe jutottak a rövidített számítási képletek, csak a középső tag kétszer kellene legyen. Vagy az általános Pitagorasz-tétel kell?"

„,Félek négyzetre emelni, de megpróbálom ... nem használ, ráadásul kevés az idő, és még csak evvel a feladattal foglalkoztam, túlbonyolítottam ... nem sikerül. Megállt a tudomány."

A 24 egyetemi hallgató közül 6 gondolt geometria modell készítésére, de tökéletesen csak 2 vitelezte ki a megoldást. A többiek algebrai úton gondolkodtak, de csak 2 hallgatónak sikerült kétszeri négyzetreemeléssel helyesen megoldania a feladatot.

„A gyök alatti kifejezések majdnem teljes négyzetek. Esetleg ha hozzáadnám a hiányzó tagot és le is vonnám, akkor jutnék valamire. ... Ha az egyenlőtlenséget négyzetre emelném, az sem lenne célravezető szerintem. ... Egy érdekes cselt kell szerintem alkalmazni, csak nem jövök rá, hogy mit. ... Különböző egyenlőtlenségek jutnak eszembe: Minkowski, Cauchy, Young, számtani-mértani közepek közötti ... A geometriát hívjuk segítségül. A gyökökröl eszembe jutott a koszinusztétel."

,Négyzetre emelve megszabadulok a gyökök egy részétől, majd rendezem, és megint négyzetre emelem. ... Elég bonyolult, de keresem, hogy minek a négyzete. ..."

\begin{tabular}{l|c|c} 
& Középiskolás tanuló & Egyetemi hallgató \\
\hline Teljes, helyes megoldás & $3 / 23 \approx 13 \%$ & $4 / 24 \approx 16,67 \%$ \\
\hline \hline Ebből geometriai úton & $3 / 23 \approx 13 \%$ & $2 / 24 \approx 8,33 \%$ \\
\hline Geometriai gondolat & $4 / 23 \approx 17,4 \%$ & $6 / 24 \approx 25 \%$ \\
\hline \hline Nem oldotta meg & $20 / 23 \approx 87 \%$ & $20 / 24 \approx 83,33 \%$
\end{tabular}

3. feladat. Egy lakatlan szigeten miután a kalózok felhúzták a zendülőket az $(A)$ akasztófára, a következő módon ásták el kincseiket: Kimérték a távolságot az akasztófától az $(F)$ forrásig, majd jobbra fordultak, és ugyanannyit léptek, mint $A$-tól $F$-ig, majd itt kijelölték a $K_{1}$ pontot. Hasonlóan, az akasztófától a $(B)$ barlangig lépkedtek, balra fordultak, majd ugyanannyit léptek, mint $A$-tól $B$-ig, és kijelölték a $K_{2}$ pontot. Végül a $\left[K_{1} K_{2}\right]$ felezőpontjánál elásták a kincset. Húsz év múlva a kapitány visszatért, hogy magával vigye a kincseket. Nagy meglepetésére az akasztófát sehol sem találta. Megtalálhatja-e a kincseket? 
1. megoldás. Mikor van egyáltalán esélye a kapitánynak megtalálni a kincset? Némi gondolkodás után rájöhetünk, hogy ez csak akkor lehetséges, vagyis csak akkor található meg a $K$ pont helye, ha az $A$ akasztófa mozgatásával a kincs helye keveset változik, vagy legalábbis kis területen belül mozog. A feladat matematikai szóhasználattal a $K$ pont mértani helyének megtalálását kéri, amikor az $A$ pont mozog.

Ugyanakkor sejthetjük, hogy mivel az akasztófa már nincs meg, a kincs csak akkor található meg, ha annak helye egyáltalán nem függ az akasztófa helyétől, csak a forrásétól és a barlangétól. Némi kísérletezés után, még számítógépes geometriai program használata nélkül is rájöhetünk, hogy ez valóban így is van.

A sejtés bizonyítása már valamivel nehezebb probléma. Mivel a feladat szövegében 90-os távolságtartó forgatások szerepelnek, kézenfekvő a geometriai objektumok algebrai úton, komplex számok segítségével való kezelése.

Ki kell tehát számítani a $K$ pont affixumát a többi pont affixuma segítségével. Közben arra számítunk, hogy az eredményben nem fog szerepelni az $A$ pont affixuma, csak a $B$, illetve az $F$ ponté.

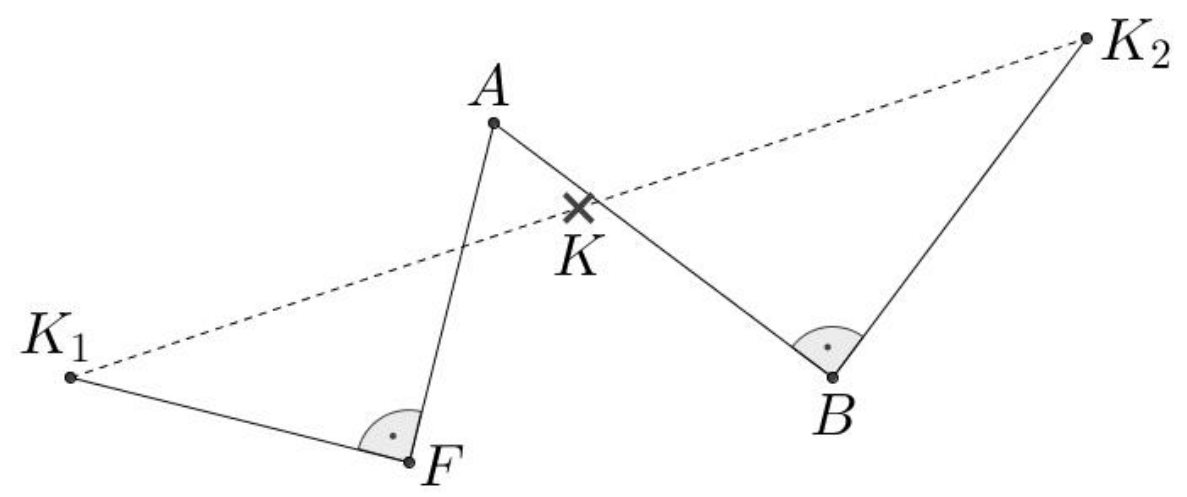

3.2. ábra. A feladat geometriai modellje

Mivel $m\left(\widehat{A F K_{1}}\right)=90^{\circ}$ és $A F=F K_{1}$, ezért

$$
k_{1}-f=(a-f) i \Longleftrightarrow k_{1}=f+(a-f) i .
$$

Hasonlóan $m\left(\widehat{A B K_{2}}\right)=90^{\circ}$ és $A B=B K_{2}$, így

$$
a-b=\left(k_{2}-b\right) i \Longleftrightarrow k_{2}=(1+i) b-a i .
$$

Ekkor

$$
k=\frac{k_{1}+k_{2}}{2}=\frac{(1-i) f+(1+i) b}{2},
$$

ami valóban azt jelenti, hogy a kincs nem függ az akasztófa helyétől, csak a barlangétól és a forrásétól, tehát tetszőleges helyen fölvéve az $A$ pontot, a megadott eljárást végrehajtva, megtalálható a kincs.

Ha mindenféle eljárás nélkül, egészen pontosan meg szeretnénk határozni a kincs helyét, akkor kissé átalakítva a $k$-ra kapott összefüggést, rögtön kiderül, hogy az a barlang és a forrás helyéhez képest hol található. 
Valóban,

$$
k=\frac{(1-i) f+(1+i) b}{2}=\frac{b+f+i(b-f)}{2}=\frac{b+f}{2}+i \cdot \frac{b-f}{2},
$$

ami azt jelenti, hogy a $[B F]$ felezőpontjától, a $B F$-re merőlegesen kimérjük $[B F]$ felét, és ott a kincs.

Mivel a $[B F]$ felezőmerőlegesén két ilyen pontot is van, ezért a kapitánynak esetleg két helyen is kell ásnia, de megtalálja a kincset.

2. megoldás. Egy másik nem sokkal különböző megközelítési mód, kísérleti úton annak megsejtése, majd ugyancsak komplex számok segítségével való bizonyítása, hogy az $F K B_{\triangle}$ egyenlő szárú derékszögü (3.3. ábra), ugyanis ez éppen azt jeleni, hogy a kincs a $[B F]$ felezőmerőlegesén helyezkedik el, attól éppen akkora távolságra, mint annak félhossza. Valóban, behelyettesítve a $K$ pont

$$
k=\frac{b+f}{2}+i \cdot \frac{b-f}{2}
$$

affixumát a

$$
b-k=i \cdot(f-k)
$$

összefüggésbe, igaz állításhoz jutunk.

3. megoldás. Az $F K B_{\triangle}$ egyenlő szárú derékszögü háromszög volta geometriai transzformációk segítségével is könnyen igazolható. Mivel a $K_{2}$ pontnak a $B$ pont körüli $90^{\circ}$-os pozitív irányú elforgatása az $A$ pont, majd annak az $F$ pont körüli szintén $90^{\circ}$-os pozitív irányú elforgatása a $K_{1}$ pont, és mivel e két elforgatás szorzata középpontos tükrözés, ezért a tükrözés középpontja a $\left[K_{1} K_{2}\right]$ felezőpontja, azaz a $K$ pont. Ezek után a $B$ pontra alkalmazva e két elforgatás egymásutánját, a $B$ önmaga körüli elforgatása $B$, majd az $F$ körüli elforgatása $B^{\prime}$. (3.3. ábra)

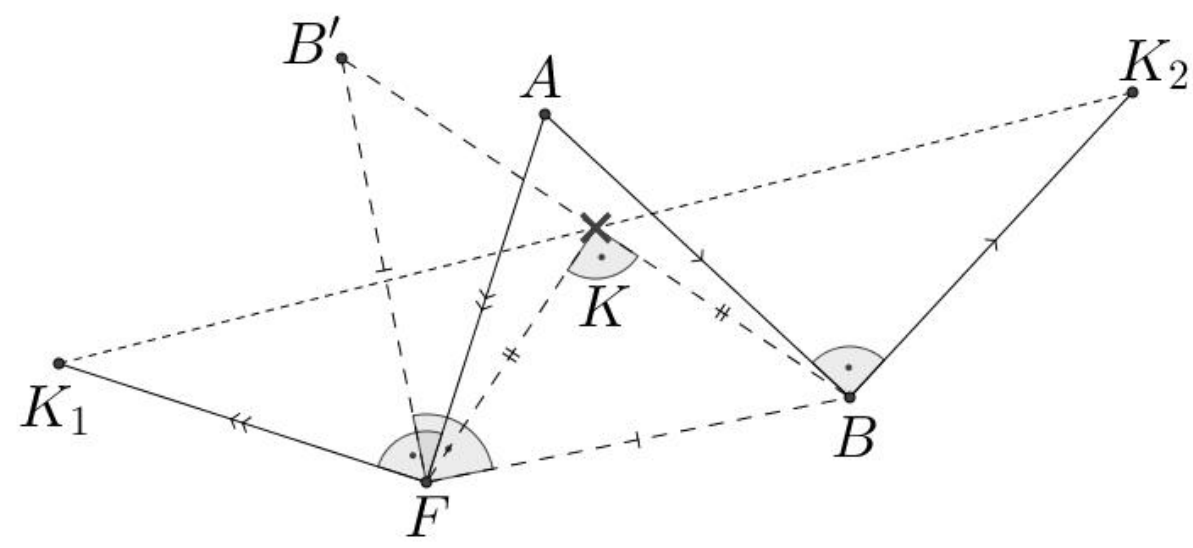

3.3. ábra. A feladat geometriai modellje

De $B^{\prime}$ a $B$ pontnak $K$-ra vonatkozó tükörképe is, mivel a szorzattranszformáció $K$-ra való tükrözés. Így az $B F B_{\triangle}^{\prime}$ és annak fele, az $F K B_{\triangle}$ is egyenlö szárú derékszögü. 
A feladat célja annak fölmérése volt, hogy a diákok mennyire képesek akár több ábrázolási kísérlet útján valamilyen sejtést megfogalmazni, illetve eszükbe jut-e a komplex számok geometriai alkalmazásának hatalmas előnye a sejtés bizonyítása érdekében.

Sajnos sem a középiskolai tanulók, sem az egyetemi hallgatók nem boldogultak kellőképpen a feladattal. Előbbiek közül 7-en, utóbbiak közül csupán 5-ön fogalmaztak meg helyes sejtést, de senkinek sem sikerült bizonyítani azt. Komplex számok bevezetésével senki sem próbálkozott. Ez valószínúleg azzal magyarázható, hogy a komplex számok ilyen szintü geometriai alkalmazása ritkán jelenik meg a középiskolai tananyagban, ezért nem szerepel a diákok aktív eszköztárában. Ugyan tanulták a komplex számok trigonometrikus alakját, ilyen alakban megadott komplex számokkal műveleteket is végeztek (szorzás, osztás, $n$-ed rendü gyökvonás), de mivel ezzel párhuzamosan nem gondolnak minden esetben az eredmény geometriai interpretációjára, így fordított esetben, pl. bizonyításos mértanfeladat esetén, nem természetes azok alkalmazási lehetősége.

A harmadik bizonyítási módszer föl sem merült senkiben, hiszen a geometriai transzformációk nem iskolai tananyag Romániában, így esetleg csak magyarországi versenyekre készülés során, nagyon kevesen találkozhattak azokkal. Az egyetemi hallgatók ugyan tanulták a geometria transzformációkat, de túlságosan elméleti megközelítésben ahhoz, hogy néhányukat leszámítva konkrét feladat kapcsán használni tudnák azokat.

\begin{tabular}{l|c|c} 
& Középiskolás tanuló & Egyetemi hallgató \\
\hline Teljes, helyes megoldás & $0 / 23 \approx 0 \%$ & $0 / 24 \approx 0 \%$ \\
\hline \hline Jó sejtés bizonyítás nélkül & $7 / 23 \approx 30,43 \%$ & $5 / 24 \approx 20,83 \%$ \\
\hline Komplex számok alk. gondolata & $0 / 23 \approx 0 \%$ & $0 / 24 \approx 0 \%$ \\
\hline \hline Transzformációk alk. gondolata & $0 / 23 \approx 0 \%$ & $0 / 24 \approx 0 \%$ \\
\hline \hline Sejtés sincs & $16 / 23 \approx 69,57 \%$ & $19 / 24 \approx 79,17 \%$
\end{tabular}

Néhány gondolat a diákok dolgozataiból:

„,Nem értem a feladatot. A kérdés az lenne, hogy a kapitány 20 év múlva hogyan méri ki a $\left[K_{1} K_{2}\right]$ felezőpontját, ha nincs meg az akasztófa? ... Újra elolvasom a feladatot figyelmesebben."

"Szerintem nem találhatja meg a kincset, mivel nem tudja meghatározni a $K_{1}$-et és $K_{2}$-t."

„,Mivel két egyenlő szárú derékszögü háromszög van, a hasonlóság jutott eszembe, de nem jó semmire sem."

„,Ha $A$-t ismeretlennek tekintjük, legyen tetszőleges, és elkezdjük folyamatosan mozgatni, akkor a kincs helye is folyamatosan változik."

„,Hát most egészen rosszul érzem magam, hogy ezt a feladatot nem tudom megoldani harmadéves matematika szakos hallgatóként."

„Több ábrát is készítettem, és az a sejtésem, hogy akárhova kerül az akasztófa, a kincs egy bizonyos egyenes mentén fog elhelyezkedni, de nem tudom, hogy pontosan hol."

„A kincs, a barlang és a forrás egy derékszögü háromszöget alkot."

,Ez a feladat érdekesebbnek tűnik, mint a többi, ezért ezzel kezdem. ... Az ábráim alapján azt sejtem, hogy a kincs ugyanolyan távol van a barlangtól, mint a forrástól, ezért a kapitány csak a $[B F]$ felezőmerőlegesét kell végigássa. De ezt nem tudom bizonyítani."

„,Kipróbáltam, hogy az $A$-nak a helye változtatja-e a kincs pozícióját. Ahogy látom, nem befolyásolja a kincs megtalálását, csak nem tudom bizonyítani. De biztos, hogy a $K$ a $[B F]$ felezőpontjára húzott merőlegesen van $B F / 2$ távolságra tőle." 


\subsection{A fejlesztés céljai és módszere}

Az előmérés eredményeiből kiderült, hogy úgy a középiskolás diákok, mint az egyetemi hallgatók eszköztára meglehetősen hiányos az olyan matematikai problémák megoldását illetően, ahol az a probléma kijelentésétől eltérő, más reprezentációban való gondolkodást igényel, vagy a más területen való okoskodás egyszerübb, átláthatóbb a szövegezés adta kézenfekvő megoldásmódnál.

Ugyanakkor az is megfigyelhető, hogy még azok a diákok is, akikben megszületik a probléma egy más szemszögből való megközelítésének gondolata, több esetben nem tudják kivitelezni a teljes megoldást, ami az adott területre vonatkozó ismerethiányra utal.

Mindemellett, mivel többüknek semmilyen tapasztalatuk nincs nem standard, az osztályszintű feladatoktól eltérő problémák megoldásában, még a feladat megoldására (eredményére) vonatkozó valamilyen sejtés megfogalmazása is nehézséget jelent.

\subsubsection{A fejlesztés céljai}

A megfigyelések alapján a következő célokat fogalmaztam meg a fejlesztő foglalkozásokra vonatkozóan:

- a problémamegoldás lépéseinek tudatosítása

- általános heurisztikus eljárások, stratégiák tanítása problémamegoldás útján

- a transzformációelv mint általános heurisztikus eljárás alkalmazása

- a különböző tananyagrészek összekapcsolása egy probléma megoldása során

- az analógiákban való gondolkodás fejlesztése

- kísérletezés alapján történő sejtések megfogalmazásának elősegítése, gyakorlása

- különbözö reprezentációkban való gondolkodásra nevelés a feladat szövegezésének mélyrehatóbb vizsgálata által; az „árulkodó jelek” megfigyelésére való érzékenység kialakítása és fejlesztése

- vizuális problémareprezentációk készítése, elemzése

- az egyes objektumok struktúráját legjobban szemléltető reprezentációk kiválasztásának felismerése

- többféle megoldási lehetőség keresése

- új problémák megfogalmazása egy adott reprezentáción történő módosítással, reprezentációváltással 


\subsubsection{A fejlesztés módszere}

Úgy a középiskolás diákok, mint az egyetemi hallgatók számára három hónapon keresztül, heti másfél órás fejlesztő foglalkozást tartottam tanítás utáni szakkör formájában.

Minden foglalkozáson körülbelül 12-15 diák vett részt, tehát két-két szakkör zajlott egymás után középiskolásoknak, illetve egyetemistáknak egyaránt.

A diákok a foglalkozásokon inkább párban, néha 3-4 fös kiscsoportokban dolgoztak. Igyekeztem elősegíteni az önálló felfedezést, így közvetlenül a probléma kitűzése után semmilyen segítséget nem adtam a megoldásra vonatkozóan. Segítő kérdésekkel, ötletekkel csak azután avatkoztam be, ha már teljesen elakadtak, és ők igényelték a segítséget.

Minden foglalkozás végén az aktuális téma elmélyítése érdekében önálló megoldásra szánt házi feladatot kaptak a diákok, melyeket a következő foglalkozáson mindig megbeszéltünk.

A fejlesztő foglalkozások alatt a következő témákat érintettük:

- geometriai úton megoldható algebrai szélsőérték-feladatok

- analitikus geometriai eszközökkel megoldható algebrai egyenletek, egyenlőtlenségek és egyenletrendszerek

- trigonometrikus úton megoldható egyenletek és egyenletrendszerek

- geometria feladatok algebrai úton, koordinátageometriai eszközökkel való megoldása

- komplex számok geometriai alkalmazásai

- függvény értelmezési tartományának és értékkészletének vizsgálatával megoldható egyenletek és egyenletrendszerek

- függvény monotonitási és konvexitási tulajdonságának felhasználásával megoldható egyenletek és egyenletrendszerek

- fixponttal rendelkező függvények segítségével megoldható egyenletek és egyenletrendszerek

- geometriai szélsőérték-problémák algebrai, ill. függvénytani megoldása

- a matematikai analízis elemeinek felhasználása algebrai problémák megoldásában 


\section{4. fejezet}

\section{A fejlesztés folyamata és értékelése}

Ebben a fejezetben a két mérés között lezajlott fejlesztő foglalkozások anyagát mutatom be tematikus bontásban. Minden témakör esetén részletesen ismertetem néhány jellegzetes probléma feldolgozását abban a szellemben, ahogy az a foglalkozáson megvalósult, majd a házi feladatnak szánt problémákat sorolom fel, a legtöbb esetben kitérek azok részletes megoldására is.

A diákok minden foglalkozás elején megkapták az aznapi feladatokat anélkül, hogy közöltem volna, hogy azok milyen témakörbe tartoznak. Mivel nem titkolt szándékom volt a felfedeztető módszer alkalmazása, a tanulók először mindenféle segítség nélkül próbálkoztak a feladatok megoldásával. A nehezebbnek bizonyuló problémák esetén viszont a diákok kérésére rávezető kérdések, ötletek mentén együtt dolgoztunk. Ezen segítő kérdések és ötletek mentén mutatom most be a foglalkozásokon megoldott problémákat.

Az órák során ugyancsak ösztönöztem a diákokat az egyes feladatok többféle irányból való megközelítésére, többféle megoldási módszer keresésére, esetleg ezek ötvözésére. Minden olyan feladat megoldása után, amelyre többféle megoldás is született, megbeszéltük, hogy melyik módszer hatékonyabb, eredményesebb, mutatja jobban a probléma szerkezetét, és melyik munkásabb, kevésbé célszerü az adott feladat esetén. Emellett, amennyire lehetett, bátorítottam a diákokat, hogy maguk is fogalmazzanak meg hasonló szerkezetü problémákat. Esetenként ilyen általuk szerkesztett feladatokat is bemutatok.

A feldolgozott témakörök három fö stratégia köré szerveződtek:

1. Algebrai kijelentés - geometriai megoldás

Szintetikus, analitikus és trigonometrikus megoldásmódok

2. Geometriai kijelentés - algebrai megoldás

A Descartes-féle koordináta-rendszer felhasználása

A Gauss-féle komplex számsík alkalmazása

3. Alkalmas függvény bevezetése

Elemi függvények tulajdonságainak felhasználása

A matematikai analízis elemeinek alkalmazása 


\subsection{Algebrai problémák geometriai reprezentációi}

$\mathrm{Az}$ első stratégiát algebrai szövegezésű feladatok, konkrétan egyenletek, egyenlőtlenségek, egyenletrendszerek és szélsőérték-problémák megoldásának, különböző algebrai összefüggések bizonyításának a tanórákon megszokott tipikus módszerektől eltérő, más szemléletmódja révén kívántam bemutatni, elmélyíteni.

Célom az volt, hogy a diákok algebrai szövegezésű problémák láttán is képesek legyenek aktivizálni mértantudásukat, a geometria szemüvegén keresztül is képesek legyenek tanulmányozni egy algebrai problémát, hiszen bizonyos esetekben az ilyen megközelítésmód eredményesebb a tanórákon begyakorolt és reflexszerűen alkalmazott megoldási módszereknél. Például nem standard algebrai problémák esetén gyakran célravezető, nyerő stratégiai jellegü ötlet, valamilyen vizuális modell készítése, és a probléma geometriai úron való tárgyalása.

Természetesen egy jó vizuális modell megtalálása nem könnyü, sőt néha még annak megléte sem biztosíték a probléma helyes megoldásához, de mindenképpen elönyös, ha a diákok jártasságot szereznek ilyen modellek készítésében és alkalmazásában.

Mi olyan modellek készítésével foglalkoztunk, amelyek valamilyen algebrai szövegezésü feladat szintetikus-, analitikus-, vektorgeometriai vagy éppen trigonometriai megoldásmódját segítik elő. A feladatok többségénél általában, ha található a geometria egyik területén való tárgyalásmódot lehetővé tevő modell, akkor készíthető más területen való okoskodást lehetővé tevő modell is. Például kis módosítással a szintetikus geometriai megoldásmódok mind átvihetők a derékszögű koordináta-rendszerbe, ami nem meglepő hiszen az adott problémák pont emiatt tárgyalhatók úgy algebrai, mint geometriai úton. A kérdés csupán az, hogy melyik elönyösebb.

\subsubsection{Szintetikus geometria}

Amikor a feladat szövegezésében valamilyen geometriai objektum hosszára, területére vagy térfogatára vonatkozó összefüggéshez hasonló kifejezések jelennek meg „gyanút foghatunk". Természetesen ezek felismerése megfelelő mennyiségü matematikai ismeretet, és azok között megfelelő minőségü kapcsolatrendszert feltételez.

Néhány tipikus, a problémák szövegében gyakran előforduló „árulkodó jel”:

- $\sqrt{x^{2}+y^{2}}$ - téglalap átlójának, derékszögü háromszög átfogójának hossza

- $x \sqrt{2}$ - négyzet átlójának, egyenlő szárú derékszögü háromszög átfogójának hossza

- $\sqrt{x^{2}-y^{2}}$ - derékszögü háromszög egyik befogójának hossza

- $x^{2}+y^{2} \pm x y$ - háromszög valamely oldalhosszának négyzete

- $A \pm B \cdot \cos \alpha$ vagy $A \pm B \cdot \sin \alpha$ - háromszög valamelyik oldalhosszának négyzete

- $\sqrt{x^{2}+y^{2}+z^{2}}$ - téglatest testátlójának hossza

- $x \sqrt{3}$ - kocka testátlójának hossza

- $x \cdot y$ - téglalap területe

- $x \cdot y \cdot z$ - téglatest térfogata 


\section{Órán megoldott feladatok}

4.1.1. Feladat. Igazold, hogy bármely $a, b, c \in \mathbb{R}$ szám esetén

$$
\sqrt{a^{2}+b^{2}}+\sqrt{b^{2}+c^{2}}+\sqrt{c^{2}+a^{2}} \geq(a+b+c) \sqrt{2} .
$$

\section{Kérdések:}

- Mire emlékeztet az egyenlőtlenség jobb oldala? Hol jelenik meg ilyen $x \sqrt{2}$ alakú kifejezés?

- Hát a bal oldali gyökök? Hol találkoztál már $\sqrt{x^{2}+y^{2}}$ alakú kifejezéssel?

- Hogyan jeleníthetők meg ezek? Össze tudnád-e kapcsolni az összeset egyetlen ábrán?

- Mi olvasható le erről az ábráról?

- Mit jelent az egyenlőtlenség geometriailag? Mikor áll fenn egyenlőség?

- Minden $a, b, c$ valós szám esetén jól írja le a modell az egyenlőtlenséget? Mi történik negatív számok esetén?

- Ugyanezen modell alapján meg tudnál-e fogalmazni más állításokat? Tudnál alkotni hasonló egyenlőtlenségeket?

- Hasonló, de más modell esetén meg tudnál-e fogalmazni hasonló jellegű állításokat?

Megoldás: Ha $a, b, c$ pozitív számok, akkor a jobb oldali kifejezés egy $a+b+c$ oldalhosszúságú négyzet átlója lesz, míg a bal oldali gyökök egy-egy téglalap átlóinak hosszai. Így szerkeszthetünk egy olyan geometriai modellt, amelyen az egyenlőtlenségben szereplő gyökkifejezések szakaszok hosszaiként jelennek meg.

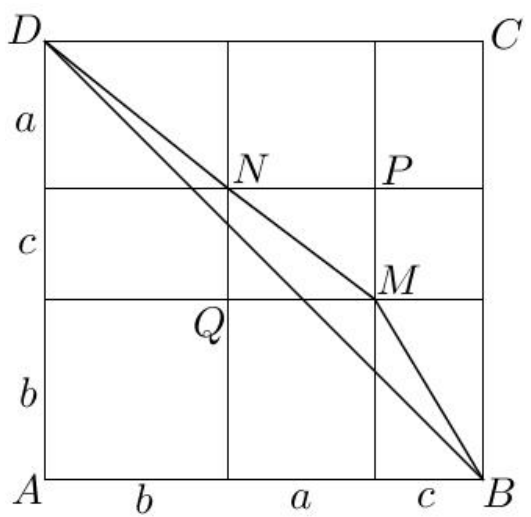

4.1. ábra. Az egyenlőtlenség geometriai modellje

A 4.1. ábra alapján

$$
B M=\sqrt{b^{2}+c^{2}}, M N=\sqrt{a^{2}+c^{2}}, N D=\sqrt{a^{2}+b^{2}} \text { és } B D=(a+b+c) \sqrt{2} .
$$

Világos, hogy $B M+M N+N D \geq B D$, ami éppen a bizonyítandó egyenlőtlenség. 
Ha az $a, b, c$ számok valamelyike negatív, például $c<0$, akkor az $a, b,-c$ értékekre szerkesztjük a modellt, és ekkor

$$
\sqrt{a^{2}+b^{2}}+\sqrt{b^{2}+c^{2}}+\sqrt{c^{2}+a^{2}} \geq(a+b-c) \sqrt{2} \geq(a+b+c) \sqrt{2} .
$$

Tehát az egyenlőtlenség bármilyen $a, b, c$ valós szám esetén igaz, és egyenlőség csak $a=b=c$ esetén áll fenn.

Megjegyzés: A diákok további modelleket és ezekhez kapcsolódó egyenlőtlenségeket javasoltak:

1.) A 4.2. ábra alapján

$$
\begin{gathered}
B P+P D \geq B D \Longleftrightarrow \sqrt{c^{2}+(b+c)^{2}}+\sqrt{a^{2}+(a+b)^{2}} \geq(a+b+c) \sqrt{2} \Longleftrightarrow \\
\sqrt{b^{2}+2 b c+2 c^{2}}+\sqrt{2 a^{2}+2 a b+b^{2}} \geq(a+b+c) \sqrt{2}
\end{gathered}
$$

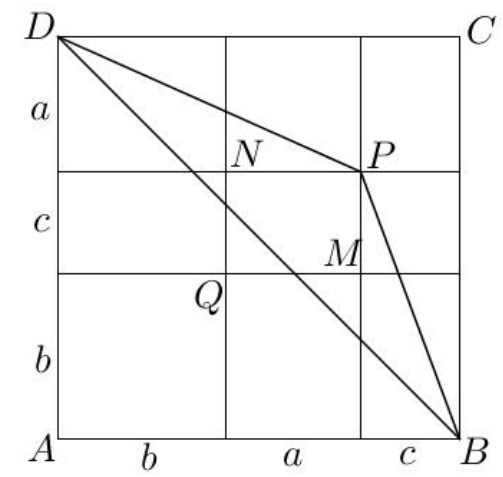

4.2. ábra.

2.) A 4.3. ábra alapján

$$
A Q+Q P+P C \geq A C \quad \Longleftrightarrow \quad \sqrt{2 b^{2}}+2 \sqrt{a^{2}+c^{2}} \geq(a+b+c) \sqrt{2}
$$

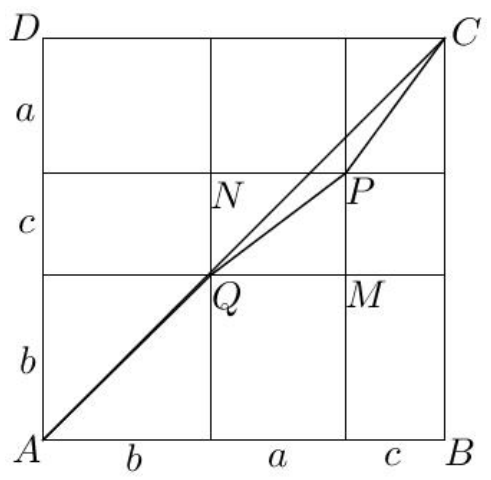

4.3. ábra. 
4.1.2. Feladat. Igazold, hogy bármely $a_{i}, b_{i} \in \mathbb{R}, i \in\{1,2, \ldots, n\}$ esetén

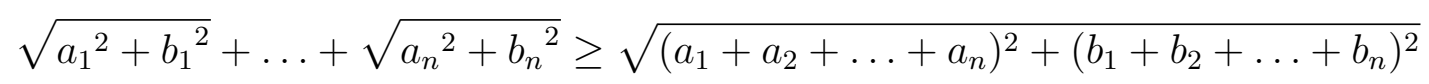

\section{Kérdések:}

- A bal oldali gyökkifejezések már ismerösek. De minek az algebrai leírása lehet a jobb oldali gyök?

- Össze tudnád kapcsolni egy modellen az összes információt?

- A kapott ábra alapján mikor áll fenn egyenlőség?

- El tudod képzelni a kapott modell térbeli változatát?

- Mi lenne a síkbeli egyenlőtlenség térbeli megfelelője?

Megoldás: Az egyenlőtlenség bal oldala $n$ darab kis téglalap átlójának összhossza, ami töröttvonalként képzelhető el. A jobb oldal egy olyan nagy téglalap átlójának hossza, amelyik ilyen kis téglalapokból áll.

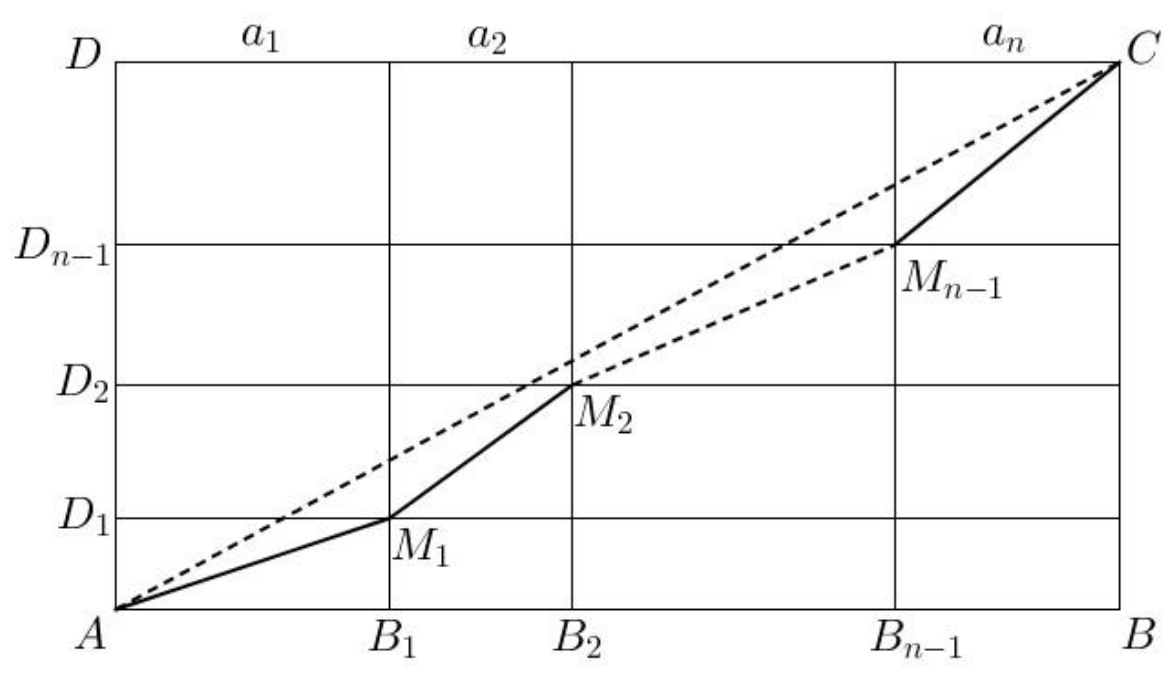

4.4. ábra. A sokszög-egyenlőtlenség

Mindezek megjelenítése érdekében - a 4.4. ábrának megfelelően - vegyünk fel egy olyan $A B C D$ téglalapot, amelynek oldalait az $A B_{1}=a_{1}, B_{1} B_{2}=a_{2}, \ldots, B_{n-1} B=a_{n}$, valamint az $A D_{1}=b_{1}, D_{1} D_{2}=b_{2}, \ldots, D_{n-1} D=b_{n}$ különböző hosszúságú szakaszok alkotják, majd húzzunk a téglalap oldalaival párhuzamos egyeneseket a $B_{i}, D_{i}$ pontokon keresztül. Így $n^{2}$ kis téglalap keletkezik.

Ekkor az egyenlőtlenség bal oldala az $\left[A M_{1} M_{2} \ldots M_{n-1} C\right]$ töröttvonal hossza, míg a jobb oldal az $A C$ átló hossza, ami nyilvánvalóan nem nagyobb az említett töröttvonal összhosszánál. Egyenlőség pontosan akkor áll fenn, amikor $\frac{a_{i}}{b_{i}}=\frac{A B}{A D}, \forall i \in\{1,2, \ldots, n\}$.

A térbeli modell alapján előálló analóg egyenlőtlenség a 4.1.9. házi feladat.

Megjegyzés: Míg a diákok az első feladattal eleinte nehezen boldogultak, ezt a feladatot már szinte mindenki tökéletesen meg tudta oldani segítség nélkül, sőt a térbeli megfelelőjére is könnyen rájöttek. Nehézség inkább az egyenlőség fennállásának helyes megállapításában mutatkozott. 
4.1.3. Feladat. Igazold, hogy $\forall a, b, c \in \mathbb{R}_{+}$számok esetén

$$
\sqrt{a^{2}+b^{2}-a b \sqrt{3}}+\sqrt{b^{2}+c^{2}-b c \sqrt{3}}+\sqrt{a^{2}+c^{2}-a c \sqrt{3}} \geq a \sqrt{2}
$$

\section{Kérdések:}

- Most a jobb oldali kifejezések ismerős. Minek az algebrai leírásai lehetnek a bal oldali gyökkifejezések?

- Ha egy derékszögű háromszögben a Pitagorasz-tétel alapján az átfogó hossza $\sqrt{x^{2}+y^{2}}$, melyik metrikus összefüggésben jelenik meg $x^{2}+y^{2}-x y$ vagy $\sqrt{x^{2}+y^{2}-x y}$ alakú kifejezés?

- Össze tudnád kapcsolni a kapott információkat egy modellen?

- Meg tudnád állapítani, hogy mikor áll fenn egyenlőség?

Megoldás: A jobb oldali kifejezés egy a oldalú négyzet átlója, vagy egy a befogójú egyenlő szárú derékszögű háromszög átfogója. A bal oldali gyökök alatt egy-egy koszinusztétel formájú kifejezés van, ahol a megfelelő oldalak által bezárt szög mindhárom esetben $30^{\circ}$. Felrajzolva a közös kezdőpontú $a, b, c, a$ hosszúságú szakaszokat, melyek egymással rendre $30^{\circ}$-os szöget zárnak be, a 4.5. ábrát kapjuk.

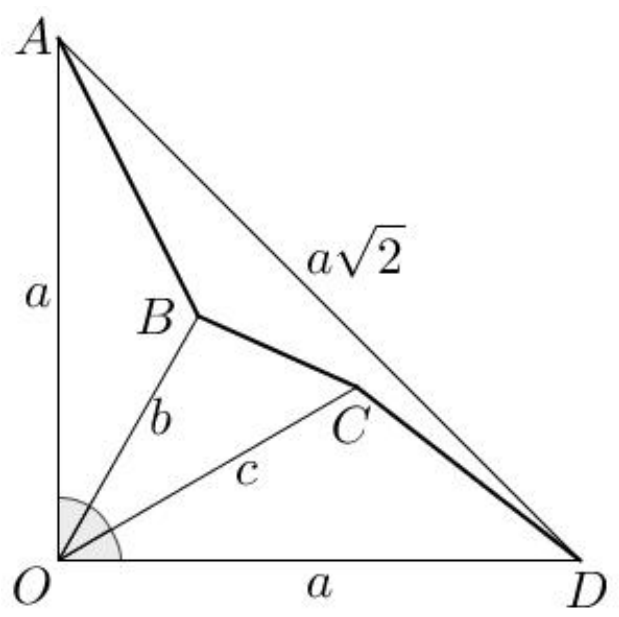

\section{5. ábra. Koszinusztétel}

Ekkor az $[A B C D]$ töröttvonal hossza nem kisebb az $A D$ átfogó hosszánál, ami éppen a kért egyenlötlenség. Egyenlőség $b=c=(\sqrt{3}-1) a$ esetén áll fenn.

Megjegyzés: Arra, hogy a gyökök alatt a koszinusztételben szereplő kifejezések vannak, így azok valamilyen szakaszok hosszai, a diákok kis segítséggel rájöttek. Az információk egy ábrán való elhelyezése, tehát a célszerü modell megtalálása, már sokkal nagyobb problémát okozott. Tudták, hogy az egyes szakaszok rendre $30^{\circ}$-os szöget kell bezárjanak, de hogy egy közös kezdőpontba, és pont ilyen sorrendbe helyezzék őket, már keményebb diónak bizonyult. Ebben a korábbi két feladat sem segített, hiszen azoknál téglalaprácson dolgoztak. Viszont annál nagyobb volt az öröm, amikor összeállt a továbbvezető modell, így a diákok egyértelmüen pozitívan értékelték a feladatot. 
4.1.4. Feladat. Igazold, hogy $\forall x, y, z, t \in[0,1]$ esetén

$$
x(1-t)+y(1-x)+z(1-y)+t(1-z) \leq 2 .
$$

\section{Kérdések:}

- Hogyan jeleníthető meg geometriailag az $a \cdot b$ szorzat? Milyen alakzat mely jellemzőjének a méröszáma lehet?

- Mire utalhat, hogy nem $a \cdot b$, hanem $a \cdot(1-b)$ alakú szorzatok szerepelnek?

- Tudnál készíteni olyan modellt, amelyen több ilyen terület jelenik meg egyszerre?

- Ha a talált modell nem a legátláthatóbb, tudnál módosítani a feladat kijelentésén, és annak megfelelő vizuális modellt gyártani?

- Meg tudnád állapítani, hogy mikor áll fenn egyenlőség?

Megoldás: A jobb oldali szorzatok geometriailag bizonyos téglalapok területeinek felelnek meg. Mivel $a \cdot(1-b)$ alakú szorzatok szerepelnek az egyenlőtlenségben, ezért egy egység oldalú négyzet oldalain fogjuk fölvenni a feladat kijelentésében megjelenő értékeket.

Tekintsük az $A B C D$ egységnyi oldalú négyzet $A B, B C, C D, D A$ oldalain rendre az $M, N, P, Q$ pontokat úgy, hogy $A M=x, B N=y, C P=z, D Q=t$ (4.6. ábra).

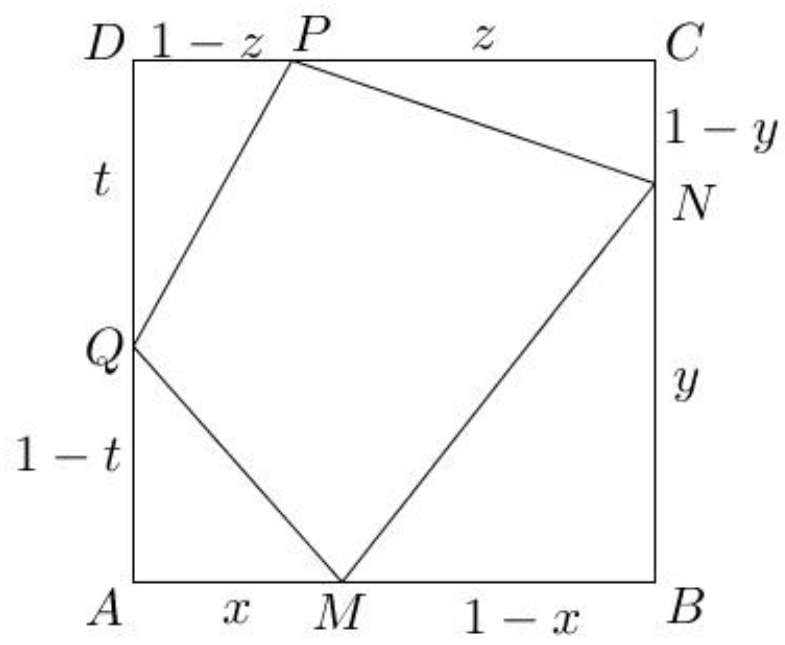

4.6. ábra. Területek

Mivel a keletkezett téglalapok területei átfedik egymást, nehezen látható, hogy az összterületük nem haladja meg a 2 területegységet, azaz kettőnél többször nem fedik le a négyzetet. Ezért érdemes leosztani az egyenlőtlenség mindkét oldalát 2-vel, és háromszögek területében gondolkodni. Ekkor

$$
T_{A M Q}+T_{B M N}+T_{C N P}+T_{D Q P} \leq T_{A B C D}
$$

azaz

$$
\frac{x(1-t)}{2}+\frac{y(1-x)}{2}+\frac{z(1-y)}{2}+\frac{t(1-z)}{2} \leq 1,
$$


ahonnan

$$
x(1-t)+y(1-x)+z(1-y)+t(1-z) \leq 2 .
$$

Egyenlöség $(x, y, z, t) \in\{(1,0,1,0),(0,1,0,1)\}$ esetén áll fenn.

Észrevehető ugyanakkor, hogy $x=y=z=t=\frac{1}{2}$ esetén a háromszögek csupán a négyzet felét fedik le, tehát az egyenlőtlenség meglehetősen durva.

Megjegyzés: Az egyenlőtlenségnek megfelelő modell megtalálása nem volt könnyü feladat sem a középiskolás diákok, sem pedig az egyetemi hallgatók számára. A nehézséget az egység oldalú négyzetben való gondolkodás és oldalainak felosztása jelentette. Miután kis segítséggel megszületett az első modell, tovább már könnyen okoskodtak magukra a diákok, sőt néhányan közülük a jobb átláthatóság érdekében, javasolták az egyenlőtlenség végigosztását 2 -vel, és téglalapok helyett, háromszögek területében való gondolkodást. Az egyenlöség fennállásának kikísérletezése sem okozott gondot.

4.1.5. Feladat. Oldd meg az alábbi egyenletet a $\left(0, \frac{\pi}{2}\right)$ intervallumon!

$$
\sqrt{15-12 \cos x}+\sqrt{7-4 \sqrt{3} \sin x}=4
$$

\section{Kérdések:}

- Hogyan állíthatók elő valamilyen szakaszok hosszaiként a bal oldali gyökkifejezések?

- Milyen összefüggés hasonlít konkrét értékek esetén a gyökök alatti kifejezésekre? Fel tudnád írni?

- Tudnál készíteni olyan vizuális modellt, amelyen egyszerre jelenik meg mindkét gyökkifejezés és a jobb oldal is?

- Hol jelenik meg ekkor az ismeretlen?

- Mit tudsz leolvasni a kapott ábráról?

- Mit jelent az, hogy a két gyök összege egyenlő a jobb oldali számmal?

- Hogyan tudnád meghatározni az ismeretlent?

- Tudnál hasonló feladatot szerkeszteni esetleg más modell alapján?

- Algebrai megoldás esetén, hogy lenne érdemes eljárni?

Geometriai megoldás: A gyökök alatti kifejezések alakja alapján megpróbálhatunk valamilyen geometriai ábrát létrehozni, amelyen szakaszhosszként megjelennek a $\sqrt{15-12 \cos x}$ és a $\sqrt{7-4 \sqrt{3} \sin x}$ kifejezések.

A koszinusztétel alapján elégséges volna olyan $a, b>0$ számokat találni, amelyekre $a^{2}+b^{2}=15$ és $2 a b=12$. Ilyenek az $a=\sqrt{3}$ és $b=2 \sqrt{3}$. Ez azt jelenti, hogy abban a háromszögben, amelyben az $a=\sqrt{3}$ és $b=2 \sqrt{3}$ hosszúságú oldalak szöge $x$, a harmadik oldal hossza pontosan $\sqrt{15-12 \cos x}$.

Hasonlóan, ha az $a=\sqrt{3}$ és $c=2$ hosszúságú oldalak szöge $\frac{\pi}{2}-x$, akkor a harmadik oldal hossza $\sqrt{7-4 \sqrt{3} \cos \left(\frac{\pi}{2}-x\right)}=\sqrt{7-4 \sqrt{3} \sin x}$. Ezeket ábrázoljuk, és megnézzük, hogy mit jelent maga az egyenlet. 
Mivel $x+\frac{\pi}{2}-x=\frac{\pi}{2}$, a két szög egymás pótszöge, így egymás mellé fölvéve az $x$ mértékü, $2 \sqrt{3}$ és $\sqrt{3}$ szárú, valamint a $\frac{\pi}{2}-x$ mértékü, $\sqrt{3}$ és 2 egység szárú szögeket, egy $2 \sqrt{3}$ és 2 egység szárú derékszöget kapunk.

Szerkesszük meg az $A O B$ derékszögü háromszöget úgy, hogy $m(\widehat{A O B})=90^{\circ}, O A=$ $2 \sqrt{3}$ és $O B=2$ legyen. (4.7. ábra)

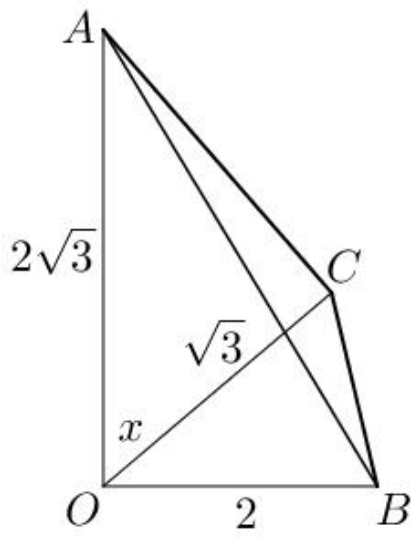

4.7. ábra.

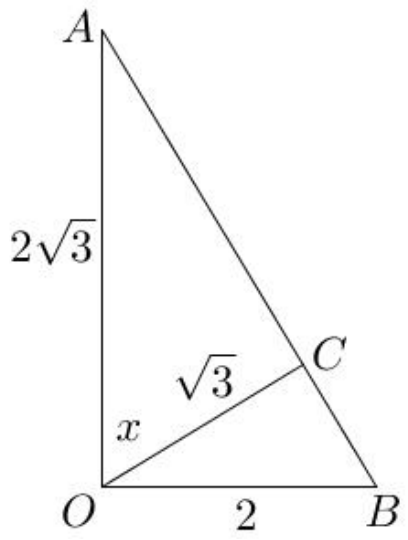

4.8. ábra.

Ekkor $C$ egy olyan pont a síkban, amelyre $m(\widehat{A O C})=x$ és $O C=\sqrt{3}$, így a koszinusztétel alapján

$$
\begin{gathered}
A C=\sqrt{(2 \sqrt{3})^{2}+(\sqrt{3})^{2}-2 \cdot 2 \sqrt{3} \cdot \sqrt{3} \cos x}=\sqrt{15-12 \cos x} \\
B C=\sqrt{2^{2}+(\sqrt{3})^{2}-2 \cdot 2 \cdot \sqrt{3} \cdot \cos \left(\frac{\pi}{2}-x\right)}=\sqrt{7-4 \sqrt{3} \sin x}
\end{gathered}
$$

A Pitagorasz-tétel alapján $A B=\sqrt{(2 \sqrt{3})^{2}+2^{2}}=4$, így az egyenlet szerint

$$
A C+B C=A B .
$$

Ez pontosan akkor teljesül, amikor $C \in(A B)$. (4.8. ábra) Ugyanakkor az $O$-hoz tartozó magasság $h=\frac{2 \cdot 2 \sqrt{3}}{4}=\sqrt{3}$, tehát $C$ az $O$-ból húzott magasság talppontja. De ekkor $m(\widehat{O A C})=30^{\circ}$, így $m(\widehat{A O C})=60^{\circ}$, tehát $x=\frac{\pi}{3}$.

Megjegyzés: Vélhetően a korábbi feladatok gyakorlata miatt, a feladat mögötti modell megtalálása nem okozott különösebb nehézséget a diákoknak. Egyesek ugyan később, de mind rájöttek, hogy az $O C$ magasság, így a sajátos adatok miatt, $x$ értéke könnyen meghatározható. Néhányan más számadatokra ugyan, de tulajdonképpen azonos modellel, teljesen hasonló egyenleteket gyártottak.

Algebrai megoldás: Pusztán algebrai számításokkal is megoldható a feladat, viszont mindenképpen érdemes helyettesíteni, hiszen egyszerü négyzetreemelés esetén nagyon elszaporodnak a tagok, így kevésbé lesz átlátható, követhető a megoldás.

Legyen

$$
A:=\sqrt{15-12 \cos x}
$$


ahonnan viszont

$$
\cos x=\frac{15-A^{2}}{12}
$$

De ekkor a trigonometria alaptétele szerint

$$
\sin x=\frac{\sqrt{\left(A^{2}-3\right)\left(27-A^{2}\right)}}{12} .
$$

Így az egyenlet

$$
A+\sqrt{7-\sqrt{\frac{\left(A^{2}-3\right)\left(27-A^{2}\right)}{3}}}=4
$$

kevésbé szép, de könnyebben kezelhető alakra hozható. Kétszer négyzetre emelve, és közben rendezve kapjuk, hogy

$$
\begin{gathered}
3 \cdot\left[7-(4-A)^{2}\right]^{2}=\left(A^{2}-3\right)\left(27-A^{2}\right) \\
A^{4}-12 A^{3}+54 A^{2}-108 A+81=0 \\
(A-3)^{4}=0
\end{gathered}
$$

ahonnan $A=3$, így $\cos x=\frac{1}{2}$. Az $x \in\left(0, \frac{\pi}{2}\right)$ feltétel alapján $x=\frac{\pi}{3}$.

Megjegyzés: Érdekes módon az algebrai megoldás nem bizonyult egyszerünek. Minden csoportnak volt ugyan úgy irracionális, mint trigonometrikus egyenletek megoldásában némi tapasztalata, de evvel a fajta helyettesítéssel még nem találkoztak. Első nekifutásra általában elkezdték négyzetre emelni, rendezni, majd újra négyzetre emelni az egyenletet, ám a tagok elszaporodása miatt, föladták a módszerük helyességébe vetett hitet. Kis segítséggel viszont már mindenki algebrai úton is megoldotta a feladatot.

4.1.6. Feladat. Határozd meg az $x y+2 y z+3 z x$ kifejezés értékét, ha az $x, y, z$ pozitiv valós számok teljesítik a következö összefüggéseket:

$$
x^{2}+x y+\frac{y^{2}}{3}=25, \quad \frac{y^{2}}{3}+z^{2}=9, \quad z^{2}+z x+x^{2}=16 .
$$

\section{Kérdések:}

- Mihez hasonlítanak a feltételben szereplő összefüggések?

- Meg tudnád-e jeleníteni a három feltételbeli összefüggést egyetlen geometriai modellen? Mit veszel észre?

- A feltételek jobb oldalán levő számadatok mit jelentenek?

- Mit jelent a feladat kérése geometriailag? Hogyan lehet a kéréshez hasonló összefüggéshez jutni az ábra alapján?

- Tudnál esetleg új modell alapján hasonló feladatot alkotni? 
Megoldás: A rendszer megoldása, majd a kapott értékek behelyettesítése a meghatározandó kifejezésbe bonyolultnak tűnik. Mivel az algebrai megoldásmód nagyon nehezen járható út, ezért geometriai úton próbálkozunk. Mindhárom egyenlőség hasonlít a koszinusztételben szereplő kifejezésre. Ábrát készítünk, amelyen szakaszhosszként megjelennek a megadott egyenlőségek, majd vizsgáljuk a kiszámítandó kifejezést.

Mivel

$$
\begin{gathered}
x^{2}+x y+\frac{y^{2}}{3}=x^{2}+\left(\frac{y}{\sqrt{3}}\right)^{2}-2 \cdot x \cdot \frac{y}{\sqrt{3}} \cdot \cos \frac{5 \pi}{6}, \\
\frac{y^{2}}{3}+z^{2}=\left(\frac{y}{\sqrt{3}}\right)^{2}+z^{2}-2 \cdot \frac{y}{\sqrt{3}} \cdot z \cdot \cos \frac{\pi}{2}, \\
z^{2}+x z+x^{2}=z^{2}+x^{2}-2 \cdot z \cdot x \cdot \cos \frac{2 \pi}{3},
\end{gathered}
$$

felvesszük az $O A=x, O B=\frac{y}{\sqrt{3}}$ és $O C=z$ szakaszokat úgy, hogy $m(\widehat{A O B})=150^{\circ}$, $m(\widehat{B O C})=90^{\circ}$ és $m(\widehat{C O A})=120^{\circ}$ legyen. (4.9. ábra) Ekkor a koszinusztétel alapján

$$
A B=\sqrt{x^{2}+\frac{y^{2}}{3}+x y}=5, \quad B C=\sqrt{\frac{y^{2}}{3}+z^{2}}=3, \quad A C=\sqrt{z^{2}+x z+x^{2}}=4 .
$$

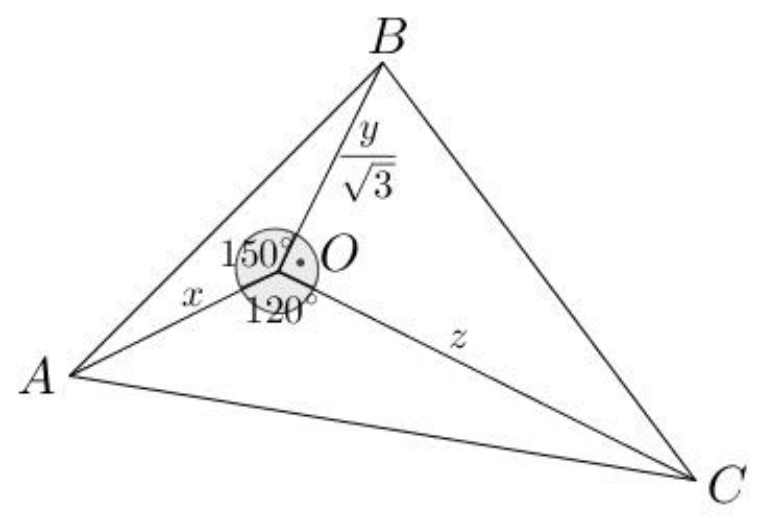

4.9. ábra. A rendszer geometriai jelentése

Mivel $150^{\circ}+90^{\circ}+120^{\circ}=360^{\circ}$, és a $3,4,5$ pitagoraszi számhármas, ezért a keletkezett $A B C$ háromszög derékszögü.

A keresett $x y+2 y z+3 x z$ kifejezés az $A O B, B O C$ és $C O A$ háromszögek területével, pontosabban területösszegével hozható kapcsolatba, ezért kiszámítjuk a nagy $A B C$ háromszög területét kétféleképpen. Egyrészt $T_{A B C}=\frac{3 \cdot 4}{2}=6$, mászrészt

$$
T_{A B C}=T_{O A B}+T_{O B C}+T_{O A C}
$$

azaz

$$
6=\frac{x y}{4 \sqrt{3}}+\frac{2 z y}{4 \sqrt{3}}+\frac{3 x z}{4 \sqrt{3}},
$$

amit beszorozva $4 \sqrt{3}$-mal, kapjuk, hogy

$$
x y+2 y z+3 x z=24 \sqrt{3} .
$$


Megjegyzés: A diákok mind rájöttek, hogy a feltételbeli összefüggések koszinusztételbeliek, viszont néhányan rosszul számították ki a szögeket, így a helyes modellt már nem tudták összeállítani. A hibák kijavítása után már mindenki elkészítette a helyes ábrát. Viszonylag arra is korán rájöttek, hogy a kérés területösszeget takar, és hogy ez a nagy háromszög területének kétféle kiszámításával állítható elő.

A diákoknak kifejezettem tetszett a feladat, így alkottak is hasonló problémákat. Például az egyik ilyen feladat:

Határozd meg az $x y+y z+z x$ kifejezés értékét, ha az $x, y, z$ pozitív valós számok teljesitik az $x^{2}+x y+y^{2}=9, \quad y^{2}+y z+z^{2}=16, \quad z^{2}+z x+x^{2}=25$ összefüggéseket!

4.1.7. Feladat. Igazold, hogy

$$
\sqrt{1008 \cdot 1010}+\sqrt{1007 \cdot 1011}+\ldots+\sqrt{2 \cdot 2016}+\sqrt{1 \cdot 2017}<\frac{1009^{2} \cdot \pi}{4} .
$$

\section{Kérdések:}

- Ha geometriai modellben gondolkodunk, miről árulkodik a jobb oldal? Mihez hasonlít az?

- Hogy tudnád átalakítani az egyenlőtlenség bal oldalát, hogy távolságok, esetleg területek összege jelenjen meg ott?

- Milyen viszonyban vannak az 1009-cel a gyök alatti számok? Hogyan alakíthatók át a gyökök $\sqrt{a^{2}-b^{2}}$, esetleg $\sqrt{1-x^{2}}$ formájúvá?

- Tudnál olyan modellt készíteni, amelyen mind megjelennek a rendelkezésre álló információk? Mit jelent ekkor a bal oldali összeg?

- Általánosan hogy hangzana a feladat?

Megoldás: A jobb oldal valamilyen körön alapuló modellben való gondolkodást sugall, viszont a bal oldali gyökök ilyen formán nehezen jeleníthetők meg, ezért átalakítjuk a gyök alatti szorzatokat. Mivel mindenik gyök alatt $(1009-k)(1009+k)$ szorzat szerepel, minden tag átalakítható gyök alatti négyzetek különbségévé, hiszen

$$
\sqrt{(1009-k)(1009+k)}=\sqrt{1009^{2}-k^{2}} .
$$

Ekkor

$$
\sqrt{1009^{2}-1^{2}}+\sqrt{1009^{2}-2^{2}}+\ldots+\sqrt{1009^{2}-1007^{2}}+\sqrt{1009^{2}-1008^{2}}<\frac{1009^{2} \cdot \pi}{4}
$$

majd az összegből kiemelve 1009-et, és elosztva az egyenlőtlenséget 1009²-nel, kapjuk, hogy

$$
\frac{1}{1009} \sum_{k=1}^{1008} \sqrt{1-\left(\frac{k}{1009}\right)^{2}}<\frac{\pi}{4}
$$

A gyök alatt szereplő kifejezés egy egység sugarú körön alapuló modell megszerkesztését sejteti, míg a jobb oldal éppen egy egység sugarú negyedkör területével egyenlő. 
Tekintsünk egy ilyen negyed körlemezt, majd szeleteljük föl 1009 egyforma széles vékony sávra! (4.10. ábra) Legyen

$$
\begin{gathered}
R=O A=O B=O B_{k}=1, \quad \forall k \in\{1,2, \ldots, 1008\} \\
O A_{1}=A_{k-1} A_{k}=A_{1008} A=\frac{1}{1009}, \quad O A_{k}=\frac{k}{1009}, \quad \forall k \in\{2, \ldots, 1008\} .
\end{gathered}
$$

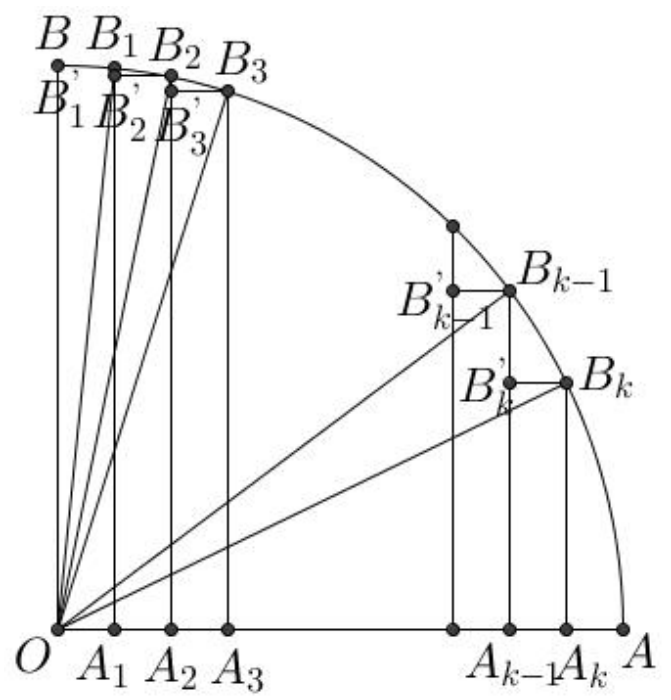

4.10. ábra. A negyedkör-modell

Azonban az $O A B$ negyedkörbe írt téglalapok területösszege kisebb a negyedkör területénél, vagyis

$$
T_{O A_{1} B_{1} B_{1}^{\prime}}+T_{A_{1} A_{2} B_{2} B_{2}^{\prime}}+\ldots+T_{A_{k-1} A_{k} B_{k} B_{k}^{\prime}}<T_{O A B}=\frac{\pi}{4},
$$

és mivel a Pitagorasz-tétel alapján

$$
A_{k} B_{k}=\sqrt{1^{2}-O A_{k}^{2}}=\sqrt{1-\left(\frac{k}{1009}\right)^{2}},
$$

ezért

$$
T_{A_{k-1} A_{k} B_{k} B_{k}^{\prime}}=A_{k-1} A_{k} \cdot A_{k} B_{k}=\frac{1}{1009} \cdot \sqrt{1-\left(\frac{k}{1009}\right)^{2}},
$$

így következik, hogy

$$
\frac{1}{1009} \sum_{k=1}^{1008} \sqrt{1-\left(\frac{k}{1009}\right)^{2}}<\frac{\pi}{4}
$$

Általánositás: Ha nem 1009, hanem $n \in \mathbb{N}^{*}$ kicsi sávra osztjuk a negyed körlapot, akkor

$$
\frac{1}{n} \sum_{k=1}^{n-1} \sqrt{1-\left(\frac{k}{n}\right)^{2}}<\frac{\pi}{4}
$$


ahonnan $\forall n \in \mathbb{N}^{*}$ esetén

$$
\sqrt{(n-1) \cdot(n+1)}+\sqrt{(n-2) \cdot(n+2)}+\ldots+\sqrt{2 \cdot(2 n-2)}+\sqrt{1 \cdot(2 n-1)}<\frac{n^{2} \cdot \pi}{4} .
$$

Söt, ha $n \rightarrow+\infty$, akkor

$$
\lim _{n \rightarrow \infty} \frac{1}{n} \sum_{k=1}^{n-1} \sqrt{1-\left(\frac{k}{n}\right)^{2}}=\int_{0}^{1} \sqrt{1-x^{2}} d x=\frac{\pi}{4}
$$

Megjegyzés: Ezzel a feladattal önállóan már nem boldogultak a diákok, így a kérdések mentén végig együtt dolgoztunk. Ez várható volt, hiszen a középiskolások csak 12. osztályban, a Riemann-integrál bevezetésekor találkoznak ilyen típusú összegekkel. Az egyetemisták viszont, ismerős módszer lévén, már aktívabban tudták követni a megoldást.

4.1.8. Feladat. Határozd meg az $f: \mathbb{R} \rightarrow \mathbb{R}, f(x)=\sqrt{a^{2}+x^{2}}+\sqrt{(b-x)^{2}+c^{2}}$ függvény minimumát, ha a, b, c rögzített pozitív számok!

\section{Kérdések:}

- Mire emlékeztetnek a leképezési törvényben szereplő gyökkifejezések?

- Hogyan lehetne megjeleníteni ezeket? Mit jelentenek ekkor a függvényértékek?

- Meg tudnád jeleníteni a kapott modellen a minimumot?

- Mikor, milyen $x$ esetén következik ez be? Mennyi az értéke?

Megoldás: Mivel a feladatban szereplő gyökök távolságokat jelentenek, ezért geometriailag közelítjük meg a problémát. A 4.11. ábra jelöléseit használva, legyen $A A^{\prime}=a$, $C C^{\prime}=c, A C=b$ úgy, hogy $A A^{\prime} \perp A C, C C^{\prime} \perp A C$, és $P$ az $A C$-n tetszőlegesen mozgó pont. Legyen $A P=x$. Ekkor $A^{\prime} P=\sqrt{a^{2}+x^{2}}$ és $C^{\prime} P=\sqrt{(b-x)^{2}+c^{2}}$.

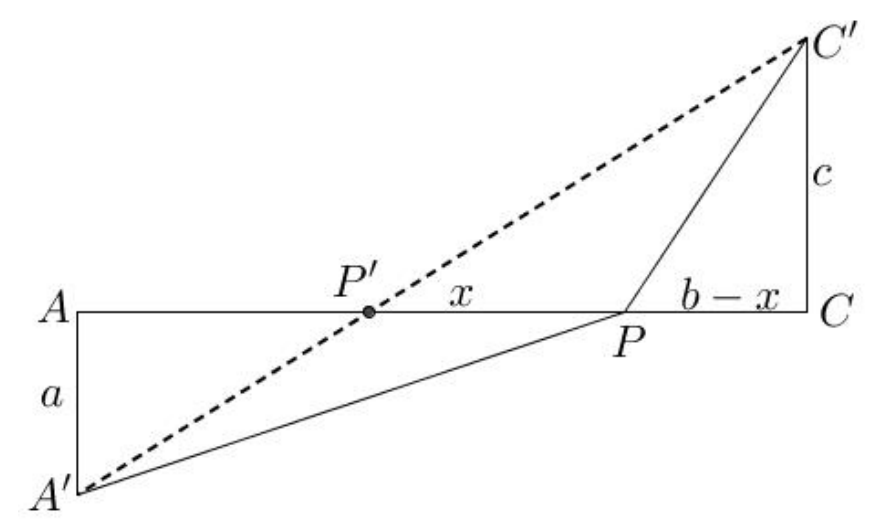

4.11. ábra. A függvényértékek geometriai jelentése

Kérdés, hogy a $P$ pont mely helyzete esetén lesz az $A^{\prime} P+C^{\prime} P$ minimális. Nyilván akkor, ha $A^{\prime}, P$ és $C^{\prime}$ egy egyenesre esnek. Ekkor $P$ a $P^{\prime}$-be kerül, és az $A A^{\prime} P_{\triangle}^{\prime}$ és $C C^{\prime} P_{\triangle}^{\prime}$ hasonlóságából:

$$
\frac{a}{c}=\frac{x}{b-x}, \quad \text { ahonnan } \quad x=\frac{a b}{a+c}
$$


Tehát ezen a helyen van a függvénynek minimuma, és ez az $\left[A^{\prime} C^{\prime}\right]$ hosszával egyezik meg, azaz

$$
f_{\min }=\sqrt{b^{2}+(a+c)^{2}} .
$$

Megjegyzés: A diákok jól boldogultak a feladat geometriai nyelvre való fordításával, csupán az előnyös modell megtalálása okozott némi fejtörést.

Voltak akik az $a$, ill. $c$ hosszúságú szakaszokat a $b$ hosszúságúnak ugyanazon oldalán vették fel, így nehezebben tudtak a minimumra következtetni. Megbeszéltük az ilyen esetben tipikus tükrözéses módszert is, amit, főleg az egyetemisták közül, többen ismertek.

Fölvetődött a koordináta-rendszer bevezetésének gondolata is, hiszen csak egy hajszálnyira álltunk tőle, így megvizsgáltuk úgy is a problémát, és ezzel át is léptünk a következő témakörbe.

\section{Házi feladatok}

4.1.9. Feladat. Igazold, hogy bármilyen $x_{i}, y_{i}, z_{i} \in \mathbb{R}_{+}, i \in\{1,2, \ldots, n\}$ számok esetén

$$
\sum_{i=1}^{n} \sqrt{x_{i}{ }^{2}+y_{i}{ }^{2}+z_{i}{ }^{2}} \geq \sqrt{\left(\sum_{i=1}^{n} x_{i}\right)^{2}+\left(\sum_{i=1}^{n} y_{i}\right)^{2}+\left(\sum_{i=1}^{n} z_{i}\right)^{2}}
$$

Megoldás. A 4.1.2. feladat térbeli változata.

Mérjük fel egymás után az $O x y z$ térbeli derékszögű koordináta-rendszer $O x$ tengelyére az $x_{1}, x_{2}, \ldots, x_{n}$ távolságokat, az $O y$-ra az $y_{1}, y_{2}, \ldots, y_{n}$ távolságokat, valamint az $O z$ tengelyre a $z_{1}, z_{2}, \ldots, z_{n}$ távolságokat, majd tekintsünk azt az $\left(x_{1}+x_{2}+\ldots+x_{n}\right) \times\left(y_{1}+\right.$ $\left.y_{2}+\ldots+y_{n}\right) \times\left(z_{1}+z_{2}+\ldots+z_{n}\right)$-es téglatestet, amelynek egyik csúcsa az origóban van, az $O x, O y, O z$ tengelyek pedig egy-egy oldalélének a tartóegyenesei.

Fektessünk az $X_{i} \in O x, i \in\{1,2, \ldots, n\}$ pontokon keresztül párhuzamos síkokat az $y O z$ síkkal, az $Y_{i} \in O y, i \in\{1,2, \ldots, n\}$ pontokon keresztül az $x O z$ síkkal, és a $Z_{i} \in O z$, $i \in\{1,2, \ldots, n\}$ pontokon keresztül az $x O y$ síkkal. Így egy téglatest-háló keletkezik.

$\mathrm{Az}$ igazolandó egyenlőtlenség bal oldalán megjelenő gyökkifejezések az $x_{i}, y_{i}, z_{i}$, $i \in\{1,2, \ldots, n\}$ hosszúságú szakaszok által meghatározott kis téglatestek testátlóinak hosszai, míg a jobb oldali kifejezés a nagy téglatest testátlójának hossza. Mivel a nagy téglatest testátlója nem hosszabb, mint a kis téglatestek testátlóinak összhossza, ezért az egyenlőtlenség igaz.

4.1.10. Feladat. Igazold, hogy $x y z+u v(1-x)+(1-y)(1-v) t+(1-z)(1-u)(1-t) \leq 1$, $\forall x, y, z, t, u, v \in[0,1]$ esetén.

Megoldás. A 4.1.4. feladat térbeli változata.

4.1.11. Feladat. Határozd meg az $x y+y z+z x$ kifejezés értékét, ha az $x, y, z$ pozitiv valós számok teljesítik a következő összefüggéseket!

$$
2 x^{2}+2 x y+y^{2}=288, \quad z^{2}+2 z x+2 x^{2}=338, \quad y^{2}+z^{2}=50 .
$$

Megoldás. A megoldás teljesen hasonló a 4.1.6. feladat megoldásához. 
4.1.12. Feladat. Határozd meg az $S=x y+y z$ kifejezés értékét, ha az $x, y, z$ pozitív valós számok teljesítik a következö összefüggéseket:

$$
x^{2}+y^{2}=16, \quad y^{2}+z^{2}=48, \quad y^{2}=x z .
$$

Megoldás. A 4.12. ábrán az $A B C$ háromszög magassága legyen $C D=y, A D=z$ és $D B=x$. Ekkor $A C=4 \sqrt{3}$ és $B C=4$.

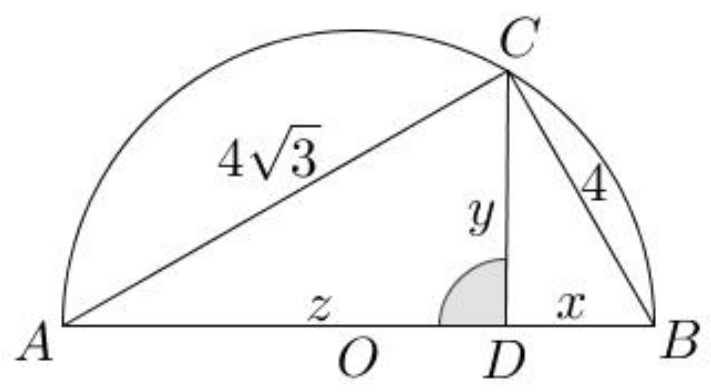

4.12. ábra. Területek

A keresett kifejezés értéke éppen

$$
S=x y+y z=2 T_{B C D}+2 T_{A C D}=2 T_{A B C}=16 \sqrt{3} .
$$

Söt, mivel $y=\frac{A C \cdot B C}{B A}=\frac{16 \sqrt{3}}{\sqrt{(4 \sqrt{3})^{2}+4^{2}}}=2 \sqrt{3}$, ezért $m(\widehat{C A D})=30^{\circ}$.

4.1.13. Feladat. Igazold, hogy $\sqrt{a^{2}-c^{2}}+\sqrt{b^{2}-c^{2}} \leq \frac{a b}{c}, \forall a, b, c>0$ esetén!

Megoldás. Legyen az $O A B$ háromszögben $O A=a, O B=b$ és az $O C$ magasság hossza pedig $c$.

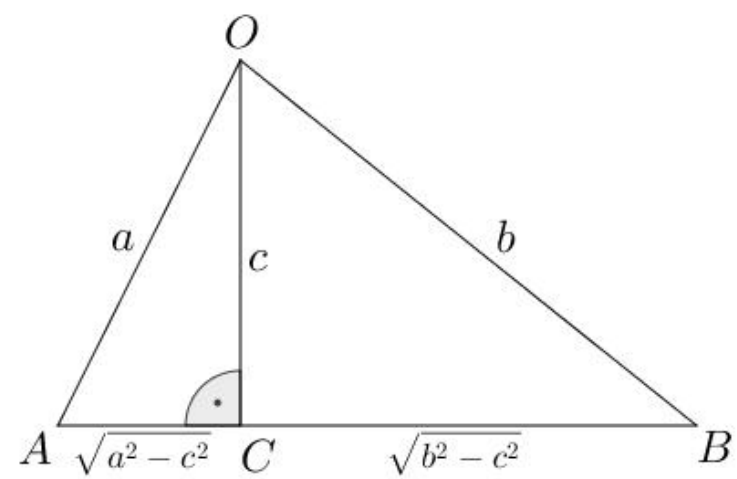

4.13. ábra. Területek

Ekkor, amint a 4.13. ábrán is látható, egyrészt

$$
T_{O A B}=\frac{a b \sin \widehat{A O B}}{2} \leq \frac{a b}{2},
$$


másrészt

$$
T_{O A B}=T_{O A C}+T_{O B C}=\frac{c \sqrt{a^{2}-c^{2}}}{2}+\frac{c \sqrt{b^{2}-c^{2}}}{2} .
$$

Így

$$
c \sqrt{a^{2}-c^{2}}+c \sqrt{b^{2}-c^{2}} \leq a b
$$

ahonnan

$$
\sqrt{a^{2}-c^{2}}+\sqrt{b^{2}-c^{2}} \leq \frac{a b}{c}, \quad \forall a, b, c>0 .
$$

4.1.14. Feladat. Oldd meg az alábbi egyenletet a $\left(0, \frac{\pi}{2}\right)$ intervallumon!

$$
\sqrt{2-2 \cos x}+\sqrt{10-6 \cos x}=\sqrt{10-6 \cos 2 x}
$$

1. megoldás. Ha az egyenlet mindkét oldalát négyzetre emeljük, a

$$
4 \cos x-3 \cos 2 x-1=\sqrt{2-2 \cos x} \sqrt{10-6 \cos x}
$$

egyenlethez jutunk. Ha ezt ismét négyzetre emeljük, felhasználjuk, hogy $\cos 2 x=2 \cos ^{2} x-$ 1 , rendezzük, majd az $u=\cos x$-et helyettesítjük, az

$$
9 u^{4}-12 u^{3}-5 u^{2}+12 u-4=0
$$

egyenlethez jutunk. Ennek a gyökei $u_{1,2}=\frac{2}{3}, u_{3}=1$ és $u_{4}=-1$. Az $x \in\left(0, \frac{\pi}{2}\right)$ feltétel alapján csak a $\cos x=\frac{2}{3}$ lehetséges, így $x=\arccos \frac{2}{3}$.

2. megoldás. Szerkesszük meg az $O A B$ és $O B C$ háromszögeket úgy, hogy $O A=$ $O B=1, O C=3$ és $m(\widehat{A O B})=m(\widehat{B O C})=x$. (4.14. ábra)

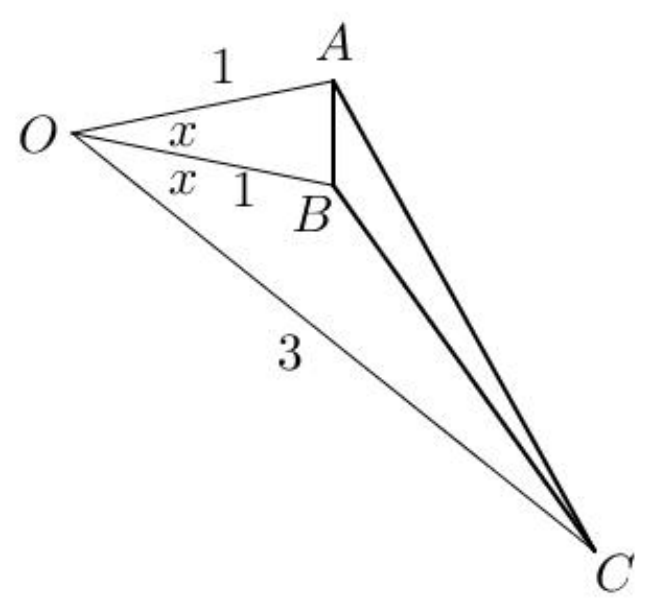

4.14. ábra.

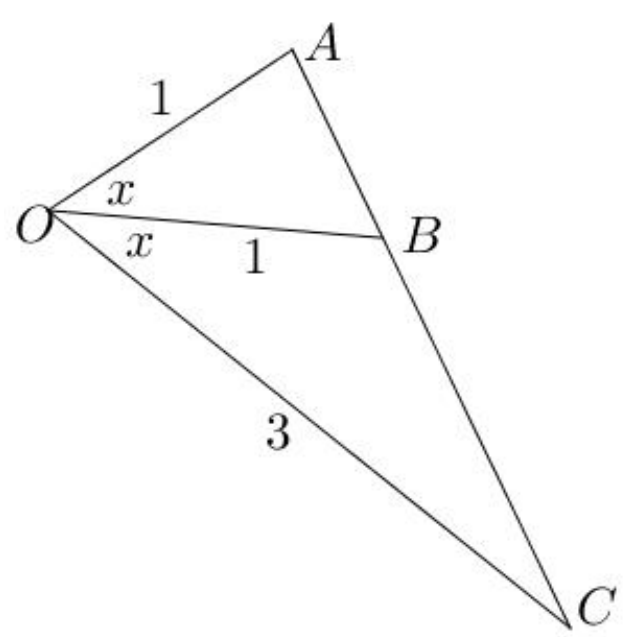

4.15. ábra.

A koszinusztétel alapján $A B=\sqrt{2-2 \cos x}, B C=\sqrt{10-6 \cos x}$ és $C A=$ $\sqrt{10-6 \cos 2 x}$, de az egyenlet alapján $A B+B C=A C$. Ez pontosan akkor teljesül, ha $B \in(A C)$ (4.15. ábra), így $O B$ szögfelező az $O A C$ háromszögben. A szögfelezőtétel alapján $\frac{A B}{B C}=\frac{1}{3}$. Ebből következik, hogy

$$
9(2-2 \cos x)=10-6 \cos x,
$$

ahonnan $\cos x=\frac{2}{3}$. A megoldás tehát $x=\arccos \frac{2}{3}$. 
4.1.15. Feladat. Igazold az alábbi egyelőtlenségeket!

a) $\sqrt{x^{2}+x y+y^{2}}+\sqrt{z^{2}+z x+x^{2}} \geq \sqrt{y^{2}+y z+z^{2}}, \forall x, y, z>0$

b) $\sqrt{x^{2}-x y+y^{2}}+\sqrt{z^{2}-z x+x^{2}} \geq \sqrt{y^{2}+y z+z^{2}}, \forall x, y, z>0$

Megoldás. Mindkét esetben a koszinusztétel van elbújtatva a gyökök alatt, így azok szakaszhosszakat jelentenek. A megfelelő modellt megszerkesztve, a háromszögegyenlőtlenség alapján azonnaliak az állítások.

4.1.16. Feladat. Igazold, hogy ha $x, y, z>0$ és $x y z(x+y+z)=1$, akkor

$$
(x+y)(y+z)+(y+z)(z+x)+(z+x)(x+y) \geq 6 .
$$

Rávezetö feladat. $A z A B C$ háromszögbe irt kör a $B C, A C$ és $A B$ oldalakat a $D$, $E$, illetve $F$ pontokban érinti. Számítsd ki az oldalakon meghatározott szakaszok hosszát az oldalak hosszának függvényében!

Megoldás. Az $A B C$ háromszögbe írt kör érintse a $B C, A C$ és $A B$ oldalakat a $D$, $E$, illetve $F$ pontokban, az oldalak pedig legyenek $c=x+y, a=y+z$, ill. $b=z+x$ hosszúságúak. (4.16. ábra)

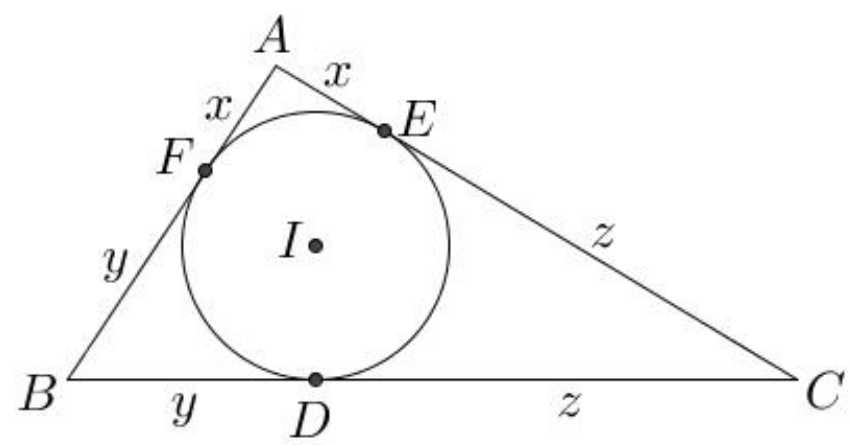

4.16. ábra. A háromszögbe írt kör

Ekkor $A F=A E=x=s-a, B F=B D=y=s-b, C D=C E=z=s-c$, a háromszög területe pedig

$$
T=T_{A B C}=\sqrt{s(s-a)(s-b)(s-c)}=\sqrt{x y z(x+y+z)}=1 .
$$

Másrészt viszont

$$
\begin{aligned}
& 2=2 T=A B \cdot A C \cdot \sin \widehat{B A C} \leq(x+y)(z+x), \\
& 2=2 T=B C \cdot B A \cdot \sin \widehat{A B C} \leq(y+z)(x+y), \\
& 2=2 T=C A \cdot C B \cdot \sin \widehat{B C A} \leq(z+x)(y+z),
\end{aligned}
$$

ahonnan

$$
(x+y)(y+z)+(y+z)(z+x)+(z+x)(x+y) \geq 6 .
$$




\subsubsection{Koordinátageometria}

Az előző részben tárgyaltakhoz hasonlóan, általában valamilyen geometriai objektum hosszára, területére vagy térfogatára vonatkozó összefüggésre utaló, a feladat szövegében szereplő kifejezés felfedezése a célravezető.

Néhány tipikus, a problémák szövegében gyakran előforduló „árulkodó jel”:

- $\sqrt{x^{2}+y^{2}}$ - pont távolsága az origótól

- $\sqrt{(a-b)^{2}+(c-d)^{2}}$ - két pont távolsága

- $a \cdot x+b \cdot y=c$ - egyenes egyenlete, általában feltételként

- $x^{2}+y^{2}=c$ - origó középpontú kör egyenlete

- $\sqrt{1-x^{2}}$ - origó középpontú, egység sugarú körön levő pont ordinátája, tehát távolsága az $O x$ tengelytől

- $x^{2}+y^{2}+z^{2}=c$ - origó középpontú gömb egyenlete

- $a \cdot x+b \cdot y+c \cdot z=d$ - sík egyenlete

\section{Órán megoldott feladatok}

4.1.17. Feladat. Határozd meg az $f: \mathbb{R} \rightarrow \mathbb{R}, f(x)=\sqrt{x^{2}-2 x+2}+\sqrt{x^{2}-6 x+10}$ függvény szélsöértékpontjait és szélsöértékeit!

\section{Kérdések:}

- Mire emlékeztetnek a leképezési törvényben szereplő kifejezések? Át tudnád alakítani megfelelő szerkezetűvé azokat?

- Hogyan lehetne megjeleníteni a gyököket? Miben lenne érdemes dolgozni?

- Mit jelentenek ekkor a függvényértékek?

- Meg tudnád jeleníteni a kapott modellen a minimumot, maximumot?

- Mikor, milyen $x$ esetén következik ez be? Mennyi az értéke?

- Tudnád általánosítani a feladatot? Esetleg hasonló modelleken alapuló feladatokat készíteni?

Megoldás: A függvény leképezési törvénye

$$
f(x)=\sqrt{(x-1)^{2}+1}+\sqrt{(x-3)^{2}+1}
$$

alakra hozható. Mivel a gyökök két pont távolságát leíró összefüggésre emlékeztetnek, tekintsük a derékszögü koordináta-rendszerben az $A(1 ; 1), B(3 ; 1)$ rögzített, valamint a $P(x ; 0)$ futópontot. Ekkor

$$
f(x)=A P_{x}+P_{x} B .
$$


A 4.17. ábráról leolvasható, hogy a függvénynek nincs maximuma, hiszen felülről nem korlátos, mert ha minden határon felül növeljük vagy csökkentjük $x$ értékét, a $P_{x}$ tetszőlegesen eltávolítható az $A$ és $B$ pontoktól, tehát az $A P_{x}+P_{x} B$ összhossz tetszőlegesen nagy lehet.

Minimum viszont van, éppen amikor a töröttvonal összhossza minimális. Ezt szemléletesen úgy jeleníthetjük meg, hogy „kiterítjük” a két szakaszt, azaz tükrözzük például a $B$ pontot az $O x$ tengelyre, a tükörkép legyen $B^{\prime}(3 ;-1)$.

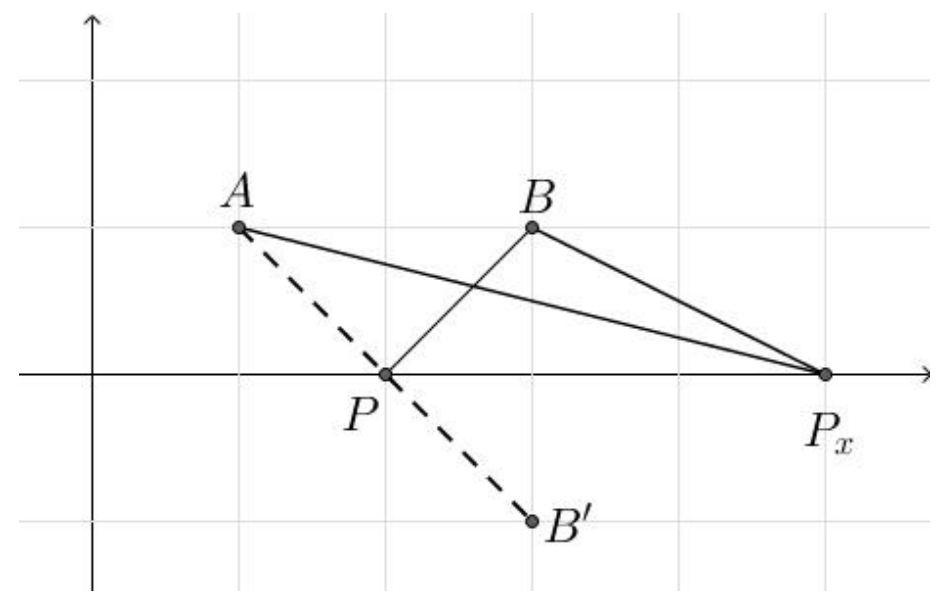

4.17. ábra. A függvényértékek geometriai jelentése

Ekkor

$$
f_{\text {min }}(x)=\min \left(A P_{x}+P_{x} B\right)=\min \left(A P_{x}+P_{x} B^{\prime}\right)=A B^{\prime}=2 \sqrt{2},
$$

tehát a függvény minimuma $2 \sqrt{2}$, és ezt az értékét a függvény akkor veszi fel, amikor $A B^{\prime} \cap O x=\{P\}$, tehát a minimumhely $x=2$.

Általánosabb esetek: Teljesen ezen a modellen alapul az

$$
f: \mathbb{R} \rightarrow \mathbb{R}, \quad f(x)=\sqrt{(x-a)^{2}+(y-b)^{2}}+\sqrt{(x-c)^{2}+(y-d)^{2}}
$$

függvény szélsőértékeinek meghatározása!

Némileg más modellek alapján, de teljesen hasonló eljárással határozhatók meg a 4.1.28. házi feladatban szereplő függvények szélsőértékei.

Megjegyzés: Mivel az előző rész utolsó feladata kapcsán már tulajdonképpen megbeszéltük a problémát, a diákoknak nem okozott nehézséget a geometriai modell elkészítése és a szélsőértékek megállapítása. A 4.1.28. házi feladatban szereplő függvényekhez hasonlóakat sikerült gyártaniuk, majd egymással megoldatniuk.

4.1.18. Feladat. Bizonyítsd be, hogy bármilyen $a, b$ és c vagy mind pozitív, vagy mind negatív valós számra teljesül, hogy

$$
\sqrt{(a-b)^{2}+b^{2}}+\sqrt{(c-b)^{2}+b^{2}} \geq \sqrt{a^{2}+c^{2}},
$$

és egyenlöség pontosan akkor áll fenn, ha

$$
\frac{1}{|b|}=\frac{1}{|a|}+\frac{1}{|c|} .
$$




\section{Kérdések:}

- Mire emlékeztetnek a gyökkifejezések?

- Hol és hogyan lehetne megjeleníteni azokat? Milyen rögzített pontok felvétele szükséges?

- Mit jelent a geometriai modell alapján az egyenlőtlenség? Mikor áll fenn egyenlőség?

Megoldás: Ha $a, b, c>0$, akkor a derékszögü koordináta-rendszer első negyedében tekintsük az $A(a, 0), B(b, b)$ és $C(0, c)$ pontokat. (4.18. ábra)

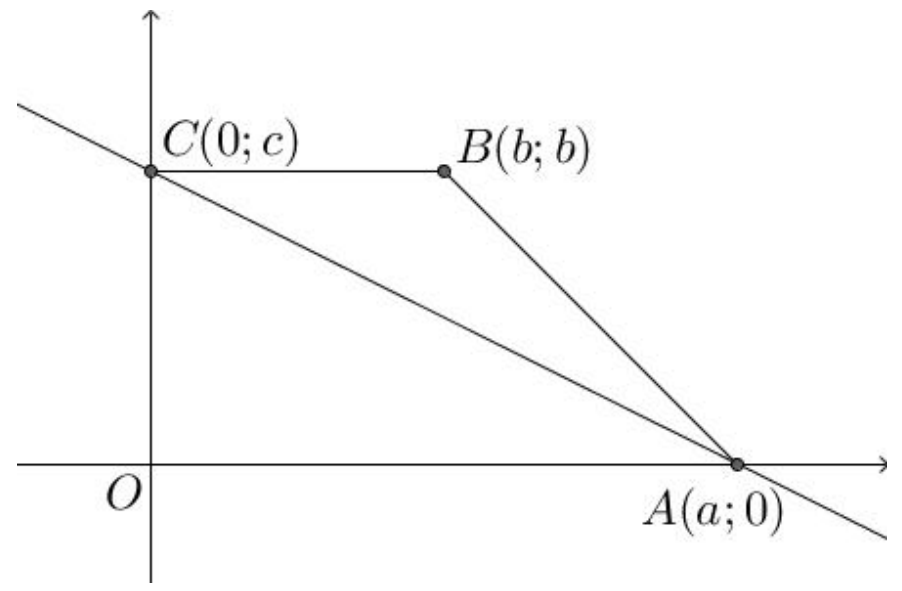

4.18. ábra. Az egyenlőtlenség geometriai modellje

Ekkor a háromszög-egyenlőtlenség alapján $A B+B C \geq A C$, azaz

$$
\sqrt{(a-b)^{2}+b^{2}}+\sqrt{(c-b)^{2}+b^{2}} \geq \sqrt{a^{2}+c^{2}},
$$

és egyenlöség akkor áll fenn, ha a $B$ pont rajta van az $A C$ egyenesen. Az $A C$ egyenes egyenletének tengelymetszetes alakja

$$
\frac{x}{a}+\frac{y}{c}=1
$$

és mivel $B \in A C$, ezért

$$
\frac{b}{a}+\frac{b}{c}=1 \Longleftrightarrow \frac{1}{a}+\frac{1}{c}=\frac{1}{b} .
$$

Ha viszont $a, b, c<0$, vagyis a pontok a harmadik negyedben helyezkednek el, akkor

$$
\frac{1}{-a}+\frac{1}{-c}=\frac{1}{-b} \text {. }
$$

Összességében tehát egyenlőség akkor teljesül, ha

$$
\frac{1}{|b|}=\frac{1}{|a|}+\frac{1}{|c|} \text {. }
$$

Megjegyzés: A diákok önállóan jól boldogultak. Sikerült megválasztaniuk a megfelelő pontokat és elkészíteniük a helyes modellt. Az egyenlőség geometriai megállapításával, és annak algebrai levezetésével sem volt különösebb problémájuk, viszont nem mindenki tért ki a két eset tárgyalására, egyesek csupán az $a, b, c>0$ esettel foglalkoztak. 
4.1.19. Feladat. Bizonyítsd be, hogy ha $a, b \in \mathbb{R}_{+}$, és $4 a+3 b=12$, akkor
a) $-4 \leq a-b \leq a+b \leq 4$
b) $-16 \leq a^{2}-b^{2} \leq 9$
c) $5,76 \leq a^{2}+b^{2} \leq 16$
d) $\sqrt{a^{2}+b^{2}-6 a+9}+\sqrt{a^{2}+b^{2}-8 b+16}=5$
e) $-5 \leq \sqrt{a^{2}+b^{2}-6 a+9}-\sqrt{a^{2}+b^{2}-8 b+16} \leq 5$
f) $0 \leq \sqrt{a^{2}+b^{2}-6 a+9} \cdot \sqrt{a^{2}+b^{2}-8 b+16} \leq 6,25$

\section{Kérdések:}

- Mire emlékeztet a feltétel? Hogyan jeleníthető meg geometriailag?

- Át tudnád alakítani úgy a feltételt, hogy mindkét változó egy harmadik közös paraméter segítségével legyen kifejezve?

- Mire emlékeztetnek a gyökkifejezések? Hogyan jeleníthetők meg?

- Hogyan becsülhető meg két pozitív szám szorzata, ha ismert azok összege?

Megoldás: Ábrázoljuk a $4 a+3 b=12$ egyenletü egyenest a derékszögü koordinátarendszerben, a tengelymetszetek $A(3 ; 0)$ és $B(0 ; 4)$. (4.19. ábra)

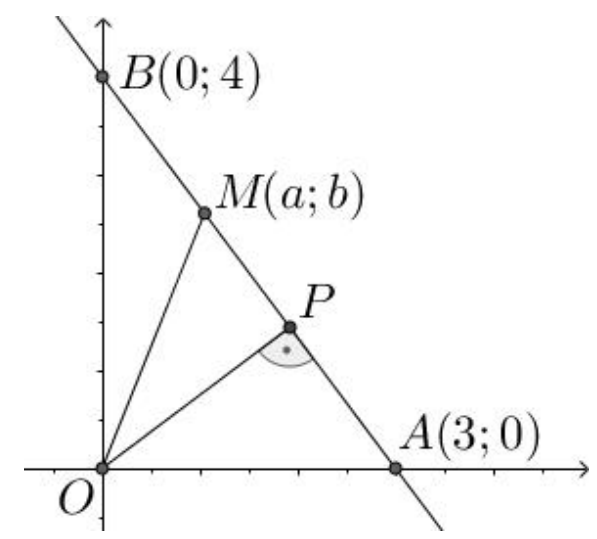

4.19. ábra. Az egyenlőtlenségek geometriai modelljei

Ekkor a $0 \leq k \leq 1$ valós számra az $[A B]$ paraméteres egyenlete:

$$
\left\{\begin{array}{l}
a=3 k \\
b=4-4 k
\end{array}\right.
$$

a) Innen $a-b=-4+7 k \geq-4$, és $a+b=4-k \leq 4$, tehát

$$
-4 \leq a-b \leq a+b \leq 4
$$


b) Ugyanakkor $a^{2}-b^{2}=-7 k^{2}+32 k-16$, és mivel ennek a maximumhelye jobbra esik a $[0 ; 1]$ intervallumtól, ezért a kifejezés szigorúan növekvő a [0;1]-on, így $-16 \leq a^{2}-b^{2} \leq 9$.

c) Legyen $M \in[A B]$ futópont. Ekkor $O M=\sqrt{a^{2}+b^{2}}$, és mivel

$$
d(O, A B) \leq O M \leq O B
$$

ezért

$$
\frac{3 \cdot 4}{5} \leq \sqrt{a^{2}+b^{2}} \leq 4 \quad \Longleftrightarrow \quad 5,76=2,4^{2} \leq a^{2}+b^{2} \leq 16
$$

d)

$$
M A+M B=A B \quad \Longleftrightarrow \quad \sqrt{(a-3)^{2}+b^{2}}+\sqrt{a^{2}+(b-4)^{2}}=5
$$

e) Mivel $M \in[A B]$, ezért $|M A-M B| \leq 5$, vagyis

$$
-5 \leq \sqrt{a^{2}+b^{2}-6 a+9}-\sqrt{a^{2}+b^{2}-8 b+16} \leq 5
$$

f) Végül a számtani és mértani közepek közötti összefüggés alapján

$$
0 \leq M A \cdot M B \leq\left(\frac{M A+M B}{2}\right)^{2}=\left(\frac{A B}{2}\right)^{2}=\left(\frac{5}{2}\right)^{2},
$$

ahonnan

$$
0 \leq \sqrt{a^{2}+b^{2}-6 a+9} \cdot \sqrt{a^{2}+b^{2}-8 b+16} \leq 6,25
$$

Megjegyzés: A diákok hamar felismerték, hogy a feltétel egy egyenes egyenlete, amit célszerü ábrázolni a koordináta-rendszerben, viszont az $[A B]$ paraméteres alakba való átírásának szükségessége már nem volt egyértelmü. Miután a sugallatomra ez megtörtént, a további alpontok megoldása nem okozott gondot. Az utolsó alpont bizonyult még kissé nehéznek, de a segítő kérdés után a többség azt is meg tudta oldani.

4.1.20. Feladat. Határozd meg az alábbi kifejezés minimumát! $\sqrt{x^{2}+y^{2}-2 x-2 y+2}+\sqrt{x^{2}+y^{2}+2 x-2 y+2}+\sqrt{x^{2}+y^{2}-2 x+2 y+2}+3 \sqrt{x^{2}+y^{2}}$

\section{Kérdések:}

- Mire emlékeztetnek a gyök alatti kifejezések? Át tudnád alakítani azokat?

- Meg tudnád jeleníteni a gyököket valamilyen geometriai modellen?

- Milyen rögzített pontokat kellene ábrázolni?

- Hogyan jelenik meg a kapott ábrán az összeg?

- Meg tudnád jeleníteni az összeg minimumát? Milyen értékekre veszi fel ezt a kifejezés?

- Tudnál hasonló modellen alapuló feladatot szerkeszteni? 
Megoldás: A gyökök alatt teljes négyzeteket alakítva ki a megadott kifejezés

$$
\sqrt{(x-1)^{2}+(y-1)^{2}}+\sqrt{(x+1)^{2}+(y-1)^{2}}+\sqrt{(x-1)^{2}+(y+1)^{2}}+3 \sqrt{x^{2}+y^{2}}
$$

alakra hozható.

Tekintsük a derékszögü koordináta-rendszerben az $A(1 ; 1), B(-1 ; 1), C(1 ;-1)$, valamint az $M(x ; y)$ pontokat. (4.20. ábra) Ekkor a megadott kifejezés éppen az

$$
M A+M B+M C+3 M O
$$

töröttvonal hosszát adja meg, és a feladat ennek az össztávolságnak a minimumát kéri.

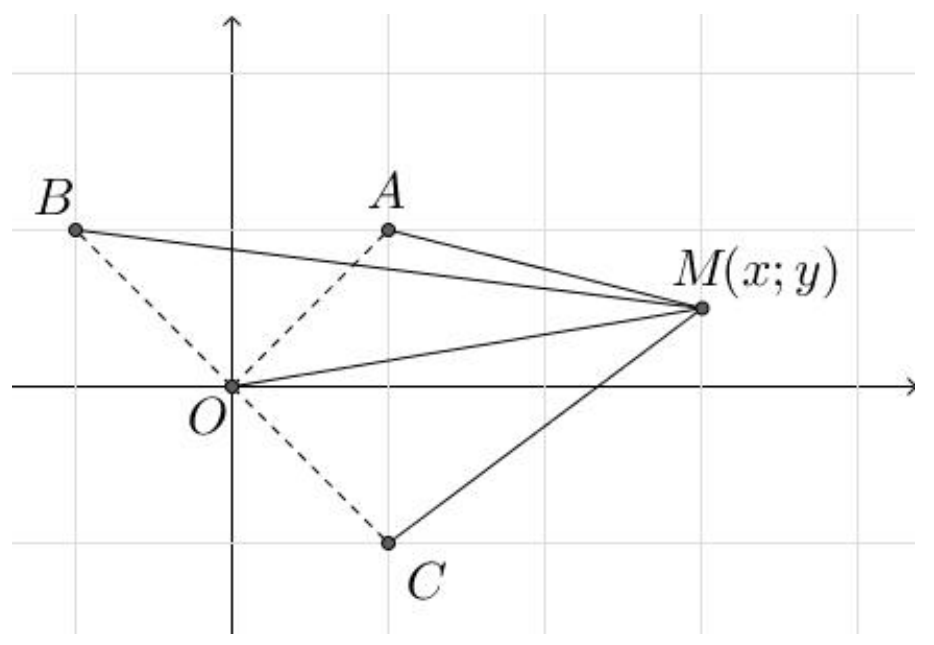

4.20. ábra. A minimális összhossz

A 4.20. ábráról leolvasható, hogy

$$
\left\{\begin{array}{l}
M A+M O \geq O A=\sqrt{2} \\
M B+M O \geq O B=\sqrt{2} \\
M C+M O \geq O C=\sqrt{2}
\end{array}\right.
$$

Tehát az összeg minimuma $3 \sqrt{2}$, és ezt akkor éri el, amikor a fenti egyenlötlenségekben egyidőben egyenlőség áll fenn, vagyis amikor $M=O$, azaz $x=y=0$.

Megjegyzés: A diákok hamar átalakították a gyök alatti kifejezéseket, és szinte kivétel nélkül sikerült ábrázolniuk a gyökkifejezések összegét. A geometriai modell alapján a minimumot is viszonylag egyszerüen megsejtették, viszont a bizonyításhoz szükséges egyenlőtlenségek felírása csak erős sugallat alapján ment.

Néhányan hasonló feladatot is szerkesztettek. Például az egyik diák javaslata:

Határozd meg az alábbi kifejezés minimumát!

$$
\begin{aligned}
& E(x, y)=\sqrt{x^{2}+y^{2}+2 x+1}+\sqrt{x^{2}+y^{2}+6 x+9}+ \\
& +\sqrt{x^{2}+y^{2}+2 x-4 y+5}+3 \sqrt{x^{2}+y^{2}+4 x-2 y+5}
\end{aligned}
$$

A minimum szintén $3 \sqrt{2}$, melyet a kifejezés $x=-2$ és $y=1$ esetén vesz fel. 
4.1.21. Feladat. Bizonyitsd be, hogy ha az $a, b, c, d \in \mathbb{R}$ számok esetén $4 a+3 b=12$ és $3 d-4 c=12$, akkor

$$
\sqrt{a^{2}+b^{2}}+\sqrt{c^{2}+d^{2}}+\sqrt{(a-c)^{2}+(b-d)^{2}} \geq 7,68 .
$$

\section{Kérdések:}

- Mire emlékeztetnek a feltételek? Hát a gyök alatti kifejezések?

- Meg tudnád-e jeleníteni a feltételeket valamilyen geometriai modellen?

- Hogyan ábrázolhatók ekkor a gyökök? Miként jelenik meg a kapott ábrán az összegük?

- Hogyan ábrázolható a minimális összeg?

- Mikor van éppen egyenlőség az egyenlőtlenségben?

- Adott háromszögbe írt háromszögek közül melyiknek minimális a kerülete? Hogyan tudnád bizonyítani?

Megoldás: A feltételben két egyenes egyenlete szerepel. A $\sqrt{a^{2}+b^{2}}$ geometriailag az origónak és az $A(a, b)$ pontnak a távolságát jelenti. Hasonlóan $\sqrt{c^{2}+d^{2}}$ az origónak és a $B(c, d)$ pontnak a távolsága, és a bizonyítandó egyenlőtlenség bal oldalán a harmadik kifejezés pontosan az $A B$ szakasz hossza.

Ha tekintjük az $O$ középpontú derékszögü koordináta-rendszert, a feladat feltételei azt jelentik, hogy az $A(a, b)$ pont a $d_{1}: 4 x+3 y=12$ és a $B(c, d)$ pont a $d_{2}:-4 x+3 y=12$ egyenesen mozog. (4.21. ábra) Ezekkel a feltételekkel a bizonyítandó egyenlőtlenség

$$
O A+O B+A B \geq 7,68
$$

alakba írható, és bizonyítani kell, hogy az $O A B$ háromszög kerülete nem kisebb 7,68-nál.

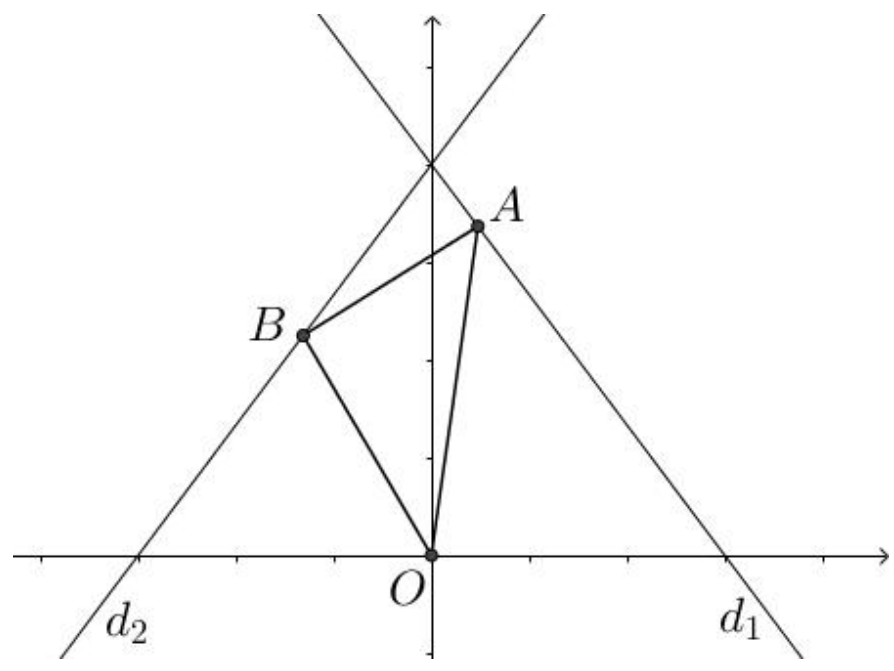

4.21. ábra. A minimális kerületű beírt háromszög 
Feladatunk hasonlít a Fagnano-feladatra, amelyben egy háromszögbe írható háromszögek közül a legkisebb kerületüt kell meghatározni. Ezért az $O A B$ háromszög oldalait terítsük ki úgy, hogy a kerület két rögzített pont közti távolságot fejezzen ki. Vegyük fel $O$-nak a $d_{1}$-re vonatkozó $O_{1}$, és a $d_{2}$-re vonatkozó $O_{2}$ szimmetrikusát. (4.22. ábra) Így $O A=O_{1} A$ és $O B=O_{2} B$, tehát

$$
O A+O B+A B=O_{1} A+O_{2} B+A B
$$

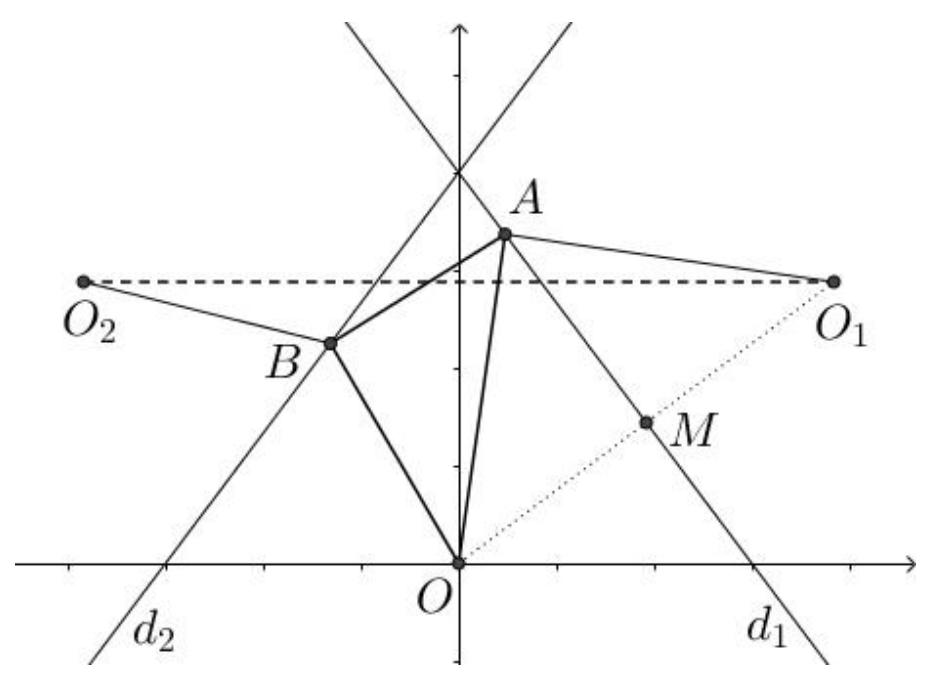

4.22. ábra. Fagnano feladata

Másrészt $O_{1} A+O_{2} B+A B \geq O_{1} O_{2}$, tehát $O A+O B+A B \geq O_{1} O_{2}$. Ha az $\left[O_{1} O_{2}\right]$ hossza 7,68, akkor a bizonyítás teljes, ha annál nagyobb, akkor a feladatbeli egyenlőtlenség élesíthető, míg ha annál kisebb, akkor a feladatbeli egyenlőtlenség nem igaz. Tehát a feladat megoldása érdekében elégséges kiszámítani az $\left[O_{1} O_{2}\right]$ hosszát.

Észrevehető, hogy ha $O_{1}$ koordinátái $x_{1}$ és $y_{1}$, akkor az $O_{2}$ koordinátái $-x_{1}$ és $y_{1}$, mert szimmetrikusak az $O y$ tengelyre nézve, így $O_{1} O_{2}=2 x_{1}$. Tehát elég meghatározni $x_{1}$-et.

Az $O O_{1}$ egyenlete $y=m x$ alakú, és az $O O_{1} \perp d_{1}$ feltételből adódik, hogy $m=\frac{3}{4}$. Ha $O O_{1} \cap d_{1}=\{M\}$, melynek koordinátái $x_{2}$ és $y_{2}$, akkor $x_{1}=2 x_{2}$ és $y_{1}=2 y_{2}$, mert $M$ az $\left[O O_{1}\right]$ felezőpontja. Az $M$ koordinátáira igaz tehát, hogy

$$
\left\{\begin{array}{l}
3 x_{2}+4 y_{2}=12 \\
y_{2}=\frac{3}{4} x_{2}
\end{array}\right.
$$

Innen $x_{2}=\frac{48}{25}$, és így $O_{1} O_{2}=4 x_{2}=\frac{192}{25}=7,68$. Tehát az egyenlőtlenség igaz, hiszen

$$
\sqrt{a^{2}+b^{2}}+\sqrt{c^{2}+d^{2}}+\sqrt{(a-c)^{2}+(b-d)^{2}}=O A+O B+A B \geq O_{1} O_{2}=7,68 .
$$

Egyenlöség akkor áll fenn, amikor az $A$ és $B$ pontok a $d_{1}$ és $d_{2}$ egyenesek $O_{1} O_{2}$ által elmetszett pontjai. Ekkor $a=0,84, b=2,88, c=-0,84$ és $d=2,88$. Az így kialakuló $O A B$ háromszög éppen a két egyenes és az $O x$ tengely által alkotott nagy háromszög talpponti háromszöge.

Megjegyzés: A feltételek és a gyökök geometriai megjelenítése némi segítséggel viszonylag egyszerüen ment, ám a háromszög oldalainak „kiterítése” a minimum érdekében, 
csak 1-2 diáknak jutott eszébe. Az ötlet közkincsé tétele után, a számításokkal már egyszerúbb vagy bonyolultabb módon ugyan, de elboldogultak, a minimumot és a minimumhelyeket is sikerült meghatározniuk.

Mivel a diákok közül senki sem ismerte a Fagnano-feladatot, ezért Fejér Lipótnak a tükrözéses, kerület-kiterítéses módszerével bizonyítottuk, hogy adott háromszögbe írt háromszögek közül a talpponti háromszög a minimális kerületű.

4.1.22. Feladat. Igazold, hogy ha $a, b, c, d>0, a^{2}+b^{2}=1$ és $4 c+3 d=12$, akkor

$$
1,96 \leq(a-c)^{2}+(b-d)^{2} \leq 17
$$

\section{Kérdések:}

- Mire emlékeztetnek a feltételben szereplő összefüggések?

- Hogyan tudnád megjeleníteni azokat?

- Hogyan ábrázolható ekkor a bizonyítandó egyenlőtlenségben szereplő kifejezés?

- Mikor minimális és mikor maximális ez a távolság?

Megoldás: Mivel az egyenlőtlenség belső része két pont távolságát megadó összefüggésre hasonlít, ábrázoljuk a derékszögű koordináta-rendszerben az origó középpontú, egység sugarú, $a^{2}+b^{2}=1$ egyenletü kört, valamint a $4 c+3 d=12$, vagy $\frac{c}{3}+\frac{d}{4}=1$ egyenletü egyenest. (4.23. ábra)

A feladat egy a körön, illetve egy az egyenesen mozgó pont távolságnégyzetének szélsőértékeit kéri. Ezért legyenek $M(a ; b) \in \mathcal{C}(O ; 1)$ és $N(c ; d) \in A B$ futópontok, valamint $A(3 ; 0), B(0 ; 4), E(1 ; 0)$ és $C \in A B$ úgy, hogy $O C \perp A B$, ill. $\{D\}=O C \cap \mathcal{C}(O ; 1)$ rögzített pontok a derékszögü koordináta-rendszer első negyedében.

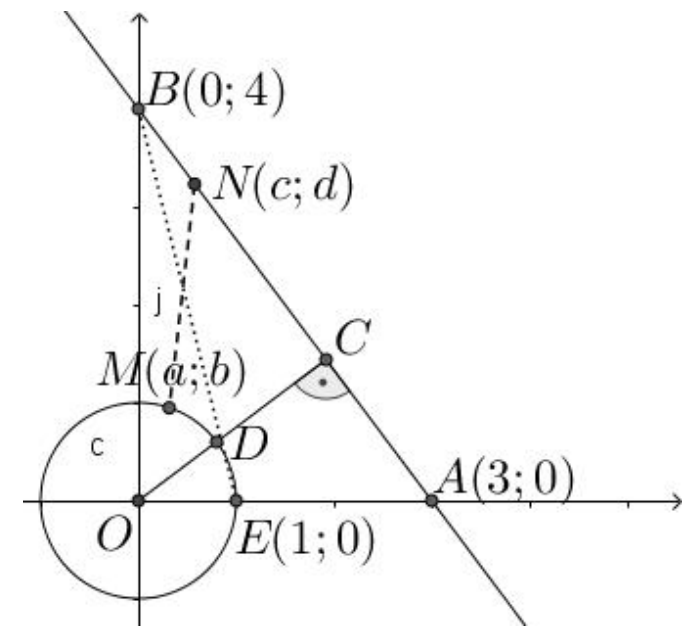

4.23. ábra. A két pont távolságnégyzetének szélsőértékei

Mivel $M \in \mathcal{C}(O ; 1)$ és $N \in A B$, ezért

$$
C D^{2} \leq M N^{2} \leq E B^{2}
$$


De

$$
C D=O C-O D=\frac{O A \cdot O B}{A B}-O D=\frac{12}{5}-1=\frac{7}{5}
$$

valamint

$$
E B=\sqrt{O E^{2}+O B^{2}}=\sqrt{17}=1,4
$$

Tehát

$$
1,96 \leq(a-c)^{2}+(b-d)^{2} \leq 17 .
$$

Ugyanakkor $(a-c)^{2}+(b-d)^{2}$ akkor minimális, azaz éppen 1,96 , amikor $M=D$ és $N=C$, vagyis $a=0,8, b=0,6, c=1,92$ és $d=1,44$; a maximumát, vagyis a 17 -et pedig $a=1, b=0, c=0$ és $d=4$ esetén veszi fel.

Megjegyzés: A feladat lehetőséget adott kísérletezésre, így a feltételek ábrázolása után, a megfelelően mozgó szakasz minimális hosszának meghatározása érdekesnek bizonyult a diákok számára, és jól is boldogultak fele. A számítások sem voltak annyira összetettek, hogy gondot okoztak volna.

4.1.23. Feladat. Igazold, hogy $\forall x, y \in \mathbb{R},|x| \leq 1,|y| \leq 1$ esetén

$$
\sqrt{1-x^{2}}+\sqrt{1-y^{2}} \leq \sqrt{4-(x+y)^{2}} .
$$

\section{Kérdések:}

- Mire emlékeztetnek a feltételben szereplő egyenlőtlenségek?

- Hát a bizonyítandó egyenlőtlenségben megjelenő gyökkifejezések? Hogyan hozható a jobb oldali is olyan alakra, mint a bal oldalon levők?

- Milyen geometriai modell bevezetése lenne célszerű? Hogyan jeleníthetők meg ezen a gyökök?

- Az ábra alapján hogyan becsülhető a két gyök összege, esetleg azok számtani középarányosa?

Megoldás. Geometriailag megközelítve a feladatot az egyenlőtlenségben szereplő három gyökkifejezés egy-egy szakasz hossza lehet. Ugyanakkor mivel

$$
\sqrt{4-(x+y)^{2}}=2 \cdot \sqrt{1-\left(\frac{x+y}{2}\right)^{2}}
$$

ezért igazolnunk kell, hogy

$$
\sqrt{1-x^{2}}+\sqrt{1-y^{2}} \leq 2 \sqrt{1-\left(\frac{x+y}{2}\right)^{2}}
$$

vagy

$$
\frac{\sqrt{1-x^{2}}+\sqrt{1-y^{2}}}{2} \leq \sqrt{1-\left(\frac{x+y}{2}\right)^{2}}, \quad \forall x, y \in \mathbb{R},|x| \leq 1,|y| \leq 1
$$


Úgy a feltételbeli $|x| \leq 1,|y| \leq 1$ megkötések, mint a gyökök $\sqrt{1-a^{2}}$ alakja, origó középpontú, egység sugarú körmodellen való próbálkozást sugall.

Ezért legyen $M$ és $N$ az $x^{2}+y^{2}=1$ egyenletü, origó középpontú, egység sugarú kör felső félkörének két tetszőleges pontja (4.24. ábra). Továbbá legyen $M^{\prime}$ és $N^{\prime}$ az $M$, illetve $N$ vetülete az $O x$ tengelyre, és hasonlóan $P^{\prime}$ az $M N$ szakasz $P$ felezőpontjának a vetülete az $O x$ tengelyre.

Ha $M^{\prime}(x, 0)$ és $N^{\prime}(y, 0)$, akkor $P^{\prime}\left(\frac{x+y}{2}, 0\right)$ és

$$
M M^{\prime}=\sqrt{r^{2}-O M^{\prime 2}}=\sqrt{1-x^{2}}, \quad N N^{\prime}=\sqrt{1-y^{2}} .
$$

Ugyanakkor

$$
P P^{\prime}=\sqrt{O P^{2}-\left(\frac{x+y}{2}\right)^{2}} \leq \sqrt{1-\left(\frac{x+y}{2}\right)^{2}} .
$$

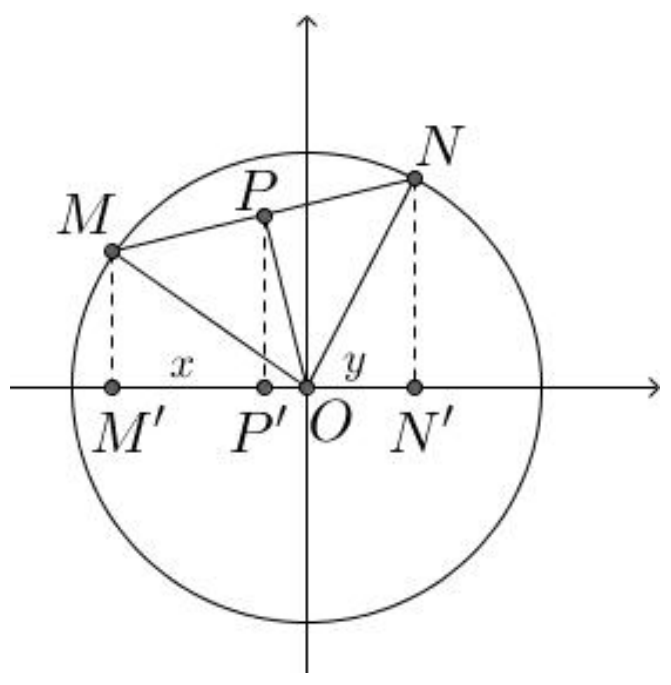

4.24. ábra. Az feladat geometriai modellje

De $P P^{\prime}$ az $M M^{\prime} N^{\prime} N$ trapéz középvonala, így $P P^{\prime}=\frac{M M^{\prime}+N N^{\prime}}{2}$, amit felhasználva éppen a bizonyítandó egyenlőtlenséghez jutunk, hiszen

$$
\frac{\sqrt{1-x^{2}}+\sqrt{1-y^{2}}}{2} \leq \sqrt{1-\left(\frac{x+y}{2}\right)^{2}}=\frac{1}{2} \sqrt{4-(x+y)^{2}},
$$

ahonnan

$$
\sqrt{1-x^{2}}+\sqrt{1-y^{2}} \leq \sqrt{4-(x+y)^{2}} .
$$

Megjegyzés: A probléma elég nagy fejtörést okozott a diákoknak, hiszen sem a megfelelő modell, sem az azon való célszerü okoskodás nem bizonyult egyszerü feladatnak. Elég direkt rávezetés útján végül ugyan rájöttek a körmodell bevezetésére, de a gyököknek megfelelő hosszúságú szakaszok felvétele újabb jelentős akadályt jelentett. A már teljes modell alapján a középvonal megbecslése sem volt azonnali. Tapasztalataim és elmondásaik szerint is, a körön való operálás gondot jelenet a többség számára. 


\section{Vektorok}

Algebrai szövegezésü probléma esetén, ha a kijelentésben szereplő kifejezések előállíthatók valamilyen koordinátájú vektorokkal végzett műveletek, illetve azokra vonatkozó tulajdonságok leírásaként, érdemes segítségül hívni azokat. Gyakori például valamilyen vektor abszolút értékének, két vektor skaláris szorzatának, vagy éppen ezekre felírt megfelelő nevezetes egyenlőtlenségnek az alkalmazása.

A foglalkozásokon két vektor skaláris szorzatának kétféle módon való felírása, a háromszög- illetve sokszög-egyenlőtlenség, valamint a Cauchy-Bunyakovszkij-Schwarz-, és a Minkowski-egyenlőtlenségek fordultak elő.

4.1.24. Feladat. Igazold, hogy $\forall x, y \in \mathbb{R},|x| \leq 1,|y| \leq 1$ esetén

$$
\sqrt{1-x^{2}}+\sqrt{1-y^{2}} \leq \sqrt{4-(x+y)^{2}} .
$$

\section{Kérdések:}

- Hogyan becsülhető felülről két vektor skaláris szorzata?

- Hogyan tudnád a bal oldalt két vektor lineáris kombinációjaként előállítani? Milyen értékek legyenek a két vektor koordinátái?

- Belátható-e a becslés alapján a kért egyenlőtlenség?

- Tudnád általánosítani a kijelentést?

Megoldás: Az előző rész utolsó feladatát megoldjuk vektoriális módszerrel is. Felhasználjuk a Cauchy-Bunyakovszkij-Schwarz-egyenlőtlenség vektoriális változatát:

$$
\left|\overrightarrow{v_{1}} \cdot \overrightarrow{v_{2}}\right| \leq\left|\overrightarrow{v_{1}}\right| \cdot\left|\overrightarrow{v_{2}}\right|
$$

Legyenek

$$
\overrightarrow{v_{1}}=(1 ; 1), \quad \overrightarrow{v_{2}}=\left(\sqrt{1-x^{2}} ; \sqrt{1-y^{2}}\right) .
$$

Az egyenlőtlenség alapján

$$
\begin{gathered}
1 \cdot \sqrt{1-x^{2}}+1 \cdot \sqrt{1-y^{2}} \leq \sqrt{1^{2}+1^{2}} \cdot \sqrt{\left(\sqrt{1-x^{2}}\right)^{2}+\left(\sqrt{1-y^{2}}\right)^{2}}, \\
\sqrt{1-x^{2}}+\sqrt{1-y^{2}} \leq \sqrt{2\left(2-x^{2}-y^{2}\right)} \leq \sqrt{4-(x+y)^{2}},
\end{gathered}
$$

ami igaz, hiszen utóbbit négyzetre emelve, majd rendezve, az $(x-y)^{2} \geq 0$ azonossághoz jutunk. Tehát valóban

$$
\sqrt{1-x^{2}}+\sqrt{1-y^{2}} \leq \sqrt{4-(x+y)^{2}} .
$$

A megoldásból kiderül, hogy a nevezetes vektoriális egyenlőtlenség alkalmazásával a kértnél szigorúbb egyenlőtlenséget sikerült bizonyítani. Ha azonban a

$$
\overrightarrow{v_{1}}=(\sqrt{1-x} ; \sqrt{1-y}), \quad \overrightarrow{v_{2}}=(\sqrt{1+x} ; \sqrt{1+y})
$$


vektorokat választjuk, akkor éppen a kért egyenlőtlenséghez jutunk.

Általánosítás: $\forall x_{i} \in \mathbb{R},\left|x_{i}\right| \leq 1, i=\overline{1, n}$ esetén

$$
\sum_{i=1}^{n} \sqrt{1-x_{i}^{2}} \leq \sqrt{n^{2}-\left(\sum_{i=1}^{n}\right)^{2}} .
$$

Megjegyzés: A feladatot szinte teljes egészében lépésről-lépésre együtt oldottuk, mert a diákoknak nem volt sem korábbi hasonló tapasztalatuk, sem teljesen önálló ötletük.

4.1.25. Feladat. Oldd meg a $3 x \sqrt{9-4 x^{2}}+2 x \sqrt{4-9 x^{2}}=6$ egyenletet!

\section{Kérdések:}

- Hogyan hozható kapcsolatba az egyenlet bal oldala a vektorokkal?

- Milyen értékek legyenek a vektorok koordinátái?

- Hogyan számítható ki két vektor skaláris szorzata? Mindkét felírást figyelembe vetted?

- Mire lehet következtetni a kapott eredmények alapján?

- A skaláris szorzat becslésével hogyan tudnád igazolni ugyanezt?

1. megoldás: A gyökkifejezések miatt az egyenlet a $D=\left(0, \frac{2}{3}\right]$ intervallumon értelmezett.

Tekintsük a $\overrightarrow{v_{1}}=\left(3 x, \sqrt{4-9 x^{2}}\right)$ és $\overrightarrow{v_{2}}=\left(\sqrt{9-4 x^{2}}, 2 x\right)$ vektorokat. Felhasználjuk két vektor skaláris szorzatának értelmezését, miszerint

$$
\overrightarrow{v_{1}} \cdot \overrightarrow{v_{2}}=\left|\overrightarrow{v_{1}}\right| \cdot\left|\overrightarrow{v_{2}}\right| \cdot \cos \alpha,
$$

ahol $\alpha$ a két vektor által bezárt szög. Ugyanakkor

$$
\begin{gathered}
\overrightarrow{v_{1}} \cdot \overrightarrow{v_{2}}=3 x \sqrt{9-4 x^{2}}+2 x \sqrt{4-9 x^{2}}=6, \\
\left|\overrightarrow{v_{1}}\right|=\sqrt{9 x^{2}+4-9 x^{2}}=2, \quad\left|\overrightarrow{v_{2}}\right|=\sqrt{9-4 x^{2}+4 x^{2}}=3,
\end{gathered}
$$

tehát

$$
\overrightarrow{v_{1}} \cdot \overrightarrow{v_{2}}=2 \cdot 3 \cos \alpha=6 \cos \alpha .
$$

A skaláris szorzatra kapott két értékből következik, hogy $\cos \alpha=1$, ahonnan $\alpha=0$, vagyis a két vektor párhuzamos. Ez pontosan akkor teljesül, amikor

$$
\frac{3 x}{\sqrt{9-4 x^{2}}}=\frac{\sqrt{4-9 x^{2}}}{2 x}, \quad x \neq \frac{2}{3} .
$$

Ezt keresztbe szorozva, négyzetre emelve, majd rendezve, a $97 x^{2}=36$ egyenlethez jutunk, amelynek két megoldása közül csak az $x=\frac{6}{\sqrt{97}}$ megoldása az eredeti egyenletnek. 
2. megoldás: $D=\left(0, \frac{2}{3}\right]$, és alkalmazzuk a Cauchy-Bunyakovszkij-Schwarzegyenlötlenséget a $\overrightarrow{v_{1}}=\left(3 x, \sqrt{4-9 x^{2}}\right)$ és $\overrightarrow{v_{2}}=\left(\sqrt{9-4 x^{2}}, 2 x\right)$ vektorokra. Ekkor

$$
3 x \cdot \sqrt{9-4 x^{2}}+2 x \cdot \sqrt{4-9 x^{2}} \leq \sqrt{9 x^{2}+4-9 x^{2}} \cdot \sqrt{9-4 x^{2}+4 x^{2}}=2 \cdot 3=6,
$$

és egyenlöség pontosan akkor áll fenn, ha

$$
\frac{3 x}{\sqrt{9-4 x^{2}}}=\frac{\sqrt{4-9 x^{2}}}{2 x}, \quad x \neq \frac{2}{3},
$$

ahonnan $x=\frac{6}{\sqrt{97}}$ az egyetlen olyan megoldás, amelyik kielégíti az eredeti egyenletet is.

Megjegyzés: Az előző feladat megoldását ismerve, a diákok már önállóbban boldogultak evvel a feladattal. Akik teljesen magukra előre dolgoztak, azok a 2. megoldást adták meg elöször, és csak a kérdéseim hatására gondolkodtak el más módszeren is.

4.1.26. Feladat. Igazold, hogy bármely $a, b, c, d \geq 0$ esetén teljesül, hogy

$$
\sqrt{a+b+c+d}+\sqrt{b+c+d}+\sqrt{c+d}+\sqrt{d} \geq \sqrt{a+4 b+9 c+16 d}
$$

\section{Kérdések:}

- Hogyan hozhatók kapcsolatba a gyökök a vektorokkal?

- A sokszög-egyenlőtlenségre gondolva, mit jelentenek geometriailag a gyökök?

- Hány vektor megválasztására van szükség?

- Mik legyenek a koordináták, hogy a megfelelő gyököket kapjuk normaként?

- Tudnád általánosítani a feladat kijelentését?

Megoldás: A $\overrightarrow{v_{1}}=(\sqrt{a}, \sqrt{b}, \sqrt{c}, \sqrt{d}), \overrightarrow{v_{2}}=(0, \sqrt{b}, \sqrt{c}, \sqrt{d}), \overrightarrow{v_{3}}=(0,0, \sqrt{c}, \sqrt{d})$ és $\overrightarrow{v_{4}}=(0,0,0, \sqrt{d})$ négydimenziós vektorokra alkalmazzuk a

$$
\left\|\overrightarrow{v_{1}}\right\|+\left\|\overrightarrow{v_{2}}\right\|+\left\|\overrightarrow{v_{3}}\right\|+\left\|\overrightarrow{v_{4}}\right\| \geq\left\|\overrightarrow{v_{1}}+\overrightarrow{v_{2}}+\overrightarrow{v_{3}}+\overrightarrow{v_{4}}\right\|
$$

ötszög-egyenlötlenséget (a háromszög-egyenlötlenség kiterjesztett változata):

$$
\begin{gathered}
\sqrt{(\sqrt{a})^{2}+(\sqrt{b})^{2}+(\sqrt{c})^{2}+(\sqrt{d})^{2}}+\sqrt{(\sqrt{b})^{2}+(\sqrt{c})^{2}+(\sqrt{d})^{2}}+ \\
+\sqrt{(\sqrt{c})^{2}+(\sqrt{d})^{2}}+\sqrt{(\sqrt{d})^{2}} \geq \sqrt{(\sqrt{a})^{2}+(2 \sqrt{b})^{2}+(3 \sqrt{c})^{2}+(4 \sqrt{d})^{2}}
\end{gathered}
$$

ami éppen a kijelentésbeli

$$
\sqrt{a+b+c+d}+\sqrt{b+c+d}+\sqrt{c+d}+\sqrt{d} \geq \sqrt{a+4 b+9 c+16 d}
$$

egyenlőtlenség. 
Általánositás: A feladat általánosítható $n$ valós szám esetére. A fenti módszerrel a sokszög-egyenlőtlenséget jól megválasztott $n$-dimenziós vektorokra alkalmazva kapjuk, hogy $\forall a_{i} \in \mathbb{R}, i \in\{1,2, \ldots, n\}$ esetén

$$
\begin{gathered}
\sqrt{a_{1}^{2}+a_{2}^{2}+\ldots+a_{n}^{2}}+\sqrt{a_{2}^{2}+\ldots+a_{n}^{2}}+\ldots+\sqrt{a_{n-1}^{2}+a_{n}^{2}}+\sqrt{a_{n}^{2}} \geq \\
\geq \sqrt{a_{1}^{2}+2^{2} \cdot a_{2}^{2}+\ldots+(n-1)^{2} \cdot a_{n-1}^{2}+n^{2} \cdot a_{n}^{2}}
\end{gathered}
$$

Ha $a_{1}=a_{2}=\ldots=a_{n}=a \neq 0$, akkor az

$$
1+\sqrt{2}+\sqrt{3}+\ldots+\sqrt{n}>\sqrt{1^{2}+2^{2}+3^{3}+\ldots+n^{2}}
$$

szigorú egyenlőtlenséghez jutunk, ami az előzőtől függetlenül, matematikai indukcióval is igazolható.

Megjegyzés: A feladat az egyetemi hallgatók többségének nehézséget okozott. Csak azok a hallgatók tudták önállóan jól megválasztani a vektorokat, akiknek már volt előzőleg tapasztalatuk hasonló feladatok megoldásában. A középiskolásokkal csak a többdimenziós vektor normájának megemlítése után, futólag foglalkoztunk evvel a feladattal.

4.1.27. Feladat. Határozd meg az $f$ valós szám maximális értékét, ha az $a, b, c, d, e, f$ valós számok összege 10, és

$$
(a-1)^{2}+(b-1)^{2}+(c-1)^{2}+(d-1)^{2}+(e-1)^{2}+(f-1)^{2}=6 .
$$

\section{Kérdések:}

- Felhasználva a számok összegére vonatkozó információt, hogyan alakítható át a feltételbeli egyenlőség?

- Miként tudnál felírni egy csak f-re vonatkozó egyenlőtlenséget?

- Ismerve a számok összegét és négyzetösszegét, milyen nevezetes egyenlőtlenség segítene?

- Hogy hozható ez kapcsolatba a vektorokkal? Hány vektor megválasztására van szükség? Mik legyenek azok koordinátái?

- Mikor veszi fel $f$ a maximumát?

Megoldás: A négyzeteket felbontva és felhasználva, hogy a számok összege 10 kapjuk, hogy

$$
a^{2}+b^{2}+c^{2}+d^{2}+e^{2}+f^{2}=2(a+b+c+d+e+f)=20 .
$$

Alkalmazzuk a Cauchy-Bunyakovszkij-Schwarz-egyenlőtlenséget az $\vec{x}=(1,1,1,1,1)$ és $\vec{y}=(a, b, c, d, e)$ vektorokra. Ez alapján

$$
(1 \cdot a+1 \cdot b+1 \cdot c+1 \cdot d+1 \cdot e)^{2} \leq\left(1^{2}+1^{2}+1^{2}+1^{2}+1^{2}\right)\left(a^{2}+b^{2}+c^{2}+d^{2}+e^{2}\right),
$$

azaz

$$
a+b+c+d+e \leq 5\left(a^{2}+b^{2}+c^{2}+d^{2}+e^{2}\right)
$$


De $a+b+c+d+e=10-f$, és $a^{2}+b^{2}+c^{2}+d^{2}+e^{2}=20-f^{2}$ miatt

$$
(10-f)^{2} \leq 5\left(20-f^{2}\right)^{2} \Longleftrightarrow 6 f^{2}-20 f \leq 0,
$$

ahonnan $0 \leq f \leq \frac{10}{3}$, tehát $f$ maximális értéke $\frac{10}{3}$. Ezt akkor veszi fel, amikor az egyenlőtlenségben egyenlőség van, vagyis amikor a két vektor párhuzamos. Ez $a=b=$ $c=d=e$ esetén áll fenn, sőt ekkor $5 a+\frac{10}{3}=10$ miatt, $a=b=c=d=e=\frac{4}{3}$.

Megjegyzés: Mivel a feladat önálló munkára meglehetősen nehéznek bizonyult, ezért a kérdéseimre adott válaszokat követve együtt oldottuk meg azt.

\section{Házi feladatok}

4.1.28. Feladat. Határozd meg az alábbi függvények szélsőértékpontjait és szélsőértékeit!

a) $f: \mathbb{R} \rightarrow \mathbb{R}, f(x)=\sqrt{x^{2}-8 x+41}+\sqrt{x^{2}-2 x+37}$

b) $g: \mathbb{R} \rightarrow \mathbb{R}, g(x)=\sqrt{2 x^{2}-2 x+13}+\sqrt{2 x^{2}-10 x+17}$

c) $h: \mathbb{R} \rightarrow \mathbb{R}, h(x)=\sqrt{2 x^{2}+2 x+13}+\sqrt{2 x^{2}-24 x+80}$

Megoldás. A megoldások teljesen hasonlóak a 4.1.17. feladat megoldásához.

4.1.29. Feladat. Bizonyitsd be, hogy bármilyen $a, b, c, d \in \mathbb{R}$ esetén

a) $\sqrt{a^{2}+b^{2}}+\sqrt{a^{2}+c^{2}} \geq|b-c|$,

b) $\sqrt{a^{2}+b^{2}}+\sqrt{c^{2}+d^{2}} \geq \sqrt{(a-c)^{2}+(b-d)^{2}}$.

Megoldás. A 4.25. és 4.26. ábrákon látható modellek alapján könnyen igazolhatók.

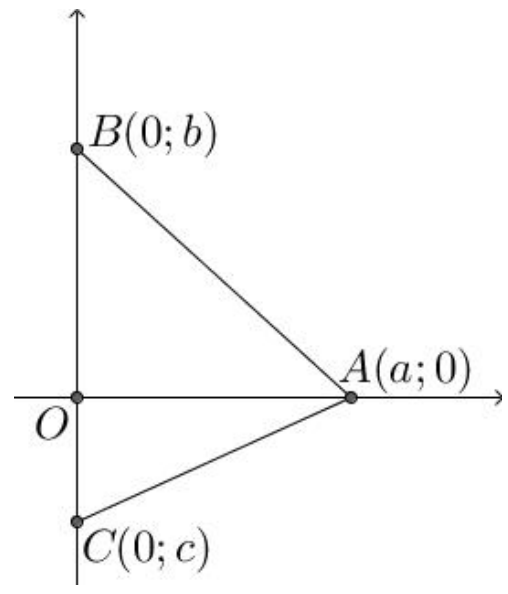

4.25. ábra.

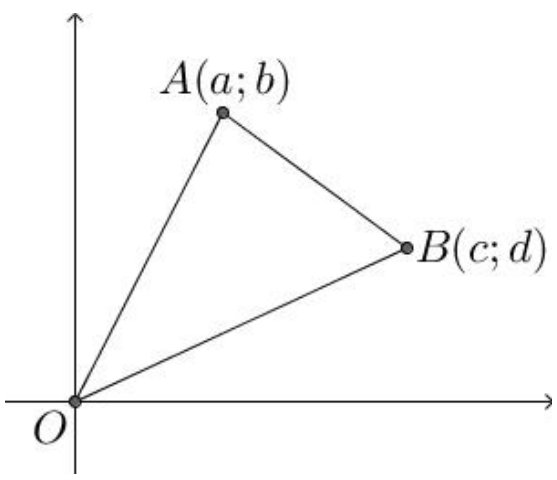

4.26. ábra.

4.1.30. Feladat. Oldd meg az alábbi egyenletrendszert, ha $x, z, t>0$ és $y<0$.

$$
\left\{\begin{array}{l}
x^{2}+z^{2}=y^{2}+t^{2}=2 \\
\sqrt{(x-1)^{2}+(z+1)^{2}}+\sqrt{(x-y)^{2}+(z-t)^{2}}+\sqrt{(y+1)^{2}+(t+1)^{2}}=6
\end{array}\right.
$$


Megoldás. Mivel az első összefüggés egy-egy origó középpontú, $\sqrt{2}$ sugarú kör egyenlete, ezért legyen $A(x ; z)$ és $B(y ; t)$ két futópont a $\mathcal{C}(O ; \sqrt{2})$ körön úgy, hogy $A$ az első negyedben, míg $B$ a második negyedben helyezkedik el. Ugyanakkor legyen $C(-1 ;-1)$ és $D(1 ;-1)$ két rögzített pont ugyanezen a körön (4.27. ábra). Ekkor $C D=2$ rögzített, és

$$
A D=\sqrt{(x-1)^{2}+(z+1)^{2}}, B C=\sqrt{(y+1)^{2}+(t+1)^{2}}, A B=\sqrt{(x-y)^{2}+(z-t)^{2}} .
$$

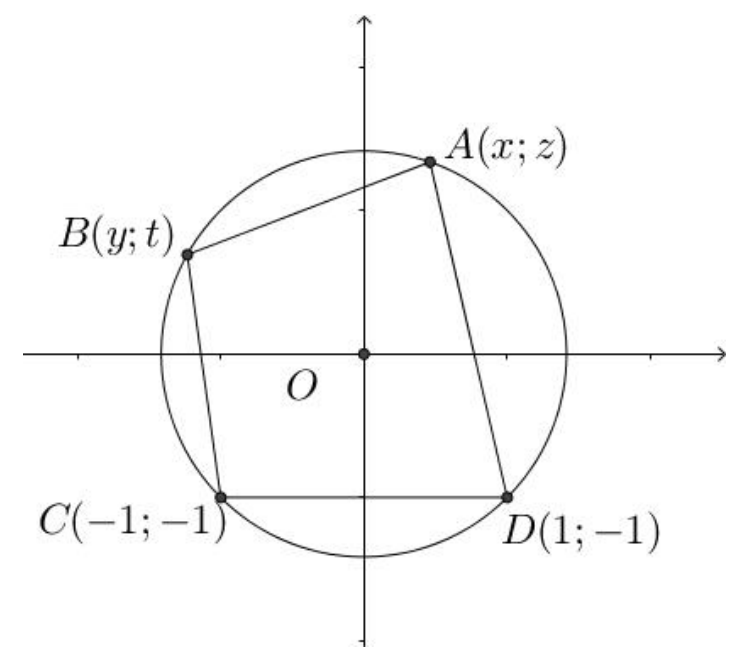

4.27. ábra. A rendszer geometriai modellje

A körbe írható maximális kerületű négyszög a 2 egység oldalhosszúságú négyzet, így

$$
A B+B C+C D+D A \leq 8 \quad \Longleftrightarrow A B+B C+D A \leq 6,
$$

de a a feladat kijelentésében szereplő második összefüggés szerint $A B+B C+D A=6$, ami csak $A B \| C D$ esetén teljesül. Ekkor viszont $x=z=t=1$ és $y=-1$, vagyis $M=\{(1,-1,1,1)\}$.

4.1.31. Feladat. Bizonyitsd be, hogy ha $a, b, c \in \mathbb{R}$, akkor

$$
\sqrt{(a+b)^{2}+c^{2}}+\sqrt{(a-b)^{2}+c^{2}} \geq 2|a| .
$$

Megoldás. A derékszögü koordináta-rendszerben tekintsük az $A(b, c), B(a, 0)$ és $C(-a, 0)$ pontokat. (4.28. ábra)

Mivel egy háromszög súlyvonalának hossza nem nagyobb a két szomszédos oldal hosszának számtani közepénél, ezért

$$
A B+A C \geq 2 \cdot A O \Longleftrightarrow \sqrt{(a+b)^{2}+c^{2}}+\sqrt{(a-b)^{2}+c^{2}} \geq 2|a| .
$$

Egyenlőség $b=c=0, a \in \mathbb{R}$ esetén, vagyis amikor $A B C$ elfajult háromszög, áll fenn.

4.1.32. Feladat. Igazold, hogy ha $a, b, c>0$, akkor

$$
\left(a^{3}+b^{3}+c^{3}\right)\left(\frac{1}{a}+\frac{1}{b}+\frac{1}{c}\right) \geq(a+b+c)^{2}
$$




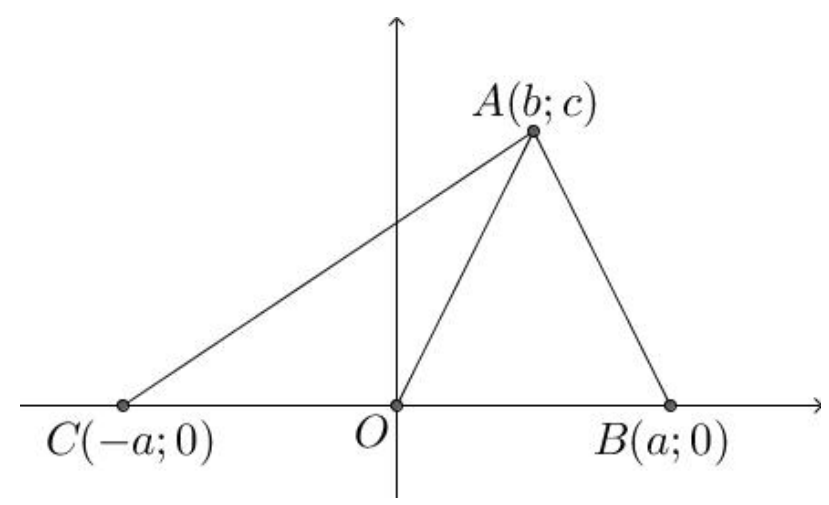

4.28. ábra. Az egyenlőtlenség geometriai modellje

Megoldás. A $\overrightarrow{v_{1}}=(a \sqrt{a}, b \sqrt{b}, c \sqrt{c})$ és $\overrightarrow{v_{2}}=\left(\frac{1}{\sqrt{a}}, \frac{1}{\sqrt{b}}, \frac{1}{\sqrt{c}}\right)$ vektorokra alkalmazzuk a $\left|\overrightarrow{v_{1}} \cdot \overrightarrow{v_{2}}\right| \leq\left\|\overrightarrow{v_{1}}\right\| \cdot\left\|\overrightarrow{v_{2}}\right\|$ Cauchy-Bunyakovszkij-Schwarz-egyenlőtlenséget. Mivel

$$
\left\|\overrightarrow{v_{1}}\right\|=\sqrt{a^{3}+b^{3}+c^{3}}, \quad\left\|\overrightarrow{v_{2}}\right\|=\sqrt{\frac{1}{a}+\frac{1}{b}+\frac{1}{c}}, \quad\left|\overrightarrow{v_{1}} \cdot \overrightarrow{v_{2}}\right|=a+b+c,
$$

a Cauchy-Bunyakovszkij-Schwarz-egyenlötlenség alapján

$$
a+b+c \leq \sqrt{a^{3}+b^{3}+c^{3}} \cdot \sqrt{\frac{1}{a}+\frac{1}{b}+\frac{1}{c}},
$$

amit négyzetre emelve éppen a kijelentésbeli egyenlőtlenséghez jutunk.

Egyenlőség akkor áll fenn, ha a két vektor párhuzamos, vagyis ha

$$
\frac{a \sqrt{a}}{\frac{1}{\sqrt{a}}}=\frac{a \sqrt{b}}{\frac{1}{\sqrt{b}}}=\frac{a \sqrt{c}}{\frac{1}{\sqrt{c}}} \quad \Longleftrightarrow \quad a^{2}=b^{2}=c^{2} .
$$

4.1.33. Feladat. Igazold, hogy bármely $a_{i}, b_{i} \in \mathbb{R}, i \in\{1,2, \ldots, n\}$ esetén

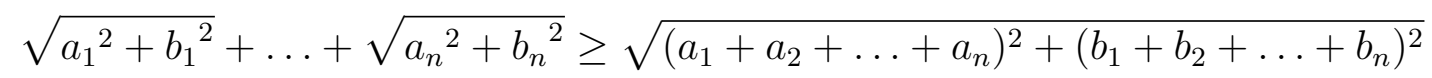

Megoldás. A $\overrightarrow{v_{1}}=\left(a_{1}, b_{1}\right), \overrightarrow{v_{2}}=\left(a_{2}, b_{2}\right), \ldots, \overrightarrow{v_{n}}=\left(a_{n}, b_{n}\right)$ kétdimenziós vektorokra alkalmazva a

$$
\left|\overrightarrow{v_{1}}\right|+\left|\overrightarrow{v_{2}}\right|+\ldots+\left|\overrightarrow{v_{n}}\right| \geq\left|\overrightarrow{v_{1}}+\overrightarrow{v_{2}}+\ldots+\overrightarrow{v_{n}}\right|
$$

sokszög-egyenlőtlenséget éppen a kijelentésbeli

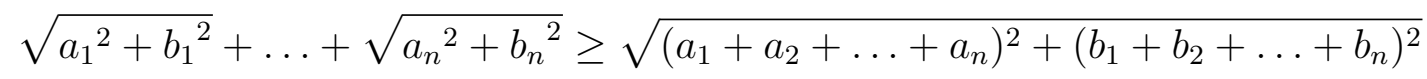

egyenlőtlenséget kapjuk.

Megjegyzés. Az egyenlőtlenség elemi geometriai bizonyítása a 4.1.2. feladat.

4.1.34. Feladat. Határozd meg az $x y+\sqrt{\left(1-x^{2}\right)\left(1-y^{2}\right)},|x| \leq 1$ és $|y| \leq 1$ kifejezés maximális értékét! 
Megoldás. A $\overrightarrow{v_{1}}=\left(x, \sqrt{1-x^{2}}\right)$ és $\overrightarrow{v_{2}}=\left(y, \sqrt{1-y^{2}}\right)$ vektorokra alkalmazzuk a Cauchy-Bunyakovszkij-Schwarz-egyenlőtlenséget: $\left|\overrightarrow{v_{1}} \cdot \overrightarrow{v_{2}}\right| \leq\left|\overrightarrow{v_{1}}\right| \cdot\left|\overrightarrow{v_{2}}\right|$. Ekkor

$$
\left|x y+\sqrt{\left(1-x^{2}\right)\left(1-y^{2}\right)}\right| \leq \sqrt{x^{2}+1-x^{2}} \cdot \sqrt{y^{2}+1-y^{2}}=1,
$$

ahonnan

$$
-1 \leq x y+\sqrt{\left(1-x^{2}\right)\left(1-y^{2}\right)} \leq 1 .
$$

A kifejezés maximuma 1 , melyet $x=y$ esetén vesz fel.

4.1.35. Feladat. Oldd meg az $\left\{\begin{array}{l}x^{2}+y^{2}+z^{2}=14 \\ x+2 y+3 z=14\end{array}\right.$ egyenletrendszert!

1. megoldás. A $\overrightarrow{v_{1}}=(1,2,3)$ és $\overrightarrow{v_{2}}=(x, y, z)$ vektorokra alkalmazzuk a CauchyBunyakovszkij-Schwarz-egyenlőtlenséget: $\left|\overrightarrow{v_{1}} \cdot \overrightarrow{v_{2}}\right| \leq\left\|\overrightarrow{v_{1}}\right\| \cdot\left\|\overrightarrow{v_{2}}\right\|$, azaz

$$
x+2 y+3 z \leq \sqrt{1+2+3} \cdot \sqrt{x^{2}+y^{2}+z^{2}}=\sqrt{14} \cdot 14=14 .
$$

Mivel az egyenlet alapján egyenlőség áll fenn, ezért teljesülnie kell, hogy

$$
\frac{x}{1}=\frac{y}{2}=\frac{z}{3}
$$

A második egyenletbe visszahelyettesítve kapjuk, hogy $x=1, y=2, z=3$.

2. megoldás. Az első összefüggés egy origó középpontú, $R=\sqrt{14}$ sugarú gömb egyenlete, a második pedig egy $\alpha$ síké, melyek vagy nem metszik egymást, vagy egy pontban érintik egymást, vagy egy kör a metszetük. Mivel

$$
d(O, \alpha)=\frac{|1 \cdot 0+2 \cdot 0+3 \cdot 0-14|}{\sqrt{1^{2}+1^{2}+1^{2}}}=\frac{14}{\sqrt{14}}=\sqrt{14}=R,
$$

ezért a sík érinti a gömböt, így a rendszernek csak egy megoldása van: az érintési pont koordinátái. Ez kiszámítható vagy kitalálható, így $M=\{(1,2,3)\}$.

3. megoldás. Az első egyenlet bal oldalára alkalmazzuk a számtani és négyzetes közepek közötti összefüggést:

$$
x+4 \cdot \frac{y}{2}+9 \cdot \frac{z}{3} \leq 14 \cdot \sqrt{\frac{x^{2}+4 \cdot \frac{y^{2}}{4}+9 \cdot \frac{z^{2}}{9}}{14}}=14,
$$

ahol egyenlőség csak akkor áll fenn, ha

$$
x=\frac{y}{2}=\frac{z}{3} .
$$

A második egyenletbe visszahelyettesítve kapjuk, hogy $x=1, y=2, z=3$.

4. megoldás. Teljes négyzetek kialakítása érdekében kivonjuk az első egyenletből a második kétszeresét:

$$
x^{2}-2 x+y^{2}-4 y+z^{2}-6 z=-14 .
$$

Ezt átrendezve kapjuk, hogy

$$
x^{2}-2 x+1+y^{2}-4 y+4+z^{2}-6 z+9=0,
$$

azaz

$$
(x-1)^{2}+(y-2)^{2}+(z-3)^{2}=0,
$$

ami csak akkor teljesülhet, ha $x=1, y=2, z=3$, és ezek megoldások is. 
4.1.36. Feladat. Oldd meg $a \sqrt{a^{x}+b^{x}}+\sqrt{b^{x}+c^{x}}+\sqrt{c^{x}+a^{x}}=\sqrt{2 a^{x}}+\sqrt{2 b^{x}}+\sqrt{2 c^{x}}$, $a, b, c>0$ egyenletet!

1. megoldás: Alkalmazzuk a Cauchy-Bunyakovszkij-Schwarz-egyenlőtlenséget a

$$
\overrightarrow{v_{1}}=(1,1,1) \quad \text { és a } \quad \overrightarrow{v_{2}}=\left(\sqrt{a^{x}+b^{x}}, \sqrt{b^{x}+c^{x}}, \sqrt{c^{x}+a^{x}}\right)
$$

vektorokra. Ekkor

$$
1 \cdot \sqrt{a^{x}+b^{x}}+1 \cdot \sqrt{b^{x}+c^{x}}+1 \cdot \sqrt{c^{x}+a^{x}} \leq \sqrt{(1+1+1)\left(a^{x}+b^{x}+b^{x}+c^{x}+c^{x}+a^{x}\right)},
$$

azaz

$$
\sqrt{a^{x}+b^{x}}+\sqrt{b^{x}+c^{x}}+\sqrt{c^{x}+a^{x}} \leq \sqrt{2} \sqrt{3\left(a^{x}+b^{x}+c^{x}\right)} .
$$

A bal oldalt lecserélve a feladat kijelentése alapján, majd leosztva $\sqrt{2}$-vel, kapjuk, hogy

$$
\sqrt{a^{x}}+\sqrt{b^{x}}+\sqrt{c^{x}} \leq \sqrt{3\left(a^{x}+b^{x}+c^{x}\right)} .
$$

Ezt négyzetre emelve, és leosztva 2-vel következik, hogy

$$
a^{x}+b^{x}+c^{x} \geq \sqrt{a^{x} \cdot b^{x}}+\sqrt{b^{x} \cdot c^{x}}+\sqrt{c^{x} \cdot a^{x}},
$$

ami átírható

$$
\left(\sqrt{a^{x}}\right)^{2}+\left(\sqrt{b^{x}}\right)^{2}+\left(\sqrt{c^{x}}\right)^{2} \geq \sqrt{a^{x}} \cdot \sqrt{b^{x}}+\sqrt{b^{x}} \cdot \sqrt{c^{x}}+\sqrt{c^{x}} \cdot \sqrt{a^{x}}
$$

alakba. Ez mindig igaz, és egyenlöség akkor áll fenn, ha $a^{x}=b^{x}=c^{x}$.

Ha $a=b=c$, akkor minden $x \in \mathbb{R}$ megoldás, ha pedig $a \neq b$, vagy $b \neq c$, vagy $c \neq a$, akkor csak $x=0$ megoldás.

2. megoldás. A számtani és négyzetes közepek közötti egyenlőtlenséget alkalmazzuk a bal oldali tagokra. Ekkor

$$
\sqrt{a^{x}+b^{x}}+\sqrt{b^{x}+c^{x}}+\sqrt{c^{x}+a^{x}} \leq 3 \cdot \sqrt{\frac{a^{x}+b^{x}+b^{x}+c^{x}+c^{x}+a^{x}}{3}}=\sqrt{2} \sqrt{3\left(a^{x}+b^{x}+c^{x}\right)},
$$

azaz

$$
\sqrt{a^{x}+b^{x}}+\sqrt{b^{x}+c^{x}}+\sqrt{c^{x}+a^{x}} \leq \sqrt{2} \sqrt{3\left(a^{x}+b^{x}+c^{x}\right)} .
$$

Innen a megoldás megegyezik az előzővel:

$$
\sqrt{a^{x}}+\sqrt{b^{x}}+\sqrt{c^{x}} \leq \sqrt{3\left(a^{x}+b^{x}+c^{x}\right)}
$$

amit négyzetre emelve, majd elosztva 2-vel, kapjuk, hogy

$$
\left(\sqrt{a^{x}}\right)^{2}+\left(\sqrt{b^{x}}\right)^{2}+\left(\sqrt{c^{x}}\right)^{2} \geq \sqrt{a^{x}} \cdot \sqrt{b^{x}}+\sqrt{b^{x}} \cdot \sqrt{c^{x}}+\sqrt{c^{x}} \cdot \sqrt{a^{x}},
$$

ami mindig igaz, és egyenlöség $a^{x}=b^{x}=c^{x}$ esetén áll fenn.

Ha $a=b=c$, akkor minden $x \in \mathbb{R}$ megoldás, ha pedig $a \neq b$, vagy $b \neq c$, vagy $c \neq a$, akkor csak $x=0$ megoldás. 


\subsubsection{Trigonometria}

Bizonyos egyenletek, illetve egyenletrendszerek esetén előnyös lehet valamilyen trigonometrikus helyettesítés elvégzése, majd az így kapott egyenletek trigonometriai úton való kezelése. Általában, ha az egyenletben $\sqrt{1-x^{2}}$ vagy $x^{2}+y^{2}$ alakú kifejezések jelennek meg, ahol $|x|,|y| \leq 1$, akkor érdemes megpróbálni az $x=\sin \alpha, y=\cos \alpha$ helyettesítést, míg $\sqrt{1+x^{2}}$ alakú kifejezés esetén az $x=\operatorname{tg} \alpha$ vagy az $x=\operatorname{ctg} \alpha$ helyettesítés vezethet célba.

\section{Órán megoldott feladatok}

4.1.37. Feladat. Oldd meg a $\frac{\sqrt{1-x^{2}}}{x}=3-4 x^{2}$ egyenletet!

\section{Kérdések:}

- Első ránézésre milyen megoldási ötleted lenne? Kivitelezhető-e ez?

- Próbálkozz más megoldással! Milyen helyettesítést sugall a bal oldali gyökkifejezés?

- A helyettesítést elvégezve hogyan tudnád megoldani a kapott egyenletet?

- Melyik megoldásmód előnyösebb? Miért?

1. megoldás: Létezési feltételek: $x \neq 0$ és $1-x^{2} \geq 0$, azaz $D=[-1,1] \backslash\{0\}$.

$$
\frac{\sqrt{1-x^{2}}}{x}=3-4 x^{2} \Longleftrightarrow \sqrt{1-x^{2}}=3 x-4 x^{3} \text {. }
$$

Mivel a bal oldal pozitív, ezért a jobb oldalnak is pozitívnak kell lennie, azaz $3 x-4 x^{3}=$ $x\left(3-4 x^{2}\right) \geq 0$, ahonnan a létezési feltételeket figyelembe véve $x \in\left[-1,-\frac{\sqrt{3}}{2}\right] \cup\left(0, \frac{\sqrt{3}}{2}\right]$.

Négyzetre emelés és átcsoportosítás után a

$$
16 x^{6}-24 x^{4}+10 x^{2}-1=0
$$

egyenlethez jutunk. Bevezetve a $t=x^{2}, t \geq 0$ jelölést, kapjuk, hogy

$$
16 t^{3}-24 t^{2}+10 t-1=0 .
$$

Észrevehető, hogy $t_{1}=\frac{1}{2}$ kielégíti az egyenletet, így a

$$
\left(t-\frac{1}{2}\right) \cdot\left(16 t^{2}-16 t+2\right)=0
$$

alakhoz jutunk, ahonnan $t_{2}=\frac{2-\sqrt{2}}{4}$ és $t_{3}=\frac{2+\sqrt{2}}{4}$. Tehát

$$
x_{1,2}= \pm \frac{\sqrt{2}}{2}, x_{3,4}= \pm \frac{\sqrt{2-\sqrt{2}}}{2}, x_{5,6}= \pm \frac{\sqrt{2+\sqrt{2}}}{2} .
$$

A létezési feltételek alapján

$$
M=\left\{-\frac{\sqrt{2+\sqrt{2}}}{2}, \frac{\sqrt{2-\sqrt{2}}}{2}, \frac{\sqrt{2}}{2}\right\} .
$$


2. megoldás: A négyzetgyök létezéséhez szükséges, hogy $x \in[-1,1]$ legyen. Így viszont létezik olyan $t \in\left[-\frac{\pi}{2}, \frac{\pi}{2}\right]$, amelyre $x=\sin t$. A tört létezéséhez $x \neq 0$, tehát $t \neq 0$. Elvégezve az

$$
x=\sin t, \quad t \in\left[-\frac{\pi}{2}, \frac{\pi}{2}\right]
$$

helyettesítést a

$$
\cos t=3 \sin t-4 \sin ^{3} t \quad \Longleftrightarrow \quad \cos t=\sin 3 t
$$

egyenlethez jutunk. Ez rendre a következőképpen alakítható:

$$
\begin{gathered}
\cos \left(\frac{\pi}{2}-3 t\right)-\cos t=0 \\
-2 \sin \left(\frac{\pi}{4}-t\right) \sin \left(\frac{\pi}{4}-2 t\right)=0,
\end{gathered}
$$

ahonnan a vizsgált intervallumba csak a

$$
t_{1}=\frac{\pi}{4}, \quad t_{2}=\frac{\pi}{8}, \quad t_{3}=-\frac{\pi}{8}
$$

megoldások esnek, tehát

$$
M=\left\{-\sin \frac{\pi}{8}, \sin \frac{\pi}{8}, \sin \frac{\pi}{4}\right\}
$$

A $\sin t=\sqrt{\frac{1-\cos 2 t}{2}}$ összefüggés alapján $\sin \frac{\pi}{8}=\frac{\sqrt{2-\sqrt{2}}}{2}$, így a megoldáshalmaz felírható

$$
M=\left\{-\frac{\sqrt{2+\sqrt{2}}}{2}, \frac{\sqrt{2-\sqrt{2}}}{2}, \frac{\sqrt{2}}{2}\right\}
$$

alakban is.

Megjegyzés: Mindkét módon megoldva a feladatot mérlegeltük egyik vagy másik módszer előnyét, esetleg hátrányát. A diákok belátták, hogy az algebrai megoldásnak mindenképpen hátránya, hogy eléggé magas fokú egyenlethez vezethet, amelynek nem mindig sikerül kitalálni megfelelő számú megoldását, és visszavezetni kisebb fokszámú egyenletre. Ezzel szemben a trigonometrikus megoldásmód sokszor előnyös, ötletes, viszont a trigonometriai azonosságok megfelelő ismeretét feltételezi.

4.1.38. Feladat. Oldd meg az $\left\{\begin{array}{l}x^{2}+y^{2}=1 \\ x+\sqrt{3} y=4 x y\end{array}\right.$ egyenletrendszert!

\section{Kérdések:}

- Milyen trigonometrikus helyettesítést sugall az első egyenlet?

- Hogy néz ki a helyettesítés után a második egyenlet? Meg tudnád oldani?

- Trigonometrikus helyettesítés nélkül elindulva megoldható-e az egyenletrendszer?

- Melyik megoldásmód előnyösebb? 
1. megoldás: Az első egyenlet trigonometrikus megoldásmódot sugall, ezért legyen

$$
x=\cos \alpha, \quad y=\sin \alpha, \quad \alpha \in[0,2 \pi) .
$$

A második egyenlet alapján

$$
\cos \alpha+\sqrt{3} \sin \alpha=4 \cos \alpha \sin \alpha \Longleftrightarrow \frac{1}{2} \cos \alpha+\frac{\sqrt{3}}{2} \sin \alpha=\sin 2 \alpha,
$$

azaz

$$
\sin \left(\frac{\pi}{6}+\alpha\right)=\sin 2 \alpha
$$

ahonnan

$$
\alpha \in\left\{\frac{\pi}{6}+2 k \pi \mid k \in \mathbb{Z}\right\} \cap\left\{\frac{(2 k+1) \pi}{3}-\frac{\pi}{18} \mid k \in \mathbb{Z}\right\}
$$

Tehát

$$
M=\left\{(\cos \alpha, \sin \alpha) \mid \alpha \in\left\{\frac{\pi}{6}, \frac{5 \pi}{18}, \frac{17 \pi}{18}, \frac{29 \pi}{18}\right\}\right\} .
$$

2. megoldás: Ha kifejezzük a második egyenletből $x$-et, majd behelyettesítjük az elsőbe, akkor a

$$
16 y^{4}-8 y^{3}-12 y^{2}+8 y-1=0
$$

negyedfokú egyenlethez jutunk. Némi próbálkozás után észrevehető, hogy $y_{1}=\frac{1}{2}$ gyöke az egyenletnek, így a bal oldal tényezők szorzatára bontható, és a

$$
(2 y-1)\left(8 y^{3}-6 y+1\right)=0 .
$$

alakot kapjuk. Itt viszont, hacsak nem használjuk a harmadfokú egyenlet megoldóképletét, tisztán algebrai úton dolgozva elakadunk. Viszont észrevehető, hogy

$$
8 y^{3}-6 y+1=0 \Leftrightarrow 2 \cdot\left(4 y^{3}-3 y\right)+1=0,
$$

így ha $y=\cos \alpha, \alpha \in[0,2 \pi)$, akkor $4 y^{3}-3 y=4 \cos ^{3} \alpha-3 \cos \alpha=\cos 3 \alpha$, és a

$$
\cos 3 \alpha=-\frac{1}{2}
$$

egyenlethez jutunk, ahonnan

$$
\alpha \in\left\{\frac{2 \pi}{9}, \frac{8 \pi}{9}, \frac{14 \pi}{9}\right\}
$$

Tehát

$$
M=\left\{(\sin \alpha, \cos \alpha) \mid \alpha \in\left\{\frac{\pi}{3}, \frac{2 \pi}{9}, \frac{8 \pi}{9}, \frac{14 \pi}{9}\right\}\right\} .
$$

Megjegyzés: Minden diák számára egyértelmüen az első megoldás tűnt egyszerübbnek, így egyetértettek azzal, hogy érdemes már a legelején elvégezni a megfelelő helyettesítéseket. Miután a célravezető helyettesítés megszületett, a számítások inkább a trigonometrikus azonosságok pontatlan ismerete miatt akadoztak.

4.1.39. Feladat. Oldd meg az $\left\{\begin{array}{l}x+y+z=x y z \\ \frac{4 \sqrt{x^{2}+1}}{x}=\frac{5 \sqrt{y^{2}+1}}{y}=\frac{6 \sqrt{z^{2}+1}}{z}\end{array}\right.$ egyenletrendszert! 


\section{Kérdések:}

- Milyen trigonometrikus helyettesítést sugallnak az egyenletekben szereplő kifejezések?

- Hogyan alakíthatók át az egyenletek a megfelelő helyettesítések elvégzése után?

- Mit tudsz mondani azokról a hegyesszögekről, amelyek tangensösszege megegyezik tangensszorzatával?

- Hogyan származtathatók a második egyenlet aránypárjai, hogy ismert trigonometrikus azonosságokhoz juthassunk?

Megoldás: Észrevehető, hogy $x, y, z$ azonos előjelü kell legyen, ugyanakkor ha $\left(x_{0}, y_{0}, z_{0}\right)$ megoldása a rendszernek, akkor $\left(-x_{0},-y_{0},-z_{0}\right)$ is az, ezért csak az $x, y, z>0$ esettel foglalkozunk.

Mivel $x, y, z>0$, ezért létezik $\alpha, \beta, \gamma \in\left(0, \frac{\pi}{2}\right)$ úgy, hogy $x=\operatorname{tg} \alpha, y=\operatorname{tg} \beta, z=\operatorname{tg} \gamma$. Ekkor

$$
\left\{\begin{array} { l } 
{ x + y + z = x y z } \\
{ \frac { 4 \sqrt { x ^ { 2 } + 1 } } { x } = \frac { 5 \sqrt { y ^ { 2 } + 1 } } { y } = \frac { 6 \sqrt { z ^ { 2 } + 1 } } { z } }
\end{array} \Longleftrightarrow \left\{\begin{array}{l}
\alpha+\beta+\gamma=\pi \\
\frac{4}{\sin \alpha}=\frac{5}{\sin \beta}=\frac{6}{\sin \gamma}
\end{array}\right.\right.
$$

Megfelelően alakítva az aránypárokat

$$
\frac{4}{\sin \alpha}=\frac{5}{\sin \beta}=\frac{6}{\sin \gamma} \Longleftrightarrow \frac{4 \cos \beta}{\sin \alpha \cos \beta}=\frac{5 \cos \alpha}{\sin \beta \cos \alpha}=\frac{6}{\sin (\alpha+\beta)}
$$

ahonnan kapjuk, hogy

$$
5 \cos \alpha+4 \cos \beta=6,
$$

ugyanakkor

$$
\frac{4}{\sin \alpha}=\frac{5}{\sin \beta}=\frac{6}{\sin \gamma} \Longleftrightarrow \frac{4 \sin \beta}{\sin \alpha \sin \beta}=\frac{5 \sin \alpha}{\sin \beta \sin \alpha}=\frac{6}{\sin (\alpha+\beta)},
$$

ahonnan

$$
5 \sin \alpha=4 \sin \beta .
$$

Ezt négyzetre emelve, majd áttérve koszinuszra kapjuk, hogy

$$
(5 \cos \alpha+4 \cos \beta)(5 \cos \alpha-4 \cos \beta)=9 \text {. }
$$

Figyelembe véve a (4.1) összefüggést a fentiből következik, hogy

$$
5 \cos \alpha-4 \cos \beta=\frac{3}{2} \text {. }
$$

A (4.1) és a (4.2) összefüggésekből

$$
\cos \alpha=\frac{3}{4} \quad \text { és } \quad \cos \beta=\frac{9}{16} .
$$


Tudva, hogy $\alpha, \beta, \gamma \in\left(0, \frac{\pi}{2}\right)$, a trigonometria alaptételét felhasználva kapjuk, hogy

$$
\sin \alpha=\frac{\sqrt{7}}{4} \quad \text { és } \quad \cos \beta=\frac{5 \sqrt{7}}{16} .
$$

A (4.3) és a (4.4) alapján

$$
x=\operatorname{tg} \alpha=\frac{\sqrt{7}}{3}, \quad y=\operatorname{tg} \beta=\frac{5 \sqrt{7}}{9} \quad \text { és } \quad z=\operatorname{tg} \gamma=3 \sqrt{7} .
$$

Tehát

$$
M=\left\{\left(\frac{\sqrt{7}}{3}, \frac{5 \sqrt{7}}{9}, 3 \sqrt{7}\right),\left(-\frac{\sqrt{7}}{3},-\frac{5 \sqrt{7}}{9},-3 \sqrt{7}\right)\right\} .
$$

Megjegyzés: Úgy a tigonometrikus helyettesítés, mint a kapott összefüggések megfelelő alakítása önálló munkára nehéznek bizonyult, így lényegében közösen oldottuk meg a feladatot.

\section{Házi feladatok}

4.1.40. Feladat. Mekkora az $a^{6}+b^{6}$ legkisebb és legnagyobb értéke, ha a és b olyan valós számok, amelyekre $a^{2}+b^{2}=1$ ?

1. megoldás. Mivel $a^{2}+b^{2}=1$, ezért $a \in[-1,1]$ és $b \in[-1,1]$. Ekkor

$$
a^{6}+b^{6}=a^{6}+\left(1-a^{2}\right)^{3}=3 a^{4}-3 a^{2}+1=3\left(a^{2}-\frac{1}{2}\right)^{2}+\frac{1}{4}
$$

Ebből látszik, hogy a kifejezés minimuma $\frac{1}{4}$, maximuma 1 .

2. megoldás. Mivel $a^{2}+b^{2}=1$, ezért $a, b \in[-1,1]$ és $\exists \alpha \in[0,2 \pi)$ úgy, hogy $\cos \alpha=a$ és $\sin \alpha=b$. Ekkor

$$
\cos ^{6} \alpha+\sin ^{6} \alpha=\left(\cos ^{2} \alpha+\sin ^{2} \alpha\right)\left[\left(\cos ^{2} \alpha+\sin ^{2} \alpha\right)^{2}-3(\cos \alpha \sin \alpha)^{2}\right],
$$

és felhasználva, hogy $\cos ^{2} \alpha+\sin ^{2} \alpha=1$, kapjuk, hogy

$$
\cos ^{6} \alpha+\sin ^{6} \alpha=1-3\left(\frac{\sin 2 \alpha}{2}\right)^{2} \text {. }
$$

Mivel $\sin 2 \alpha \in[-1,1]$, ezért a kifejezés minimuma $\frac{1}{4}$, maximuma pedig 1 .

4.1.41. Feladat. Oldd meg a $2 x \sqrt{1-x^{2}}-\sqrt{3}\left(1-2 x^{2}\right)=1$ egyenletet!

Megoldás. A létezési feltétel $1-x^{2} \geq 0$, ahonnan $x \in[-1,1]$. Ez sugallja az

$$
x=\sin t, \quad t \in\left[-\frac{\pi}{2}, \frac{\pi}{2}\right]
$$

helyettesítést. Ekkor a

$$
2 \sin t \sqrt{1-\sin ^{2} t}-\sqrt{3}\left(1-2 \sin ^{2} t\right)=1
$$


egyenlethez jutunk, ami

$$
\sqrt{1-\sin ^{2} t}=\sqrt{\cos ^{2} t}=|\cos t|=\cos t, \quad \forall t \in\left[-\frac{\pi}{2}, \frac{\pi}{2}\right]
$$

miatt

$$
\sin 2 t-\sqrt{3} \cos 2 t=1
$$

alakba hozható. Ezt végigosztva 2-vel, majd a bal oldalt a segédszög módszerével átalakítva

$$
\sin \left(2 t-\frac{\pi}{3}\right)=\frac{1}{2}
$$

egyszerü trigonometrikus egyenlethez jutunk, melynek általános megoldása

$$
t \in\left\{\frac{\pi}{4}+k \pi \mid k \in \mathbb{Z}\right\} \cup\left\{\frac{7 \pi}{12}+k \pi \mid k \in \mathbb{Z}\right\} .
$$

Ezek közül a

$$
\frac{\pi}{4},-\frac{5 \pi}{12} \in\left[-\frac{\pi}{2}, \frac{\pi}{2}\right]
$$

így

$$
x=\sin \frac{\pi}{4}=\frac{\sqrt{2}}{2},
$$

és

$$
x=\sin \left(-\frac{5 \pi}{12}\right)=-\frac{\sqrt{2+\sqrt{3}}}{2} .
$$

Tehát

$$
M=\left\{-\frac{\sqrt{2+\sqrt{3}}}{2}, \frac{\sqrt{2}}{2}\right\} .
$$

4.1.42. Feladat. Igazold, hogy bármely $x \in[-1,1]$ esetén

a) $\sqrt{1 \pm x}+\sqrt{2} \cdot \sqrt{1+\sqrt{1-x^{2}}}=\sqrt{5 \pm 3 x+4 \sqrt{1-x^{2}}}$

b) $\sqrt{1 \pm \sqrt{1-x^{2}}}+\sqrt{2} \cdot \sqrt{1+x}=\sqrt{5+4 x \pm 3 \sqrt{1-x^{2}}}$

Megoldás. A 4.1.37., a 4.1.38. és az előző feladat megoldásában használt helyettesítéssel, teljesen hasonló módszerrel oldható meg mind a négy egyenlet.

4.1.43. Feladat. Oldd meg a következö egyenletrendszereket!
a) $\left\{\begin{array}{l}x+y+z=x y z \\ \frac{x}{\sqrt{1+x^{2}}}+\frac{y}{\sqrt{1+y^{2}}}+\frac{z}{\sqrt{1+z^{2}}}=\frac{3 \sqrt{3}}{2}\end{array}\right.$
b) $\left\{\begin{array}{l}x+y+z=x y z \\ \frac{1}{\sqrt{1+x^{2}}}+\frac{1}{\sqrt{1+y^{2}}}+\frac{1}{\sqrt{1+z^{2}}}=\frac{3}{2}\end{array}\right.$

Megoldás. A 4.1.39. feladat megoldásában használt helyettesítéssel, teljesen hasonló módszerrel oldható meg mindkét egyenletrendszer. 


\subsection{Geometriai problémák - algebrai eszközök}

A második stratégia szemléletében az előzőnek éppen a fordítottja: geometriai szövegezésű feladatok algebrai eszközökkel való megközelítése. Az előző részhez képest a diákoknak talán valamennyivel természetesebb a geometriai jellegü problémák algebrai úton való tárgyalása. Ez sajnos nem azt jelenti, hogy sokkal hatékonyabban és eredményesebben kezelnék az ilyen jellegű problémákat, csupán annyit, hogy az ebbe az irányba való váltás az iskolai gyakorlatban megszokottabb a fordított irányhoz képest.

Célom ennek a stratégiának a tanításával annak illusztrálása volt, hogy tipikusan geometriai szövegezésú feladatok megoldása, néha - részben vagy teljes egészében - algebrai eszközrendszer bevetését kívánja. Igyekeztem bemutatni azokat a lehetőségeket, amelyek ilyen esetekben hasznosak, eredményesek lehetnek, ezáltal fejlesztve, gazdagítva a diákok problémamegoldó eszköztárát.

\subsubsection{A Descartes-féle koordináta-rendszer felhasználása}

$\mathrm{Az}$ analitikus mértan a geometriának az algebrához legközelebb álló része, tulajdonképpen egyfajta algebra, hiszen a koordináta-rendszer megfelelő megválasztása után, az objektumok közötti geometriai viszony algebrai eszközökkel vizsgálható. A nyilvánvalóság kizárása érdekében igyekeztem olyan mértanfeladatokat választani, amelyek szövegezése nem árulkodik koordináták bevezetéséről, tehát nem szerepelnek benne például koordinátákkal megadott pontok. Így az alábbi feladatok megoldása során a nehézséget minden esetben inkább a vizsgált alakzatoknak a koordináta-rendszerben való megfelelő elhelyezése okozta. A tanulmányozott objektumok rögzítése után, az azok közötti viszonyok leírása és a kért összefüggések bizonyítása már egyszerủbben ment.

\section{Órán megoldott feladatok}

4.2.1. Feladat. Legyen egy derékszögü háromszög egyik befogója egy kocka éle, a másik befogója pedig ugyanannak a kockának a lapátlója. Bizonyítsd be, hogy a háromszögnek két súlyvonala merőleges egymásra!

\section{Kérdések:}

- Mit állít a feladat a háromszögről? Mi a kérés?

- Miben lenne érdemes dolgozni? Hogyan választanád meg ezt?

- Hogyan tudnád jellemezni a súlyvonalakat?

- Mi a feltétele annak, hogy két egyenes vagy két vektor merőleges legyen?

Megoldás: Ha a kocka éle $a$, akkor a háromszög befogói $a$ és $a \sqrt{2}$. Helyezzük el a háromszöget a derékszögü koordináta-rendszerben úgy, hogy $A(a, 0), B(0, a \sqrt{2})$ és $C(0,0)$ legyen. (4.29. ábra)

Ekkor a $[B C]$ felezőpontja $A^{\prime}\left(0, \frac{a \sqrt{2}}{2}\right)$, az $[A B]$ felezópontja pedig $C^{\prime}\left(\frac{a}{2}, \frac{a \sqrt{2}}{2}\right)$, így

$$
\overrightarrow{A A^{\prime}}=\left(-a, \frac{a \sqrt{2}}{2}\right) \quad \text { és } \quad \overrightarrow{C C^{\prime}}=\left(\frac{a}{2}, \frac{a \sqrt{2}}{2}\right) \text {. }
$$




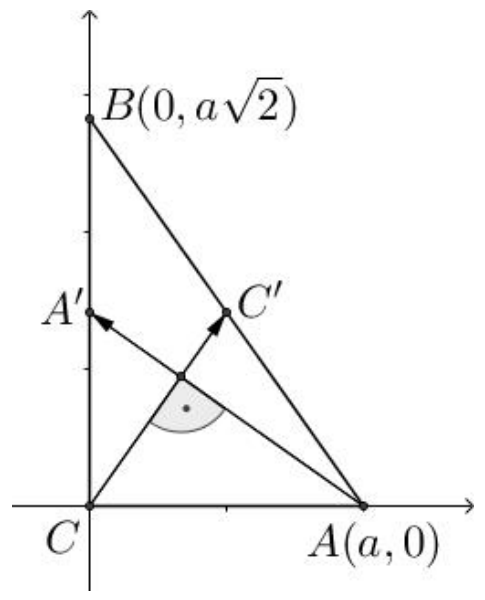

4.29. ábra. A derékszögü háromszög

Mivel

$$
\overrightarrow{A A^{\prime}} \cdot \overrightarrow{C C^{\prime}}=-\frac{a^{2}}{2}+\frac{a^{2}}{2}=0
$$

ezért $\overrightarrow{A A^{\prime}} \perp \overrightarrow{C C^{\prime}}$, tehát két súlyvonal merőleges egymásra.

Megjegyzés: A koordináta-rendszer megfelelő megválasztása után a feladat nem okozott gondot a diákoknak, így önállóan be tudták bizonyítani a feladatban megfogalmazott tulajdonságot.

4.2.2. Feladat. $A z A B C$ egyenlő szárú háromszögben $A B=A C . A[B C]$ szakasz $D$ felezöpontjából az $A C$ oldalra bocsátott meröleges talppontja legyen $E$. A $[D E]$ felezöpontját jelölje F. Igazold, hogy $A F \perp B E$.

\section{Kérdések:}

- Mit állít és mit kér a feladat?

- Hogyan lenne érdemes elhelyezni a háromszöget a koordináta-rendszerben?

- Hogyan tudnád jellemezni az $A F$ és $B E$ egyeneseket?

- Hogyan bizonyítanád, hogy merőlegesek?

Megoldás: Helyezzük el a háromszöget a derékszögű koordináta-rendszerben úgy, hogy szimmetriatengelye az $O y$ tengely legyen, és $D$ az origóba essen. (4.30. ábra)

Ekkor $A(0, a), B(-b, 0)$ és $C(b, 0)$. Mivel az $A C$ egyenes iránytényezője $m_{A C}=-\frac{a}{b}$, a $D E$ egyenes egyenlete $b x-a y=0$ lesz, ahonnan

$$
E\left(\frac{a^{2} b}{a^{2}+b^{2}}, \frac{a b^{2}}{a^{2}+b^{2}}\right), \quad \text { így } F\left(\frac{a^{2} b}{2\left(a^{2}+b^{2}\right)}, \frac{a b^{2}}{2\left(a^{2}+b^{2}\right)}\right) .
$$

Végül

$$
\overrightarrow{B E}\left(\frac{2 a^{2} b+b^{3}}{a^{2}+b^{2}}, \frac{a b^{2}}{a^{2}+b^{2}}\right) \quad \text { és } \quad \overrightarrow{A F}\left(\frac{a^{2} b}{2\left(a^{2}+b^{2}\right)},-\frac{2 a^{3}+a b^{2}}{2\left(a^{2}+b^{2}\right)}\right) \text {. }
$$




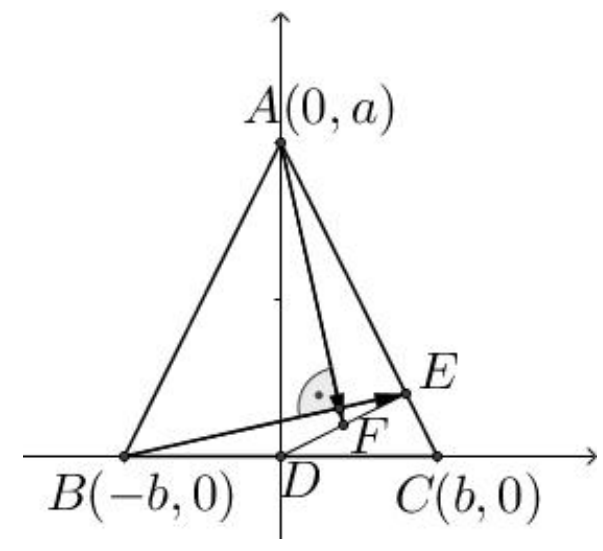

4.30. ábra. Az egyenlő szárú háromszög

Mivel $\overrightarrow{B E} \cdot \overrightarrow{A F}=0$, ezért $B E \perp A F$.

Megjegyzés: A feladat a diákok tudásának megfelelő nehézségünek bizonyult, így mindenki helyesen meg tudta választani a koordináta-rendszert, és sikeresen bizonyította a merölegességet.

4.2.3. Feladat. $A z A B C D$ téglalap $A$ és $C$ csúcsain keresztül párhuzamosokat, ezekre a másik két csúcsból merőlegeseket húzunk. Bizonyítsd be, hogy a keletkezett téglalap középpontja egybeesik az eredeti téglalap középpontjával!

\section{Kérdések:}

- Mit állít és mit kér a feladat?

- Hogyan lenne érdemes elhelyezni a téglalapot a koordináta-rendszerben?

- Hogyan jellemeznéd a téglalap középpontját?

- Ki tudnád számítani a keletkező téglalap középpontjának koordinátáit?

Megoldás: Legyen $A(a, 0), B(a, b), C(0, b)$ és $D(0,0)$. (4.31. ábra) Ekkor

$$
A C \cap B D=K\left(\frac{a}{2}, \frac{b}{2}\right) .
$$

A 4.31. ábra jelölései szerint $e_{1}\left\|e_{2}, e_{3}\right\| e_{4}$, és $e_{2} \perp e_{4}$, így

$$
e_{2}: \quad y=m x \quad e_{4}: \quad y=-\frac{1}{m}(x-a) .
$$

Ekkor

$$
e_{2} \cap e_{4}=\left\{A_{1}\right\}, \quad A_{1}\left(\frac{a}{m^{2}+1}, \frac{m a}{m^{2}+1}\right) .
$$

Ugyanakkor

$$
\begin{gathered}
e_{1}: \quad y-b=m(x-a) \quad \Longleftrightarrow \quad y=m x-m a+b, \\
e_{3}: \quad y=-\frac{1}{m} x+b .
\end{gathered}
$$




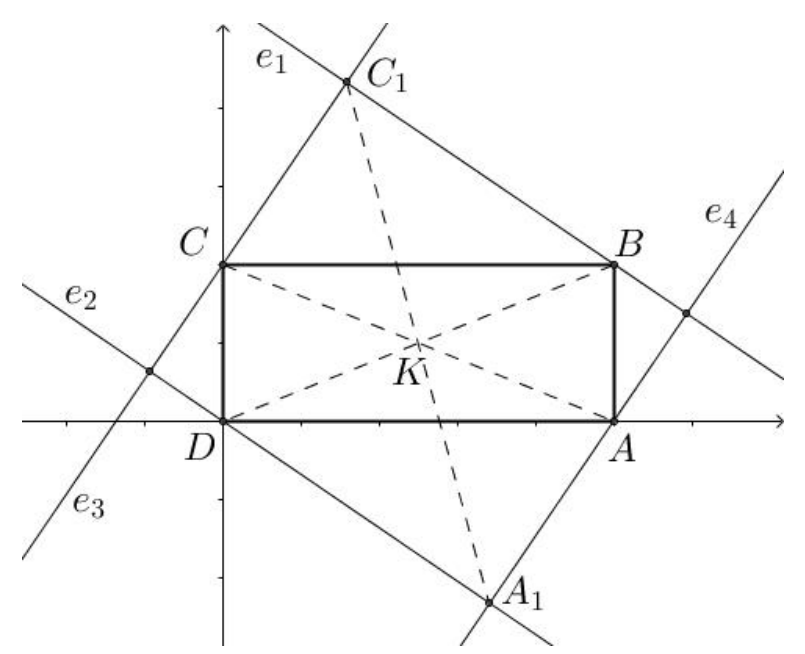

4.31. ábra. A téglalapok középpontjai

Mivel $e_{1} \cap e_{3}=\left\{C_{1}\right\}$, ezért

$$
C_{1}\left(\frac{m^{2} a}{m^{2}+1}, \frac{\left(m^{2}+1\right) b-m a}{m^{2}+1}\right) .
$$

$\mathrm{Az}\left[A_{1} C_{1}\right]$ szakasz $K_{1}\left(x_{1}, y_{1}\right)$ felezöpontja egybeesik $K$-val, mert

$$
x_{1}=\frac{1}{2}\left(\frac{a}{m^{2}+1}+\frac{m^{2} a}{m^{2}+1}\right)=\frac{a}{2}, \quad y_{1}=\frac{1}{2}\left(\frac{m a}{m^{2}+1}+\frac{\left(m^{2}+1\right) b-m a}{m^{2}+1}\right)=\frac{b}{2} .
$$

Megjegyzés: Bár a feladat nem igérkezett nehezebbnek az előzőeknél, mégis a számítások valamivel nagyobb komplexitása miatt, sokan hibásan számították ki az új téglalap koordinátáit, emiatt végül sok időbe telt a bizonyítás tökéletes kivitelezése.

4.2.4. Feladat. Egy egyenlö szárú derékszögü háromszögbe téglalapot írunk úgy, hogy a téglalap két oldala a két befogóra illeszkedjék. A téglalap átfogóra eső csúcsából merőlegest bocsátunk a szemközti átlójára. Mutasd ki, hogy, a téglalap megválasztásától függetlenül, a merőleges egy rögzített ponton halad át!

\section{Kérdések:}

- Mit állít és mit kér a feladat?

- Hogyan lenne érdemes elhelyezni a háromszöget a koordináta-rendszerben?

- Meg tudnád határozni ekkor a téglalap csúcsainak koordinátáit?

- Hogyan jellemeznéd a téglalap átfogóra eső csúcsából az átlóra húzott merőlegest?

- Meg tudnád határozni a fixpont koordinátáit? 


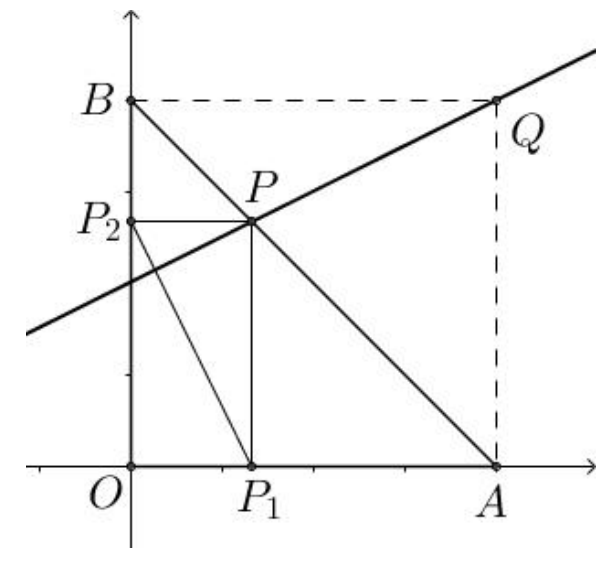

4.32. ábra.

Megoldás: A 4.32. ábra szerint legyenek $A(a, 0)$ és $B(0, a)$ az átfogó végpontjai, valamint $P_{1}(p, 0)$ és $P_{2}(0, a-p)$ a téglalap befogókra eső csúcsai $(p<a)$. Ekkor $P(p, a-p)$ és $\overrightarrow{P_{2} P_{1}}=(p, p-a)$. A $P$-ből a $P_{1} P_{2}$-re bocsátott merőleges egyenlete:

$$
p x+(p-a) y=p^{2}-(p-a)^{2} \Longleftrightarrow p x+(p-a) y=2 p a-a^{2} .
$$

Mivel bármilyen $p<a$ esetén a $Q(a, a)$ pont koordinátái kielégítik az egyenes egyenletét, ezért a $P$ megválasztásától függetlenül ezen egyenesek áthaladnak a $Q$ ponton.

Megjegyzés: A feladat tetszett a diákoknak, még a konkrét számítások előtt nagy érdeklődéssel kezdték el kikísérletezni a fixpont helyét, melyet többen helyesen meg is sejtettek. A háromszög célszerű elhelyezése a koordináta-rendszerben, és a számítások kivitelezése nem okozott jelentős problémákat.

4.2.5. Feladat. Legyen az $A B C$ háromszög belsejében $P$ egy olyan pont, amelyre az $A B P, B C P$ és $A C P$ háromszögek területe egyenlö. Milyen pontja $P$ a háromszögnek?

\section{Kérdések:}

- Hogyan helyeznéd el a háromszöget a koordináta-rendszerben?

- Milyen sejtésed van? Tudnád ezt bizonyítani? Mit kellene ennek belátása érdekében kiszámítani?

- Felhasználtál a feladat adta minden feltételt?

Megoldás: Legyen $A(0,0), B(b, 0), C(c, d)(b, c, d>0)$ és $P\left(x_{P}, y_{P}\right)$. (4.33. ábra)

Tudjuk, hogy

$$
T_{A B P}=T_{B C P}=T_{A C P}=\frac{1}{3} T_{A B C}
$$

Ugyanakkor

$$
T_{A B C}=\frac{b \cdot d}{2} \quad \text { és } \quad T_{A B P}=\frac{b \cdot y_{P}}{2}=\frac{1}{3} \cdot \frac{b \cdot d}{2} \quad \Longrightarrow \quad y_{P}=\frac{d}{3} .
$$




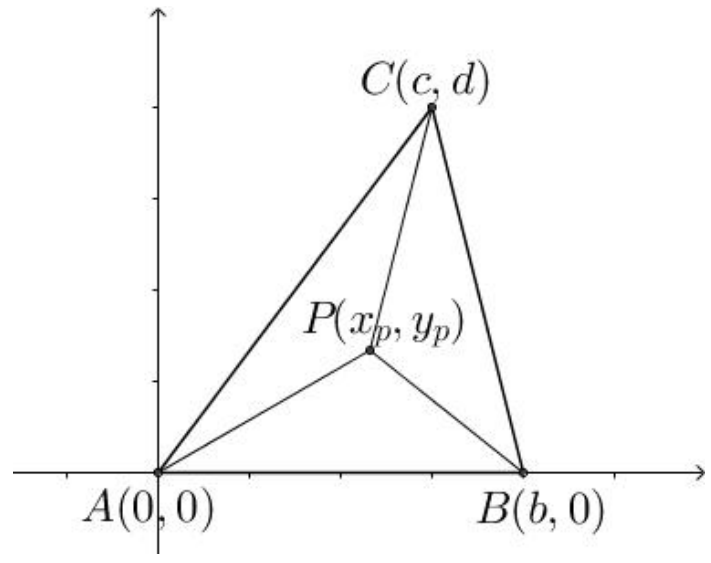

4.33. ábra.

Az abszcissza meghatározása érdekében kiszámítjuk a $B$, illetve a $P$ pontnak a távolságát az $A C$ oldaltól, hiszen a területekre vonatkozó összefüggés miatt, az utóbbi harmada az előbbinek. Mivel

$$
A C: \quad d x-c y=0,
$$

ezért

$$
d(B, A C)=\frac{b d}{\sqrt{d^{2}+c^{2}}} \quad \text { és } \quad d(P, A C)=\frac{d \cdot x_{P}-c \cdot y_{P}}{\sqrt{d^{2}+c^{2}}}=\frac{d \cdot x_{P}-c \cdot \frac{d}{3}}{\sqrt{d^{2}+c^{2}}} .
$$

De $d(B, A C)=3 \cdot d(P, A C)$ miatt

$$
b d=3\left(d \cdot x_{P}-c \cdot \frac{d}{3}\right) \quad \Longrightarrow \quad x_{P}=\frac{b+c}{3} \quad \Longrightarrow \quad P\left(\frac{b+c}{3}, \frac{d}{3}\right)
$$

ami éppen a háromszög súlypontja.

Megjegyzés: A diákok közül néhányan ismerték a súlypontnak a feladatban szereplő tulajdonságát, így csupán indokolniuk kellett azt. A számítások kivitelezése viszont a vártnál nehézkesebben ment. A fenti analitikus bizonyítás után szintetikus geometriai bizonyításokra is kitértünk.

\section{Házi feladatok}

4.2.6. Feladat. Rajzoljunk egy háromszög mindkét befogója fölé kifelé egy-egy négyzetet, majd az átfogó végpontjait kössük össze a szemközti befogóra rajzolt négyzet távolabbi csúcsával. Bizonyítsd be, hogy az így adódó két egyenes az átfogóhoz tartozó magasságvonalon metszi egymást!

Megoldás. Helyezzük el a háromszöget a derékszögű koordináta-rendszerben úgy, hogy a derékszög csúcsa az origó, a másik két csúcsa pedig $A(a, 0)$, ill. $B(0, b)$ legyen. (4.34. ábra) Ekkor az átfogóhoz tartozó magasság egyenlete $y=\frac{a}{b} x$.

Az $O A$ vízszintes befogóra rajzolt négyzet $A^{\prime}(a,-a)$ csúcsát a $B(0, b)$ ponttal összekötő egyenes egyenlete:

$$
(a+b) x+a y=a b .
$$




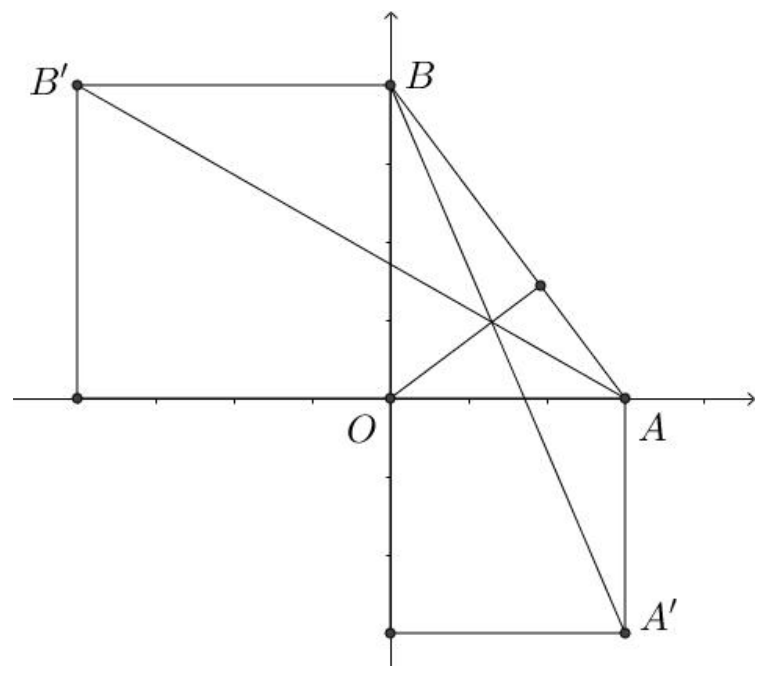

4.34. ábra.

Az $O B$ függóleges befogóra rajzolt négyzet $B^{\prime}(-b, b)$ csúcsát az $A(a, 0)$ ponttal összekötő egyenes egyenlete pedig:

$$
b x+(a+b) y=a b .
$$

A két egyenletet kivonva egymásból $a x-b y=0$, vagy $y=\frac{a}{b} x$ egyenlethez jutunk, ami éppen azt jelenti, hogy a két egyenes közös pontja rajta van a magasságvonalon.

4.2.7. Feladat. Igazold, hogy az ABCD téglalap síkjában felvett tetszőleges $P$ pontra teljesül, hogy

$$
A P^{2}+C P^{2}=B P^{2}+D P^{2}
$$

Megoldás. Legyen $A(0,0), B(b, 0), C(b, a), D(0, a)$ és $P(x, y)$. Az állítás igaz, hiszen

$$
\begin{aligned}
& A P^{2}+C P^{2}=x^{2}+y^{2}+(x-b)^{2}+(y-a)^{2}, \\
& B P^{2}+D P^{2}=(x-b)^{2}+y^{2}+x^{2}+(y-a)^{2} .
\end{aligned}
$$

4.2.8. Feladat. $A z A B C$ egyenlő oldalú háromszög $G$ súlypontját kössük össze a $B$ és $C$ csúcsokkal. Bizonyítsd be, hogy a $[G B]$ és $[G C]$ szakaszok felezömerölegesei a $[B C]$ szakaszt három egyenlö hosszúságú részre osztják!

Megoldás. Helyezzük a háromszöget úgy a koordináta-rendszerbe, hogy a $[B C]$ oldal felezőpontja az origóba essen, és legyen $A(0, a \sqrt{3}), B(-a, 0), C(a, 0)$. (4.35. ábra)

Ekkor $G\left(0, \frac{a \sqrt{3}}{3}\right)$ és a $[G C]$ felezöpontja $F_{1}\left(\frac{a}{2}, \frac{a \sqrt{3}}{6}\right)$. A $[G C]$ felezőmerőlegesének egyenlete:

$$
3 x-\sqrt{3} y=a .
$$

Ez az egyenes a $[B C]$ szakaszt a $P_{1}\left(\frac{a}{3}, 0\right)$ pontban metszi, tehát a $C$ ponthoz közelebbi harmadolóponton halad át. 


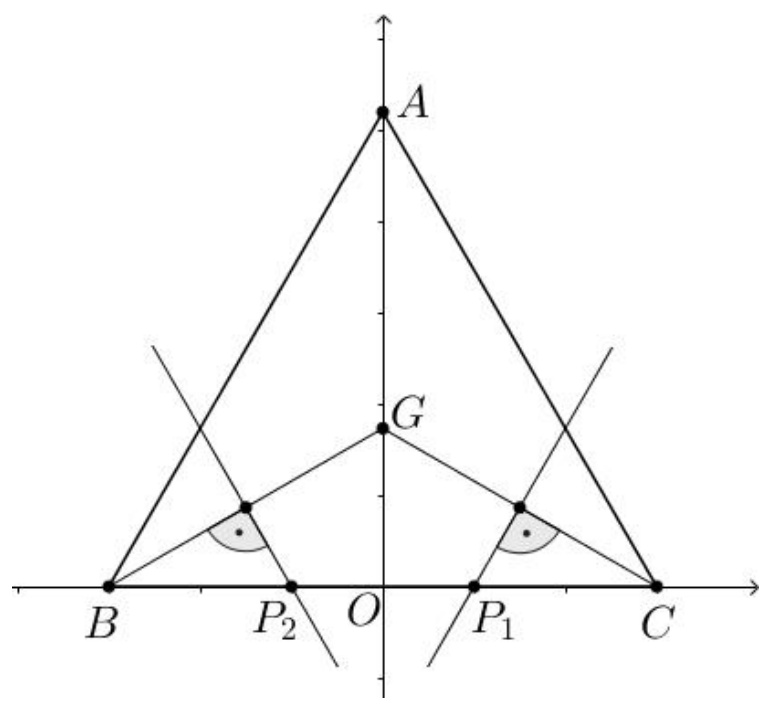

4.35. ábra.

Hasonlóan a $[G B]$ felezőpontja $F_{2}\left(-\frac{a}{2}, \frac{a \sqrt{3}}{6}\right)$, és a $[G B]$ felezőmerőlegesének egyenlete:

$$
3 x+\sqrt{3} y=-a .
$$

Ez az egyenes a $[B C]$ szakaszt a $P_{2}\left(-\frac{a}{3}, 0\right)$ pontban metszi, tehát a $B$ ponthoz közelebbi harmadolóponton halad át.

4.2.9. Feladat. $A z A B C D$ téglalap $B A D$ szögének felezöje a $B D$ átlót az $M, a B C$ oldal tartóegyenesét pedig a $P$ pontban metszi. Az $M$ ponton áthaladó $A B$-vel párhuzamos egyenes az $A C$ átlót $N$-ben metszi. Mutasd ki, hogy $P N \perp B D$.

Megoldás. Legyen $A(0,0), B(b, 0), C(b, a), D(0, a)$. (4.36. ábra) Ekkor a $B A D$ szög felezője éppen az első szögfelező, így egyenlete $y=x$, és $P(b, b)$. A $B D$ átló egyenlete $a x+b y=a b$.

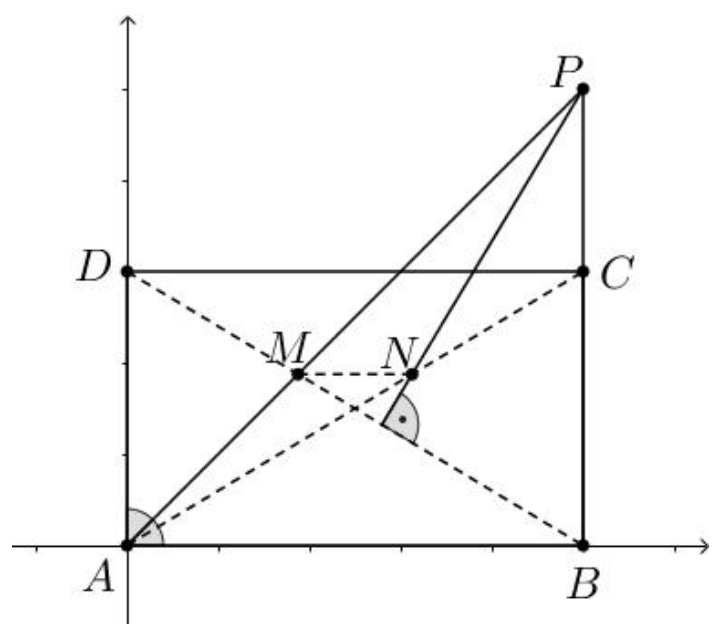

4.36. ábra. 


$$
B D \cap A P=\{M\} \quad \Longrightarrow \quad M\left(\frac{a b}{a+b}, \frac{a b}{a+b}\right) .
$$

Az $A C$ átló egyenlete $a x-b y=0$, és mivel $y_{N}=y_{M}=\frac{a b}{a+b}$, valamint

$$
N \in A C \quad \Longrightarrow \quad x_{N}=\frac{b^{2}}{a+b} \quad \Longrightarrow \quad N\left(\frac{b^{2}}{a+b}, \frac{a b}{a+b}\right) .
$$

Ekkor

$$
\overrightarrow{D B}=(b,-a) \quad \text { és } \quad \overrightarrow{N P}=\left(\frac{a b}{a+b}, \frac{b^{2}}{a+b}\right),
$$

ahonnan $\overrightarrow{D B} \cdot \overrightarrow{N P}=0$, tehát $P N \perp B D$.

4.2.10. Feladat. $A z O A=a$ és $O B=b$ befogójú derékszögü háromszög $A B$ átfogóján mozog a P pont, amelynek a befogókra eső meröleges vetületei $M$, illetve $N$. Hogyan válasszuk meg $P$ helyét, hogy a $P M^{2}+P N^{2}$ minimális legyen?

Megoldás. Legyen a derékszög csúcsa az origóban és $A(a, 0), B(0, b)$ az átfogó végpontjai. Ha $P(x, y)$, akkor $M(x, 0)$ és $N(0, y)$. Ekkor

$$
P M^{2}+P N^{2}=x^{2}+y^{2}=O P^{2},
$$

és $O P$ akkor minimális, ha $O P \perp A B$. Az $O A B$ derékszögü háromszög, így magassága

$$
m=\frac{O A \cdot O B}{A B}=\frac{a b}{\sqrt{a^{2}+b^{2}}} .
$$

Tehát a keletkezett minimum $\frac{a b}{\sqrt{a^{2}+b^{2}}}$, és $P$ a derékszögből húzott magasság talppontja kell legyen.

\subsubsection{A Gauss-féle komplex számsík alkalmazása}

A komplex számok segítségével megoldható feladatok tulajdonképpen minden esetben koordinátageometriai eszközökkel is megoldhatók, hiszen a Gauss-féle komplex számsík és a Descartes-féle derékszögü koordináta-rendszer ekvivalenciája miatt egy pont affixumának valós, illetve imaginárius része, annak koordinátáival egyenértékű.

Ennek ellenére bizonyos esetekben, föleg ha a feladatban valamilyen objektumok elforgatása szerepel, célszerúbb a komplex számsíkon dolgozni, hiszen két komplex szám szorzata geometriailag forgatva nyújtást jelent. Így aztán forgatások segítségével sok esetben könnyen igazolható valamilyen alakzat szabályos volta vagy két egyenes merőlegessége, esetleg párhuzamossága.

\section{Órán megoldott feladatok}

4.2.11. Feladat. $A z A B C D E F$ szabályos hatszögben a $[B C]$ felezöpontja $G, a[D F]$ átló felezöpontja $H$. Bizonyítsd be, hogy AGH háromszög szabályos. Mennyi a háromszög és a hatszög területének aránya? 


\section{Kérdések:}

- Mi van megadva és mit kér a feladat?

- Hogyan helyeznéd el a hatszöget a komplex számsíkon?

- Meg tudnád határozni a pontok affixumait?

- Mi a feltétel annak, hogy három pont egy szabályos háromszög csúcsait alkossa?

- Milyen más lehetőségek vannak?

Megoldás: Helyezzünk el egy egység oldalú szabályos hatszöget a komplex számsíkon úgy, hogy a középpontja az origó legyen, továbbá az $A$ csúcs affixuma az $a=1$ komplex szám legyen. (4.37. ábra)

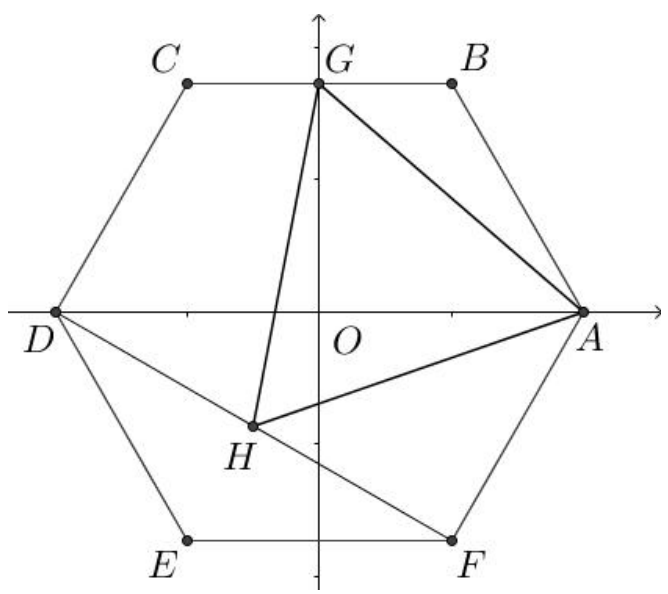

4.37. ábra. A szabályos hatszög

Ekkor

$$
b=\cos 60^{\circ}+i \sin 60^{\circ}=\frac{1}{2}+i \frac{\sqrt{3}}{2}, \quad c=\cos 120^{\circ}+i \sin 120^{\circ}=-\frac{1}{2}+i \frac{\sqrt{3}}{2},
$$

így

$$
g=\frac{b+c}{2}=\frac{\sqrt{3}}{2} i
$$

Mivel $d=-1$ és $f=\bar{b}$, ezért

$$
h=\frac{d+f}{2}=-\frac{1}{4}-i \frac{\sqrt{3}}{4} .
$$

Az $A G H$ háromszög szabályos, ha a $G$ pontot $+60^{\circ}$-kal elforgatva az $A$ körül, a $H$ pontot kapjuk, azaz

$$
h=(g-a)\left(\cos 60^{\circ}+i \sin 60^{\circ}\right)+a .
$$

Behelyettesítve a pontok affixumait

$$
h=\left(-1+i \frac{\sqrt{3}}{2}\right)\left(i \frac{1}{2}+i \frac{\sqrt{3}}{2}\right)+1=-\frac{1}{4}-i \frac{\sqrt{3}}{4},
$$


ami igaz, tehát $A G H$ szabályos. Területének és a hatszög területének aránya

$$
\frac{T_{A G H}}{T_{A B C D E F}}=\frac{|a-g|^{2}}{6}=\frac{\sqrt{1^{2}+\frac{3}{4}}}{6}=\frac{\sqrt{7}}{12} .
$$

Az $A G H$ háromszög szabályossága úgy is igazolható, hogy belátjuk, hogy hasonló önmagával, azaz $A G H_{\triangle} \sim G H A_{\triangle}$, amely akkor és csak akkor teljesül, ha

$$
\frac{a-h}{g-h}=\frac{g-a}{h-a} \Longleftrightarrow a^{2}+g^{2}+h^{2}=a g+g h+h a .
$$

Megjegyzés: A diákoknak tetszett a feladat komplex számokkal való megközelítése, ugyanakkor megbeszéltük az alig eltérő analitikus geometriai megközleítésmódot is, majd a két módszer előnyeit, illetve hátrányait mérlegeltük.

4.2.12. Feladat. $A z A B C$ általános háromszög $A B$ oldalára megszerkesztjük az $A B B^{\prime}$ egyenlö oldalú háromszöget, valamint az $A C$ oldalára az $A C C^{\prime}$ egyenlö szárú háromszöget úgy, hogy $m\left(\widehat{A C C^{\prime}}\right)=120^{\circ}$. Bizonyitsd be, hogy ha $M a\left[B^{\prime} C^{\prime}\right]$ felezöpontja, akkor a $B M C$ háromszög derékszögü, és számítsd ki a hegyesszögeinek mértéket!

\section{Kérdések:}

- Mi van megadva és mit kér a feladat?

- Ki tudnád fejezni a származtatott adatokat az elsődleges adatok segítségével? Ki tudnád számítani az $M$ pont affixumát a $B$ és $C$ affixumai segítségével?

- Komplex számok segítségével, hogyan igazolható a legegyszerúbben, hogy egy háromszög derékszögü?

- Tudnál egyúttal az oldalhosszak viszonyára is következtetni? Mit jelent ez? Milyen más lehetőségek vannak?

Megoldás: Minden pont affixumát jelölje a neki megfelelő kisbetű. (4.38. ábra)

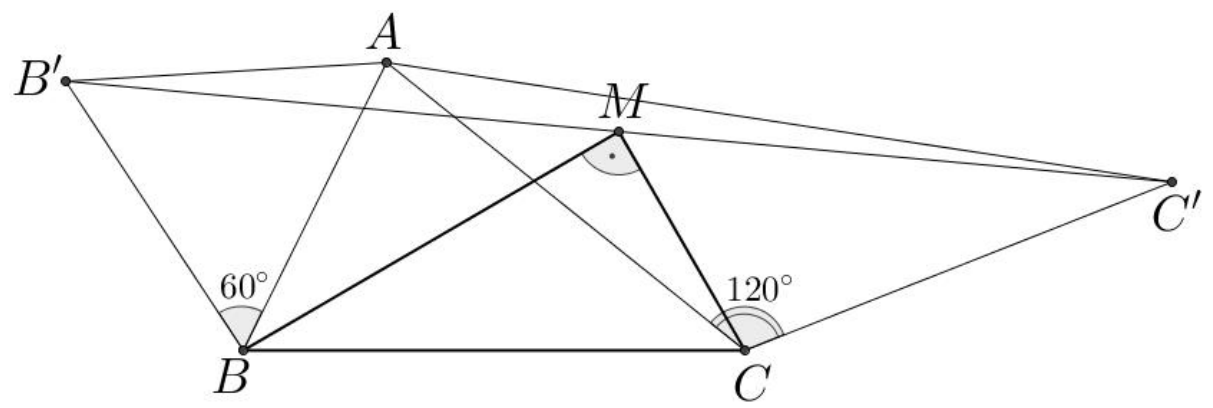

4.38. ábra. Az oldalakra szerkesztett háromszögek

Ekkor

$$
b^{\prime}=(a-b)\left(\frac{1}{2}+i \frac{\sqrt{3}}{2}\right)+b, \quad c^{\prime}=-(a-c)\left(\frac{1}{2}-i \frac{\sqrt{3}}{2}\right)+c
$$




$$
m=\frac{b^{\prime}+c^{\prime}}{2}=\frac{b+c}{2}+\frac{c-b}{2} \cdot\left(\frac{1}{2}+i \frac{\sqrt{3}}{2}\right) .
$$

Sejthető, hogy a $B M C_{\triangle} 30^{\circ}-60^{\circ}$-os derékszögü háromszög. Be kell látnunk tehát, hogy $B M \perp C M$ és $B M=\sqrt{3} \cdot C M$. Mindezek bizonyítása érdekében vizsgáljuk a $\frac{b-m}{c-m}$ törtet, hiszen ennek argumentuma megadja a két oldal által bezárt szöget, míg abszolút értéke éppen a két oldalhossz arányával egyezik meg.

$$
\begin{aligned}
& \frac{b-m}{c-m}=\frac{b-\frac{b+c}{2}-\frac{c-b}{2} \epsilon}{c-\frac{b+c}{2}-\frac{c-b}{2} \epsilon}=\frac{b-c-c \epsilon+b \epsilon}{c-b-c \epsilon+b \epsilon}=\frac{(b-c)(1+\epsilon)}{(b-c)(-1+\epsilon)}= \\
& =\frac{1+\frac{1}{2}+i \frac{\sqrt{3}}{2}}{-1+\frac{1}{2}+i \frac{\sqrt{3}}{2}}=\frac{3+i \sqrt{3}}{-1+i \sqrt{3}}=\frac{-3-i \sqrt{3}-3 i \sqrt{3}+3}{4}=-i \sqrt{3} .
\end{aligned}
$$

Mivel a hányados tiszta imaginárius szám, ezért $B M \perp C M$, és mivel abszolút értéke $\sqrt{3}$, ezért $B M=\sqrt{3} \cdot C M$. Tehát a $B M C_{\triangle}$ valóban derékszögü, melyben $m(\widehat{B})=30^{\circ}$, $m(\widehat{C})=60^{\circ}$.

Megjegyzés: A feladat a diákok egy részének nem okozott különösebb gondot, viszont voltak, akik csak a segítő kérdések mentén tudtak haladni, és a megfelelő forgatások felírásával is problémájuk adódott. Többen felismerték a feladatnak az előtesztből már ismert kalózos problémával való hasonlóságát.

4.2.13. Feladat. Egy négyszög oldalaira kifelé négyzeteket rajzolunk, majd az átellenes négyzetek középpontjait összekötjük. Igazold, hogy e két szakasz merőleges egymásra és egyenlö hosszúságú!

\section{Kérdések:}

- Mi van megadva és mit kér a feladat? Készíts ábrát!

- Fel tudnád írni a négyzetek középpontjainak affixumait csak a négyszög csúcsainak affixumai segítségével?

- Hogyan tudnád a legegyszerübben igazolni, hogy két szakasz azonos hosszúságú és merőleges egymásra?

Megoldás: Legyenek a négyszög csúcsainak affixumai $a, b, c$, illetve $d$, az oldalak fölé szerkesztett négyzetek középpontjaié pedig $x, y, z$ és $v$. Kifejezzük az utóbbiakat az előbbiek függvényében. (4.39. ábra)

Ha az $A B$ oldal fölé szerkesztett négyzet középpontjának affixuma $x$, akkor $X A=X B$ és $X A \perp X B$ miatt

$$
a-x=(b-x) \cdot i
$$

ahonnan

$$
x=\frac{a-b i}{1-i}
$$

és teljesen hasonlóan

$$
y=\frac{b-c i}{1-i}, \quad z=\frac{c-d i}{1-i}, \quad v=\frac{d-a i}{1-i}
$$




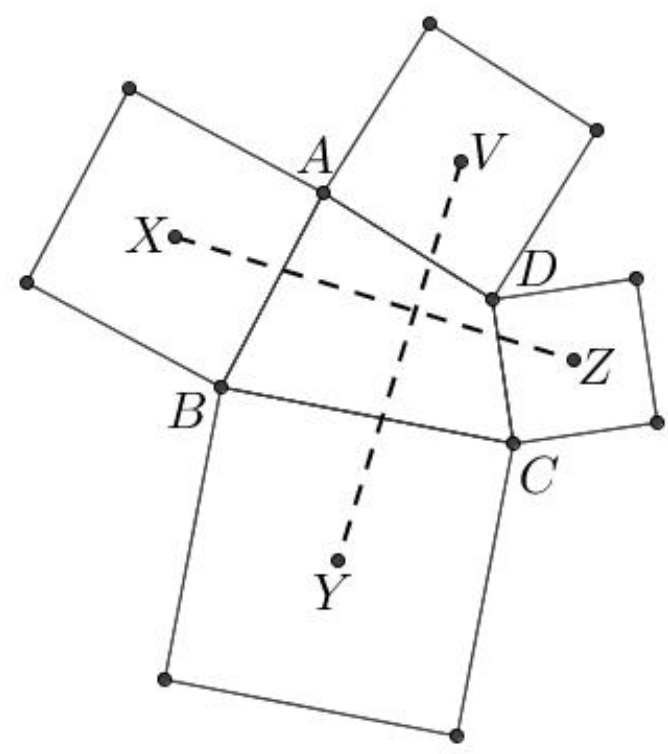

4.39. ábra. Az oldalak fölé rajzolt négyzetek

Annak szükséges és elégséges feltétele, hogy $X Z=Y V$ és $X Z \perp Y V$ az, hogy

$$
(x-z) \cdot i=(y-v) .
$$

Ebbe behelyettesítve az

$$
\begin{aligned}
& x-z=\frac{a-b i}{1-i}-\frac{c-d i}{1-i}=\frac{a-c+d i-b i}{1-i}, \\
& y-v=\frac{b-c i}{1-i}-\frac{d-a i}{1-i}=\frac{b-d+a i-c i}{1-i},
\end{aligned}
$$

összefüggéseket, majd végigszorozva $(1-i)$-vel kapjuk, hogy

$$
(a-c+d i-b i) \cdot i=b-d+a i-c i,
$$

ami igaz, tehát a két szakasz kongruens és merőleges egymásra.

A megoldásból kiderül, hogy az állítás konkáv négyszögek esetén is igaz.

Megjegyzés: Kisebb nehézséget némelyeknek a megoldás legelején, a középpontok affixumainak megfelelő felírása okozott, a további számításokkal viszont már mindenki jól boldogult.

4.2.14. Feladat. Egy $60^{\circ}$-os szög egyik szárán elhelyezkedő A, illetve $A_{1}$ pontoknak a szög csúcsától mért távolsága $p$, illetve $2 q$; a másik száron elhelyezkedö $B$, illetve $B_{1}$ pontoknak a csúcstól mért távolsága pedig q, illetve $2 p$. Az $\left[A_{1} B_{1}\right]$ szakasz felezöpontja $C$. Milyen természetü az $A B C$ háromszög?

\section{Kérdések:}

- Mi van megadva és mit kér a feladat? Készíts ábrát! 
- Ki tudnád számítani a pontok affixumait az adatok segítségével?

- Meg tudnál fogalmazni valamilyen sejtést a keletkező háromszög természetére vonatkozóan?

- Hogyan tudnád bizonyítani ezt? Milyen lehetőségek vannak? Melyik előnyös, melyik kevésbé az?

Megoldás: Az egyszerüség kedvéért legyen a szög csúcsa az origóban, az [OA szára pedig legyen a valós tengely. A másik szár ennek $60^{\circ}$-kal való elforgatottja pozitív trigonometrikus irányba. (4.40. ábra) Ha a forgatás egységét

$$
\epsilon=\frac{1}{2}+i \frac{\sqrt{3}}{2}, \quad \epsilon^{3}=-1
$$

jelöli, akkor

$$
a=p, \quad a_{1}=2 q, \quad b=q \cdot \epsilon, \quad b_{1}=2 p \cdot \epsilon .
$$

Mivel $C$ az $\left[A_{1} B_{1}\right]$ felezőpontja, ezért $c=p \cdot \epsilon+q$.

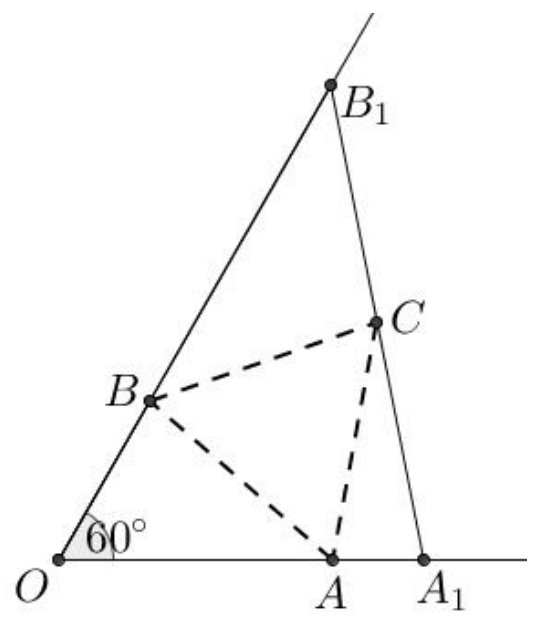

4.40. ábra. A szögtartományban levő háromszög

1. módszer. Az $A B C$ háromszög szabályos, ha például $B$ a $C$ pontnak az $A$ pont körüli $+60^{\circ}$-kal való elforgatottja, azaz

$$
b-a=(c-a) \cdot \epsilon .
$$

A fölírt affixumokat behelyettesítve

$$
\begin{gathered}
q \cdot \epsilon-p=(p \cdot \epsilon+q-p) \cdot \epsilon, \\
p\left(\epsilon^{2}-\epsilon+1\right)=0,
\end{gathered}
$$

ami igaz, mert $\epsilon^{3}=-1$ miatt $\epsilon^{2}-\epsilon+1=0$.

2. módszer. Az affixumok értékét behelyettesítjük a szabályos háromszög csúcsainak affixumaira vonatkozó szükséges és elégséges feltételbe. Ekkor

$$
p^{2}+q^{2} \cdot \epsilon^{2}+p^{2} \cdot \epsilon^{2}+2 p q \cdot \epsilon+q^{2}=
$$




$$
=p q \cdot \epsilon+p q \cdot \epsilon^{2}+q^{2} \cdot \epsilon+p^{2} \cdot \epsilon+p q .
$$

Ezt rendezve kapjuk, hogy

$$
\begin{gathered}
p^{2}\left(\epsilon^{2}-\epsilon+1\right)+q^{2}\left(\epsilon^{2}-\epsilon+1\right)=p q\left(\epsilon^{2}-\epsilon+1\right), \\
\left(p^{2}-p q+q^{2}\right)\left(\epsilon^{2}-\epsilon+1\right)=0,
\end{gathered}
$$

ami igaz, mert $\epsilon^{3}=-1$ miatt $\epsilon^{2}-\epsilon+1=0$.

3. módszer. A feladat szintetikus geometriai eszközökkel is megoldható (4.41. ábra). Mivel $O A_{1}=2 O B=2 q, O B_{1}=2 O A=2 p$ és az $\widehat{O}$ közös szög, ezért O.SZ.O. eset alapján az $O A B_{\triangle} \sim O B_{1} A_{1 \triangle}$, így $A B=\frac{1}{2} A_{1} B_{1}$. Ugyanakkor az $A_{1}$, ill. $B_{1}$ pontokból merőlegeseket bocsátva az $O B_{1}$, ill. $O A_{1}$ egyenesekre, mivel $m(\widehat{O})=60^{\circ}$, ezért $30^{\circ}-60^{\circ}$-os derékszögü háromszögek keletkeznek, és $O A_{1}=2 O B$, ill. $O B_{1}=2 O A$ miatt a merölegesek talppontja éppen az $A$, ill. $B$ pont lesz. Így az $O A_{1} B$ valamint az $O B_{1} A$ derékszögü háromszögekben $B C=\frac{1}{2} A_{1} B_{1}$, ill. $A C=\frac{1}{2} A_{1} B_{1}$. Tehát $A B=B C=A C$, vagyis a háromszög szabályos.

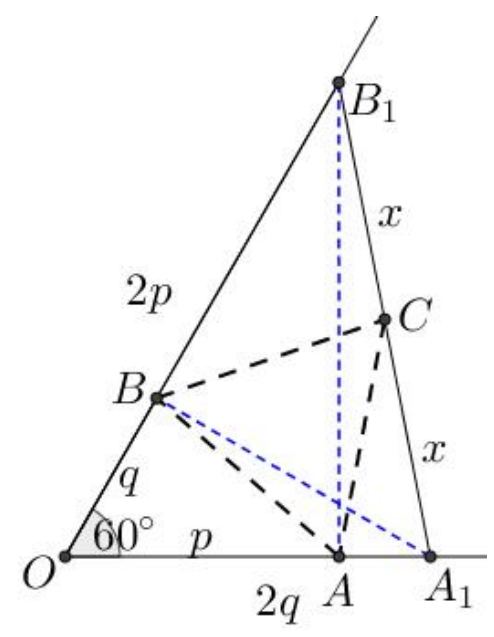

4.41. ábra. Elemi geometriai megoldás

Megjegyzés: A feladattal önállóan boldogultak a diákok, és a háromszög szabályosságának mindkét módon való igazolása előfordult a megoldásokban. Akik nem teljesen biztosak a forgatások felírásában, inkább a 2. módszert, az azonosságba való behelyettesítést részesítik előnyben.

4.2.15. Feladat. Legyen $P$ az $A B C$ háromszögnek egy olyan belső pontja, amelyre $m(\widehat{P A C})=m(\widehat{P B C})$. Jelölje $K$ és $L$ a $P$ pontnak az $A C$, illetve $B C$ oldalakra esö merőleges vetületét, és legyen $D$ az $[A B]$ felezöpontja. Igazold, hogy $D K=D L$.

\section{Kérdések:}

- Mi van megadva és mit kér a feladat? Készíts ábrát!

- A számítások egyszerüsítése érdekében, hogyan érdemes elhelyezni a háromszöget a komplex számsíkban? 
- Ki tudnád fejezni a szerkesztett pontok affixumait az elsődleges adatok segítségével?

- Hogyan használnád fel, hogy két szög kongruens? Hát hogy merőleges vetületekről van szó?

- Fel tudnád írni a $K$ és $L$ affixumát csak a $P$ pont affixuma és a kongruens szögek segítségével?

- Hogyan tudnád kimutatni a szakaszhosszak egyenlőségét?

Megoldás: Mivel a $C$ pont helyzete nem lényeges, helyezzük el a háromszöget a komplex számsíkon úgy, hogy az $[A B]$ oldal $D$ felezőpontja az origóba kerüljön. Ekkor $d=0$ és $b=-a$. (4.42. ábra)

Kifejezzük a $K$ és $L$ pontok affixumát a $P$ és $A$ pontok $p$, ill. a affixuma segítségével, majd megpróbáljuk igazolni, hogy $|k|=|l|$, ami éppen a kért egyenlőséget jelenti.

Legyen $m(\widehat{P A K})=m(\widehat{P B L})=\alpha$. Mivel $P K \perp A K$ és $P L \perp B L$, ezért

$$
\begin{gathered}
p-k=i(a-k) \operatorname{tg} \alpha, \\
p-l=i(b-l) \operatorname{tg} \alpha=i(-a-l) \operatorname{tg} \alpha .
\end{gathered}
$$

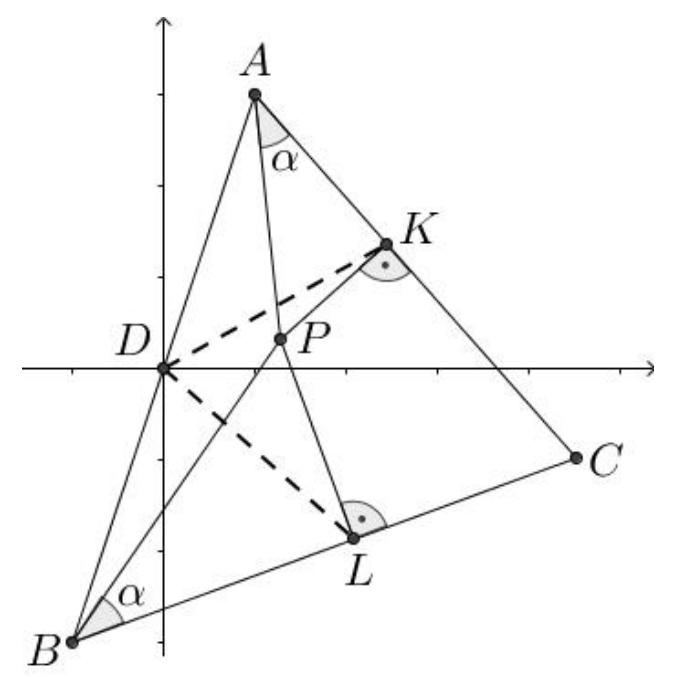

4.42. ábra.

Kifejezve $k$-t és $l$-et

$$
k=\frac{p-a i \operatorname{tg} \alpha}{1-i \operatorname{tg} \alpha}, \quad l=\frac{p+a i \operatorname{tg} \alpha}{1-i \operatorname{tg} \alpha},
$$

ahonnan nyilvánvaló, hogy $k \cdot \bar{k}=l \cdot \bar{l}$, ami azt jelenti, hogy $|k|^{2}=|l|^{2}$, vagyis $D K=D L$.

Megjegyzés: A feladat önálló munkára nehéznek bizonyult, így a kérdések mentén haladva együtt oldottuk meg azt.

4.2.16. Feladat. $A z A B C$ háromszögben jelölje $m_{a}$ az $A$ csúcshoz tartozó magasság, $s_{a}$ az A csúcshoz tartozó súlyvonal hosszát, valamint $R$ és $r$ a háromszög köré-, illetve beírt körének sugarát. Igazold, hogy $\frac{R}{2 r} \geq \frac{s_{a}}{m_{a}}$. 


\section{Kérdések:}

- Milyen összefüggéseket ismersz a háromszög beírt és köréírt körének sugarára?

- Hogyan tudnád becsülni egy oldal és a hozzá tartozó súlyvonal hosszának szorzatát? Mikor áll fenn egyenlöség?

- Át tudnád úgy alakítani az egyenlőtlenséget, hogy csak a komplex számokkal könnyen felírható adatok maradjanak benne?

Megoldás: A háromszög területét jelölje $T$, kerületét pedig $K$. (4.43. ábra) Ekkor

$$
\frac{R}{2 r} \geq \frac{s_{a}}{m_{a}} \Longleftrightarrow 2 r s_{a} \leq R m_{a} \Longleftrightarrow 2 \frac{2 T}{K} s_{a} \leq R \frac{2 T}{B C} \quad \Longleftrightarrow \quad 2 B C s_{a} \leq R \cdot K .
$$

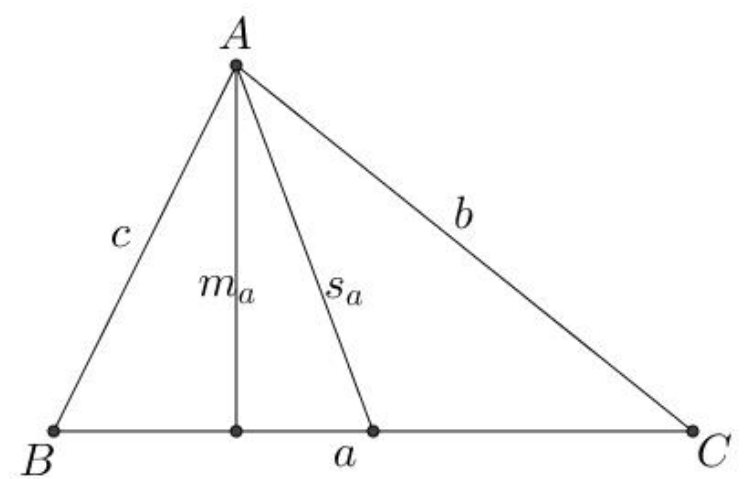

4.43. ábra.

Az $A, B, C$ csúcspontok affixumait rendre $a, b, c$-vel jelölve kapjuk, hogy

$$
\begin{aligned}
& 2 B C s_{a}=2|b-c|\left|a-\frac{b+c}{2}\right|=|b-c||2 a-b-c|=|(b-c)(2 a-b-c)|= \\
= & |a(b-c)+b(a-b)+c(c-a)| \leq|a||b-c|+|b||a-b|+|c||c-a|=R \cdot K,
\end{aligned}
$$

hiszen $|a|=|b|=|c|=R$. Egyenlőség szabályos háromszög esetén áll fenn.

Megjegyzés: A feladat a diákok számára nehéz volt, így együtt oldottuk meg.

\section{Házi feladatok}

4.2.17. Feladat. Egy szabályos háromszög egyik csúcsa az $A(2 \sqrt{3} ; 2 \sqrt{3})$ koordinátájú pont. A háromszög súlypontja az origó. Határozd meg a többi csúcs koordinátáit!

Megoldás. Origó körüli $120^{\circ}$-os pozitív, illetve negatív irányú forgatással kiszámíthatók a másik két csúcs koordinátái.

Legyen a megadott $A$ pont affixuma $a=2 \sqrt{3}+i 2 \sqrt{3}$. Ekkor a $B$ pont affixuma

$$
b=a \cdot\left(\cos \frac{2 \pi}{3}+i \sin \frac{2 \pi}{3}\right)=(2 \sqrt{3}+i 2 \sqrt{3}) \cdot\left(-\frac{1}{2}+i \frac{\sqrt{3}}{2}\right)=-3-\sqrt{3}+i(3-\sqrt{3}),
$$


vagyis $B(-3-\sqrt{3} ; 3-\sqrt{3})$. Hasonlóan a $C$ pont affixuma

$c=a \cdot\left(-\cos \frac{2 \pi}{3}-i \sin \frac{2 \pi}{3}\right)=(2 \sqrt{3}+i 2 \sqrt{3}) \cdot\left(-\frac{1}{2}-i \frac{\sqrt{3}}{2}\right)=3-\sqrt{3}+i(-\sqrt{3}-3)$,

tehát $C(3-\sqrt{3} ;-3-\sqrt{3})$.

Megjegyzés. Mivel $A(2 \sqrt{3} ; 2 \sqrt{3})$ is és a háromszög súlypontja is rajta van az első szögfelezőn, ezért a háromszög egyik szimmetriatengelye éppen az első szögfelező, így $B$ és $C$ szimmetrikusak erre nézve, tehát $C$ koordinátái azonnal adódnak $B$ koordinátáinak felcserélésével, így tulajdonképpen elég csak az egyik pont koordinátáit kiszámítani.

4.2.18. Feladat. $A z A B C$ általános háromszög $A B$ és $A C$ oldalaira megszerkesztjük az $A B B^{\prime}$ illetve $A C C^{\prime}$ egyenlő szárú derékszögü háromszögeket, úgy hogy $m\left(\widehat{A B B^{\prime}}\right)=$ $m\left(\widehat{A C C^{\prime}}\right)=90^{\circ}$. Mutasd ki, hogy ha $M$ a $\left[B^{\prime} C^{\prime}\right]$ felezöpontja, akkor a BMC háromszög is egyenlö szárú és derékszögü!

Megoldás. Minden pont affixumát jelölje a neki megfelelő kisbetű. (4.44. ábra)

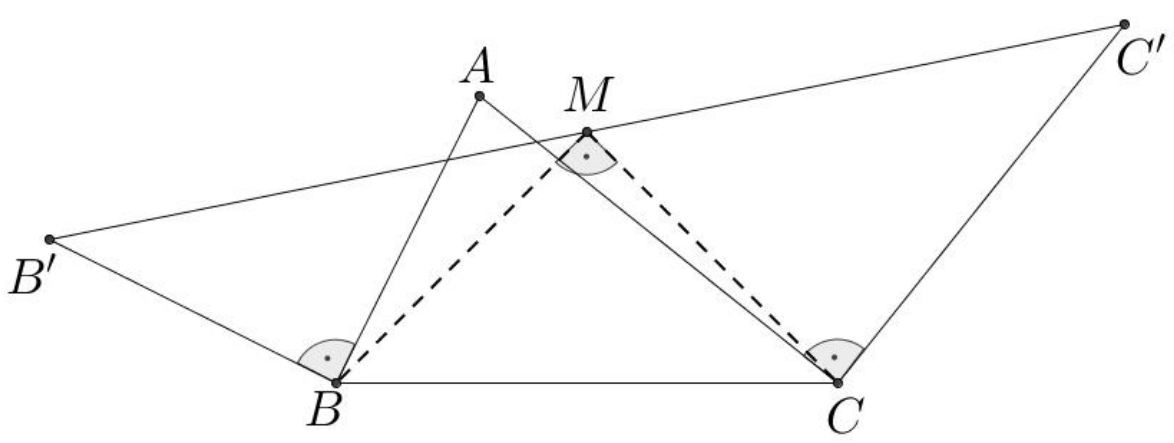

4.44. ábra. Az oldalakra szerkesztett derékszögü háromszögek

Ekkor

$$
b^{\prime}=(a-b) i+b, \quad \text { illetve } \quad c^{\prime}=-(a-c) i+c,
$$

így

$$
m=\frac{b^{\prime}+c^{\prime}}{2}=\frac{a i-b i+b-a i+c i+c}{2}=\frac{b+c+c i-b i}{2}
$$

A $B M C$ háromszög pontosan akkor egyenlő szárú és derékszögü, ha

$$
c-m=(b-m) i \quad \Longleftrightarrow \quad m=\frac{c-b i}{1-i} .
$$

Bővítve a törtet a nevező konjukáltjával

$$
m=\frac{(c-b i)(1+i)}{(1-i)(1+i)}=\frac{c+c i-b i+b}{2},
$$

ami igaz, tehát a háromszög egyenlő szárú és derékszögü. 
4.2.19. Feladat. $A z A B C$ tetszőleges háromszög oldalaira kifele szerkesszük meg rendre az ABK, BCI, CAJ egyenlő oldalú háromszögeket. Bizonyítsd be a következö állításokat!

a) $A z A B C$ és IJK háromszög súlypontja egybeesik. Jelöljük ezt G-vel.

b) A BCI,CAJ, ABK egyenlö oldalú háromszögek $U, V$, illetve $W$ súlypontjai szintén egyenlö oldalú háromszöget alkotnak, melynek súlypontja $G$.

Megoldás. Legyen $\epsilon=\frac{1}{2}+i \frac{\sqrt{3}}{2}$, ahol $\epsilon^{3}=-1$. (4.45. ábra)

a) Ekkor

$$
i=(b-c) \epsilon+c, \quad j=(c-a) \epsilon+a, \quad k=(a-b) \epsilon+b,
$$

amiket összeadva kapjuk, hogy

$$
i+j+k=a+b+c,
$$

vagyis az $A B C$ és $I J K$ háromszögek súlypontja egybeesik, melyet jelöljünk $G$-vel.

b) A $B C I, C A J, A B K$ egyenlő oldalú háromszögek $U, V$, illetve $W$ súlypontjainak affixumai

$$
u=\frac{b+c+i}{3}, \quad v=\frac{a+j+c}{3}, \quad w=\frac{a+b+k}{3} .
$$

Összeadva

$$
u+v+w=\frac{2 a+2 b+2 c+i+j+k}{3}=a+b+c,
$$

tehát az $U V W$ háromszög súlypontja is $G$.

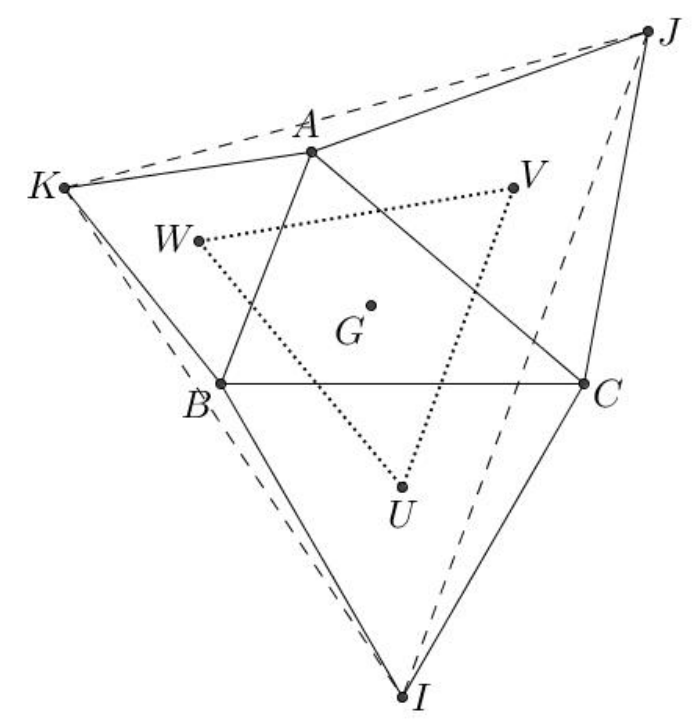

4.45. ábra. Az oldalakra szerkesztett szabályos háromszögek

Még bizonyítanunk kell, hogy $U V W$ egyenlő oldalú. Ez pontosan akkor áll fenn, ha

$$
w=(v-u) \epsilon+u .
$$

Behelyettesítve, és beszorozva 3-mal

$$
a+b+k=(a+j-b-i) \epsilon+b+c+i
$$


amibe szintén behelyettesítve, majd rendezve, kapjuk, hogy

$$
(2 c-a-b)\left(\epsilon^{2}-\epsilon+1\right)=0,
$$

ami igaz, mert $\epsilon^{3}=-1$ miatt $\epsilon^{2}-\epsilon+1=0$. Tehát az $U V W_{\triangle}$ valóban egyenlő oldalú.

4.2.20. Feladat. $A z A B C$ háromszög oldalaira kifele négyzeteket rajzolunk, ezek az $A I H B, B E D C$ és CGFA; a GCDQ és EBHP négyszögek pedig paralelogrammák. Bizonyitsd be, hogy az APQ háromszög derékszögü és egyenlö szárú!

Megoldás. Annak szükséges és elégséges feltétele, hogy az $A P Q$ háromszög derékszögű és egyenlő szárú legyen az, hogy a $Q$ pont a $P$ pontnak $A$ körüli $+90^{\circ}$-kal való elforgatottja legyen (4.46. ábra), vagyis teljesüljön, hogy

$$
q=(p-a) \cdot i+a .
$$

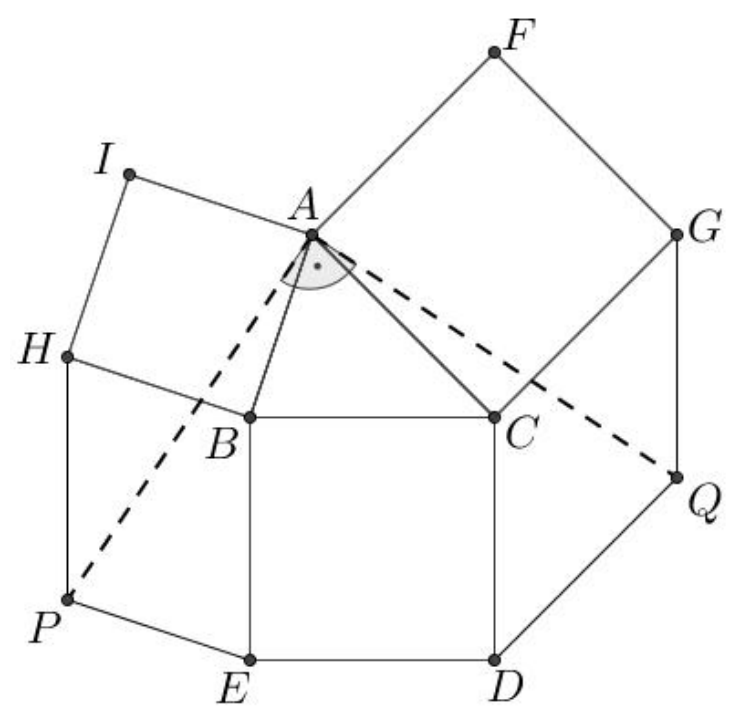

4.46. ábra. Az oldalak fölé rajzolt négyzetek

Ennek igazolása érdekében kifejezzük a $P$ és $Q$ pontok $p$, ill. $q$ affixumát az $a, b, c$ függvényében.

Mivel $G C D Q$ és $E B H P$ négyszögek paralelogrammák, ezért

$$
c+q=d+g, \quad \text { illetve } \quad b+p=h+e,
$$

ahonnan

$$
q=d+g-c, \quad \text { illetve } \quad p=h+e-b .
$$

Ugyanakkor, mivel $B E D C$ és $C G F A$ négyzet, ezért

$$
d=(b-c) \cdot i+c, \quad g=-(a-c) \cdot i+c,
$$

tehát

$$
q=-a \cdot i+b \cdot i+c .
$$


Hasonlóan, mivel $A I H B$ és $B E D C$ négyzet, ezért

$$
h=(a-b) \cdot i+b, \quad e=-(c-b) \cdot i+b,
$$

így

$$
p=b+a \cdot i-c \cdot i .
$$

Behelyettesítve a $q=(p-a) \cdot i+a$ összefüggésbe

$$
-a \cdot i+b \cdot i+c=(b+a \cdot i-c \cdot i-a) \cdot i+a,
$$

ami igaz, tehát az $A P Q$ háromszög derékszögü és egyenlö szárú.

4.2.21. Feladat. Egy ABC háromszög oldalai fölé szerkesztett négyzetek középpontjai szabályos háromszöget alkotnak. Mit mondhatunk az ABC háromszögröl?

Megoldás. Legyenek a háromszög csúcsainak affixumai $a, b$, illetve $c$, az oldalak fölé szerkesztett négyzetek középpontjaié pedig $x, y$ és $z$. (4.47. ábra) Meghatározzuk az utóbbiakat az előbbiek függvényében, majd felhasználva, hogy $X Y Z_{\triangle}$ egyenlő oldalú, következtetünk az $A B C$ háromszög természetére.

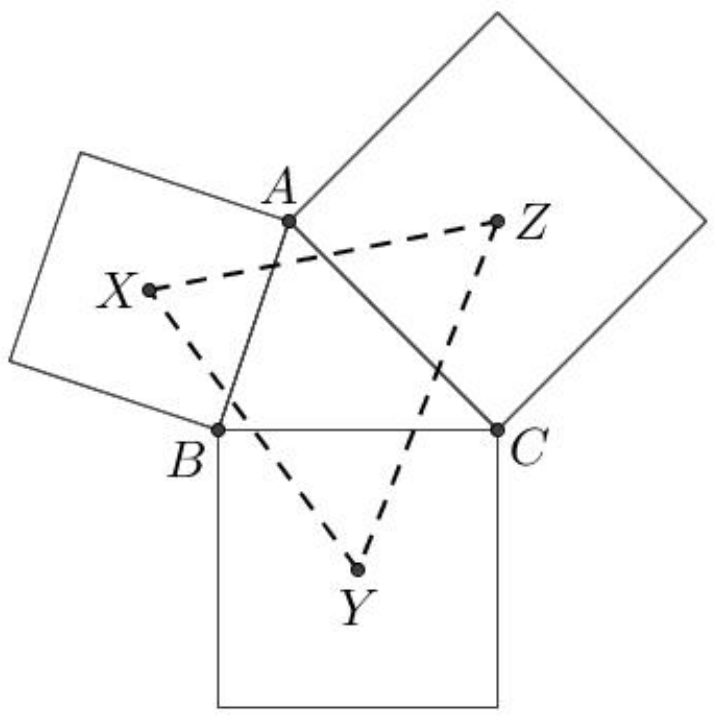

4.47. ábra. Az oldalak fölé rajzolt négyzetek

Ha az $A B$ oldal fölé szerkesztett négyzet középpontjának affixuma $x$, akkor $X A=X B$ és $X A \perp X B$ miatt

$$
(x-a) i=b-x,
$$

ahonnan

$$
x=\frac{b+a i}{1+i},
$$

és teljesen hasonlóan

$$
y=\frac{c+b i}{1+i}, \quad z=\frac{a+c i}{1+i}
$$


Mivel $X Y Z$ háromszög szabályos, ezért

$$
x^{2}+y^{2}+z^{2}=x y+y z+z x .
$$

Ebbe behelyettesítve, majd $(1+i)^{2}$-nel beszorozva az összefüggést kapjuk, hogy

$$
\begin{gathered}
b^{2}+2 a b i-a^{2}+c^{2}+2 b c i-b^{2}+a^{2}+2 a c i-c^{2}= \\
=b c+b^{2} i+c a i-a b+a c+c^{2} i+a b i-b c+a b+a^{2} i+b c i-c a .
\end{gathered}
$$

Összevonva a tagokat, és végigosztva $i$-vel az

$$
a^{2}+b^{2}+c^{2}=a b+b c+c a
$$

összefüggéshez jutunk, ami éppen azt jelenti, hogy az $A B C$ háromszög szabályos. Mivel az egyik egyenlőségtől a másikhoz ekvivalens lépések által jutottunk, állíthatjuk, hogy az oldalak fölé írt négyzetközéppontok által meghatározott háromszög pontosan akkor szabályos, ha az eredeti háromszög is az. 


\subsection{Alkalmas függvény keresése}

A harmadik stratégia bizonyos problémák megoldását jelentősen elősegítő alkalmas függvény megtalálását és annak valamilyen tulajdonságának felhasználását kívánta. Nagyrészt egyenletek, egyenlötlenségek és egyenletrendszerek nem algoritmikus megoldásával, illetve különböző geometriai szélsőértékek keresésével szemléltettem ezt. Célom ennek a stratégiának a bemutatásával annak tudatosítása volt a diákokban, hogy a romániai középiskolai tananyag központi elemének számító függvény fogalma és az arra épülő matematikai analízis nem elszigetelt tudományterület, hanem egy lehetséges és gyakran nagyon hasznos eszköz az problémamegoldás során. Lássák a diákok, hogy a matematika különböző területeinek az összekapcsolása hasznos és sok esetben nélkülözhetetlen a nem sablonszerü problémák eredményes megoldása érdekében.

\subsubsection{Elemi függvények tulajdonságainak felhasználása}

Az elemi függvények és azok tulajdonságainak vizsgálata 9-10. osztályos tananyag Romániában. Ugyancsak ebben a két évben a romániai matematika-tanterv viszonylag sok időt szán az elemi függvényekhez kapcsolódó tipikus egyenletek, egyenlőtlenségek és egyenletrendszerek megoldására. Ám a sokféle algoritmikus megoldási eljárás mégiscsak egy eléggé szűk, sajátosan ezekre a módszerekre szabott egyenletek megoldására alkalmas. Gyakori kérdése a diákoknak, hogy hogyan boldogulunk olyan esetekben, amikor a megoldásra váró egyenlet nem annyira „szépen” elóállított. A valamivel általánosabb módszerek, eljárások, stratégiák tanítására már kevesebb idő jut, holott az azokhoz szükséges eszközök gyakran a diákok rendelkezésére állnak, csak tudniuk kellene, hogy mikor mire érdemes használni azokat. Jobb esetben a diákok kitalálják az adott egyenlet megoldását, de az unicitás bizonyítását illetően már ötlettelenek.

Néhány ilyen egyenlet, egyenlőtlenség, illetve rendszer megoldására vonatkozó eljárás:

- értelmezési tartomány, értékkészlet vizsgálata

- függvény injektivitásának (egy-egy értelmüségének) felhasználása

- függvény szigorúan monoton tulajdonságának felhasználása

- függvény szigorúan konvex/konkáv voltának felhasználása

- áttérés függvények egyenlőségéről az inverzeik egyenlőségére

- szigorúan növekvő függvény és inverzének egyenlősége

Tapasztalataim szerint még rosszabb a helyzet a különböző algebrai, de főleg geometriai szélsőérték-problémák megoldása tekintetében, hiszen a diákoknak nagy nehézséget okoz a megfelelő elemi becslések megtalálása. Ha már semmilyen elemi módszer sem segít, gyakran valamilyen alkalmas függvény korlátossága, szélsőértékeinek kiszámítása vezet el a kívánt összefüggéshez. 


\section{Órán megoldott feladatok}

4.3.1. Feladat. Oldd meg a $\sqrt{x+1}+\sqrt{1-x^{2}}=\sqrt[3]{x^{2}+7}-2$ egyenletet!

\section{Kérdések:}

- Milyen halmazon értelmezettek az egyenletben szereplő kifejezések?

- Mennyi lehet ekkor a gyökkifejezések értéke? Hát a két oldalé?

- Milyen következtetés vonható le a két oldal értékkészletének összevetéséből?

Megoldás: A bal oldalon megjelenő kifejezések értelmezéséhez szükséges, hogy $x \in$ $[-1,1]$ legyen. Ha ez teljesül, akkor viszont $x^{2}+7 \leq 8$ és így $\sqrt[3]{x^{2}+7}-2 \leq 0$. Ugyanakkor $\sqrt{x+1}+\sqrt{1-x^{2}} \geq 0$, tehát egyenlöség csak akkor teljesülhet, ha mindkét oldal nulla. Ez csak $x=-1$ esetén következik be, tehát $x=-1$ az egyetlen megoldás.

Megjegyzés: Ez a bemelegítőnek szánt feladat teljes sikert aratott. Bár voltak, akik első ránézésre megpróbálták valamilyen hatványra emelni az egyenlet két oldalát, de hamar rájöttek, hogy ez reménytelen és szerencsére szükségtelen is, majd az értékkészleteket tanulmányozva rájöttek a megoldásra.

4.3.2. Feladat. Oldd meg a valós számok halmazán az alábbi egyenleteket!

$$
\begin{array}{ll}
\text { a) } \sqrt{x}=x^{2}-3 x+1+|x-1| & \text { b) } 2^{\sin ^{2} x}-2^{\cos ^{2} x}=\cos 2 x
\end{array}
$$

\section{Kérdések:}

- Milyen halmazon értelmezett az egyenlet?

- Ki tudnál alakítani hasonló alakú kifejezéseket az egyenlet két oldalán?

- Hogyan írható át másként az abszolút érték? Miből származhat esetleg? Hogyan alakítható át a $\cos 2 x$ ?

- Mi az egyenlet két oldalának szerkezetileg azonos alakja?

- Ha sikerült kialakítani két teljesen hasonló szerkezetü kifejezést az egyenlet két oldalán, mire tudnál ebből következtetni? Mi miatt állítható ez?

- Meg tudnád oldani a kapott egyszerübb egyenletet?

Megoldás: a) Az egyenlet a $[0, \infty)$ intervallumon értelmezett, és átírható az

$$
x+\sqrt{x}=(x-1)^{2}+\sqrt{(x-1)^{2}}
$$

alakba. Mivel az egyenlet két oldala szerkezetileg azonos, tekintsük az

$$
f:[0, \infty) \rightarrow[0, \infty), \quad f(x)=x+\sqrt{x}
$$

szigorúan monoton, tehát injektív függvényt. Ekkor az egyenlet

$$
f(x)=f\left((x-1)^{2}\right)
$$


alakba írható, ahonnan az

$$
x=(x-1)^{2} \Longleftrightarrow x^{2}-3 x+1=0
$$

egyenlethez jutunk, amelynek megoldásai $x_{1,2}=\frac{3 \pm \sqrt{5}}{2}$, és ezek pozitívak lévén, egyben az eredeti egyenlet megoldásai is. Tehát

$$
M=\left\{\frac{3-\sqrt{5}}{2}, \frac{3+\sqrt{5}}{2}\right\} .
$$

b) Az egyenlet a teljes $\mathbb{R}$-en értelmezett, és $\cos 2 x=\cos ^{2} x-\sin ^{2} x$ miatt

$$
2^{\sin ^{2} x}+\sin ^{2} x=2^{\cos ^{2} x}+\cos ^{2} x
$$

alakba hozható. Mivel az

$$
f: \mathbb{R} \rightarrow \mathbb{R}, \quad f(x)=2^{x}+x
$$

függvény szigorúan növekvő, így injektív, ezért az egyenlet

$$
f\left(\sin ^{2} x\right)=f\left(\cos ^{2} x\right)
$$

alakjából következik, hogy

$$
\sin ^{2} x=\cos ^{2} x \quad \Longleftrightarrow \quad \cos 2 x=0,
$$

aminek megoldásai egyben az eredeti egyenletet is kielégítik, így $M=\left\{ \pm \frac{\pi}{4}+k \pi \mid k \in \mathbb{Z}\right\}$.

Megjegyzés: Főleg az első egyenlet megoldása során az azonos szerkezetű két oldal kialakítása ment nehezebben, az utána következő számítások már nem okoztak gondot. Fontos viszont kihangsúlyozni az injektivitást, mert a diákok többsége csupán formálisan tekintve az egyenletre, hajlamos átsiklani e tulajdonság szükségessége fölött és minden kétely nélkül következtetni az argumentumok egyenlőségére.

4.3.3. Feladat. Oldd meg a $\left\{\begin{array}{l}\sqrt{x}-\sqrt{y}=\log _{3} \frac{y}{x} \\ 2^{x+2}+8^{x}=5 \cdot 4^{y}\end{array} \quad\right.$ egyenletrendszert!

\section{Kérdések:}

- Milyen halmazon értelmezett az egyenlet?

- Át tudnád alakítani az első egyenlet két oldalát ugyanolyan szerkezetűvé?

- Az átírás után mire lehet következtetni? Miért jó ez?

- Fel tudnád ezt használni a másik egyenlet megoldása során?

Megoldás: Az első egyenletben szereplő gyökök és logaritmus miatt $x, y>0$.

$$
\sqrt{x}-\sqrt{y}=\log _{3} \frac{y}{x} \Longleftrightarrow \sqrt{x}+\log _{3} x=\sqrt{y}+\log _{3} y
$$

Mivel az

$$
f: \mathbb{R}_{+} \rightarrow \mathbb{R}, f(t)=\sqrt{t}+\log _{3} t
$$


függvény szigorúan növekvő, ezért injektív, így az egyenletből következik, hogy $x=y$. Ezt felhasználva a rendszer második egyenlete:

$$
2^{x+2}+2^{3 x}=5 \cdot 2^{2 x} \stackrel{2^{x} \neq 0}{\Longrightarrow} 2^{2 x}-5 \cdot 2^{x}+4=0,
$$

ahonnan $2^{x}=1$, azaz $x_{1}=0$, vagy $2^{x}=4$, így $x_{2}=2$. De $x>0$, így az egyenletrendszer megoldáshalmaza $M=\{(2,2)\}$.

Megjegyzés: A feladat a diákok többségének nem okozott nehézséget, így önállóan ki tudták vitelezni a helyes megoldást.

4.3.4. Feladat. Oldd meg az alábbi egyenleteket!

a) $\sqrt{x^{2}-36}+\sqrt{x^{2}-64}+\sqrt{x^{2}-100}=14$

b) $x^{2}-2 x+2=\sqrt{x+7}-\sqrt{x-1}$

\section{Kérdések:}

- Milyen halmazon értelmezett az egyenlet?

- Milyen a bal oldal monotonitása? Hát a jobbé?

- Mire tudnál következtetni ebből?

- Ki tudnád találni a megoldást? Van-e más?

Megoldás: a) Az egyenlet értelmezési tartománya $D=(-\infty,-10] \cup[10, \infty)$. Mivel az

$$
f: D \rightarrow \mathbb{R}, \quad f(x)=\sqrt{x^{2}-36}+\sqrt{x^{2}-64}+\sqrt{x^{2}-100}
$$

függvény szigorúan növekvő a $[10, \infty)$ intervallumon, és a jobb oldal állandó, ezért ebben a halmazban az egyenletnek legfennebb egy megoldása van, és ez az $x=10$. Ugyanakkor mivel $f$ páros függvény, ezért $x=-10$ is megoldás. Tehát $M=\{-10,10\}$.

b) Az egyenlet a $D=[1, \infty)$ intervallumon értelmezett, és mivel az

$$
f: D \rightarrow \mathbb{R}, \quad f(x)=x^{2}-2 x+2
$$

függvény szigorúan növekvő, míg a

$$
g: D \rightarrow \mathbb{R}, \quad g(x)=\sqrt{x+7}-\sqrt{x-1}=\frac{8}{\sqrt{x+7}+\sqrt{x-1}}
$$

függvény szigorúan csökkenő, ezért az $f(x)=g(x)$ egyenletnek legtöbb egy megoldása lehet, és ez az $x=2$. Tehát $M=\{2\}$.

Megjegyzés: A feladat inkább figyelmet és leleményességet igényel, mintsem bonyolult számításokat. Az első egyenletnél noha látták az értelmezési tartomány szimmetriáját, nagyon sokan csak a pozitív megoldást adták meg. Minden bizonnyal az értelmezett függvény páros volta nem fordult meg a fejükben. A második egyenlet esetén a jobb oldal átalakítási technikája nem volt kézenfekvő mindenkinek, így emiatt kellett besegíteni. Mindezektől függetlenül, a diákoknak - elmondásaik szerint - tetszenek a függvénytani tulajdonságokon alapuló egyenletmegoldási módszerek. 
4.3.5. Feladat. Határozd meg azt az $x$ pozitív egész számot, amelyre

$$
\frac{1^{4}}{x}+\frac{2^{4}}{x+1}+\frac{3^{4}}{x+2}+\ldots+\frac{n^{4}}{x+(n-1)}=\frac{n^{2}(n+1)^{2}}{4}, \quad \forall n \in \mathbb{N}^{*} .
$$

\section{Kérdések:}

- Mire emlékeztet az egyenlet jobb oldala?

- A bal oldalnak milyen köze van ehhez?

- Ki tudnál találni egy megoldást? Lehet-e más is?

- Mivel tudnád indokolni az állításodat?

Megoldás: Mivel a jobb oldal az első $n$ természetes szám köbösszegének zárt alakja, ezért olyan $x$ természetes számot kell találni, amelyre a bal oldal a köbszámok sorozatának összege. Ha minden tört nevezője a számlálójában levő hatvány alapja lenne, akkor ez éppen előállna. Ez $x=1$ esetén igaz, hiszen

$$
f(1)=1^{3}+2^{3}+3^{3}+\ldots+n^{3}=\frac{n^{2}(n+1)^{2}}{4} .
$$

Megpróbáljuk igazolni, hogy más megoldás nincs.

Mivel az

$$
f: \mathbb{N}^{*} \rightarrow \mathbb{Q}_{+}, \quad f(x)=\frac{1^{4}}{x}+\frac{2^{4}}{x+1}+\frac{3^{4}}{x+2}+\ldots+\frac{n^{4}}{x+(n-1)}
$$

függvény (sorozat) rögzített $n \in \mathbb{N}^{*}$ esetén szigorúan csökkenő, ezért legfennebb egy olyan érték van, amelyre $f(x)=\frac{n^{2}(n+1)^{2}}{4}$, és ez az $x=1$. Tehát $M=\{1\}$.

Megjegyzés: A jobb oldal felismerése után, az egyenlet megoldását a diákok viszonylag hamar kitalálták. Az unicitás bizonyítása viszont már nem ment annyira egyszerüen.

4.3.6. Feladat. Oldd meg az $2 \cdot x^{\log _{2} 3}-11 \cdot \log _{2} x=4-2 x$ egyenletet!

\section{Kérdések:}

- Milyen értékekre értelmesek az egyenletben szereplő kifejezések?

- Ki tudnád találni a megoldást, esetleg megoldásokat?

- Milyen függvénytani módszerrel tudnád bizonyítani, hogy csak ezek vannak?

- Ki tudnád alakítani a bal oldalra egy konvex függvényt leképezési törvényét? Hát a jobb oldalra egy elsőfokút? Mire lehet ebből következtetni? 
Megoldás: Az egyenlet a $(0, \infty)$ intervallumon értelmezett. Némi próbálkozás után észrevehető, hogy $x=1$ és $x=4$ megoldásai az egyenletnek, és megpróbáljuk igazolni, hogy más nincs.

Felhasználva az $x^{\log _{2} 3}=3^{\log _{2} x}$ azonosságot, az egyenlet

$$
2 \cdot 3^{\log _{2} x}-11 \cdot \log _{2} x=4-2 x
$$

alakba írható. Elvégezve a

$$
t:=\log _{2} x \quad \Longleftrightarrow \quad 2^{t}=x
$$

helyettesítést kapjuk, hogy

$$
2 \cdot 3^{t}-11 t=4-2 \cdot 2^{t} \Longleftrightarrow 2\left(3^{t}+2^{t}\right)=11 t+2 .
$$

Mivel az egyenlet a bal oldala szigorúan konvex, a jobb oldala pedig elsőfokú, így legtöbb két megoldása lehet, és ezek $t=0$ és $t=2$, ahonnan az eredeti egyenlet megoldáshalmaza $M=\{1 ; 4\}$.

Megjegyzés: Némi próbálkozás után az egyenlet megoldásait a diákok viszonylag hamar kitalálták, viszont az egyenlet célszerü átalakítása az unicitás bizonyítása érdekében már nem ment önállóan, így azt együtt végeztük el.

4.3.7. Feladat. Oldd meg a $\log _{3}\left(2^{x}+1\right)=\log _{2}\left(3^{x}-1\right)$ egyenletet!

\section{Kérdések:}

- Milyen értékekre értelmesek az egyenletben szereplő kifejezések?

- Ki tudnád találni a megoldást?

- Milyen függvénytani módszerekkel lehet bizonyítani ennek egyetlenségét?

- Hogyan fejezhető ki az ismeretlen a bal, ill. a jobb oldali kifejezésből?

- Ki tudnál alakítani egy olyan egyenletet, amelynek két oldala ugyanolyan szerkezetü? Mire lehet ebből következtetni?

- Meg tudnád oldani a kapott egyismeretlenes egyenletet?

Megoldás: Az egyenlet a $(0, \infty)$ intervallumon értelmezett, és az

$$
y=\log _{3}\left(2^{x}+1\right)=\log _{2}\left(3^{x}-1\right)
$$

egyenlőségből következik, hogy

$$
2^{x}+1=3^{y}, \quad \text { illetve } \quad 3^{x}-1=2^{y} .
$$

Ezeket összeadva a

$$
2^{x}+3^{x}=2^{y}+3^{y}
$$

egyenlethez jutunk. Mivel az

$$
f: \mathbb{R} \rightarrow(0, \infty), \quad f(x)=2^{x}+3^{x}
$$


függvény szigorúan növekvő $\mathbb{R}$-en, ezért injektív, ahonnan következik, hogy $x=y$. Ezt figyelembe véve az egyenlet

$$
2^{x}+1=3^{x} \Longleftrightarrow\left(\frac{2}{3}\right)^{x}+\left(\frac{1}{3}\right)^{x}=1
$$

alakba írható. Mivel a

$$
g: \mathbb{R} \rightarrow(0, \infty), \quad g(x)=\left(\frac{2}{3}\right)^{x}+\left(\frac{1}{3}\right)^{x}
$$

függvény szigorúan csökkenő, és az egyenlet jobb oldala állandó, ezért legfennebb egy megoldás lehet. Észrevehetö, hogy $g(1)=1$, vagyis $x=1$ jó, így $M=\{1\}$.

Megjegyzés: A diákok az egyenlet megoldását egyszerüen kitalálták, de a megoldás elején használt ötletet, miszerint áttértünk a két kifejezés egyenlőségéről azok inverzeinek egyenlőségére, nem ismerték, így együtt kellett elindulnunk. Ezt követően a többség, az apróbb hiányosságokat leszámítva, önállóan be tudta fejezni a feladatot.

4.3.8. Feladat. Oldd meg a $\sqrt[3]{x+22}=x^{3}-6 x^{2}+12 x-32$ egyenletet!

\section{Kérdések:}

- Mire emlékeztet az egyenlet jobb oldala? Hogyan tudnád átalakítani?

- Hogyan hozható a bal oldal hasonló formájúra?

- Mit veszel észre? Milyen viszonyban áll egymással az egyenlet két oldala?

- Mire lehet egy függvény és inverzének egyenlőségéből következtetni? Be tudnád látni ezt?

- Meg tudnád oldani az így kapott egyszerúbb egyenletet?

Megoldás: $x \in \mathbb{R}$ és először átalakítjuk az egyenlet mindkét oldalát:

$$
\sqrt[3]{x+22}=x^{3}-6 x^{2}+12 x-32 \Longleftrightarrow \sqrt[3]{(x-2)+24}=(x-2)^{3}-24 .
$$

Legyen $t:=x-2$, és tekintsük az

$$
f, g: \mathbb{R} \rightarrow \mathbb{R}, \quad f(t)=\sqrt[3]{t+24}, \quad g(t)=t^{3}-24
$$

függvényeket. Látható, hogy $f$ és $g$ szigorúan növekvő függvények egymás inverzeik, így grafikus képeik csak az első szögfelezőn metszhetik egymást. Ezért

$$
f(t)=g(t) \Longleftrightarrow g(t)=g^{-1}(t) \Longleftrightarrow g(t)=t,
$$

azaz

$$
t^{3}-24=t \quad \Longleftrightarrow \quad(t-3)\left(t^{2}+3 t+8\right)=0,
$$

amelynek egyetlen valós megoldása a $t=3$. Tehát az egyenlet megoldáshalmaza $M=\{5\}$.

Megjegyzés: Egy szigorúan növekvő függvény és inverzének egyenlőségéből adódó tulajdonság ismeretlen volt a diákok számára, így közösen beláttuk azt. A bizonyízásból ugyan kiderült, de ellenpéldákat vizsgálva külön kihangsúlyoztuk a szigorúan növekvő tulajdonság szükségességét és elégségességét, ugyanis ennek hiánya esetén nem föltétlen csak az első szögfelezőn metszik egymást a függvények grafikus képei. A bizonyított tulajdonság felhasználásával már minden diák önállóan is be tudta fejezni a megoldást. 
4.3.9. Feladat. Oldd meg az $\left\{\begin{array}{l}x-\sqrt{y}=1 \\ y-\sqrt{z}=1 \\ z-\sqrt{x}=1\end{array} \quad\right.$ egyenletrendszert!

\section{Kérdések:}

- Milyen szerkezetüek a rendszer egyenletei? Mit veszel észre?

- Át tudnád alakítani a rendszert? Hogyan tudnád kifejezni az egyik ismeretlent?

- Fel tudnál írni a három egyenlet alapján egy olyan egyenletet, amelyben csak az egyik ismeretlen szerepel?

- Milyen alakú ez az egyenlet? Mi következik ebből?

Megoldás: Mivel az egyenletekben csak két-két ismeretlen szerepel, ezért mindenikből kifejezve az elsőfokú tagot, majd egymásba helyettesítve egy egyismeretlenes egyenletet kapunk:

$$
\left\{\begin{array}{l}
x=1+\sqrt{y} \\
y=1+\sqrt{z} \\
z=1+\sqrt{x}
\end{array} \quad \Longrightarrow \quad x=1+\sqrt{1+\sqrt{1+\sqrt{x}}} .\right.
$$

Tekintsük az

$$
f: \mathbb{R}_{+} \rightarrow \mathbb{R}, f(x)=1+\sqrt{x}
$$

függvényt. Ekkor a fenti egyenlet $f(f(f(x)))=x$ alakba írható, és az $f \circ f \circ f$ függvény fixpontját keressük. Mivel $f$ szigorúan növekvö, ezért

$$
f(f(f(x)))=x \quad \Longleftrightarrow \quad f(x)=x \quad \Longleftrightarrow \quad 1+\sqrt{x}=x, x \geq 1,
$$

ahonnan rendezés, majd négyzetre emelés után kapjuk, hogy $x_{1,2}=\frac{3 \pm \sqrt{5}}{2}$, de az egyenletnek csak az $x=\frac{3+\sqrt{5}}{2}$ megoldása. Tehát $M=\left\{\left(\frac{3+\sqrt{5}}{2} ; \frac{3+\sqrt{5}}{2} ; \frac{3+\sqrt{5}}{2}\right)\right\}$.

Megjegyzés: Az előző feladat megoldásában alkalmazott tulajdonság egy következményét használtuk, miszerint, az $f$ szigorúan növekvő függvény fixpontja megegyezik az $f \circ f \circ \ldots \circ f$ függvény fixpontjával, azaz

$$
(\underbrace{f \circ f \circ \ldots \circ f}_{n-\text { szer }})(x)=x \Longleftrightarrow f(x)=x .
$$

A szigorú növekedés természetesen itt is szükséges és elégséges feltétel.

\section{Házi feladatok}

4.3.10. Feladat. Oldd meg a következő egyenleteket!
a) $2^{3 x^{2}-2 x^{3}}=\frac{x^{2}+1}{x}$
b) $2 \cos \frac{x}{3}=2^{x}+2^{-x}$
c) $3^{|\sin \sqrt{x}|}=|\cos x|$ 
Megoldás. a) Mivel a bal oldal pozitív, következik, hogy $\frac{x^{2}+1}{x}>0$, ahonnan $x>0$. Továbbá $\frac{x^{2}+1}{x}=x+\frac{1}{x} \geq 2$, mivel $x$ pozitív. Kimutatjuk, hogy $2^{3 x^{2}-2 x^{3}} \leq 2$, vagyis $3 x^{2}-2 x^{3} \leq 1$, ha $x>0$.

$$
\begin{gathered}
3 x^{2}-2 x^{3} \leq 1 \\
2 x^{2}-2 x^{3}+x^{2}-1 \leq 0 \\
2 x^{2}(1-x)+(x-1)(x+1) \leq 0 \\
\left(2 x^{2}-x-1\right)(1-x) \leq 0 \\
(2 x+1)(x-1)(1-x) \leq 0 \\
(2 x+1)(1-x)^{2} \geq 0,
\end{gathered}
$$

ami igaz bármely $x>0$ esetén, tehát $2^{3 x^{2}-2 x^{3}} \leq x+\frac{1}{x}$. Egyenlöség pontosan akkor teljesül, ha mindkét oldal 2, vagyis ha $x=1$. Tehát $M=\{1\}$.

b) Az egyenlet ekvivalens a $2 \cos \frac{x}{3}=2^{x}+\frac{1}{2^{x}}$ egyenlettel. De $2^{x}+\frac{1}{2^{x}} \geq 2, \forall x \in \mathbb{R}$ és $2 \cos \frac{x}{3} \leq 2, \forall x \in \mathbb{R}$. Tehát megoldás csak akkor lehet, ha $2^{x}+\frac{1}{2^{x}}=2$, vagyis $x=0$. Ez valóban megoldás, tehát $M=\{0\}$.

c) $|\sin \sqrt{x}| \geq 0$, tehát $3^{|\sin \sqrt{x}|} \geq 1$. Viszont $|\cos x| \leq 1$, tehát egyenlöség csak akkor lehet, ha $|\sin \sqrt{x}|=0$. Így $\sqrt{x} \in\{k \pi \mid k \in \mathbb{Z}\}$, ahonnan $x \in\left\{k^{2} \pi^{2} \mid k \in \mathbb{Z}\right\}$. Ugyanekkor a $|\cos x|=1$ egyenlöségnek is teljesülnie kell, ahonnan az $x \in\{k \pi \mid k \in \mathbb{Z}\}$ eredményhez jutunk. Tehát $x \in\left\{k^{2} \pi^{2} \mid k \in \mathbb{Z}\right\} \cap\{k \pi \mid k \in \mathbb{Z}\}=\{0\}$, így $M=\{0\}$.

4.3.11. Feladat. Oldd meg a valós számok halmazán az alábbi egyenleteket!
a) $2^{x^{2}-x}=1+2^{-x}\left(x^{2}-x\right)$
b) $\log _{2}\left(x^{2}+4\right)-\log _{2} x=7 x^{2}+4 x-x^{4}-18$

Megoldás. b) Az egyenlet a $(0, \infty)$ intervallumon értelmezett, és a

$$
\log _{2}\left(x^{2}+4\right)+\left(x^{2}+4\right)^{2}+\left(x^{2}+4\right)=\log _{2}(4 x)+(4 x)^{2}+(4 x)
$$

alakba írható, ahonnan az

$$
f:(0, \infty) \rightarrow \mathbb{R}, \quad f(x)=\log _{2} x+x^{2}+x
$$

függvény injektivitása miatt következik, hogy

$$
f\left(x^{2}+4\right)=f(4 x) \Longleftrightarrow x^{2}+4=4 x,
$$

így $M=\{2\}$.

4.3.12. Feladat. Oldd meg az alábbi egyenleteket!
a) $13^{5-2 x}=5 x+3$
b) $2^{x^{2}-x}+3^{x^{2}-x}=2 \cdot 5^{x^{2}-x}$ 
Megoldás. a) Az egyenlet értelmezési tartománya $D=\left(-\frac{3}{5}, \infty\right)$. Mivel az

$$
f: D \rightarrow \mathbb{R}, \quad f(x)=13^{5-2 x}
$$

függvény szigorúan csökkenő, míg a

$$
g: D \rightarrow \mathbb{R}, \quad g(x)=5 x+3
$$

függvény szigorúan növekvő, ezért az $f(x)=g(x)$ egyenletnek legtöbb egy megoldása lehet, és ez az $x=2$.

b) Az egyenlet értelmezett a teljes $\mathbb{R}-e n$, és

$$
\left(\frac{2}{5}\right)^{x^{2}-x}+\left(\frac{3}{5}\right)^{x^{2}-x}=2
$$

alakra hozható. Legyenek

$$
f, g: \mathbb{R} \rightarrow \mathbb{R}, \quad f(x)=\left(\frac{2}{5}\right)^{x^{2}-x}+\left(\frac{3}{5}\right)^{x^{2}-x}, \quad g(x)=x^{2}-x .
$$

Az $f$ függvény monotonitásának eldöntése végett tanulmányozzuk a $g$ függvény monotonitását.

i) Ha $x \in\left(-\infty, \frac{1}{2}\right]$, akkor g szigorúan csökkenő, vagyis

$$
\forall x_{1}, x_{2} \in\left(-\infty, \frac{1}{2}\right], x_{1}<x_{2} \Longrightarrow g\left(x_{1}\right)>g\left(x_{2}\right) \Longrightarrow f\left(x_{1}\right)<f\left(x_{2}\right),
$$

így $f$ szigorúan növekvő a $\left(-\infty, \frac{1}{2}\right]$ intervallumon, tehát az $f(x)=2$ egyenletnek legtöbb egy megoldása lehet, és ez az $x=0$.

ii) Ha $x \in\left[\frac{1}{2}, \infty\right)$, akkor g szigorúan növekvő, vagyis

$$
\forall x_{1}, x_{2} \in\left[\frac{1}{2}, \infty\right), x_{1}<x_{2} \Longrightarrow g\left(x_{1}\right)<g\left(x_{2}\right) \Longrightarrow f\left(x_{1}\right)>f\left(x_{2}\right),
$$

így $f$ szigorúan csökkenő az $\left[\frac{1}{2}, \infty\right)$ intervallumon, tehát az $f(x)=2$ egyenletnek legtöbb egy megoldása lehet, és ez az $x=1$.

Összességében tehát $M=\{0 ; 1\}$.

4.3.13. Feladat. Oldd meg az alábbi egyenleteket!

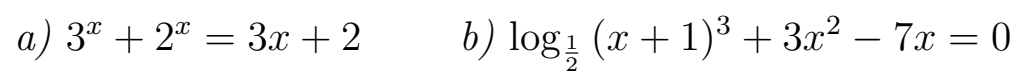

Megoldás. a) Az egyenlet a valós számok halmazán értelmezett. A bal oldal két szigorúan konvex exponenciális függvény összege lévén szigorúan konvex a valós számok halmazán, míg a jobb oldal elsőfokú, így az egyenletnek legtöbb két megoldása lehet, és ezek $x=0$ és $x=1$.

b) Az egyenlet a $(-1, \infty)$ intervallumon értelmezett, és egyenértékü az

$$
\log _{\frac{1}{2}}(x+1)=-x^{2}+\frac{7}{3} x
$$

egyenlettel. A bal oldali függvény szigorúan konvex, míg a jobb oldali szigorúan konkáv a $(-1, \infty)$ intervallumon, így az egyenletnek legtöbb két megoldása lehet, és ezek az $x=0$ és $x=3$. 
4.3.14. Feladat. Oldd meg az alábbi egyenleteket!

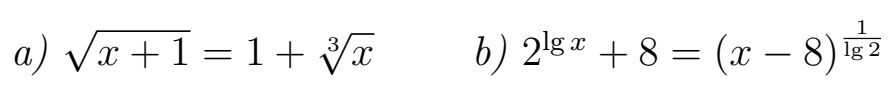

Megoldás. a) Az egyenlet a $[-1, \infty)$ intervallumon értelmezett, és az

$$
y=\sqrt{x+1}=1+\sqrt[3]{x}
$$

helyettesítést használva mindkét összefüggésből kifejezzük $x$-et. Mivel az

$$
y=\sqrt{x+1}:[-1, \infty) \rightarrow[0, \infty), \quad y=1+\sqrt[3]{x}: \mathbb{R} \rightarrow \mathbb{R}
$$

függvények bijektívek, ezért

$$
x=y^{2}-1, \quad \text { illetve } \quad x=(y-1)^{3},
$$

összefüggéseket kapjuk, majd megoldva az

$$
(y-1)^{3}=y^{2}-1 \quad \Longleftrightarrow \quad y(y-1)(y-3)=0
$$

egyenletet, $y_{1}=0, y_{2}=1, y_{3}=3$ megoldások adódnak, így az eredeti egyenlet megoldáshalmaza $M=\{-1,0,8\}$.

4.3.15. Feladat. Oldd meg az $x^{3}+1=2 \sqrt[3]{2 x-1}$ egyenleteket!

\section{Megoldás.}

$$
x^{3}+1=2 \sqrt[3]{2 x-1} \Longleftrightarrow \frac{x^{3}+1}{2}=\sqrt[3]{2 x-1} .
$$

Észrevehető, hogy ha tekintjük az

$$
f: \mathbb{R} \rightarrow \mathbb{R}, f(x)=\frac{x^{3}+1}{2}
$$

bijektív függvényt, akkor

$$
f^{-1}(x)=\sqrt[3]{2 x-1}
$$

és az egyenlet $f(x)=f^{-1}(x)$ alakban írható. Mivel $f$ szigorúan növekvő, ezért

$$
f(x)=f^{-1}(x) \Longleftrightarrow f(x)=x,
$$

ahonnan kapjuk, hogy

$$
\frac{x^{3}+1}{2}=x \quad \Longleftrightarrow \quad x^{3}-2 x+1=0 \quad \Longleftrightarrow \quad(x-1)\left(x^{2}+x-1\right)=0 .
$$

Tehát $x_{1}=1$ és $x_{2,3}=\frac{-1 \pm \sqrt{5}}{2}$.

4.3.16. Feladat. Ha $a>0$, oldd meg az $\left\{\begin{array}{c}x_{1}-\sqrt{x_{2}}=a \\ x_{2}-\sqrt{x_{3}}=a \\ \vdots \\ x_{n}-\sqrt{x_{1}}=a\end{array} \quad\right.$ egyenletrendszert! 
Megoldás. A 4.3.9. feladat általánosítása.

4.3.17. Feladat. Az azonos alapú és alappal szemközti azonos szögü háromszögek közül melyiknek legnagyobb a kerülete?

Megoldás. A feladat feltételeit teljesítő háromszögek harmadik csúcsa az alap fölé rajzolt, $\alpha$-szögü látóköríven helyezkednek el. (4.48. ábra)

A szinusztételből következik, hogy

$$
b=a \cdot \frac{\sin \beta}{\sin \alpha}, \quad \text { illetve } \quad c=a \cdot \frac{\sin \gamma}{\sin \alpha} .
$$

Ekkor

$$
K=a+b+c=a+a \cdot \frac{\sin \beta+\sin \gamma}{\sin \alpha},
$$

ami akkor maximális, amikor $\sin \beta+\sin \gamma$ is maximális.

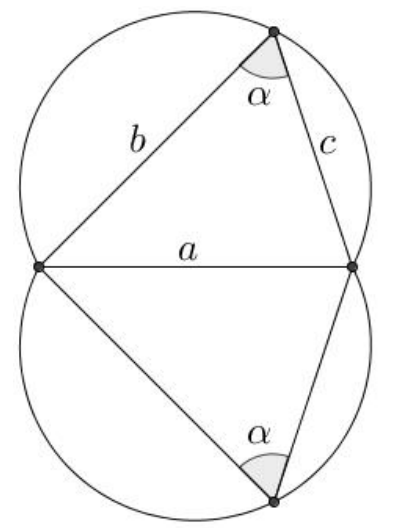

4.48. ábra. A látókörívek

Mivel az $f: \mathbb{R} \rightarrow \mathbb{R}, f(x)=\sin x$ függvény konkáv a $[0 ; \pi]$ intervallumon, ezért a Jensen-egyenlőtlenség alapján

$$
\sin \beta+\sin \gamma \leq 2 \cdot \sin \frac{\beta+\gamma}{2}=2 \cdot \sin \left(90^{\circ}-\frac{\alpha}{2}\right) .
$$

Tehát az összeg maximális, ha az egyenlőtlenségben egyenlőség áll fenn, azaz

$$
\beta=\gamma=90^{\circ}-\frac{\alpha}{2}
$$

Ekkor a háromszög egyenlő szárú.

4.3.18. Feladat. Határozd meg az $x+\frac{1}{x}-\sqrt{x^{2}+\frac{1}{x^{2}}}$ kifejezés legnagyobb és legkisebb értékét, ha $x$ pozitiv valós szám!

Megoldás. Legyen $f:(0,+\infty) \rightarrow \mathbb{R}, f(x)=x+\frac{1}{x}-\sqrt{x^{2}+\frac{1}{x^{2}}}$. (4.49. ábra) 


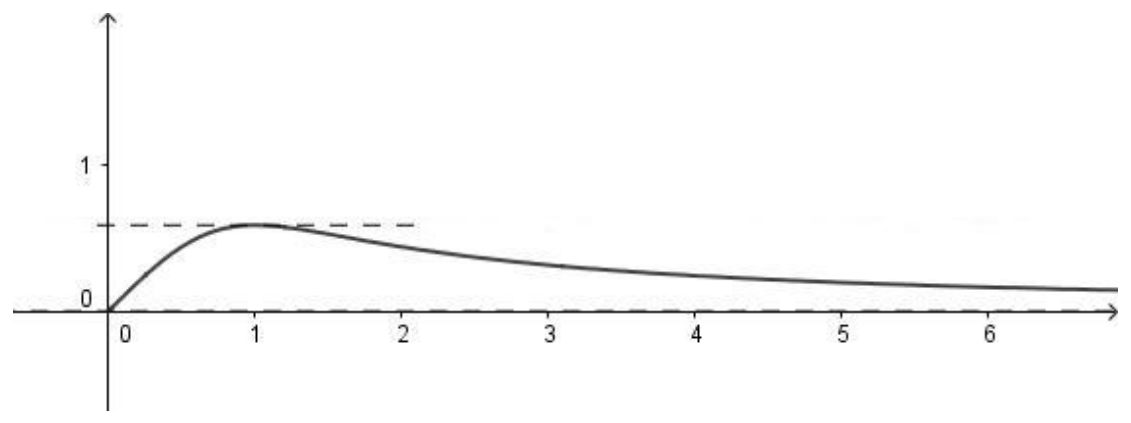

4.49. ábra. Az $f$ függvény grafikus képe

Átalakítjuk a függvény leképezési törvényét bővítve a különbséget a konjugáltjával. Ekkor

$$
f(x)=x+\frac{1}{x}-\sqrt{x^{2}+\frac{1}{x^{2}}}=\frac{\left(x+\frac{1}{x}\right)^{2}-\left(x^{2}+\frac{1}{x^{2}}\right)}{x+\frac{1}{x}+\sqrt{x^{2}+\frac{1}{x^{2}}}}=\frac{2}{x+\frac{1}{x}+\sqrt{x^{2}+\frac{1}{x^{2}}}} .
$$

Mivel a számláló állandó, ezért a függvény akkor maximális, amikor a nevező minimális. De $x+\frac{1}{x} \geq 2$, és $x^{2}+\frac{1}{x^{2}} \geq 2, \forall x>0$ esetén, ezért

$$
f(x) \leq \frac{2}{2+\sqrt{2}}=2-\sqrt{2}, \quad \forall x>0,
$$

és ezt az értéket a függvény fel is veszi az $x=1$ pontban. Tehát a maximum $2-\sqrt{2}$.

Ugyanakkor nem létezik a függvénynek minimuma, hiszen $\lim _{x \searrow 0} f(x)=\lim _{x \rightarrow \infty} f(x)=0$, és ezt nem veszi fel. A függvénynek vízszintes aszimptotája az $y=0$ egyenletü egyenes.

\subsubsection{A matematikai analízis elemeinek alkalmazása}

A differenciál- és integrálszámítás a 11., illetve 12. osztályos romániai matematikatanítás központi eleme, így hangsúlyosan végigkíséri e két évfolyam tananyagát. A számtalan elemi, de akár többszörösen összetett függvény deriválása és a különböző integrálszámítási technikák mellett, a terület és térfogatszámítást leszámítva, kevés idő jut az analízis eszközeinek akár a matematikán belüli alkalmazásának tárgyalására. Ennek a hiánynak a pótlása érdekében végül olyan problémákat tanulmányoztunk, melyek megoldása igen egyszerü differenciál-, esetleg integrálszámítás bevonásával. Természetesen utóbbiakra csak az egyetemi hallgatók körében került sor.

\section{Órán megoldott feladatok}

4.3.19. Feladat. Határozd meg az $S=\frac{1}{2}+\frac{2}{4}+\frac{3}{8}+\ldots+\frac{100}{2^{100}}$ összeg egész részét!

\section{Kérdések:}

- Milyen alakúak az összeg tagjai?

- Találkoztál már hasonló formájú összeggel? 
- Egy tag esetén milyen művelettel hozható be formálisan eggyel nagyobb szám együtthatónak, mint az illető tag fokszáma?

- Zárt alakba tudnád hozni az összeget? Mennyi az egész része?

- Általánosabban meg tudnád vizsgálni a feladatot?

Megoldás: Megpróbáljuk az összeget zárt alakba hozni.

$$
S=\sum_{k=1}^{100} \frac{k}{2^{k}}=\frac{1}{2} \sum_{k=1}^{100} k \cdot\left(\frac{1}{2}\right)^{k-1}
$$

Hasonló összeg előállítható az $f:(0,1) \rightarrow \mathbb{R}, f(x)=x+x^{2}+\ldots+x^{100}$ függvényt deriválva, hiszen $f^{\prime}(x)=1+2 x+\ldots+100 \cdot x^{99}$, ahonnan

$$
f^{\prime}\left(\frac{1}{2}\right)=1+2 \cdot \frac{1}{2}+3 \cdot\left(\frac{1}{2}\right)^{2}+\ldots+100 \cdot\left(\frac{1}{2}\right)^{99}=2 S .
$$

De mivel az $f(x)$ tagjai mértani haladványban vannak, ezért $f(x)=\frac{x^{101}-x}{x-1}$, ahonnan

$$
f^{\prime}(x)=\frac{100 \cdot x^{101}-101 \cdot x^{100}+1}{(x-1)^{2}}
$$

Tehát

$$
S=\frac{f^{\prime}\left(\frac{1}{2}\right)}{2}=2\left(\frac{100}{2^{101}}-\frac{101}{2^{100}}+1\right)=2-\frac{51}{2^{99}} \in(1,2),
$$

így az összeg egész része 1.

Söt, általában $\sum_{k=1}^{n} \frac{k}{2^{k}}=2-\frac{n+2}{2^{n}} \in(1,2), \forall n \in \mathbb{N} \backslash\{0 ; 1\}$, ezért egész része 1 .

Megjegyzés: Az összegben szereplő tagok formájának megfelelö ideig való tanulmányozása után, elég sok diáknak eszébe jutott a használt hatványösszeg és annak deriválása. A további számítások elvégzése nem okozott különösebb problémát a többségnek.

4.3.20. Feladat. Számítsd ki az alábbi összegeket!

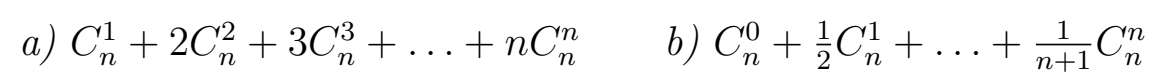

\section{Kérdések:}

- Milyen alakúak az összeg tagjai? Találkoztál már hasonló formájú összeggel?

- Minek a kifejtése vezethet hasonló alakú összeghez? Fel tudnád írni?

- Milyen müvelettel „hozhatók le” a kitevők együtthatónak? Hogyan „hozhatók be” formálisan a nevezőbe a kitevők?

- A felírt azonosság zárt alakja ekkor hogyan alakul? 
Megoldás: a) A keresett összeghez hasonlót állíthatunk elő, ha Newton binomiális képlete szerint felírjuk az $(1+x)^{n}$ kifejezés kibontott alakját.

$$
(1+x)^{n}=1+x \cdot C_{n}^{1}+x^{2} \cdot C_{n}^{2}+\ldots+x^{n} \cdot C_{n}^{n}, \forall x \in \mathbb{R}, n \in \mathbb{N}^{*} .
$$

A kért összeg előállítása érdekében mindenik tagban meg kellene jelenjenek a kombinációk rendjének megfelelő természetes számok, ezért deriváljuk a felírt összefüggés mindkét oldalát $x$ szerint. Ekkor

$$
n(1+x)^{n-1}=0+1 \cdot C_{n}^{1}+2 x \cdot C_{n}^{2}+\ldots+n x^{n-1} \cdot C_{n}^{n}
$$

A kapott összefüggésbe $x=1$-et helyettesítve éppen a kért összeghez jutunk:

$$
C_{n}^{1}+2 C_{n}^{2}+3 C_{n}^{3}+\ldots+n C_{n}^{n}=n \cdot 2^{n-1}
$$

b) Mivel a tagok nevezőiben a kombinációk rendjénél eggyel nagyobb számok kellene megjelenjenek, ezért az

$$
(1+x)^{n}=1+x \cdot C_{n}^{1}+x^{2} \cdot C_{n}^{2}+\ldots+x^{n} \cdot C_{n}^{n}, \forall x \in \mathbb{R}, n \in \mathbb{N}^{*} .
$$

összefüggés mindkét oldalát integráljuk $x$ szerint a $[0,1]$-on. Ekkor

$$
\begin{gathered}
\int_{0}^{1}(1+x)^{n} d x=\int_{0}^{1}\left(1+x \cdot C_{n}^{1}+x^{2} \cdot C_{n}^{2}+\ldots+x^{n} \cdot C_{n}^{n}\right) d x \\
\left.\frac{(1+x)^{n+1}}{n+1}\right|_{0} ^{1}=x+\frac{x^{2}}{2} C_{n}^{1}+\frac{x^{3}}{3} C_{n}^{2}+\ldots+\left.\frac{x^{n+1}}{n+1} C_{n}^{n}\right|_{0} ^{1} \\
\frac{2^{n+1}}{n+1}-\frac{1}{n+1}=1+\frac{1}{2} C_{n}^{1}+\frac{1}{3} C_{n}^{2}+\ldots+\frac{1}{n+1} C_{n}^{n}
\end{gathered}
$$

Tehát

$$
C_{n}^{0}+\frac{1}{2} C_{n}^{1}+\ldots+\frac{1}{n+1} C_{n}^{n}=\frac{2^{n+1}-1}{n+1} .
$$

Megjegyzés: A kezdőlépés állította nagyobb dilemma elé a diákokat, a további számítások elvégzése nem okozott különösebb problémát a többségnek.

4.3.21. Feladat. Melyik szám nagyobb: $e^{\pi}$ vagy $\pi^{e}$ ?

\section{Kérdések:}

- Általánosabban milyen viszonyban van $e^{x}$ és $x^{e}$ értéke, ha $x>0$ ?

- Át tudnád alakítani az $e^{x} \geq x^{e}$ egyenlőtlenséget úgy, hogy könnyebben belátható legyen?

- Hogyan határozható meg a kapott függvény maximuma? 
Megoldás: Vizsgáljuk általánosabban a problémát! Hogyan viszonyul $e^{x}$ kifejezés értéke az $x^{e}$ kifejezés értékéhez $x>0$ esetén? Ennek érdekében oldjuk meg az $e^{x} \geq x^{e}$ egyenlötlenséget!

Logaritmálva az egyenlőtlenség mindkét oldalát kapjuk, hogy

$$
e^{x} \geq x^{e} \Longleftrightarrow x \ln e \geq e \ln x \quad \Longleftrightarrow \quad \frac{\ln x}{x} \leq \frac{1}{e} .
$$

Deriválva, majd tanulmányozva az

$$
f:(0, \infty) \rightarrow \mathbb{R}, \quad f(x)=\frac{\ln x}{x}
$$

függvény szélsőértékeit, kiderül, hogy

$$
f(x) \leq f(e), \quad \forall x>0 \quad \Longleftrightarrow \quad \frac{\ln x}{x} \leq \frac{1}{e}, \quad \forall x>0
$$

tehát

$$
e^{x} \geq x^{e}, \quad \forall x>0
$$

így

$$
e^{\pi}>\pi^{e}
$$

Megjegyzés: Bár hasonló kérdések egy átlagos analízisórán is előjönnek, mégis, mivel a feladat a többségnek nehéznek bizonyult, a segítö kérdésekre adott válaszokat követve, együtt oldottuk meg azt.

4.3.22. Feladat. Oldd meg a $3^{x}+4^{x}=2^{x}+5^{x}$ egyenlet!

\section{Kérdések:}

- Hogyan tudnád különbségek egyenlőségévé alakítani az egyenletet?

- Mely intervallumokon alkalmaznád formálisan Lagrange tételét az $x$ kitevős hatványfüggvényre, hogy ilyen alakú különbségek jelenjenek meg?

- Meg tudnád oldani az így adódó egyenletet?

Megoldás: Az egyenlet $\mathbb{R}$-en értelmezett, és

$$
3^{x}-2^{x}=5^{x}-4^{x}
$$

alakba írható. Mivel az

$$
f: \mathbb{R} \rightarrow \mathbb{R}, \quad f(t)=t^{x}
$$

függvény ( $t$ a változó) folytonos és deriválható a $[2,3]$ és a $[4,5]$ intervallumokon, ezért alkalmazható rá a Lagrange-tétel a fenti intervallumokon.

A Lagrange-tétel szerint létezik $c_{1} \in(2,3)$ úgy, hogy

$$
f^{\prime}\left(c_{1}\right)=\frac{f(3)-f(2)}{3-2} \Longleftrightarrow 3^{x}-2^{x}=x \cdot c_{1}^{x-1}
$$


és létezik $c_{2} \in(4,5)$ úgy, hogy

$$
f^{\prime}\left(c_{2}\right)=\frac{f(5)-f(4)}{5-4} \Longleftrightarrow 5^{x}-4^{x}=x \cdot c_{2}^{x-1} .
$$

Így az adott egyenlet helyett az $x \cdot c_{1}^{x-1}=x \cdot c_{2}^{x-1}$ egyenlettel foglalkozunk.

$$
x \cdot c_{1}^{x-1}=x \cdot c_{2}^{x-1} \Longleftrightarrow x \cdot\left(c_{1}^{x-1}-c_{2}^{x-1}\right)=0 \quad \Longleftrightarrow \quad x=0,
$$

vagy

$$
c_{1}^{x-1}-c_{2}^{x-1}=0 \quad \Longleftrightarrow \quad\left(\frac{c_{1}}{c_{2}}\right)^{x-1}=1, \quad \frac{c_{1}}{c_{2}} \in(0,1),
$$

ahonnan

$$
x-1=0 \quad \Longleftrightarrow \quad x=1
$$

Összességében $M=\{0 ; 1\}$.

Megjegyzés: Ezt a feladatot szintén közösen oldottuk meg.

4.3.23. Feladat. Egyenes körkúpba érintögömböt írunk. Mekkora a kúp nyílásszöge, ha a gömb a kúpból maximális térfogatot foglal el, és hányad része ez a kúp térfogatának?

\section{Kérdések:}

- Milyen információk adottak? Mit kér a feladat?

- Hogyan tudnád felírni a kúp, illetve a gömb térfogatát a nyílásszög segítségével?

- Mennyi ekkor a hányadosuk? Meg tudnád határozni a maximumát?

- Hogyan becsülhető elemi úton ez az érték?

- Mikor van a felírt becslésben egyenlöség?

Megoldás: A 4.50. ábra jelöléseit használva $R=h \cdot \operatorname{tg} \alpha$ és $r=(h-r) \sin \alpha$, ahonnan

$$
r=\frac{h \cdot \sin \alpha}{1+\sin \alpha}
$$

Ekkor a kúp térfogata

$$
V_{k}=\frac{R^{2} \pi h}{3}=\frac{(h \operatorname{tg} \alpha)^{2} \pi h}{3}
$$

a gömb térfogata pedig

$$
V_{g}=\frac{4 \pi r^{3}}{3}=\frac{4 \pi}{3}\left(\frac{h \sin \alpha}{1+\sin \alpha}\right)^{3} .
$$

Keressük a $\frac{V_{g}}{V_{k}}$ maximumát!

$$
\frac{V_{g}}{V_{k}}=\frac{4 \sin \alpha\left(1-\sin ^{2} \alpha\right)}{(1+\sin \alpha)^{3}}=\frac{4 \sin \alpha(1-\sin \alpha)}{(1+\sin \alpha)^{2}} .
$$




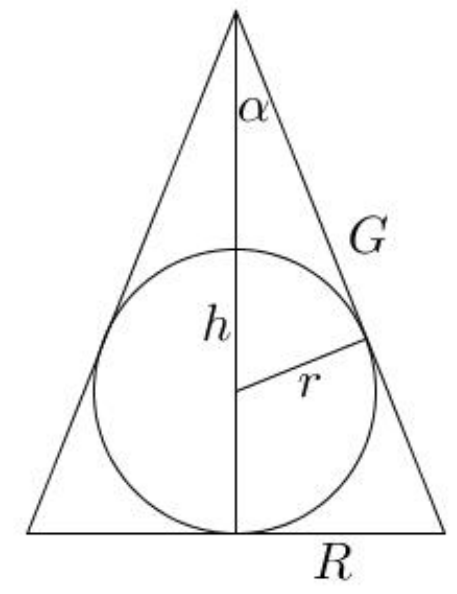

4.50. ábra. A kúp tengelymetszete

Jobb ötlet nem lévén, differenciálszámításbeli eszközökkel meghatározzuk az

$$
f:\left(0, \frac{\pi}{2}\right) \rightarrow \mathbb{R}, \quad f(x)=\frac{\sin x(1-\sin x)}{(1+\sin x)^{2}}
$$

függvény maximumát. A függvény deriváltja

$$
f^{\prime}(x)=\frac{\cos x(1-3 \sin x)}{(1+\sin x)^{3}}, x \in\left(0, \frac{\pi}{2}\right)
$$

ami $\sin x=\frac{1}{3}$ esetén nulla, előtte pozitív, majd negatív, tehát az $f$ függvénynek maximuma van, amelyet $x=\arcsin \left(\frac{1}{3}\right)$ esetén vesz fel és a függvény maximuma $\frac{1}{2}$.

Ekkor $\alpha \approx 19^{\circ} 28^{\prime}$, a kúp nyílásszöge $38^{\circ} 56^{\prime}$, a térfogatok aránya pedig $\frac{1}{2}$.

Elemi becslés: Mivel $\alpha$ hegyesszög, így $\sin \alpha>0,1 \pm \sin \alpha>0$, és két szám mértani és számtani közepe közötti egyenlőtlenséget felhasználva felülről becsüljük az arány értékét.

$$
\frac{V_{g}}{V_{k}}=2 \cdot \frac{2 \sin \alpha}{1+\sin \alpha} \cdot \frac{1-\sin \alpha}{1+\sin \alpha} \leq \frac{1}{2} \cdot\left(\frac{2 \sin \alpha}{1+\sin \alpha}+\frac{1-\sin \alpha}{1+\sin \alpha}\right)^{2}=\frac{1}{2}
$$

Tehát a maximum $\frac{1}{2}$, és ezt akkor éri el, amikor a számtani és mértani közepek közötti egyenlőtlenségben egyenlőség áll fenn, vagyis ha

$$
\frac{2 \sin \alpha}{1+\sin \alpha}=\frac{1-\sin \alpha}{1+\sin \alpha}
$$

ahonnan

$$
\sin \alpha=\frac{1}{3}
$$

Mivel $x \mapsto \sin \alpha$ szigorúan monoton a $\left(0, \frac{\pi}{2}\right)$ intervallumon, ezért az arány pontosan akkor maximális, amikor $\alpha=19^{\circ} 28^{\prime}$, azaz a kúp nyílásszöge $38^{\circ} 56^{\prime}$. Ekkor $\frac{V_{g}}{V_{k}}=\frac{1}{2}$.

Megjegyzés: A feladat teljesen ismeretlen volt a diákok számára, ugyanis a térmértan oktatása Romániában 8. osztályban véget ér, így hasonló komplexitású geometriafeladatokra nem kerül sor a tanórákon. Némi segítséggel sikerült felírniuk a gömb és kúp 
térfogatának arányát, majd az alkalmas függvény megtalálása után a szélsőérték nem elemi, differenciálszámításbeli eszközökkel való keresésére a precízebb diákoknak már nem okozott különösebb gondot. Viszont az elemi úton, egyenlőtlenségekkel történő becslés már nagy nehézséget okozott, ezért együtt végeztük el azt. Éppen az újszerúsége miatt, a diákok érdekesnek találták a feladatot.

\section{Házi feladatok}

4.3.24. Feladat. Számítsd ki az alábbi összegeket!

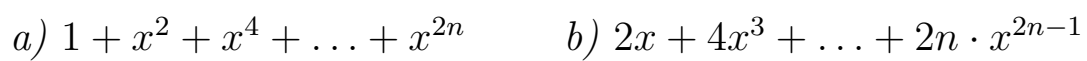

Megoldás. a) Az első összeg tagjai mértani sorozatot alkotnak, így

$$
1+x^{2}+x^{4}+\ldots+x^{2 n}=\frac{x^{2 n+2}-1}{x^{2}-1} .
$$

b) Az első összeget formálisan deriválva éppen a második összeget kapjuk, ezért

$$
\begin{gathered}
2 x+4 x^{3}+\ldots+2 n \cdot x^{2 n-1}=\left(1+x^{2}+x^{4}+\ldots+x^{2 n}\right)^{\prime}= \\
=\left(\frac{x^{2 n+2}-1}{x^{2}-1}\right)^{\prime}=\frac{2 n x^{2 n+3}-(2 n+2) x^{2 n+1}-2 x^{2 n+3}}{\left(x^{2}-1\right)^{2}} .
\end{gathered}
$$

4.3.25. Feladat. Oldd meg a $\left(8^{x}+1\right)(1-x)=2$ egyenlet!

Megoldás. Az egyenlet $\mathbb{R}$-en értelmezett. Tekintsük az

$$
f:(-\infty, 1) \rightarrow \mathbb{R}, \quad f(x)=\left(8^{x}+1\right)(1-x)-2
$$

függvényt, amelynek első-, illetve másodrendü deriváltjai

$$
f^{\prime}(x)=-\left(8^{x}+1\right)+(1-x) 8^{x} \ln 8
$$

és

$$
f^{\prime \prime}(x)=8^{x} \ln 8[(1-x) \ln 8-2] .
$$

Mivel az

$$
f^{\prime \prime}(x)=0 \quad \Longleftrightarrow \quad x=1-\frac{2}{\ln 8} \in(-\infty, 1),
$$

a Rolle-tétel következménye értelmében az $f^{\prime}(x)=0$ egyenletnek legtöbb két megoldása van, így az $f(x)=0$ egyenletnek legtöbb három megoldása lehet. Mivel $f(0)=f\left(-\frac{1}{3}\right)=$ $f\left(\frac{1}{3}\right)=0$, ezért az eredeti egyenlet megoldáshalmaza $M=\left\{-\frac{1}{3}, 0, \frac{1}{3}\right\}$.

4.3.26. Feladat. Oldd meg a $3^{x}+6^{x}=5^{x}+4^{x}$ egyenlet!

Megoldás. A megoldás teljesen hasonló a 4.3.22. feladatéhoz.

4.3.27. Feladat. A Lagrange-tétel felhasználásával igazold, hogy $\operatorname{tg} \frac{5 \pi}{18}>1+\frac{\pi}{18}$. 
Megoldás.

majd alkalmazzuk Lagrange tételét az

$$
\operatorname{tg} \frac{5 \pi}{18}>1+\frac{\pi}{18} \Longleftrightarrow \operatorname{tg} \frac{5 \pi}{18}-\operatorname{tg} \frac{\pi}{4}>\frac{\pi}{18}
$$

$$
f:\left[\frac{\pi}{4}, \frac{5 \pi}{18}\right] \rightarrow \mathbb{R}, \quad f(x)=\operatorname{tg} x
$$

folytonos és a $\left(\frac{\pi}{4}, \frac{5 \pi}{18}\right)$ intervallumon deriválható függvényre.

4.3.28. Feladat. Gömb köré forgáskúpot írunk. Legalább mekkora a kúp felszíne?

Megoldás. A 4.51. ábra jelöléseit használva, legyen az egyszerüség kedvéért $r=1$. Ekkor a kúp felszíne

$$
F=R^{2} \pi+R \cdot \pi \cdot G
$$

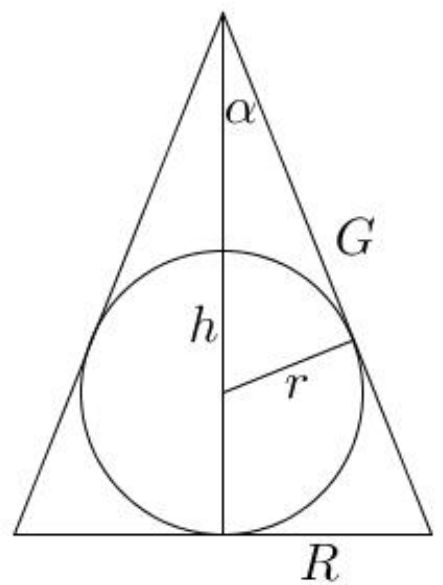

4.51. ábra. A kúp tengelymetszete

Felhasználva, hogy egy külső pontból a körhöz húzott érintők kongruensek, és hogy $h=\sqrt{G^{2}-R^{2}}$, a 4.51. ábrán levő hasonló derékszögű háromszögek miatt

$$
\frac{1}{G-R}=\frac{R}{\sqrt{G^{2}-R^{2}}} \Longrightarrow \frac{1}{(G-R)^{2}}=\frac{R^{2}}{(G-R)(G+R)} \quad \Longrightarrow \quad G=\frac{R\left(R^{2}+1\right)}{R^{2}-1} .
$$

Ezt behelyettesítve a felszínre felírt összefüggésbe

$$
F=\pi\left(R^{2}+R^{2} \cdot \frac{R^{2}+1}{R^{2}-1}\right)=\frac{2 \pi R^{4}}{R^{2}-1} .
$$

Keressük az $f:(1, \infty) \rightarrow \mathbb{R}, f(x)=\frac{x^{4}}{x^{2}-1}$ függvény minimumát!

$$
f^{\prime}(x)=\frac{2 x^{3}\left(x^{2}-2\right)}{\left(x^{2}-1\right)^{2}}, x>1
$$

ami $x=\sqrt{2}$ esetén nulla, előtte a deriváltfüggvény negatív, majd utána pozitív, tehát az $x=\sqrt{2}$ a függvény minimumhelye, minimuma pedig 4 . 
A fentiek szerint egység sugarú gömb esetén a kúp $F$ felszíne legalább $8 \pi$, és ekkor a kúp sugara $R=\sqrt{2}$. Ha pedig a gömb sugara $r$, akkor a minimális felszín $8 \pi r^{2}$.

Elemi becslés: Észrevehető, hogy

$$
F=2 \pi \frac{R^{4}}{R^{2}-1}=2 \pi\left(R^{2}-1+\frac{1}{R^{2}-1}+2\right)
$$

aminek a legkisebb értékéhez elegendő meghatározni az

$$
R^{2}-1+\frac{1}{R^{2}-1}
$$

kifejezés minimumát. Mivel $R>1$, az előbbi kifejezés pontosan akkor minimális, amikor

$$
R^{2}-1=\frac{1}{R^{2}-1} \quad \Longleftrightarrow \quad R^{2}-1=1 \quad \Longleftrightarrow \quad R^{2}=2,
$$

vagyis ha $R=\sqrt{2}$. Ekkor a kúp felszíne $F=8 \pi$.

Megjegyzés: Ekkor a kúp alkotója $G=3 \sqrt{2}$, és így $\sin \alpha=\frac{1}{3}$, ugyanúgy mint a 4.3.23. feladatban. A gömb felszíne $4 \pi$, így a felszínek aránya $1: 2$.

Tehát ha a gömb a kúpból maximális térfogatot foglal el, akkor a gömb és a kúp felszínének aránya is maximális, és mindkét arány $\frac{1}{2}$. 


\section{5. fejezet}

\section{Az utómérés anyaga és értékelése}

\subsection{A mérés célja és módszere}

A három hónapos tevékenységsorozatot követően a diákok egy zárómérésen vettek részt. Az előteszthez hasonlóan 90 perc alatt három, számukra ismeretlen problémát kellett minél részletesebben és akár többféle módszerrel megoldaniuk. A dolgozatlapot függőlegesen kettéosztva bal oldara került a problémák megoldásának kidolgozása, míg ezzel párhuzamosan a jobb oldalon a diákok a gondolataikról, metakognitív tevékenységükről számoltak be.

A feladatok a következő képességek mérésére szolgáltak:

- kísérletezés alapján történő sejtések megfogalmazása, majd azok bizonyítása

- a különböző tananyagrészek összekapcsolása adott probléma megoldása során

- különböző reprezentációkban való gondolkodás, vizuális problémareprezentációk alkotása, elemzése

- a transzformációelv mint általános heurisztikus eljárás alkalmazása

Ezek mellett a diákoknak a problémamegoldási folyamatot végigkísérő tudatos metakognitív tevékenységének változására, fejlődésére is kíváncsi voltam.

\subsection{A feladatok megoldása és értékelése}

\section{Feladatok}

1. Határozd meg az $x^{2}+y^{2}$ kifejezés lehetséges legkisebb értékét, ha $5 x+y=7$ és $x, y \in \mathbb{R}$.

2. Határozd meg a $2 x y+2 y z+x z$ kifejezés értékét, ha az $x, y, z>0$ számok teljesítik a $3 x^{2}+4 y^{2}+6 x y=169, \quad 4 y^{2}+z^{2}-2 y z=25, \quad 3 x^{2}+z^{2}+3 x z=144$ összefüggéseket!

3. Oldd meg a $\left(2^{x}-1\right)^{2}=\log _{2}(\sqrt{x}+1), x \geq 0$ egyenletet! 


\section{Megoldások}

1. feladat. Határozd meg az $x^{2}+y^{2}$ kifejezés lehetséges legkisebb értékét, ha $5 x+y=7$ és $x, y \in \mathbb{R}$.

1. megoldás. A megadott összefüggésből kifejezzük az egyik változót a másik függvényében, majd behelyettesítjük a vizsgálandó kifejezésbe, így az már csak egy változótól függő másodfokú kifejezés lesz, melynek a minimuma könnyen meghatározható.

$$
\begin{gathered}
y+5 x=7 \quad \Longleftrightarrow \quad y=7-5 x \\
\min \left(x^{2}+y^{2}\right)=\min \left(26 x^{2}-70 x+49\right)=-\frac{\Delta}{4 a}=-\frac{70^{2}-4 \cdot 26 \cdot 49}{4 \cdot 26}=\frac{49}{26}
\end{gathered}
$$

2. megoldás. Alkalmazzuk a Cauchy - Bunyakovszkij - Schwarz - egyenlőtlenséget a

$$
\overrightarrow{v_{1}}=(5,1) \quad \text { és } \quad \overrightarrow{v_{2}}=(x, y)
$$

vektorokra. Ekkor

$$
\left|\overrightarrow{v_{1}} \cdot \overrightarrow{v_{2}}\right| \leq\left|\overrightarrow{v_{1}}\right| \cdot\left|\overrightarrow{v_{2}}\right|
$$

ahonnan

$$
7=|5 \cdot x+1 \cdot y| \leq \sqrt{5^{2}+1^{2}} \cdot \sqrt{x^{2}+y^{2}}=\sqrt{26} \cdot \sqrt{x^{2}+y^{2}}
$$

vagyis

$$
\frac{7}{\sqrt{26}} \leq \sqrt{x^{2}+y^{2}} \Longleftrightarrow \frac{49}{26} \leq x^{2}+y^{2}
$$

Tehát az $x^{2}+y^{2}$ kifejezés minimuma $\frac{49}{26}$.

3. megoldás. A feladat geometriailag is megközelíthetö, hiszen az $5 x+y-7=0$ összefüggés egy síkbeli $e$ egyenes egyenlete, míg az $x^{2}+y^{2}$ kifejezés egy $M(x, y) \in$ $e$ pont origótól mért távolságnégyzetét jelenti. Tehát feladatunk az, hogy meghatározzuk az adott egyenesen mozgó $M$ pont origótól való távolságnégyzetének minimumát. Ez a távolság akkor minimális, amikor $O M \perp e$, tehát feladatunk az origó és az egyenes közti távolság négyzetének meghatározása.

$$
\min \left(x^{2}+y^{2}\right)=\min |O M|^{2}=d^{2}(O, e)=\frac{|5 \cdot 0+1 \cdot 0-7|}{\sqrt{5^{2}+1^{2}}}=\frac{49}{26}
$$

4. megoldás. Az előző megoldásban szereplő gondolatmenethez hasonlóan meghatározzuk az e egyenesre merőleges $e^{\prime}$ egyenes egyenletét, majd a két egyenes $M$ metszéspontját, melynek az origótól való távolságnégyzete (koordinátáinak négyzetösszege) a keresett minimumot adja.

$$
\begin{gathered}
e^{\prime} \perp e \Longleftrightarrow m_{e^{\prime}} \cdot m_{e}=-1 \stackrel{m_{e}=-5}{\Longrightarrow} m_{e^{\prime}}=\frac{1}{5} \stackrel{O \in e^{\prime}}{\Longrightarrow} e^{\prime}: y=\frac{1}{5} x \text {, tehát } \\
M\left(x_{M}, y_{M}\right):\left\{\begin{array} { l } 
{ y = - 5 x + 7 } \\
{ y = \frac { 1 } { 5 } x }
\end{array} \Longleftrightarrow \left\{\begin{array}{l}
x_{M}=\frac{35}{26} \\
y_{M}=\frac{7}{26}
\end{array} \Longrightarrow \min \left(x^{2}+y^{2}\right)=\frac{49}{26}\right.\right.
\end{gathered}
$$


Az első feladat esetén arra voltam kiváncsi, hogy a diákoknak eszükbe jut-e az algebrai szélsőérték-feladat geometriai úton való szemléletesebb megoldása az algebrai megoldáshoz képest, illetve hányan próbálkoznak esetleg mindkét módszerrel.

A 23 középiskolás tanuló körül 10 oldotta meg helyesen a feladatot, közülük 3 geometriailag és 1 algebrai és geometriai úton is. A maradék 6 diák csak algebrai úton gondolkodott, sikerrel. A sikertelen feladatmegoldók közül még 3 próbálkozott geometriai módszerrel, de analitikus mértan tudásbeli hiányosságaik miatt, nem jutottak el a helyes szélsőértékig. Még 6 diák jelezte, hogy gondolt geometriai megoldásmódra, de nem indult el. A többi tanuló algebrai úton próbálkozott, sikertelenül.

,Első gondolatom, hogy kifejezem $y$-t, és behelyettesítem a másik kifejezésbe. ... Ez másodfokú lett. Hol is van a parabola minimuma?"

„,Kifejezem $y$-t, behelyettesítem a másik kifejezésbe, majd felhasználom a 9. osztályban tanult képletet. ... Érdekes, hogy negatív szám jön ki minimumnak, holott két szám négyzetösszege a kifejezés. Valamit elszámoltam?"

„Az első egy egyenes egyenlete. Ábrázolom. ... Éppen az origó távolsága kell az egyenestől."

Az egyetemi hallgatók közül 14 diák oldotta meg helyesen a feladatot, közülük 4 geometriailag, és 2 diák mindkét módon. A maradék 8 hallgató csak algebrai úton gondolkodott, sikeresen. A többiek közül 2 diák dolgozott analitikus geometriai módszerrel, a maradék 8 hallgató algebrai eszközökkel a másodfokú kifejezés minimuma helyett annak minimumhelyét számította ki. Még 8 diák fejében megfordult a geometriai megoldás gondolata, de evvel kapcsolatban semmit sem jegyzett le.

„Kifejezem a másodikból az $y$-t, és behelyettesítem az elsőbe. Ez legyen $f(x)$, amit deriválok és meghatározom a szélsőértékeit."

„,Geometriai megoldással próbálkozom. Észrevettem, hogy a feltétel egy egyenes egyenlete, míg a másik kifejezés egy azon mozgó pont és az origó távolságának négyzete. ... A kifejezés minimuma éppen az origónak az egyenestől mért távolsága lesz."

„,Ez egyszerú! Úgy algebrailag, mint geometriai úton megoldható."

A diákok eredményeit összesítő táblázat:

\begin{tabular}{l|c|c} 
& Középiskolás tanuló & Egyetemi hallgató \\
\hline Teljes, helyes megoldás & $10 / 23 \approx 43,48 \%$ & $14 / 24 \approx 58,34 \%$ \\
\hline \hline Ebből geometriai úton & $4 / 23 \approx 17,4 \%$ & $6 / 24 \approx 25 \%$ \\
\hline Geometriai gondolat & $13 / 23 \approx 56,52 \%$ & $16 / 24 \approx 66,67 \%$ \\
\hline \hline Hibás megoldás & $13 / 23 \approx 56,52 \%$ & $10 / 24 \approx 41,66 \%$
\end{tabular}

2. feladat. Határozd meg a $2 x y+2 y z+x z$ kifejezés értékét, ha az $x, y, z>0$ számok teljesítik a $3 x^{2}+4 y^{2}+6 x y=169, \quad 4 y^{2}+z^{2}-2 y z=25, \quad 3 x^{2}+z^{2}+3 x z=144$ összefüggéseket!

Megoldás. A rendszer megoldása, majd a kapott értékek behelyettesítése a meghatározandó kifejezésbe bonyolultnak tünik. Mivel az algebrai megoldásmód nehezen járható út, geometriailag próbálkozunk. Mindhárom egyenlőség hasonlít a koszinusztételben szereplő kifejezésre. Ábrát készítünk, amelyen szakaszhosszként megjelennek a megadott egyenlőségek, majd vizsgáljuk a kiszámítandó kifejezést. 
Az egyenletek az alábbi módon írhatók át:

$$
\begin{gathered}
(\sqrt{3} x)^{2}+(2 y)^{2}-2 \cdot \sqrt{3} x \cdot 2 y \cdot\left(-\frac{\sqrt{3}}{2}\right)=13^{2}, \\
(2 y)^{2}+z^{2}-2 \cdot 2 y \cdot z \cdot\left(\frac{1}{2}\right)=5^{2} \\
(\sqrt{3} x)^{2}+z^{2}-2 \cdot \sqrt{3} x \cdot z \cdot\left(-\frac{\sqrt{3}}{2}\right)=12^{2}
\end{gathered}
$$

Vegyük fel az $O A=\sqrt{3} x, O B=2 y$ és $O C=z$ szakaszokat úgy, hogy $m(\widehat{A O B})=$ $150^{\circ}, m(\widehat{B O C})=60^{\circ}$ és $m(\widehat{C O A})=150^{\circ}$ (5.1. ábra).

Ekkor a koszinusztétel alapján:

$$
\begin{gathered}
A B=\sqrt{3 x^{2}+4 y^{2}+6 x y}=13 \\
B C=\sqrt{4 y^{2}+z^{2}-2 y z}=5 \\
A C=\sqrt{3 x^{2}+z^{2}+3 x z}=12 .
\end{gathered}
$$

Az 5.1. ábrán látható, hogy

$$
T_{A B C}=T_{O A B}+T_{O B C}+T_{O A C}=\frac{\sqrt{3} x y}{2}+\frac{\sqrt{2} y z}{2}+\frac{\sqrt{3} x z}{4} .
$$

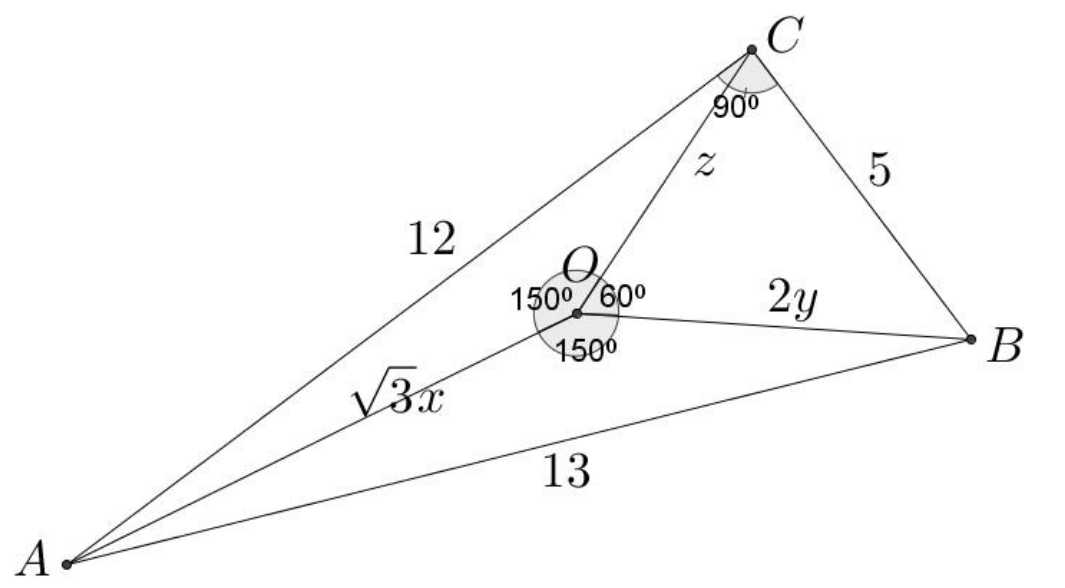

5.1. ábra. Az egyenletrendszer geometriai modellje

Ugyanakkor észrevehető, hogy az 5, 12, 13 pitagoraszi számhármas, így az $A B C$ háromszög derékszögü, tehát $T_{A B C}=\frac{5 \cdot 12}{2}=30$, ahonnan az

$$
\frac{\sqrt{3} x y}{2}+\frac{\sqrt{3} y z}{2}+\frac{\sqrt{3} x z}{4}=30
$$

összefüggéshez jutunk.

Ezt beszorozva $\frac{4}{\sqrt{3}}$-mal éppen a kért kifejezés értékét kapjuk: $2 x y+2 y z+x z=40 \sqrt{3}$. 
Ezzel a feladattal egyértelműen azt szándékoztam mérni, hogy egy algebrai szövegezésü feladat esetén eszükbe jut-e a diákoknak vizuális geometriai modell készítése, majd annak felhasználása a probléma sikeres megoldása érdekében.

A 23 középiskolás diák közül 16 próbálkozott geometriai modell keresésével, közülük 8-nak sikerült tökéletes modellt találnia, és eljutnia a feladat helyes megoldásához. Még 3 tanuló talált használható modellt, de számítási hibák miatt nem a helyes eredményhez jutott, a többi 5 tanulónak nem sikerült használható ábrát alkotnia. A maradék 7 tanuló algebrai úton próbálkozott, természetesen sikertelenül.

A 24 egyetemi hallgatóból 18 jött rá, hogy a koszinusztétel van elrejtve az egyenletekben, és próbált valamilyen geometriai modellt alkotni. Közülük 13 hallgatónak ez sikerült is, de 3 diák számítási hiba miatt nem a tökéletes eredményhez jutott. A többi 5 egyetemista nem talált használható reprezentációt. A maradék 6 hallgató algebrai úton kísérletezett, sikertelenül.

Néhány gondolat a diákok dolgozataiból:

„,Teljes négyzeteket kellene kialakítani első ránézésre. ... Ha kivonom egymásból az egyenleteket, az sem vezet semmire. ... Nem lehet kiküszöbölni egy változót?"

„,Ki kellene fejezni az egyik egyenletből az egyik ismeretlent, pl. z-t, majd a másik kettőbe helyettesíteni. ... De probléma, hogy másodfokúak is szerepelnek ... Így egyre bonyolultabbá válik az egyenletrendszer."

„Geometriai modellt kellene keresni ... a kérésben levő $x y, y z, x z$ szorzatok területek ... az összefüggések szinte teljes négyzetek ... esetleg a koszinusztétel segítene? Nem tudom folytatni ezzel a gondolatmenettel."

„Az összefüggések bal oldala a koszinusztételre emlékeztet. ... Megnézem, hogy milyen szögeket zárnak be a megfelelő oldalak. ... Mivel ezek összege éppen $360^{\circ}$, ezért összerakható a három kicsi háromszögből egy nagy háromszög. ... Kiszámítom a nagy háromszög területét kétféle módon, mert abban a kért kifejezéshez hasonló szorzatok lesznek."

A diákok eredményeit összegző táblázat:

\begin{tabular}{l|c|c} 
& Középiskolás tanuló & Egyetemi hallgató \\
\hline Tökéletes megoldás & $8 / 23 \approx 34,78 \%$ & $10 / 24 \approx 41,67 \%$ \\
\hline \hline Helyes geom. modell & $11 / 23 \approx 47,82 \%$ & $13 / 24 \approx 54,16 \%$ \\
\hline Geometriai gondolat & $16 / 23 \approx 69,56 \%$ & $18 / 24 \approx 75 \%$ \\
\hline \hline Semmilyen modell & $7 / 23 \approx 30,44 \%$ & $6 / 24 \approx 25 \%$
\end{tabular}

3. feladat. Oldd meg a $\left(2^{x}-1\right)^{2}=\log _{2}(\sqrt{x}+1), x \geq 0$ egyenletet!

Megoldás. Az egyenlet két oldalát alaposan megfigyelve látható, hogy a bal oldalon 2-es alapú exponenciális-, míg a jobb oldalon 2-es alapú logaritmusos kifejezés szerepel, ugyanakkor a bal oldal második hatványon jelenik meg, míg a jobb oldal négyzetgyököt tartalmaz, sőt a bal oldalon -1 , a jobb oldalon pedig +1 van a külső függvény argumentumában. Mindezek alapján észrevehető, hogy az egyenlet két oldalán levő kifejezések éppen két olyan függvénynek a leképezési törvényei, amelyek formálisan egymás inverzei.

Mivel az egyenlet a $[0, \infty)$-on értelmezett, tekintsük az

$$
f:[0, \infty) \rightarrow[0, \infty), \quad f(x)=\left(2^{x}-1\right)^{2}
$$


függvényt. (5.2. ábra) Mivel a függvény szigorúan növekvő a $[0, \infty)$-on, ezért injektív. Ugyanakkor az $y=\left(2^{x}-1\right)^{2}$-ből kifejezve az $x$-et, kapjuk, hogy

$$
x=\log _{2}(\sqrt{y}+1) .
$$

Mivel bármilyen $y \in[0, \infty)$ esetén létezik $x=\log _{2}(\sqrt{y}+1) \in[0, \infty)$ úgy, hogy $y=f(x)$, ezért a függvény szürjektív, tehát összességében bijektív, így invertálható, és az inverz függvénye:

$$
f^{-1}:[0, \infty) \rightarrow[0, \infty), \quad f^{-1}(x)=\log _{2}(\sqrt{x}+1) .
$$

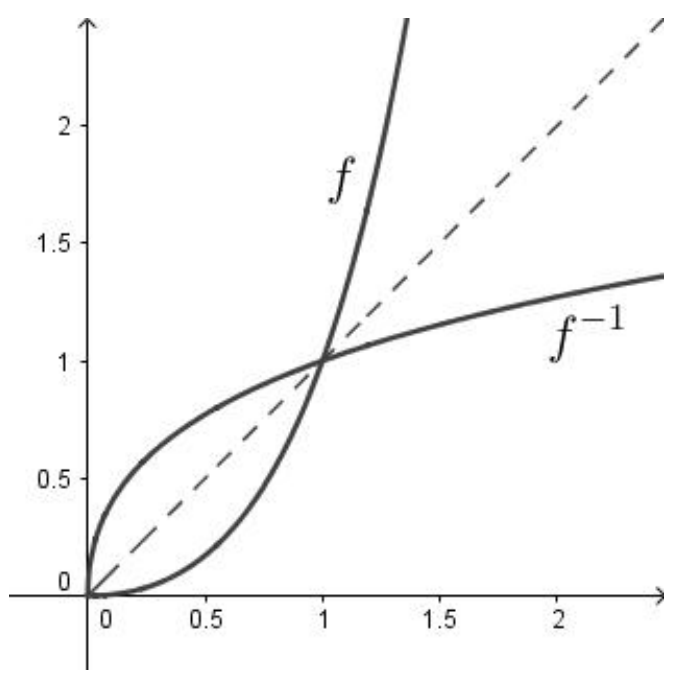

5.2. ábra. Függvény és inverze

Ezt belátva az egyenlet $f(x)=f^{-1}(x)$ alakba írható, és mivel $f$ szigorúan növekvő függvény a $[0, \infty)$-on, ezért

$$
f(x)=f^{-1}(x) \quad \Leftrightarrow \quad f(x)=x \quad \Leftrightarrow \quad\left(2^{x}-1\right)^{2}=x \quad \Leftrightarrow \quad 2^{x}-1=\sqrt{x} .
$$

A kapott egyenlet bal oldala szigorúan konvex, míg a jobb oldala szigorúan konkáv, így az egyenletnek legfeljebb két megoldása lehet. Ezek $x=0$ és $x=1$. (5.2. ábra) Tehát $M=\{0 ; 1\}$.

Megjegyzés. Az egyenlet úgy is megoldható, hogy miután kitaláltuk a két megoldást, igazoljuk, hogy nincs több. Könnyen bizonyítható, hogy a bal oldal másodrendü deriváltja minden nem negatív számra pozitív, tehát ez az oldal szigorúan konvex, míg a jobb oldal másodrendü deriváltja negatív, így az szigorúan konkáv minden nem negatív szám esetén. Tehát a megoldáshalmaz a két kitalált értékből áll.

A feladat kitűzésével azt szándékoztam mérni, hogy a diákok milyen mértékben használnak függvénytani eszközöket egyenletek megoldása során. Konkrétan eszükbe jut-e az egyenlet két oldalán álló kifejezésekről igazolni azok szigorú konvexitását, illetve konkavitását, ezáltal belátva, hogy maximum két megoldás lehet, így azokat ki lehet találni. 
Esetleg észreveszik-e, hogy a két kifejezés egymás inverze, így az egyenlet egyszerübb, könnyebben megoldható alakra hozható.

A 23 középiskolai diákból 19 kitalálta a megoldásokat, de közülük csak 6 tanulónak sikerült teljesen igazolni, hogy nincs más megoldás. Ebből a 6 diákból 4 vette észre, hogy a két oldal egymás inverze, majd hozta egyszerübb alakra az egyenletet, a maradék 2 tanuló némi ábrázolási kísérlet után, differenciálszámításbeli eszközöket alkalmazott az eredeti egyenlet két oldalára.

„A bal oldal másodrendű deriváltja pozitív, a jobb oldalé negatív, ezért maximum két megoldás lehet, és ezek a 0 és az 1. ... Nehezebbnek tünt."

Az egyetemi hallgatók közül hatan semmi érdemlegeset nem kezdtek a feladattal, tehát a 24 diák közül 18 jött rá a megoldásokra. Közülük 14 észrevette, hogy a két oldal egymás inverze, viszont a kapott egyenletet csak 10 hallgató oldotta meg teljes részletességgel, a többi 4 csak közölte, hogy az egyszerübb egyenletnek két megoldása van, de nem hivatkozott az oldalak szigorú konvexitására, illetve konkavitására.

,,Ellenőrzöm, hogy a bal oldal a jobb oldalnak inverze-e. ... Mivel így van, elég megoldani a bal oldal egyenlő $x$ egyenletet. ... Észrevettem, hogy $x=0$ és $x=1$ megoldások, csak nem tudom belátni, hogy más nincs."

A diákok eredményeit összegző táblázat:

\begin{tabular}{l|c|c} 
& Középiskolás tanuló & Egyetemi hallgató \\
\hline Tökéletes megoldás & $6 / 23 \approx 26,1 \%$ & $10 / 24 \approx 41,67 \%$ \\
\hline \hline Megoldás megsejtése & $19 / 23 \approx 82,6 \%$ & $18 / 24 \approx 75 \%$ \\
\hline Inverzek észrevétele & $4 / 23 \approx 17,4 \%$ & $14 / 24 \approx 58,33 \%$ \\
\hline \hline Sejtés sincs & $4 / 23 \approx 17,4 \%$ & $6 / 24 \approx 25 \%$
\end{tabular}

\subsection{A mérések statisztikai összehasonlítása}

Az utómérés eredményei egyértelmüen igazolják a foglalkozások fejlesztő hatását úgy a középiskolások, mint az egyetemi hallgatók körében.

Jól látható, hogy nemcsak a hibátlan, teljes megoldást adók száma növekedett, hanem jelentösen nött azok száma is, akik esetleg figyelmetlenség, gyakorlatlanság, vagy éppen az adott probléma megkövetelte tárgyi tudás hiánya miatt nem oldották meg teljesen a illetö feladatot, de többféle szemszögből megközelitették azt.

Míg az elömérésen a három feladatra összesen 6, illetve 12 hibátlan megoldás született a középiskolások, illetve az egyetemisták körében, addig az utóteszten ezek a számok 24re, illetve 34-re növekedtek. Bár ezek a számok sem túl nagyok az összes feladat számához képest (69, ill. 72), de mindenképpen fejlődést mutatnak.

\begin{tabular}{l|c|c} 
Tökéletes megoldások & Középiskolás tanuló & Egyetemi hallgató \\
\hline Előteszt & $6 / 69 \approx 8,7 \%$ & $12 / 72 \approx 16,67 \%$ \\
\hline Utóteszt & $24 / 69 \approx 34,78 \%$ & $34 / 72 \approx 47,22 \%$
\end{tabular}

Lényegesnek tartom, hogysokkal szembetünőbb a pozitiv változás a feladatok szövegezésétöl eltérö megoldásmód, problémareprezentáció keresésére tett kisérletek számát tekintve. Míg az előteszten a három feladat más reprezentációban történő megoldására a középiskolások körében csupán 4, az egyetemi hallgatók között 9 
sikeres vagy sikertelen kísérlet született összesen, addig az utóteszten ezek a számok 33-ra, illetve 48-ra növekedtek. Ezek a számok egyértelmüen mutatják $\boldsymbol{a}$ foglalkozások pozitiv hatását a diákok gondolkodásában végbement szemléletváltozás, gazdagodás tekintetében.

\begin{tabular}{l|c|c} 
Más reprezentációk & Középiskolás tanuló & Egyetemi hallgató \\
\hline Előteszt & $4 / 69 \approx 5,8 \%$ & $9 / 72 \approx 12,5 \%$ \\
\hline Utóteszt & $33 / 69 \approx 47,83 \%$ & $48 / 72 \approx 66,67 \%$
\end{tabular}

A diákok eredményeinek statisztikai módszerekkel való összehasonlítása érdekében minden tanuló és hallgató mindkét mérésen minden feladatára aszerint, hogy megoldotta, használható sejtése/modellje volt, vagy semmi érdemlegeset sem sikerült kezdenie az adott feladattal, 2, 1, illetve 0 pontot kapott. Azok a diákok, akik legalább két eltérő megoldást is adtak egy problémára plusz 1 pontot kaptak az illető feladatra. Így minden tanuló mindkét teszten 0 és $3 \cdot(2+1)=9$ pont közötti minősítést kapott, melyek gyakoriságát az alábbi táblázat mutatja. A második és harmadik oszlopban az adott pontszámot elért középiskolás tanulók, míg az utolsó két oszlopban az adott pontszámú egyetemi hallgatók száma található.

\begin{tabular}{c||c|c||c|c} 
Pontok & Isk. elő & Isk. utó & Egy. elő & Egy. utó \\
\hline \hline 0 & 8 & 2 & 4 & 3 \\
\hline 1 & 7 & 4 & 8 & 1 \\
\hline 2 & 2 & 5 & 5 & 1 \\
\hline 3 & 5 & 2 & 5 & 4 \\
\hline 4 & 0 & 4 & 1 & 5 \\
\hline 5 & 1 & 0 & 0 & 6 \\
\hline 6 & 0 & 5 & 1 & 3 \\
\hline 7 & 0 & 0 & 0 & 0 \\
\hline 8 & 0 & 1 & 0 & 1 \\
\hline 9 & 0 & 0 & 0 & 0 \\
\hline \hline Összesen & 23 & 23 & 24 & 24
\end{tabular}

Az elő- és utómérés eredményeit az alacsony diáklétszám miatt egymintás párosított $\boldsymbol{T}$-próbával vizsgáltam. Először grafikusan tanulmányoztam a két adatsor normalitását, majd F-próba segítségével ellenőriztem, hogy azok szórása szignifikánsan eltér-e egymástól. Mivel a minták eloszlása nem tért el jelentősen a normál eloszlástól $(\sigma=1,85$, $m=1,85$, ill. $\sigma=2,24, m=3,9)$, és nem mutatható ki szignifikáns különbség az adatsorok szórása között $(p \approx 0,04)$, ezért alkalmazható a páros T-próba. Ez mindkét csoport eredményeinek szignifikáns növekedését mutatja, hiszen a T-próba nullhipotézisének bekövetkezése, miszerint az egyes csoportoknak a két mérés alapján számolt egzakt pontátlaga nem tér el egymástól, kevesebb, mint 0,001 valószínüségü ( $p_{\text {isk. }}=0,0006$, illetve $p_{\text {egy. }}=0,0001$ ), így az alternatív hipotézist kell elfogadnunk, miszerint mindkét csoport esetén a két átlag között szignifikáns változás figyelhetö meg.

Ugyancsak szignifikáns növekedés figyelhető meg a teljesen hibátlan megoldást adók pontszámaira vonatkozóan is, és külön azok pontszámaira is, akik ugyan nem tudták megoldani teljesen a feladatot, de a feladat szövegétől eltérő, már használható reprezentációra váltottak. Így utóbbiak sikertelensége az adott területen levő tárgyi tudásuk, illetve gyakorlatuk hiányának tudható be. 


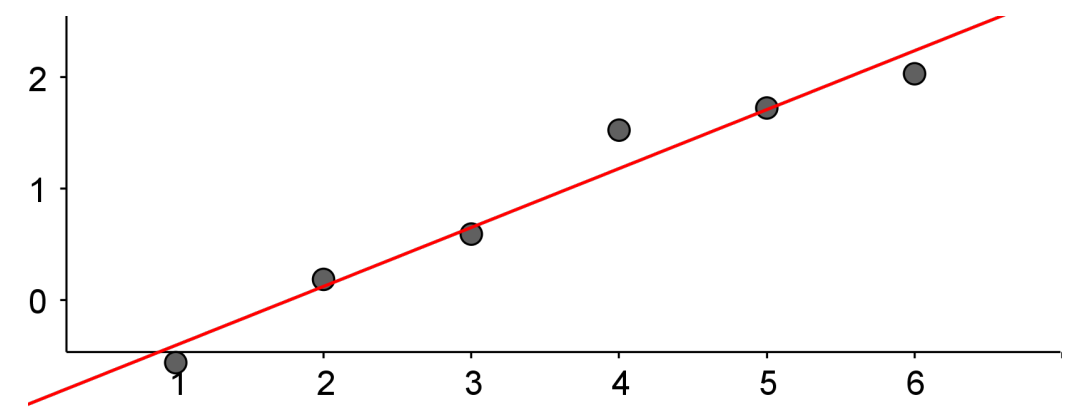

5.3. ábra. Az előmérés kvantilis-kvantilis diagramja $y=0,54 x-1, \quad m=1,85, \quad \sigma=1,85$

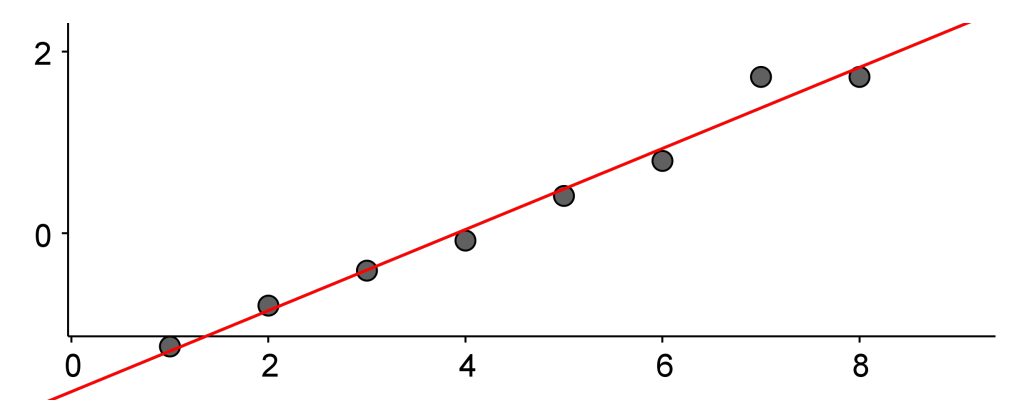

5.4. ábra. Az utómérés kvantilis-kvantilis diagramja

$$
y=0,45 x-1,74, \quad m=3,9, \quad \sigma=2,24
$$




\section{6. fejezet}

\section{Végkövetkeztetések}

\subsection{A hipotézisek igazolása}

A diákok elő- és utómérésen közölt megoldásait összevetve, főleg az egyetemi hallgatók esetén egyértelmü változás figyelhető meg a problémamegoldási folyamatot végigkísérő metakognitív tevékenységük tekintetében is. Mindkét korosztály, de főleg az egyetemi hallgatók dolgozataiból az is kiderül, hogy nagy részük tudatosabban alkalmazza a különböző problémamegoldási heurisztikákat, illetve részletesebben számol be a feladatmegoldási folyamat során felvetődött ötleteiről, próbálkozásairól. Míg az előteszten a többség főleg a feladatok megoldásának valamilyen módon való közlésére fordított nagyobb figyelmet az agyában lezajló mozzanatok írásban való rögzítéséhez képest, addig ez az arány az utóteszten kiegyenlítődött: többen részletesebben közölték háttérgondolataikat, és gyakoribbak lettek a teljes problémamegoldási folyamatot végigkísérő metakognitív beszámolók.

Részlet az egyik egyetemi hallgató utómérésbeli dolgozatából: „,A feladatot látva először eszembe jut, hogy az egyik összefüggésből fejezzem ki az egyik változót, majd helyettesítsem be a másikba. ... A minimumhoz szükségünk van teljes négyzetre, mert arról tudjuk, hogy nem negatív. ... Ez így sikerült is! ... Most eszembe jutott, hogy megpróbálhatnék geometriai modellt készíteni a feladathoz, mert ... Így is sikerült megoldani a feladatot. ... Gondolkodom más megoldáson is, de egyelöre nincs más ötletem."

A fentiek és az előző rész alapján kijelenthető, hogy statisztikailag is alátámasztott az a kijelentés, miszerint a foglalkozásoknak fejlesztő hatása volt, hiszen úgy a középiskolások, mint az egyetemi hallgatók bizonyos problémamegoldó képessége, a feladat szövegétől eltérő, új reprezentációkban való gondolkodási képessége javult, a problémamegoldás során bevethető eszköztáruk bővült.

A kutatás igazolta az elején fölállított hipotéziseimet:

- megfelelő tananyaggal a diákok problémamegoldó képessége fejleszthető

- a diákok tananyagrész-összekapcsoló, -szintetizáló képessége fejleszthető

- a diákok vizuális problémareprezentáció-készítési és transzformációelv alkalmazási képessége fejleszthető

- a problémamegoldási heurisztikák tanítása révén a diákoknak a problémamegoldás során alkalmazható eszköztára bővíthető 


\subsection{Továbblépési lehetőségek}

A problémamegoldási képesség eredményes fejlesztése csak hosszan tartó, szerteágazó és folyamatos munkával valósítható meg. Általános és középiskolás korban ennek legfóbb meghatározó tényezői az iskolai és az otthoni munka. Ezért nagyon fontos, hogy az osztályban való munka, nemcsak matematika, hanem egyéb órán is milyen szellemben zajlik. Emiatt szükségesnek tartom a heurisztikus problémamegoldási stratégiák explicit tanítását és tudatosítását nemcsak a szakkörök diákközönsége körében, hanem osztályszinten, a mindennapokban is. Továbblépésként egyik célom ennek megvalósítása lenne. Másik célom a fejlesztő tevékenységek feladatanyagának - amennyire lehetséges - a mindennapi matematikaóráim tananyagába való beépítése, valamint az érintett témakörök kibővítése más heurisztikus eljárásokra is kitérve.

$\mathrm{Az}$ egyetemi hallgatók körében végzett mérések ugyancsak azt mutatják, hogy számukra is fontos lenne akár egy választható problémamegoldó szeminárium hasonló témakörben.

Remélem, hogy a közel-, illetve távoljövőben mindezek megvalósulhatnak. 


\section{Köszönetnyilvánítás}

Köszönettel tartozom témavezetőmnek, Kosztolányi József tanár úrnak, amiért fölkeltette érdeklődésemet a témakör iránt, majd végig támogatott a munkám során.

Nagy hálával tartozom a kitartó kísérleti alanyaimnak, a diákoknak, akik talán megtapasztalva az együtt gondolkodás örömét, mindenféle más lehetőség helyett az órák utáni köröket választották.

Ugyancsak hálás vagyok András Szilárdnak, aki nemcsak figyelmes és kritikus olvasója volt a dolgozatnak, hanem egész eddigi tanári tevékenységem egyik meghatározója.

Köszönöm Darvas Tamásnak az angol fordításban nyújtott segítségét és Róth Ágostonnak az adatok statisztikai feldolgozására vonatkozó útbaigazításait.

Végül köszönöm mindenkinek, aki valamilyen módon hozzájárult, hogy a dolgozat megszülethessen. 


\section{Összefoglalás}

A matematikatanítás egyik legfontosabb célja a gondolkodásra nevelés, amely problémamegoldás és a matematika felfedeztető módon való tanításával valósítható meg. Korábbi kutatások [29], [17], [24] bizonyítják, hogy ebben óriási szerepet játszik az általános heurisztikus eljárások ismerete, ugyanakkor arra is rávilágítanak, hogy a különböző heurisztikák alkalmazási képessége különböző mértékben fejleszthető. Nehezebben alakítható ki például a problémának az eredeti kontextustól eltérő, más területen való reprezentálásának, különböző nézőpontból való tudatos megközelítésének gondolata. Ez a megfigyelés sarkallt arra, hogy olyan problémák megoldása révén, melyek sikeres megoldása az eredeti megfogalmazástól eltérö, más területen való okoskodást igényel, a reprezentációváltás mint problémamegoldási stratégia taníthatóságával foglalkozzak. A kutatásom során középiskolás diákok és matematika szakos egyetemi hallgatók problémamegoldási képességét és célirányos fejlesztésének lehetőségeit vizsgáltam.

Céljaim a következők voltak:

1. a matematikai gondolkodás, problémamegoldás elméleti hátterének áttekintése

2. a diákok problémamegoldási képességének mérése; ezen belül hangsúlyosan:

- vizuális problémareprezentáció-készítési, elemzési és a problémamegoldási folyamatban való sikeres alkalmazási képesség mérése

- a transzformációelv mint általános heurisztikus eljárás alkalmazási képességének mérése

- tananyagrész-összekapcsoló, -szintetizáló képesség mérése

3. célzottan a fenti képességeket fejlesztő tananyag kidolgozása és alkalmazása

4. a fejlesztés elején fölállított hipotéziseim igazolása:

- megfelelő tananyaggal a diákok problémamegoldó képessége fejleszthető:

- a diákok tananyagrész-összekapcsoló, -szintetizáló képessége fejleszthető

- a diákok vizuális problémareprezentáció-készítési és transzformációelv alkalmazási képessége fejleszthető

- a problémamegoldási heurisztikák explicit tanítása révén a diákoknak a problémamegoldás során felhasználható eszköztára bővíthető 
A kutatást a fejlesztés kereteinek kijelölése végett a megfelelő matematikadidaktikai szakirodalom áttanulmányozásával kezdtem. A matematikatanítás különböző célrendszereinek [4], [39], [37] áttekintése után részletesen vizsgáltam a problémamegoldó gondolkodás szerkezetét: a problémamegoldás folyamatát [10],[25],[36],[18], az abban különösen hasznos heurisztikus eljárásokat [26], [30], valamint az ezeket végigkísérö metakognitív elemeket [19]. A folyamat szerkezetének jobb megértése érdekében kitértem a matematikai gondolkodás természetének néhány aspektusára: a matematikai fogalmak külső és belső reprezentációs hálózatára [8], [13], a vizuális reprezentációk szerepére [9], [28], a kritikai, illetve kreatív gondolkodásmód jellemzőire [16], [23], [35], majd a problémamegoldó gondolkodás komplex kognitív modelljére [33]. Végül a problémamegoldó képesség fejlesztésének lehetőségeit tekintettem át, kitérve úgy a kognitív [9], [5], [37], mint a metakognitív [11] és affektív [32] elemekre.

A kutatás kezdetén úgy a középiskolás tanulók, mint az egyetemi hallgatók előmérésen vettek részt. A diákoknak másfél óra alatt három nem szokványos probléma részletes megoldását kellett kidolgozniuk, és ezzel párhuzamosan a megoldás során felmerülő gondolataikat, érzéseiket leírniuk.

Célom annak fölmérése volt, hogy a kísérletben részt vevő diákok

- milyen általános problémamegoldási heurisztikákat ismernek,

- bizonyos problémák esetén próbálkoznak-e a feladat kijelentésétől eltérő, más reprezentációkban való okoskodással

- mennyire tudják a matematika különböző területeiről származó tudásukat a feladatmegoldás során mozgósítani, képesek-e a különböző jellegü ötleteiket ötvözni,

- problémamegoldás közben milyen metakognitív gondolatok jelennek meg, illetve milyen érzelmek játszódnak le bennük, és mennyire tudják ezeket közölni.

A felmérésnek egy másik célja a középiskolás és egyetemista csoport eredményeinek az összehasonlítása, az esetleges különbségekre való rávilágítás volt.

Az eredmények alapján elmondható, hogy

- mindkét diákcsoport eszköztára meglehetősen hiányos a nem rutinszerű matematikai problémák megoldásában,

- sok esetben még a feladat megoldására (eredményére) vonatkozó valamilyen sejtés megfogalmazása is nehézséget jelent,

- alig fordul elő a feladat kijelentésétől eltérő, más reprezentációban vagy többféle reprezentációban való okoskodás gondolata,

- a diákok feladatmegoldás közbeni metakognitív tevékenysége igen hiányos, illetve nehezen tudják írásban megfogalmazni az ilyen jellegü gondolataikat,

- az egyetemi hallgatók eredményei csak nagyon kevéssel jobbak a középiskolás tanulók eredményeinél. 
Az előmérés eredményei határozták meg a fejlesztés fö irányvonalait, melyek a következők voltak:

- a problémamegoldás lépéseinek tudatosítása

- általános heurisztikus eljárások, stratégiák tanítása problémamegoldás útján

- az analógiákban való gondolkodás fejlesztése

- kísérletezés alapján történő sejtések megfogalmazásának elősegítése, gyakorlása

- különböző reprezentációkban való gondolkodásra nevelés a feladat szövegezésének mélyrehatóbb vizsgálata által; az „árulkodó jelek” megfigyelésére való érzékenység kialakítása és fejlesztése

- az egyes objektumok struktúráját legjobban szemléltető reprezentációk felismerése

- a transzformációelv mint általános heurisztikus eljárás alkalmazása

• különböző vizuális problémareprezentációk készítése, elemzése

- új problémák megfogalmazása egy adott modellen történő módosítással

- többféle megoldási lehetőség keresése

A fenti céloknak megfelelően a fejlesztés három hónapon keresztül heti másfél órás szakköri foglalkozások formájában zajlott. A diákok óra elején megkapták az aznapi feladatokat anélkül, hogy tudták volna azokról, hogy milyen témakörbe tartoznak, milyen stratégia fejlesztésére valók. Igyekeztem a diákokat önálló felfedezésekre buzdítani, így a 2-3 fös csoportok munkáját segítő kérdések formájában csak akkor befolyásoltam, ha azt ők igényelték. Ösztönöztem a diákokat az egyes feladatok többféle irányból való megközelítésére, különböző megoldási módszerek keresésére, esetleg azok ötvözésére. Minden olyan probléma esetén, ahol többféle megoldás is született, megbeszéltük, hogy melyik hatékonyabb, eredményesebb, melyik tükrözi jobban az adott probléma szerkezetét. Végül bátorítottam a diákokat, hogy maguk is fogalmazzanak meg hasonló szerkezetü problémákat. A feldolgozott témakörök az alábbi három fő stratégia köré szerveződtek:

1. Algebrai kijelentés - geometriai megoldás

Szintetikus, analitikus és trigonometrikus megoldásmódok

2. Geometriai kijelentés - algebrai megoldás

A Descartes-féle koordináta-rendszer felhasználása

A Gauss-féle komplex számsík alkalmazása

3. Alkalmas függvény bevezetése

Elemi függvények tulajdonságainak felhasználása

A matematikai analízis elemeinek alkalmazása 
Mindhárom témakörbe illeszkedő problémák sikeres vagy legalábbis hatékony megoldása a feladat szövegezésétől eltérő más reprezentációban való gondolkodást igényelt. Természetesen ez a stratégiai jellegü ötlet a különböző témakörökhöz tartozó problémák esetén különbözőképpen születhet meg.

$\mathrm{Az}$ első stratégiát algebrai szövegezésű feladatok, konkrétan egyenletek, egyenlőtlenségek, egyenletrendszerek és szélsőérték-problémák megoldásának, különböző algebrai összefüggések bizonyításának a tanórákon megszokott tipikus módszerektől eltérő, más szemléletmódja révén kívántam bemutatni, elmélyíteni.

Célom ezeknek a problémáknak a tárgyalásával az volt, hogy a diákok algebrai szövegezésü feladat láttán is képesek legyenek aktivizálni mértantudásukat, geometriai szemszögből is képesek legyenek tanulmányozni egy algebrai probléma szerkezetét, képesek legyenek akár a feladatnak megfelelő vizuális geometriai modell alkotására és annak tanulmányozására. Itt olyan modellek készítésével foglalkoztunk, amelyek valamilyen algebrai szövegezésű probléma szintetikus-, analitikus-, vektorgeometriai vagy trigonometriai megoldásmódját teszi lehetővé. A diákok belátták, hogy a feladatok többségénél, ha található a geometria egyik területén való tárgyalásmódot lehetővé tevő modell, akkor az kis módosítással más területen való okoskodást elősegítő modellé alakítható. Minden esetben elemeztük a különböző modellek elönyeit és hátrányait, majd a diákok igyekeztek hasonló problémákat szerkeszteni.

A második stratégia szemléletében az előzőnek éppen a fordítottja: geometriai szövegezésü feladatok algebrai eszközökkel való megközelítése.

Célom az ide tartozó problémakör tanításával annak illusztrálása volt, hogy teljesen geometriai kijelentésü feladatok sikeres megoldása néha részben, vagy akár teljes egészében algebrai eszköztár bevetését kívánja, hiszen azzal egyszerübben és hatékonyabban kezelhetők az objektumok közötti összefüggések. Itt két nagyon hasznos stratégiai jellegü ötletet tárgyaltunk: áttérés a Descartes-féle koordináta-rendszerbe vagy a Gauss-féle komplex számsíkra. Minden feladat esetén részletesen megbeszéltük, hogy mikor, milyen az adatokra vonatkozó viszony esetén hatékonyabb az egyik vagy a másik eszköz használata. Például objektumok forgatását igénylő probléma esetén a komplex számsík bevezetése célravezetőbb. Tapasztalataim szerint az ebbe az irányba történő váltás könnyebben ment a diákoknak, mint az előző problémakör esetén tárgyalt fordított irány.

Az utolsó stratégia bizonyos problémák megoldását jelentősen elősegítő alkalmas függvény megtalálását és annak valamilyen tulajdonságának felhasználását kívánta. Nagyrészt egyenletek, egyenlőtlenségek és egyenletrendszerek nem algoritmikus megoldásával, illetve különböző geometriai szélsőértékek keresésével szemléltettem ezt. Különböző egyszerűnek tűnő egyenletek megoldása(i) gyakran kitalálható(k), viszont az unicitás bizonyítása elemi eszközökkel már nem mindig lehetséges. Ilyenkor valamilyen alkalmas függvény bevezetése és értelmezési tartományának, ill. értékkészletének tanulmányozása vagy a függvény injektív, monoton, konvex/konkáv tulajdonságának felhasználása lehet eredményes. Geometriai szélsőérték-problémák esetén a megfelelő elemi becslés okozhat nehézséget, ám ez gyakran valamilyen alkalmas függvény korlátosságának belátásával vagy éppen szélsőértékeinek kiszámításával elkerülhető. Ezek mellett különböző eleminek tűnő összegeket tanulmányoztunk, melyek hatékony kiszámítása valamilyen alkalmas függvény deriválása vagy éppen integrálása segítségével oldható meg. 
Célom ennek a stratégiának a bemutatásával annak tudatosítása volt a diákokban, hogy a romániai középiskolai tananyag központi elemének számító függvény fogalma és az arra épülő matematikai analízis nem elszigetelt tudományterület, hanem egy lehetséges és gyakran nagyon hasznos eszköz az problémamegoldás során. Lássák a diákok, hogy a matematika különböző területeinek az összekapcsolása hasznos és sok esetben nélkülözhetetlen a nem sablonszerü problémák eredményes megoldása érdekében.

A fejlesztő foglalkozássorozatot utómérés követte. A diákoknak az előteszthez hasonlóan 90 perc alatt három, számukra ismeretlen problémát kellett minél részletesebben és akár többféle módszerrel megoldaniuk. A dolgozatlapot függőlegesen kettéosztva bal oldara került a problémák megoldásának kidolgozása, míg ezzel párhuzamosan a jobb oldalon a diákok gondolataikról, metakognitív tevékenységükről számoltak be.

A feladatok a következő képességek mérésére szolgáltak:

- kísérletezés alapján történő sejtések megfogalmazása, majd azok bizonyítása

- különböző reprezentációkban való gondolkodás, vizuális problémareprezentációk alkotása, elemzése

- a transzformációelv mint általános heurisztikus eljárás alkalmazása

Emellett a problémamegoldási folyamatot végigkísérő tudatos metakognitív tevékenység változására, fejlődésére is kíváncsi voltam.

Az utóteszt eredményei alapján elmondható, hogy mindkét diákcsoport problémamegoldó eszköztára gazdagodott, ugyanakkor a diákok bátrabban próbálkoztak eddig ismeretlen, új módszerek alkalmazásával. Mindhárom feladat esetén nőtt a teljesen helyes megoldást adók száma, sőt voltak, akik többféle megoldást is adtak egy-egy problémára. Ugyanakkor jelentősen változott pozitív irányban azok száma is, akik ugyan nem tudták megoldani a feladatot, de annak különböző reprezentációival próbálkoztak. A diákok feladatmegoldás közbeni metakognitív tevékenysége is hangsúlyosan javult, többen részletesen beszámoltak az ilyen jellegü háttérgondolataikról.

A foglalkozások fejlesztő hatását a két mérés statisztikai összehasonlítása révén elemeztem. Minden diák mindkét mérésen minden feladatára aszerint, hogy megoldotta, használható sejtése/modellje volt, vagy semmi érdemlegeset sem sikerült kezdenie az adott feladattal, 2, 1, illetve 0 pontot kapott. Azok a diákok, akik legalább két eltérő megoldást is adtak egy problémára plusz 1 pontot kaptak az illető feladatra. Így minden diák mindkét teszten 0 és $3 \cdot(2+1)=9$ pont közötti minősítést kapott. Az adatok viszonylag kis száma miatt, és mivel az elő- és utómérés eredményei nem térnek el jelentősen a normál eloszlástól, valamint az azokra végrehajtott F-próba szerint a két adatsor szórása között nem mutatható ki szignifikáns eltérés, ezért a két adatsor átlagának szignifikáns eltérését egymintás párosított T-próbával ellenőriztem. Ez mindkét csoport eredményeinek szignifikáns növekedését mutatta, sőt ugyancsak szignifikáns növekedés figyelhető meg a teljesen hibátlan megoldást adók pontszámaira vonatkozóan is, és külön azok pontszámaira is, akik ugyan nem tudták megoldani teljesen a feladatot, de a probléma szövegétől eltérő, más használható reprezentációra váltottak. Így utóbbiak sikertelensége az adott területen levő tárgyi tudásuk, illetve gyakorlatuk hiányának tudható be. Ugyanakkor a diákok elő- és utómérésen közölt megoldásait összevetve, főleg az egyetemi hallgatók esetén egyértelmű változás figyelhető meg a problémamegoldási folyamatot végigkísérő metakognitív tevékenységük tekintetében is. 
Tehát statisztikailag is alátámasztott a foglalkozások fejlesztő hatása, így a kutatás igazolta a elején fölállított hipotéziseimet, miszerint

- megfelelő tananyaggal a diákok problémamegoldó képessége fejleszthető

- a diákok tananyagrész-összekapcsoló, -szintetizáló képessége fejleszthető

- a diákok vizuális problémareprezentáció-készítési és transzformációelv alkalmazási képessége fejleszthető

- a problémamegoldási heurisztikák tanítása révén a diákoknak a problémamegoldás során alkalmazható eszköztára bővíthető

Mivel a problémamegoldási képesség további fejlesztése csak hosszan tartó, szerteágazó és folyamatos munkával valósítható meg, ezért szükségesnek tartom a heurisztikus problémamegoldási stratégiák explicit tanítását és tudatosítását nemcsak a matematika szakkörök diákközönsége számára, hanem osztályszinten a mindennapokban is. Továbblépésként egyik célom ennek megvalósítása lenne. Másik célom a fejlesztő tevékenységek feladatanyagának a mindennapi matematikaóráim tananyagába való beépítése, kibővítve az érintett témaköröket kitérve más heurisztikus eljárásokra is. 


\section{Summary}

One of the main goals of mathematics education, is teaching how to think correctly, which can be realized by problem solving and use of exploratory teaching methods. According to earlier research [29], [17], [24], knowledge of heuristic methods plays an important role in this learning process. They also show that related skills can be developed in varying capacity. As a representative example, it is known that problem solving via change of representation, a method in which the context of the problem is significantly altered, is a very difficult skill to master. This observation led me to investigate the extent to which it is possible to teach change of representation as an effective problem solving strategy. As part of my research, I worked with a group of high school students and a group of undergraduate students, to see if these skills can be taught effectively.

My goals were as follows:

1. overview of the theoretical background of mathematical thinking and problem solving

2. measuring the problem solving skills of students. More precisely I focused on the following:

- the success rate of visual representation in solving problems

- the effectiveness of the transformation principle as problem solving strategy

- ability to connect and synthesize different parts of the curriculum

3. to introduce a curriculum that helps develop the above mentioned skills

4. to prove my hypothesis, formulated before my study:

- with the appropriate curriculum one can develop the problem solving skills of the students. More precisely:

- the ability of the students to connect and synthesize different parts of the curriculum can be increased

- the ability of the students to use visual representation and the transformation principle successfully can be increased.

- by explicitly teaching specific problem solving heuristics, the available problem solving skill set of students can be significantly increased. 
Before carrying out my study I made an assessment of the current mathematics education literature regarding the goals of my project. After an overview of the goals of mathematics education [4], [39], [37], I examined in detail the structure of problem solving: the process of problem solving [10],[25],[36],[18], the most useful heuristic methods [26], [30], and the related metacognitive elements [19]. For sake of better understanding, I spent time with a few aspects of mathematical thinking: the inner and outer network of mathematical concepts [8], [13], the role of visual representation [9], [28], the features of critical and creative thinking [16], [23], [35], and the complex cognitive model of problem solving [33]. Lastly, I did an overview of the possibilities regarding development of problem solving skills, with focus on cognitive [9], [5], [37], metacognitive [11] and affective [32] elements.

At the beginning of my research, the high school and undergraduate students participated in a preliminary assessment. They were given three unusual problems to solve within one and a half hours, and they were also instructed to write down their feelings and thoughts parallel to solving the problems.

My goal was to measure the following:

- what problem solving strategies are the students familiar with

- are they trying to use change of representation in their approach to solving the problems

- to what extent are the students capable to use knowledge from different parts of mathematics and to combine different ideas

- the presence of metacognitive thoughts during the problem solving process, what emotions do they feel, and how can they communicate these

As an additional goal of the assessment, I planned to compare the results of the high school and undergraduate students.

Based on the outcome I can say the following:

- both groups were lacking skills in solving non-routine mathematical problems

- in most cases, even guessing or conjecturing the right solution was deemed too difficult

- speculation regarding change of representation appeared in only few cases

- metacognitive activity is rarely present during problem solving, and communication of such activity seems very difficult

- the results of undergraduate students were only slightly better compared to the results of the high school students

Based on this assessment I determined the following main lines of skill development:

- learning the steps of problems solving consciously

- teaching the basic heuristic procedures and strategies via problem solving 
- developing thinking in terms of analogies

- using experimentation to make conjectures

- teach them how to change representation, and the ability recognize hints in the wording of the problem that indicates the correct usage of this method

- to recognize what representation sheds more light on the structure of mathematical objects

- the usage of the transformation principle as basic heuristic strategy

- analysis of different visual representations for a problem

- coming up with new problems by modifying a given model

- finding different solutions for the same problem

In accordance with my goals, the development of skills took place over a three month period. I met with the students every week for a session of one and a half hours. Before every session, the students received a worksheet with problems up for discussion. I encouraged individual work within groups of 2-3 students. I only interfered with their work when I was asked specifically to do so. I put emphasis on trying to give multiple solutions with different methods to the same problems. When different solutions were found, we discussed the effectiveness of each method. At last, I asked the students to formulate problems that can be solved by the same method. The thematics of each meeting revolved mostly around three main strategies:

1. Algebraic formulation - geometric solution solutions involving classical, analytic and trigonometric methods

2. Geometric formulation - algebraic solution usage of Cartesian coordinates usage of the Gaussian complex plane

3. Introduction of appropriate functions

usage of properties of basic functions usage of function calculus

Solving the given problems required finding an appropriate context that was different from the wording of the problem. The corresponding strategy of course was different given the different nature of each problem, corresponding to the above thematics.

The first strategy revolved around approaching algebraic equations, inequalities, systems of equations and extremum problems using methods that were different from the usual curriculum.

My goal was to make the students use their geometric skill set to solve these problems that were worded using algebra, effectively combining different themes in the standard 
curriculum that are considered far apart from each other. We worked with geometric models that allowed students to find solutions via trigonometry, as well as analytic, classical and vector geometry. The students realized that using geometric models it is possible to solve a much wider class of problems than we discussed, and I encouraged them to formulate such problems on their own. In all cases we discussed the effectiveness of our strategies.

The second strategy was the opposite of the previous one. Given a problem with geometric wording, try to find a solution using algebra.

My goal was to illustrate that problems that appear in a geometric context can be partially of completely solved using algebraic methods, as these allow to discuss the relation between the different objects more precisely. We highlighted two methods specifically: usage of Cartesian coordinates, or complex numbers from the Gaussian plane. For each problem we discussed the specific hints in wording that suggest one geometric approach of the other. For example, problems that involve rotation suggest a treatment using complex numbers. According to my experiences the students found it easier to use this second strategy than the first strategy discussed above.

The last strategy involved solution of problems using the identification of an appropriate function, and studying its properties. We mostly tried to find non-algorithmic solutions to equations, inequalities, systems of equations and geometric extremum problems. Solutions to such problems can often be guessed, but showing uniqueness often requires a more involved analysis. This is often carried out by introducing an appropriate function, studying its domain of definition and image, injectivity, surjectivity, monotonicity and convexity. In case of geometric extremum problems, guessing a basic estimate can be often difficult, however this can be made easier with the introduction of an appropriate function and proving its boundedness. In addition to the above, we studied formulas involving sums. Such sums can be often computed after differentiating or integrating an appropriate function.

My goal with this strategy was to show the students that central element in the Romanian mathematical curriculum, the calculus of functions, is not as isolated as they might think, and it can be used as an effective strategy in solving a vast set of problems. Let the students see that combining different parts of mathematics is useful, and often indispensable in solving non-routine problems.

We followed up our activities with a final assessment. Similar to the preliminary assessment, students had 90 minutes at their disposal to solve three problems. Each sheet was split into two parts. On the left hand side the students had to write up their solution. On the right hand side I asked the students to document their thoughts and metacognitive activity.

The goal was to measure the following:

- the ability to formulate conjectures using experimentation, and later proving these conjectures

- the ability to use different representation in thinking, creating and analyzing visual representations

- the ability to use the transformation principle as a heuristic procedure 
Besides the above, I was also curious to learn if there was any change in metacognitive activity compared to the preliminary assessment.

Based on the tests we can say that both groups of students increased their problem solving skill set significantly, and they had more confidence in using different, previously not seen methods in their approach. In case of all three problems there were more complete solutions, moreover some students gave more than one solution to the same problem. Also, there was significant increase in the number of students that could not completely solve a problem, but were able to find an effective approach using a different representation. There was also increased metacognitive activity, and many students were able to effectively communicate their background thought process in much detail.

The effectiveness of our activities was measured by statistical comparison of the two assessments. In case of partial or complete solution, students received 1 or 2 points for each problem. If at least two solutions were given, a student received 3 points for the problem. Consequently, the total score of each student was between 0 and $3 \cdot(2+1)=9$ points. Since sample size was small, and the F-test indicated no significant difference in the variance of scores for each of the assessments, I compared the significant difference in the average scores using a paired samples T-test. This indicated a significant increase in score for both group of students. Moreover, I also saw significant increase in number of complete solutions, and number of partial solutions were the correct visual representation was identified. Absence of complete solution in these latter cases is likely due to lack of specific content knowledge. Comparing the problem solutions of the two assessments, I noticed a clear difference in metacognitive activity as well, especially noticeable in the case of the undergraduate students.

Consequently, the marked positive effect of my activities was proved by statistical methods, and the research proved my preliminary hypothesis according to which

- with the appropriate curriculum it is possible to develop the problem solving skills of students

- it is possible to increase the skill of students to connect relatively distant parts of the curriculum

- students can effectively learn how to use visual representation and the transformation principle

- by teaching problem solving heuristics, it is possible to significantly increase the problem solving skill set of students.

The development of problem solving strategies can only be accomplished by a long and persistent process. As a result, I think it is important to teach problem solving heuristics to students explicitly, not only during material specific workshops, but also during regular classroom hours on a daily basis. This would be one of my goals in the next step of my research. As another goal, I would like to integrate the problems of my activities into the classroom setting, by possibly extending the thematics with additional topics. 


\section{Irodalomjegyzék}

[1] Ambrus András: A problémamegoldás tanításának elméleti alapjai, Új Pedagógiai Szemle, 10 (2002), 157-169.

[2] Ambrus András: A konkrét és vizuális reprezentációk használatának szükségessége az iskolai matematikaoktatásban, Magiszter, 3 (2003), 61-75.

[3] Ambrus András: Bevezetés a matematika-didaktikába, ELTE Eötvös Kiadó, Budapest, 2004

[4] Bloom, B. S., Engelhart, M. D., Furst, E. J., Hill, W. H., Krathwohl, D. R.: Taxonomy of educational objectives: The classification of educational goals, David McKay Company, New York, 1956

[5] Claus, H. J.: Einführung in die Didaktik der Mathematik, Wissenschaftliches Buchgesellschaft, Darmstadt, 1989

[6] Csíkos Cs., Szitányi J., Kelemen R.: Vizuális reprezentációk szerepe a matematikai problémamegoldásban. Egy 3. osztályos tanunlók körében végzett fejlesztő kísérlet eredményei, Magyar Pedagógia, 110/2 (2010), 149-166.

[7] Dörner, D.: Emotion und problemlösendes Denken. In. Mandl, H., Huber, G.: Emotion und Kognition, München, 1983

[8] Devlin, Keith: The Math Gene - How Mathematical Thinking Evolved And Why Numbers Are Like Gossip, Basic Books, 2000

[9] Dreyfus, T.: A matematikai gondolkodás különbözö oldalairól. In Sternberg, R., BenZeev, T.: A matematikai gondolkodás természete, Vince kiadó, Budapest, 1998

[10] Fisher, R.: Hogyan tanitsuk gyermekeinket gondolkodni?, Müszaki könyvkiadó, Budapest, 2002

[11] Garofalo, J., Lester, F. K.: Metacognition, cognitiv monitoring, and mathematical performance, Jornal for Research in Mathematics Education, 16/3, 1985, 163-176.

[12] Gick, M. L., Holyoak, K. J.: Schema induction and analogical transfer, Cognitive Psychology, 15 (1983), 1-38.

[13] Goldin, G. A., Kaput, J.: A joint perspective on the idea of representation in learning and doing mathematics. In Steffe, L., Nesher, P., Cobb, P., Goldin, G., Greer, B.: Theories of mathematical learning, Erlbaum, Hillsdale, 1996 
[14] Goldin, G. A.: Affective Pathways and Representation in Mathematical Problem Solving, Mathematical Thinking and Learning, $2 / 3$ (2000), 209-219.

[15] Goldin, G. A.: Representational Systems, Learning, and Problem Solving in Mathematics, Journal of Mathematical Behavior, 17/3 (1998), 137-165.

[16] Hámori József: Az emberi agy asszimmetriái, Dialog Campus, Budapest, 1999

[17] Kosztolányi József: A problémamegoldási stratégiák tanitásáról, PhD értekezés, Debreceni Egyetem, 2006

[18] Lénárd Ferenc: A problémamegoldó gondolkodás, Gondolat kiadó, Budapest, 1985

[19] Lester, F. K.: Methodological Consideration in Research on Mathematical ProblemSolving Instruction. In Silver, E. A.: Teaching and Learning Mathematical Problem Solving: Multiple Research Perspectives, Routledge, New York and London, 2009

[20] Lipman, M.: Thinking in Education, Cambridge University Press, Cambridge and New York, 2003

[21] Mayer, R., Hegarty, M.: A matematikai problémák megértésének folyamata. In Sternberg, R., Ben-Zeev, T.: A matematikai gondolkodás természete, Vince kiadó, Budapest, 1998

[22] Molnár Gyöngyvér: Az életszerü feladathelyzetekben történö problémamegoldás viszgálata, Magyar Pedagógia, 101/3 (2001), 347-373.

[23] Paivio, A., Begg, I.: Psychology of language, Prentice Hall, New Jersey, 1981

[24] Pintér Klára: A matematikai problémamegoldás és problémaalkotás tanitásáról, $\mathrm{PhD}$ értekezés, Szegedi Tudományegyetem, 2012

[25] Pólya György: A gondolkodás iskolája, Akkord Kiadó, Budapest, 2000

[26] Pólya György: A problémamegoldás iskolája I-II., Tankönyvkiadó, Budapest, 1967, 1968

[27] Pólya György: A matematikai gondolkodás müvészete I-II., Gondolat Könyvkiadó, Budapest, 1988

[28] Presmeg, N.: Visualisation in high-school mathematics, For the Learning of Mathematics, 6 (1986), 42-46.

[29] Schoenfeld, Alan H.: Problem Solving in the Mathematics Curriculum, MAA Notes, 1983

[30] Schoenfeld, Alan H.: Mathematical Problem Solving, Academic Press, INC., New York, 1985

[31] Schoenfeld, Alan H.: Learning to Think Mathematically: Problem Solving, Metacognition, and Sense-Making in Mathematics. In Grouws, D.: Handbook for Research on Mathematics Teaching and Learning, MacMillan, New York, 1992 
[32] Skinner, E. A., Belmont, M. J.: Motivation in the classroom: Reciprocal effects of teacher behavior and student engagement across the school year, Journal of Educational Psychology, 85/4 (1993), 571-581.

[33] Tóth Péter: A problémamegoldó gondolkodás fejlesztésének módszertana, http://www.fovpi.hu/data/cms42055/tppmgondolkodas.pdf

[34] Vincze Szilvia: A matematikai képesség összetevőinek vizsgálata és kapcsolata az intelligenciával, Magyar Pedagógia, 103/2 (2003), 229-261.

[35] Wachsmuth, I.: Two modes of thinking - also relavant for the learning of mathematics. In For the learning of mathematics, 2 (1981), 38-45.

[36] Wilson, J. W., Fernandez, M. L., Hadaway, N.: Mathematical Problem Solving. In Wilson, P. S. Research Ideas for the Classroom: High School Mathematics, MacMillan, New York, 1993

[37] Wittmann, Erich Ch.: Grundfragen des Mathematikunterrichts, Vieweg+Teubner Verlag, 1981

[38] Woodward, J., Beckmann, S., Driscoll, M., Franke, M., Herzig, P., Jitendra, A., Koedinger, K. R., Ogbuehi, P.: Improving mathematical problem solving in grades 4 through 8: A practice guide, National Center for Education Evaluation and Regional Assistance, Institute of Education Sciences, Washington DC., 2012

[39] Zech, F.: Grundkurs Mathematikdidaktik, Belts Verlag, Basel, 1989

\section{Feladatgyüjtemények}

[40] András Szilárd: A matematika tanítása, Státus Kiadó, Csíkszereda, 2009

[41] Ábrahám Gábor: Nevezetes egyenlőtlenségek, Mozaik Kiadó, Szeged, 1995

[42] Bogdán Zoltán: Matematika feladatok, ötletek, megoldások középiskolásoknak, egyetemistáknak, Nemzeti Tankönyvkiadó, Budapest, 1995

[43] Andrică Dorin şi col.: Geometrie pentru grupele de performanţă, Editura Studia, Cluj-Napoca, 2010

[44] Czapáry Endre, Czapáry Endréné, Csete Lajos, Hegyi Györgyné, Irányiné Harró Ágota, Morvai Éva, Reiman István: Matematika gyakorló és érettségire felkészítő feladatgyüjtemény III., Nemzedékek Tudása Tankönyvkiadó, Budapest, 2005

[45] Engel, Arthur: Probleme de matematică - Strategii de rezolvare, Editura Gil, 2006

[46] Olosz Ferenc: Egyenletek I-II., Zalamat Alapítvány, Nagykanizsa, 2012

[47] Petruşel Adrian şi col.: Algebră pentru grupele de performanţă, Editura Studia, ClujNapoca, 2010 
[48] Pop Vasile, Lupşor Viorel şi col.: Matematică pentru grupele de performanţă, clasa a IX-a, Editura Dacia, Cluj-Napoca, 2004

[49] Pop Vasile, Lupşor Viorel şi col.: Matematică pentru grupele de performanţă. Exerciţii şi probleme, clasa a IX-a, Editura Dacia, Cluj-Napoca, 2004

[50] Pop Vasile, Lupşor Viorel şi col.: Matematică pentru grupele de performanţă, clasa a $X$ - $a$, Editura Dacia, Cluj-Napoca, 2003

[51] Pop Vasile, Lupşor Viorel şi col.: Matematică pentru grupele de performanţă. Exerciţii şi probleme, clasa a $X$-a, Editura Dacia, Cluj-Napoca, 2004

[52] Reiman István, Dobos Sándor: Nemzetközi matematikai diákolimpiák 1959-2003, Typotex kiadó, Budapest, 2003

[53] Reiman István: Fejezetek az elemi geometriából, Typotex kiadó, Budapest, 2002

[54] Reiman István: Geometria és határterületei, Szalay Könyvkiadó és Kerereskedőház, Kisújszállás, 1999

[55] Tudor Victor: Probleme de algebră cu rezolvări ingenioase, Editura Carminis, Piteşti, 1999 


\section{Publikációs jegyzék}

\section{A szerző publikációi}

1. Nagy Örs: A reprezentációváltás taníthatóságáról, Polygon, (megjelenés alatt)

2. Nagy Örs, András Sz.: Approximated Poncelet configurations, Teaching Mathematics and Computer Sciences, 13 (2015)

3. András Sz., Nagy Örs: Measuring with unscaled pots - algorithm versus chance, Electronic Journal of Mathematics and Technology, 4 (2010)

4. András Sz., Csapó H., Nagy Örs, Sipos K., Soós A., Szilágyi J.: Kíváncsiságvezérelt matematikatanitás (Primas projekt), Státus Kiadó, Csíkszereda, 2010

5. Kupán P., Bencze M., Nagy Örs, et al.: V. Erdélyi Magyar Matematikaverseny, 5-8. évfolyam, Idea Studio, Szatmárnémeti, 2017

6. András Sz., Csapó H., David G., Nagy Örs, Szilágyi J., Zsombori G.: I. Erdélyi Magyar Általános Iskolák Matematikaversenye, Státus Kiadó, Csíkszereda, 2013

7. András Sz., Bencze M., Csapó H., David G., Nagy Örs, Szilágyi J.: XXIII. Erdélyi Magyar Matematikaverseny, Prolog Kiadó, Nagyvárad, 2013

8. András Sz., Bencze M., Csapó H., Dávid G., Mészáros A., Nagy Örs, Szilágyi J.: XXI. Erdélyi Magyar Matematikaverseny, Státus Kiadó, Csíkszereda, 2011

9. András Sz., Mészáros A., Nagy Örs: XIX. Nemzetközi Magyar Matematikaverseny, Státus Kiadó, Csíkszereda, 2010 


\section{Fontosabb előadások jegyzéke}

1. Kisebb kutatási feladatok a kiváncsiságvezérelt matematikatanitás tükrében Matematika- és informatika didaktikai kutatások konferencia, 2013. január 25-27., Debreceni Egyetem és Párciumi Keresztény Egyetem, Nagyvárad

2. Semmi sem az, aminek látszik - Magyar Tudomány Napja Erdélyben, Matematikadidaktika szekció, 2012. nov. 9-11., Kolozsvár

3. Számitógépes kisérletezés, sejtés és bizonyitás a matematika tanitásában - Magyar Tudomány Napja Erdélyben, Matematikadidaktika szekció, 2011. nov. 4-6., Székelyudvarhely

4. Kíváncsiságvezérelt matematikaoktatás - Új utak és módok az oktatásban, BBTE Neveléstudományi konferencia, 2010. május, Kolozsvár

5. Geometriai struktúrák számitógépes modellezése - Minőségfejlesztés a matematikaoktatásban, BBTE tanártovábbképző, 2009, 2010, 2011. szept., Kolozsvár 